Fernanda Pilati

\title{
Análise dos efeitos da borracha moída de pneu e do resíduo de óleo de xisto sobre algumas propriedades mecânicas de misturas asfálticas densas
}

Dissertação apresentada à Escola de Engenharia de São Carlos da Universidade de São Paulo, como parte dos requisitos para a obtenção do título de Mestre em Engenharia de Transportes.

Orientador: Prof. Dr. Glauco Tulio Pessa Fabbri

São Carlos

2008 
AUTORIZO A REPRODUÇÃO E DIVULGAÇÃO TOTAL OU PARCIAL DESTE TRABALHO, POR QUALQUER MEIO CONVENCIONAL OU ELETRÔNICO, PARA FINS DE ESTUDO E PESQUISA, DESDE QUE CITADA A FONTE.

Ficha catalográfica preparada pela Seção de Tratamento da Informação do Serviço de Biblioteca - EESC/USP

Pilati, Fernanda

P637a Análise dos efeitos da borracha moída de pneu e do resíduo de óleo de xisto sobre algumas propriedades mecânicas de misturas asfálticas densas / Fernanda Pilati ; orientador Glauco Túlio Pessa Fabbri. -- São Carlos, 2008.

Dissertação (Mestrado-Programa de Pós-Graduação em Engenharia de Transportes e Área de Concentração em Planejamento e Operações de Sistemas de Transportes) -- Escola de Engenharia de São Carlos da Universidade de São Paulo, 2008.

1. Alfalto-borracha. 2. Resíduo de óleo de xisto. 3. Processo úmido. 4. Experimentos com misturas. 5. Misturas asfálticas densas. 6. Propriedades mecânicas. I. Título. 
Dedico este trabalho à minha família, Laurindo, Deonila, Emerson, Rubiane, meu cunhado Fabiano, e especialmente, à Thereza Roza. 
"Superação é ter a humildade de aprender com o passado, não se confomar com o presente e desafiar o futuro"

(Hugo Bethlem) 
A Deus, pela sua infinita bondade, amor, incentivo, força e motivação para a realização desse trabalho.

Especialmente à minha família. Meus pais, Deonila e Laurindo, por todo ensinamento, amor, dedicação e apoio durante todos os acontecimentos da minha vida, e, apesar da distância, foram incansáveis e inigualáveis no apoio e compreensão. Aos meus irmãos, Emerson e Rubiane, por todo incentivo, paciência e amizade sincera.

Ao meu namorado Vinicius pelo seu amor, apoio, companheirismo, dedicação, compreensão, e principalmente, paciência durante todo esse período.

Agradeço ao professor Dr. Glauco pelo seu apoio, dedicação, competência e sua indispensável e valorosa orientação.

A Adalberto Leandro Faxina por toda dedicação, paciência e ajuda para realização deste trabalho.

Aos meus amigos, Wyvianne Rech, Paula Pulga, Eduardo Spigiorin, Patrícia Santos, Lidiane Francine, Débora Soares, Jandiana Lucof, Alexandra Urnau, Aleksandro Rocha, Taciana Rysma, Mário Neto, Priscila Oliveira, Derby Neto, Michele Fragoso, Rodolfo Sanches, Antônio Carlos de Souza, Marcus Alexandre, João Uchoa, Wellington Andrade, Régis Pamponet, Liris Campelo, Carolina Mello, Jaqueline Feitoza que mesmo distante me apoiaram e incentivaram durante essa fase. Agradeço de coração todo companheirismo e amizade dedicados a mim.

Aos amigos conquistados durante esse período, Josiele Patias, Paulo Hanke, Leonardo Carnielle, Mara Carvalho, pela amizade, apoio, ajuda, e principalmente pelos bons momentos vividos durante essa época. 
Aos técnicos de laboratório, Paulo Toyama, em especial, Antônio Carlos Gigante e João Pereira pela disponibilidade, dedicação e ajuda durante toda pesquisa.

Aos engenheiros do DER/PR Gilberto Borborema e Léo Albuquerque por todos os ensinamentos e incentivo para a realização do mestrado.

Aos professores do Departamento de Transportes da EESC-USP pelos ensinamentos e apoio constante.

Aos funcionários do Departamento de Transportes da EESC-USP, em especial, à Antonia Magali M. César por todo apoio e amizade durante esse período.

À Fundação de Ampara a Pesquisa do Estado de São Paulo, pelo auxílio à pesquisa (processo $n^{\circ}$ 04/09761-5), coordenado pelo Prof. Dr. Manoel Henrique Alba Sória, que proporcionou a instalação de alguns equipamentos de laboratório utilizados nesta pesquisa.

À CAPES, pela concessão da bolsa de mestrado. 
PILATI, Fernanda (2008). Análise dos efeitos da borracha moída de pneu e do resíduo de óleo de xisto sobre algumas propriedades mecânicas de misturas asfálticas densas. 210p. Dissertação (Mestrado) - Escola de Engenharia de São Carlos, Universidade de São Paulo, São Carlos, 2008.

No Brasil, desde o início da década de 1990, vêm sendo desenvolvidas pesquisas sobre aplicação do asfalto-borracha visando tanto a diminuição dos problemas ambientais gerados pelo descarte de pneus inservíveis, como a melhoria das características dos ligantes produzidos. Esta pesquisa teve por objetivo avaliar o desempenho mecânico de oito misturas asfálticas do tipo concreto asfáltico usinado a quente, produzidas com asfaltos convencional e convencional modificado com borracha de pneu e resíduo de óleo de xisto. Quanto ao ligante, foram utilizados 8 tipos, a saber: CAP 30/45 (referência); dois ligantes empregando teores diferentes de borracha moída de pneu; outros dois com teores distintos de resíduo de óleo de xisto e, por fim, mais três com combinações de teores de borracha e de resíduo de óleo de xisto. Os corpos-de-prova empregados nos ensaios foram moldados em cinco teores diferentes de ligantes asfálticos $(4,5 ; 5,0,5,5 ; 6,0$ e 6,5\%). Foram realizados ensaios Marshall, resistência à tração, módulo de resiliência e umidade induzida. Com base nos resultados dos ensaios realizados, observou-se que tanto a borracha quanto o óleo reduzem a resistência à tração e o módulo de resiliência das misturas, no entanto, na recuperação retardada, os efeitos da borracha e do óleo são antagônicos, diminuindo e aumentando, respectivamente. Quanto à suscetibilidade à ação da água, as misturas com adição de óleo apresentaram menor suscetibilidade que as misturas com adição de borracha. Todas as misturas estudadas, exceto aquelas com altas concentrações de óleo e de borracha, conseguiram atender os requisitos estabelecidos pelas especificações, para as propriedades analisadas. Todavia, em alguns casos, considerando os efeitos antagônicos do óleo e da borracha, algumas combinações entre ambos podem ser realizadas, com a finalidade de alcançar os níveis desejados para as propriedades do ligante asfalto-borracha e das misturas asfálticas.

Palavras-chave: asfalto-borracha, óleo de xisto, processo úmido, experimentos com misturas, misturas asfálticas densas, propriedade mecânicas. 
PILATI, Fernanda (2008). Analysis of the effects of crumb rubber and shale-oil residue on mechanical properties of asphalt mixtures. 210p. Master thesis (Mastering) - Escola de Engenharia de São Carlos, Universidade de São Paulo, São Carlos, 2008.

In Brazil, since the beginning of the 90's, have been developed researches on the application of asphalt-rubber seeking the reduction of environmental problems created by the used tires, and the improvement of the characteristics of the produced binder. The purpose of this research is to evaluate the mechanical performance of eight hot mix asphalt concretes, produced with conventional asphalt and modified asphalt with crumb rubber and shale-oil residue Eight types of binders were used: CAP 30/45 (reference); two binders using different crumb rubber contents, two with different shale-oil residue contents, and finally three more with the combination of crumb rubber and shale-oil residue contents. The specimens used in the laboratorial tests were compacted in five different binders contents $(4.5 ; 5.0,5.5 ; 6.0 \mathrm{e}$ 6.5\%). The tests performed are: Marshall test, indirect tension, resilient modulus and moisture induced. The results showed that the rubber and the shale oil reduce the indirect tension and resilience module of the mixtures, however, on the delayed recover, the effects of the rubber and of the shale oil are opposed, decreasing and increasing it, respectively. For the moisture susceptibility, the mixtures with shale-oil residue exhibited less susceptibility to water than those with crumb rubber. All the studied mixtures, except those with high shale-oil residue and rubber concentrations, they got to attend the established requirements for the specifications, for the analyzed properties. Although, in some cases, considering the opposed effects of the shale oil and of the crumb rubber, some combinations between both can be accomplished, with the purpose of reach the levels wanted for the properties of the asphaltrubber binder and the asphalt mixtures.

Key words: crumb-rubber, shale-oil residue, wet process, experiments with mixtures, hot mix asphalt, mechanical properties. 


\section{LISTA DE F IGURAS}

Figura 2.1: Ensaio de tração indireta em amostra cilíndrica. 31

Figura 2.2. Curva de deformação x tempo, para um ciclo de carregamento............................ 34

Figura 2.3. Curva de deformação para um ciclo de carregamento (NCHRP).......................... 35

Figura 3.1: Simplex formado pelos três componentes e espaço amostral com restrições........ 41

Figura 3.2. Espaço amostral com restrições e misturas escolhidas. ......................................... 42

Figura 3.3. Faixa C do DER/SP (DER/SP, 1991) e curva granulométrica da mistura obtida..45

Figura 3.4. Curva granulométrica da borracha moída............................................................ 49

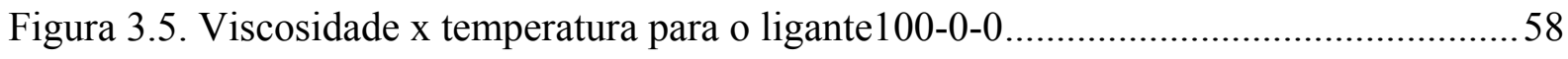

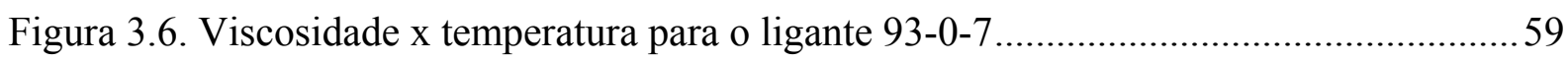

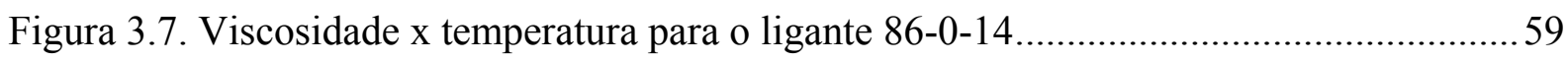

Figura 3.8. Equipamento adaptado para o procedimento de mistura .....................................62

Figura 3.9. Equipamento utilizado para ensaio de módulo de resiliência ..............................65

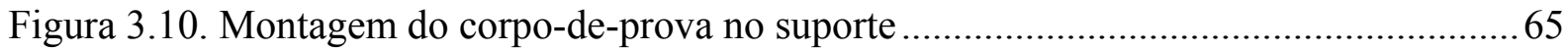

Figura 3.11. Prensa utilizada nos ensaios de estabilidade Marshall e resistência à tração.......67

Figura 3.12. Textura superficial do topo do corpo-de-prova (a)não condicionado e

(b)condicionado. 68

Figura 3.13. Textura superficial do corpo-de-prova (a)não condicionado e (b)condicionado. 68

Figura 4.1: Estabilidade das misturas asfálticas: (a) adição de óleo e (b) adição de borracha. 73

Figura 4.2: Estabilidade das misturas asfálticas com adição de óleo e borracha. .................... 74

Figura 4.3: Fluência das misturas asfálticas: (a) adição de óleo e (b) adição de borracha....... 75

Figura 4.4: Fluência das misturas asfálticas com adição de óleo e borracha. .......................... 76

Figura 4.5 Módulo de resiliência total das misturas: (a) adição de óleo e (b) adição de

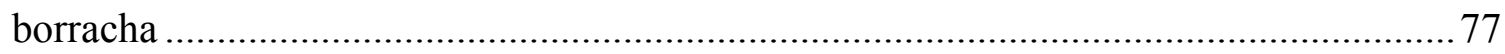

Figura 4.6 Módulo de resiliência total das misturas com adição de óleo e borracha ...............78

Figura 4.7 Resistência à tração das misturas: (a) adição de óleo e (b) adição de borracha...... 79

Figura 4.8 Resistência à tração das misturas com adição de óleo e borracha ...........................80

Figura 4.9 Relação MR/RT das misturas: (a) adição de óleo e (b) adição de borracha ............81

Figura 4.10 Relação MR/RT das misturas: com adição de óleo e borracha..............................82

Figura 4.11 Recuperação retardada das misturas: (a) adição de óleo e (b) adição de borracha83 
Figura 4.12 Recuperação retardada das misturas com adição de óleo e borracha ................... 84

Figura 4.13 MRt das misturas condicionadas e não-condicionadas: (a) adição de óleo e....... 85

(b) adição de borracha

Figura 4.14 MRt das misturas condicionadas e não-condicionadas com adição de óleo e borracha 86

Figura 4.15 Relação de módulo de resiliência (RMR) das misturas estudadas 87

Figura 4.16 Resistência à tração das misturas condicionadas e não condicionadas: (a) adição de óleo e (b) adição de borracha 88

Figura 4.17 Resistência à tração das misturas condicionadas e não condicionadas com adição de óleo e borracha 89

Figura 4.18 Relação de resistência à tração (RRT) das misturas asfálticas estudadas 89

Figura 4.19 Recuperação retardada das misturas condicionadas e não condicionadas: (a) adição de óleo e (b) adição de borracha 90

Figura 4.20 Recuperação retardada das misturas condicionadas e não condicionadas com adição de óleo e borracha. 91

Figura 4.21: Superfície de resposta (a) e efeitos dos componentes (b) para densidade aparente 95

Figura 4.22: Superfície de resposta (a) e efeitos dos componentes (b) para o volume de vazios 96

Figura 4.23: Superfície de resposta (a) e efeitos dos componentes (b) para o VAM 97

Figura 4.24: Superfície de resposta (a) e efeitos dos componentes (b) para RBV ................. 97

Figura 4.25: Superfície de resposta (a) e efeitos dos componentes (b) para fluência.............. 98

Figura 4.26: Superfície de resposta (a) e efeitos dos componentes (b) para estabilidade........ 99

Figura 4.27: Superfície de resposta (a) e efeitos dos componentes (b) para MRt NCHRP ... 100

Figura 4.28: Superfície de resposta (a) e efeitos dos componentes (b) para RT.................... 101

Figura 4.29: Superfície de resposta (a) e efeitos dos componentes (b) para MRt/RT ........... 102

Figura 4.30: Superfície de resposta (a) e efeitos dos componentes (b) para RR ................... 103

Figura 4.31: Superfície de resposta (a) e efeitos dos componentes (b) para MRt NCHRP condicionado

Figura 4.32: Superfície de resposta (a) e efeitos dos componentes (b) para RT condicionada

Figura 4.33: Superfície de resposta (a) e efeitos dos componentes (b) para MRt/RT condicionada 
Figura 4.34: Superfície de resposta (a) e efeitos dos componentes (b) para RR condicionada 107

Figura 4.35: Superfície de resposta (a) e efeitos dos componentes (b) para relação RMR .... 107 Figura 4.36: Superfície de resposta (a) e efeitos dos componentes (b) para relação RMR .... 108 Figura A1: Parâmetros Marshall para mistura 100-0-0 ........................................................ 129

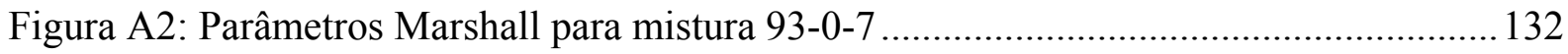

Figura A3: Parâmetros Marshall para mistura 86-0-14 _........................................................... 135

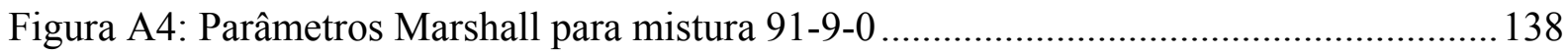

Figura A5: Parâmetros Marshall para mistura 77-9-14 ........................................................ 141

Figura A6: Parâmetros Marshall para mistura 82-18-0 ......................................................... 144

Figura A7: Parâmetros Marshall para mistura 75-18-7 ..................................................... 147

Figura A8: Parâmetros Marshall para mistura 68-18-14 ..................................................... 150 


\section{LISTA DE TABELAS}

Tabela 2.1: Exigências da norma ES-P 28/05 do DER/PR para asfalto-borracha em camadas

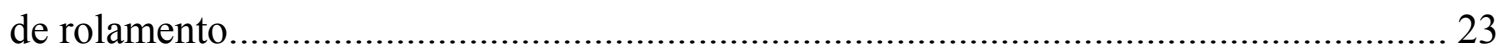

Tabela 2.2: Diferenças apresentadas pelas especificações de asfalto-borracha....................... 24

Tabela 3.1. Proporções dos componentes das misturas selecionadas. ..................................... 42

Tabela 3.2. Propriedades físicas, temperaturas e métodos de ensaio, para os ligantes asfálticos

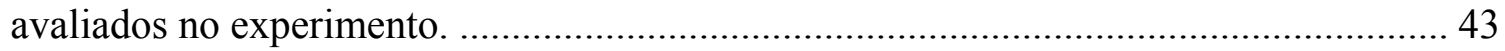

Tabela 3.3. Propriedades mecânicas das misturas asfálticas avaliadas no experimento.......... 44

Tabela 3.4. Limites da faixa "C" do DER/SP e composição granulométrica da mistura final 44

Tabela 3.5. Ensaios de caracterização física dos agregados minerais. .................................... 48

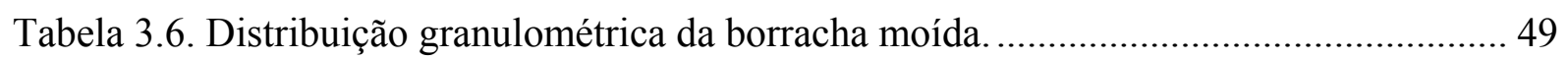

Tabela 3.7. Caracterização do agente rejuvenescedor de xisto AR-5 .................................... 50

Tabela 3.8. Resultados de caracterização física do CAP 30/45 ............................................... 51

Tabela 3.9. Resultados de caracterização física do Ligante 2 (93-0-7). ................................. 52

Tabela 3.10. Resultados de caracterização física do Ligante 3 (86-0-14) .............................. 52

Tabela 3.11. Resultados de caracterização física do Ligante 4 (91-9-0). ................................ 53

Tabela 3.12. Resultados de caracterização física do Ligante 5 (77-9-14). ............................. 53

Tabela 3.13. Resultados de caracterização física do Ligante 6 (82-18-0). ............................. 54

Tabela 3.14. Resultados de caracterização física do Ligante 7 (75-18-7). .............................. 54

Tabela 3.15. Resultados de caracterização física do Ligante 8 (68-18-14)............................ 55

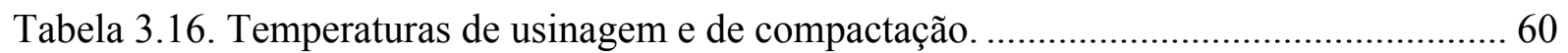

Tabela 3.17. Densidades efetivas dos agregados e densidades dos ligantes asfálticos............ 62

Tabela 3.18. Quantidade de corpos-de-prova ensaiados por mistura estudada ...................... 64

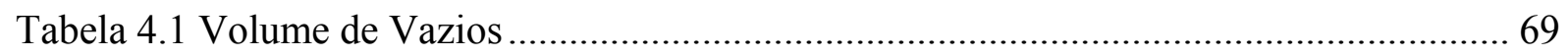

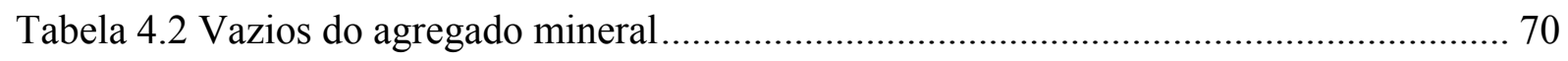

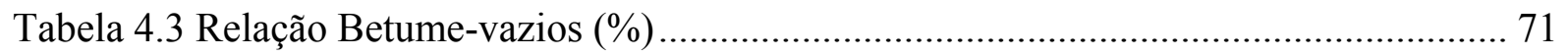

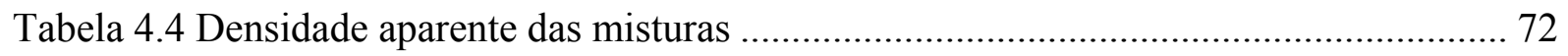

Tabela 4.5: Modelos de regressão referente às propriedades monitoradas............................ 99

Tabela 4.6: Modelos de regressão referente às propriedades monitoradas............................ 103

Tabela 4.7 Modelos de regressão referentes às propriedades das misturas condicionadas ... 109 
Tabela A1: Parâmetros Marshall para mistura 100-0-0. 127

Tabela A2: Parâmetros Marshall para mistura 93-0-7 ........................................................... 130

Tabela A3: Parâmetros Marshall para mistura 86-0-14........................................................ 133

Tabela A4: Parâmetros Marshall para mistura 91-9-0.......................................................... 136

Tabela A5: Parâmetros Marshall para mistura 77-9-14........................................................ 139

Tabela A6: Parâmetros Marshall para mistura 82-18-0........................................................ 142

Tabela A7: Parâmetros Marshall para mistura 75-18-7 ....................................................... 145

Tabela A8: Parâmetros Marshall para mistura 68-18-14 ....................................................... 148

Tabela B1: Estabilidade e Fluência Marshall para mistura .................................................... 152

Tabela C1: Módulo de Resiliência das misturas no teor de 4,5\% ........................................ 155

Tabela C2: Módulo de Resiliência das misturas no teor de 5,0\% ....................................... 157

Tabela C3: Módulo de Resiliência das misturas no teor de 5,5\% ...................................... 159

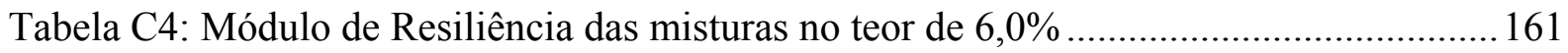

Tabela C5: Módulo de Resiliência das misturas no teor de 6,5\% ....................................... 163

Tabela D1: Resistência à tração das misturas estudas......................................................... 166

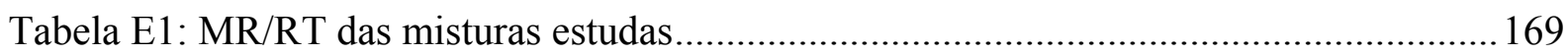

Tabela F1: Recuperação Retardada das misturas estudas ................................................. 175

Tabela G1: Módulo de Resiliência condicionados das misturas estudadas............................ 181

Tabela G2: Relação dos módulos de resiliência das misturas estudadas .............................. 183

Tabela G3: Resistência à tração condicionada das misturas estudadas................................... 186

Tabela G3: Relação da resistência à tração condicionada das misturas estudadas ................. 189 


\section{Lista de Abreviatura, Siglas e Símbolos}

AASHTO Americam Association of State Highway and Transportation Officials

ABNT Associação Brasileira de Normas Técnicas

ADOT Arizona Departament of Transportation

ANIP Associação Nacional das Indústrias de Pneumáticos

AR-5 Classificação do agente rejuvenescedor (segundo ASTM D4552/86)

ARTESP Agência de Transportes do Estado de São Paulo

ASTM American Society of Testing Materials

BMP Borracha moída de pneu

BRP Borracha reciclada de pneu

CAP Cimento asfáltico de petroléo

CBUQ Concreto betuminoso usinado a quente

CENPES Centro de pesquisa da Petrobras

CNT Confederação Nqqacional de Transportes

CONAMA Conselho Nacional do Meio Ambiente

DEINFRA Departamento Estadual de Infra-estrutura de Santa Catarina

DER-PR Departamento de Estradas de Rodagem do Estado do Paraná

DER-SP Departamento de Estradas de Rodagem do Estado de São Paulo

DNER-ME Método de ensaio do Departamento Nacional de Estradas de Rodagem

EVA ethylene vinyl acetate (polímero)

LVDT linear variable differential transformer

NCHRP National Cooperative Highway Research Program

RTFOT Rolling Thin Film Oven Test

SBR styrene-butadiene-rubber (polímero)

SBS styrene-butadiene-styrene (polímero)

SIX Superintendência da Industrialização do Xisto - Petrobras

SMA Stone Matrix Asphalt

PAV Pressure aging vessel

PG Performance grade

VGC Viscosity-gravity constant

CPA Camada porosa de atrito 


\begin{tabular}{|c|c|}
\hline $\mathrm{CP}$ & Corpo-de-prova \\
\hline $\mathrm{RT}$ & Resistência à tração \\
\hline$\sigma_{\mathrm{t}}$ & Tensão de tração \\
\hline$\sigma_{\mathrm{adm}}$ & Tensaõ de tração admissível \\
\hline $\mathrm{h}$ & Altura do corpo-de-prova \\
\hline $\mathrm{d}$ & Diâmetro do corpo-de-prova \\
\hline MR & Módulo de resiliência \\
\hline $\mathrm{MR}_{\mathrm{t}}$ & Módulo de resiliência total \\
\hline $\mathrm{MR}_{\mathrm{i}}$ & Módulo de resiliência instantâneo \\
\hline $\mathrm{F}$ & Carga aplicada \\
\hline$\Delta$ & deslocamento \\
\hline$\Delta_{\mathrm{t}}$ & Deslocamento total \\
\hline$\Delta_{\mathrm{i}}$ & Deslocamento instantâneo \\
\hline$\mu$ & Coeficiente de poisson \\
\hline RR & Recuperação retardada \\
\hline$\varepsilon_{\mathrm{t}}$ & Deformação total \\
\hline$\varepsilon_{\mathrm{i}}$ & Deformação instantânea \\
\hline RRT & Relação da resistência à tração \\
\hline $\mathrm{RT}_{1}$ & Resistência à tração média do grupo condicionado \\
\hline $\mathrm{RT}_{2}$ & Resistência à tração média do grupo de controle \\
\hline An & Abrasão Los Angeles \\
\hline $\mathrm{V}$ & Viscosidade Saybol-Furol \\
\hline DMM & Densidade máxima teórica \\
\hline $\mathrm{Pb}$ & Teor de asfalto \\
\hline$\rho_{\text {ef }}$ & Densidade efetiva do agregado \\
\hline$\rho_{\mathrm{ap}}$ & Densidade aparente do agregado \\
\hline$\rho_{\mathrm{ag}}$ & Densidade da porção pétrea da mistura \\
\hline $\mathrm{Abs}_{\mathrm{asf}}$ & Absorção de asfalto \\
\hline $\mathrm{E}$ & estabilidade \\
\hline $\mathrm{F}$ & Fluência \\
\hline $\mathrm{D}_{\mathrm{ap}}$ & Densidade aparente da mistura \\
\hline Vv & Volume de vazios \\
\hline RBV & Relação betume-vazios \\
\hline VAM & Vazios do agregado mineral \\
\hline
\end{tabular}


RESUMO

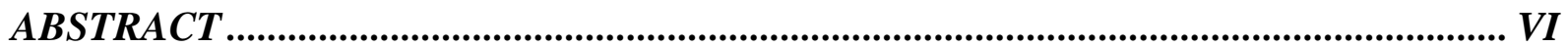

LISTA DE FIGURAS .............................................................................................................. vii

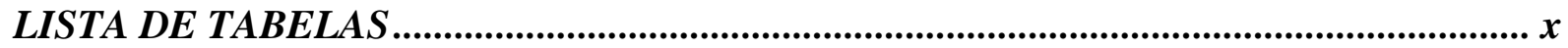

LISTA DE ABREVIATURA, SIGLAS E SÍMBOLOS ................................................. xii

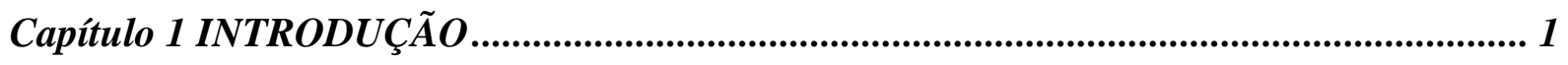

Capítulo 2 REFERENCIAL TEÓRICO ............................................................................... 5

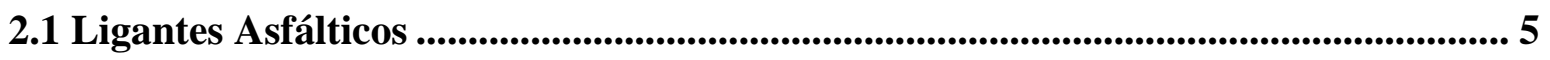

2.1.1 Constituição química do asfalto ................................................................... 7

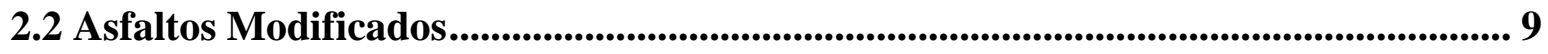

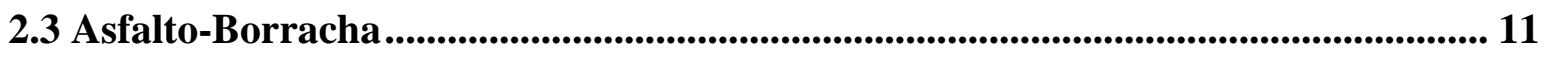

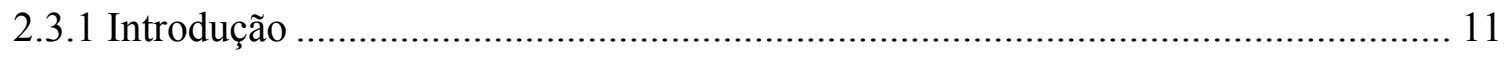

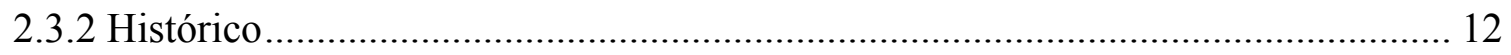

2.3.3 Método de Obtenção do Asfalto-Borracha .............................................................. 16

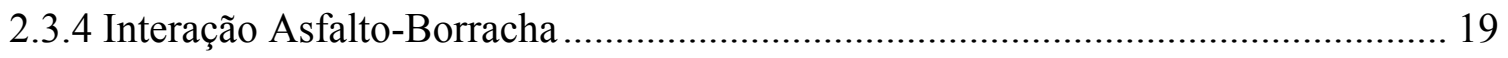

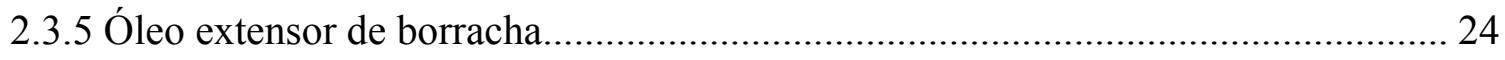

2.4 Misturas Asfálticas................................................................................................ 25

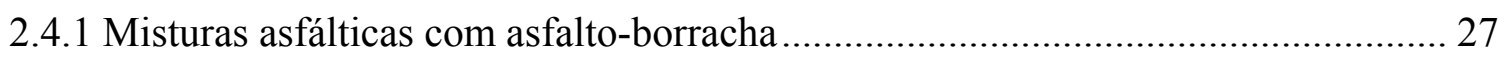

2.4.1.2 Propriedades das misturas com asfalto-borracha .......................................... 28

2.5 Ensaios de Propriedades Mecânicas.................................................................................... 30

2.5.1 Ensaio de Resistência à Tração por compressão diametral...................................... 31

2.5.2 Módulo de Resiliência por compressão diametral dinâmica ................................... 32

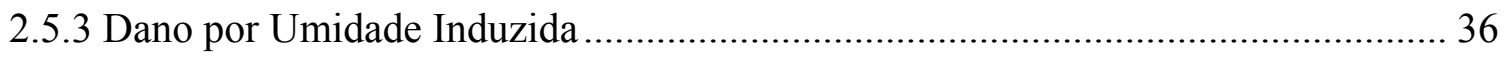

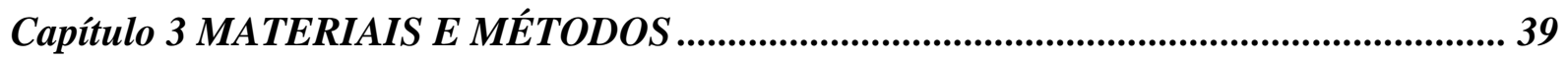

3.1. Planejamento do experimento.................................................................................... 39 
3.2 Materiais Utilizados..............................................................................................................4

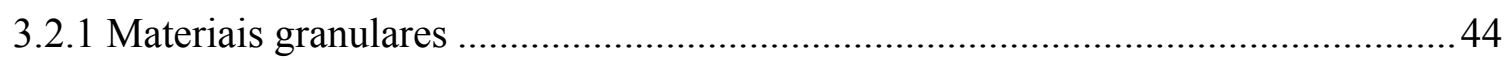

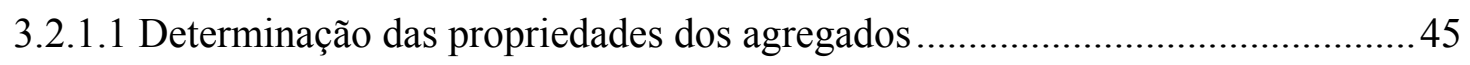

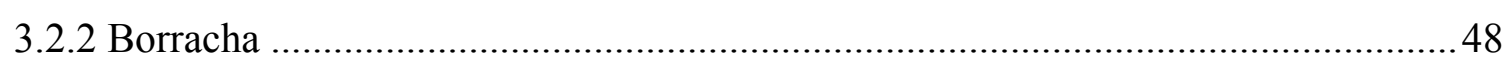

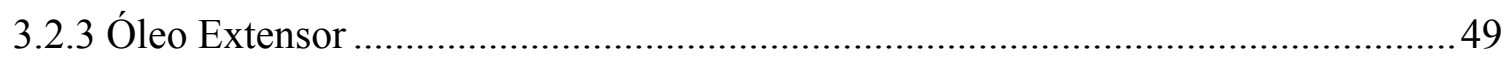

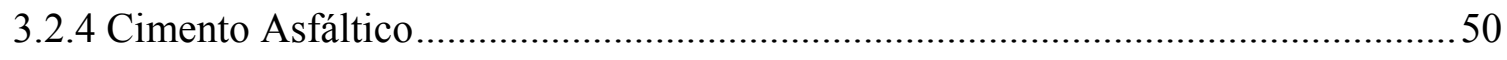

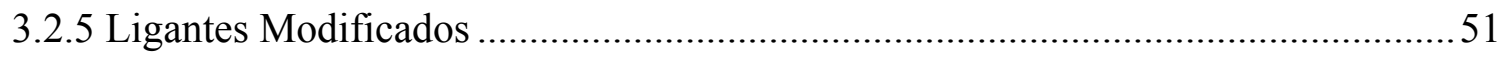

3.3 Procedimentos e Equipamentos de Laboratório..................................................55

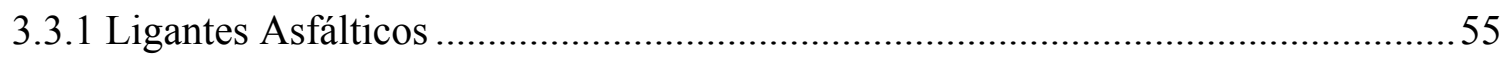

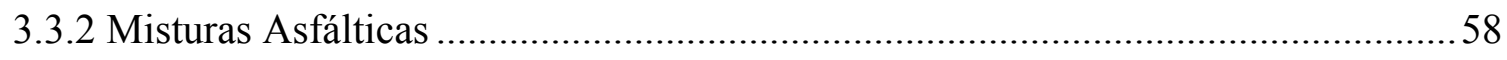

3.3.2.1 Temperaturas de usinagem e de compactação................................................5 58

3.3.2.2 Determinação da Densidade Máxima Teórica de Misturas Asfálticas

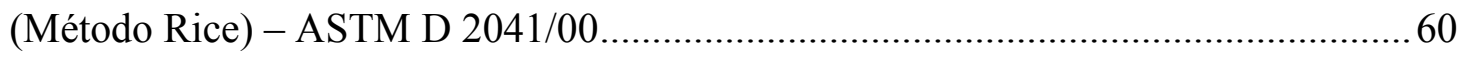

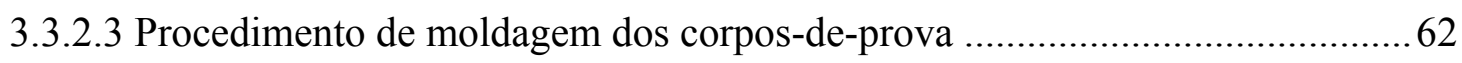

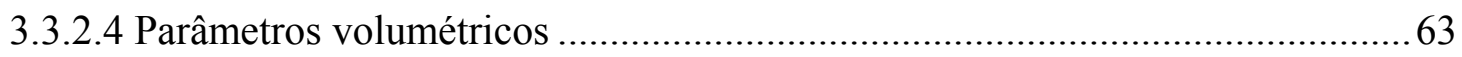

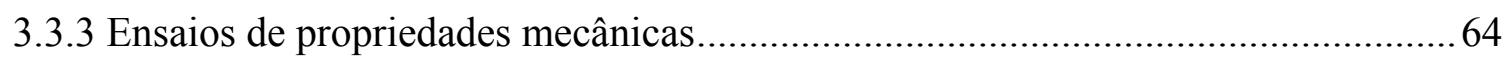

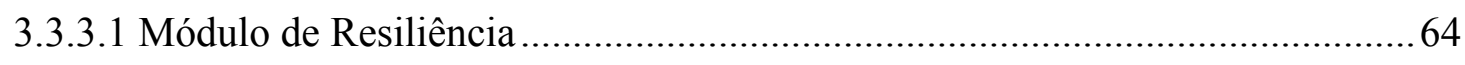

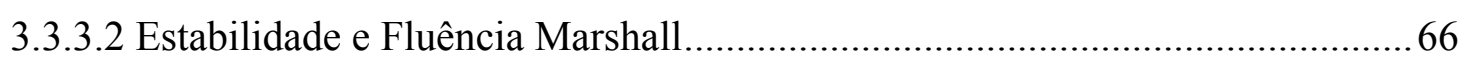

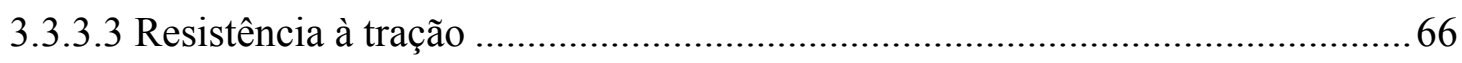

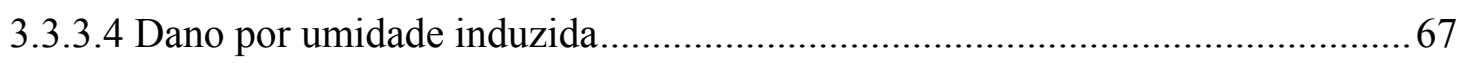

Capítulo 4 APRESENTAÇÃO E ANÁLISE DOS RESULTADOS.................................69

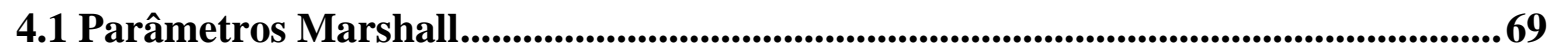

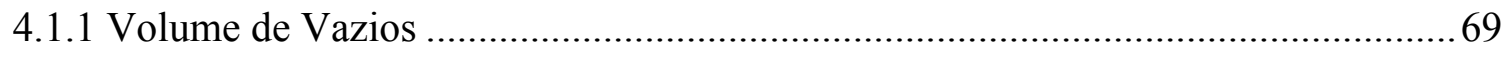

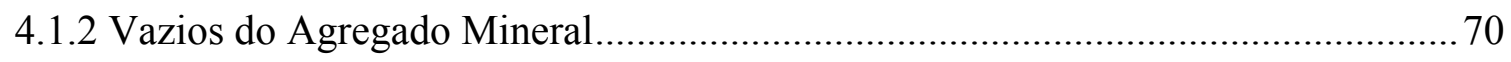

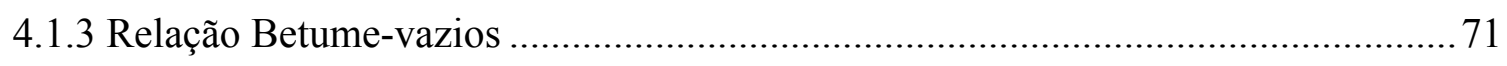

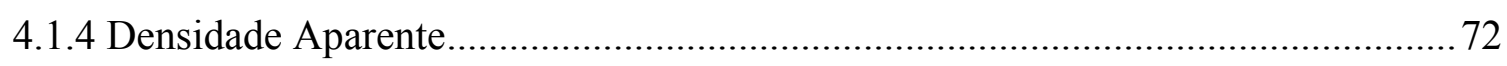

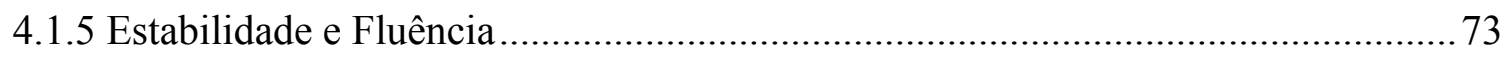

4.2 Ensaios das Propriedades Mecânicas .....................................................................76

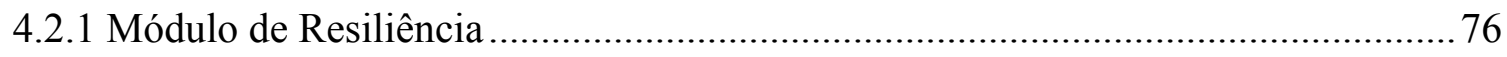

4.2.3 Resistência à Tração por compressão diametral .................................................... 79

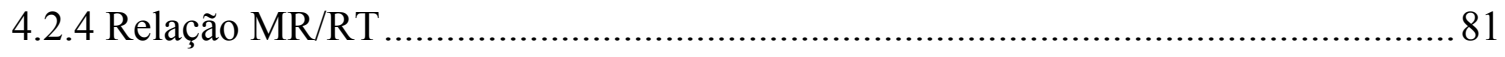

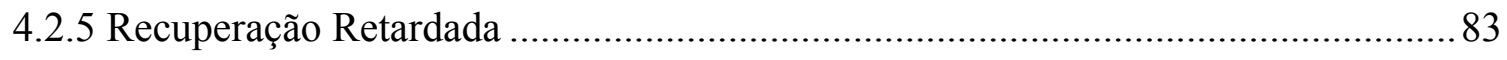




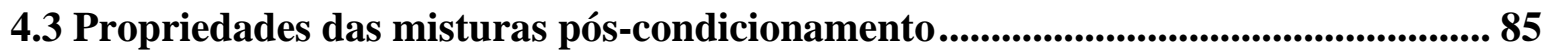

4.3.1 Módulo de Resiliência pós-condicionamento …................................................... 85

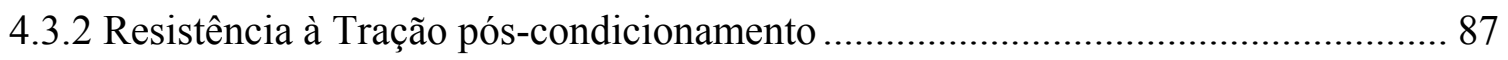

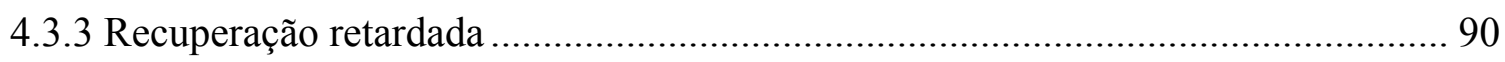

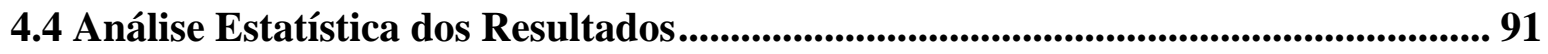

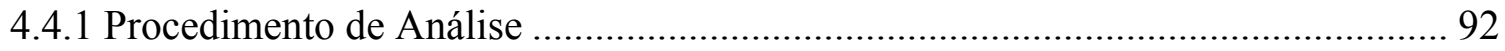

4.5 Análise estatística das propriedades das misturas asfálticas não condicionadas... 94

4.5.1 Superfície de Resposta e Efeito de componentes.................................................. 95

4.5.1.1 Parâmetros volumétricos, estabilidade e fluência ........................................... 95

4.5.1.2 Módulo de Resiliência não-condicionado.................................................... 100

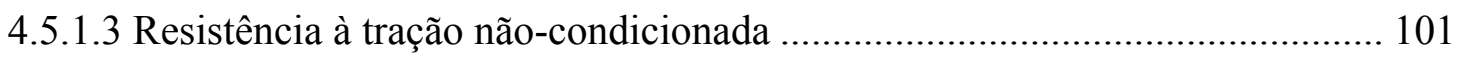

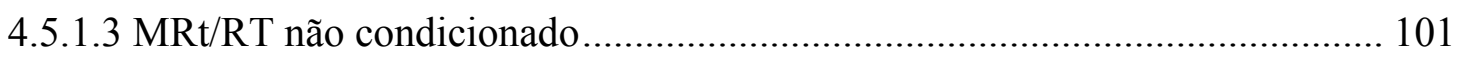

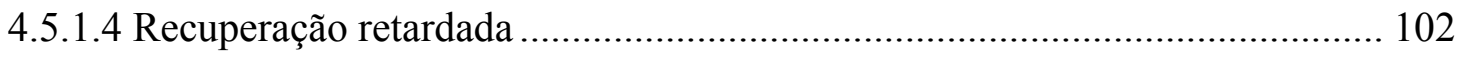

4.6 Análise estatística das propriedades das misturas asfálticas condicionadas ........ 104

4.6.1.1 Módulo de Resiliência condicionado................................................................ 104

4.6.1.2 Resistência à tração condicionada................................................................... 105

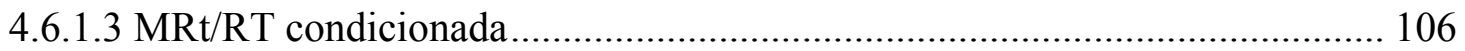

4.6.1.4 Recuperação retardada condicionada.......................................................... 106

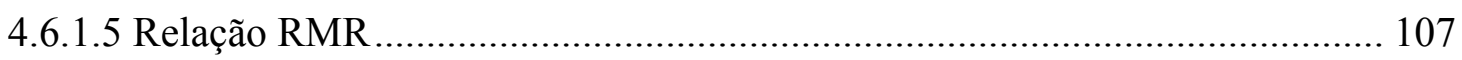

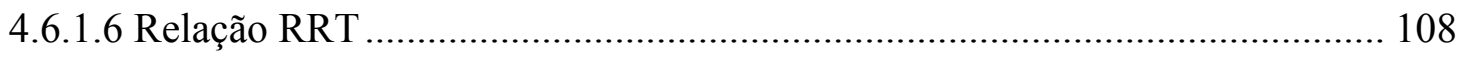

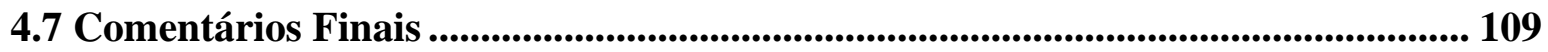

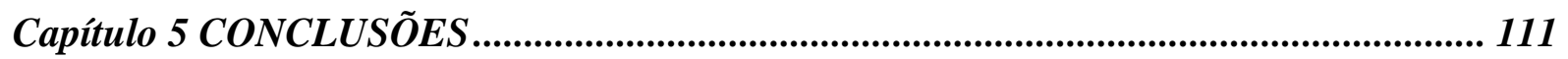

5.1 Parâmetros Marshall ................................................................................................. 111

5.2 Propriedades Mecânicas (misturas não condicionadas).......................................... 112

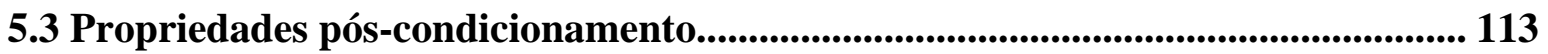

5.4 Conclusões obtidas da análise de superfícies de resposta................................... 113

5.5 Conclusões obtidas da análise de efeito dos componentes...................................... 114

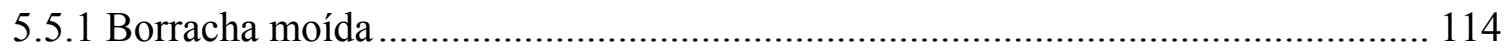

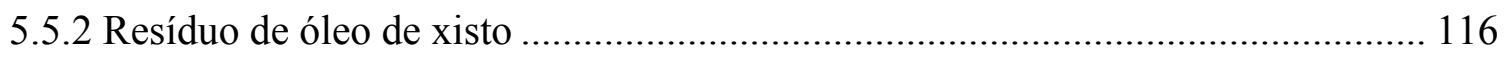

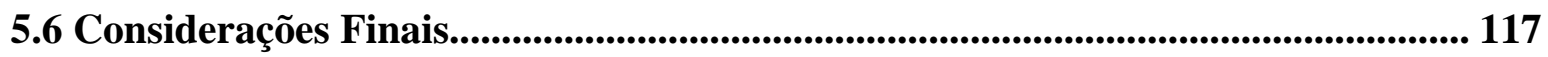




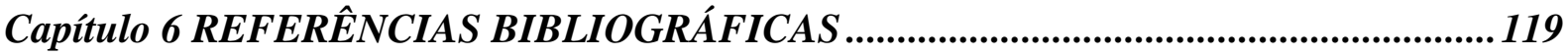

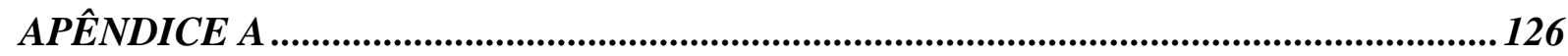

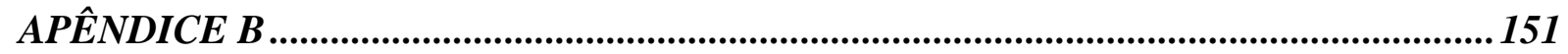

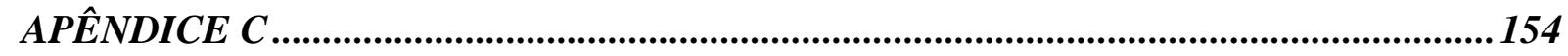

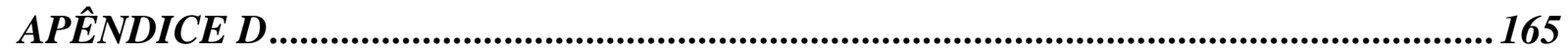

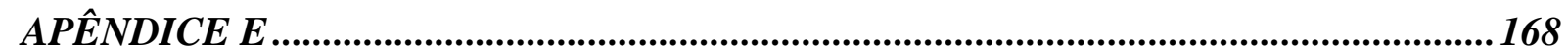

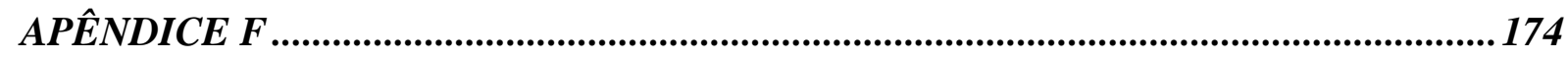

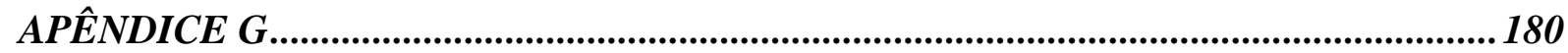





\section{Capitulo 1}

INTRODUÇÃO

O transporte rodoviário é, sem dúvida, vital para o bem-estar econômico e social da população, possuindo papel fundamental tanto no transporte de passageiros, como no transporte de cargas. O principal meio de transporte brasileiro é o rodoviário, sendo a maior parte das rodovias pavimentadas compostas de pavimentos flexíveis com revestimento asfáltico. No entanto, a maior parte das rodovias brasileiras se encontra em péssimo estado de conservação, sendo dessa maneira, muitas vezes, incapazes de oferecer segurança e conforto adequados aos usuários. A ampliação e conservação das rodovias proporcionam um aumento de segurança e de maior economia nos transportes, além de ser uma das principais condições para o desenvolvimento do País.

A análise sistêmica de estudos realizados pela CNT (2007) aponta um quadro geral deficiente para rodovias brasileiras, isto pode ser atribuído a diversos fatores além do revestimento asfáltico em si, como a falta de manutenção, sobrecarga de caminhões, falta de drenagem adequada, materiais sem a qualidade desejada, geometria, má sinalização e execução, entre outros. Vale ressaltar que todo pavimento é projetado para uma determinada vida útil e é natural que durante e após este período sejam realizadas intervenções, buscando-se aumentar a durabilidade do revestimento e do pavimento.

O crescimento da frota circulante de veículos com maior capacidade de carga, maior tração e maior pressão de inflação dos pneus, aliado ao excesso de carga e ao maior espaçamento entre as intervenções de conservação e restauração, contribuem para a deterioração das estradas do País. Todos estes fatos preocupam os técnicos rodoviários, tendo em vista os efeitos das tensões transmitidas aos pavimentos e o número crescente de solicitações, o que tem levado alguns pavimentos a um fracasso precoce. 
$\mathrm{O}$ aumento das cargas aplicadas nas rodovias e a heterogeneidade dos ligantes asfálticos induzem a refletir sobre como melhorar o comportamento mecânico das misturas asfálticas produzidas no País. Essa análise deve levar em conta os danos causados pelo envelhecimento do ligante, pelas cargas solicitantes e pelas ações do meio ambiente. Atualmente, tem-se buscado materiais com melhores características para possibilitar essa melhoria.

Os ligantes asfálticos com adição de modificadores apresentam propriedades físicas, mecânicas e químicas melhoradas em relação aos cimentos asfálticos convencionais, proporcionando o aumento da durabilidade e da resistência ao aparecimento de defeitos. São adicionados aos cimentos asfálticos produtos como agentes melhoradores de adesividade, agentes rejuvenescedores, polímeros (SBR, SBS, EVA, etc), e também borracha de pneu moída.

O pneu possui papel fundamental e insubstituível tanto no transporte de passageiros quanto no de cargas. No entanto, quando se tornam inservíveis, acarretam uma série de problemas sanitários e ambientais. Uma das maneiras de minimizar este problema é a adição de sua borracha triturada em misturas asfálticas, a qual melhora o desempenho dos pavimentos, retardando o aparecimento de trincas e diminuindo os custos operacionais (DANTAS NETO, 2004).

Para os mais de 56 milhões de pneus vendidos no Brasil em 2005, somente 27 milhões foram reaproveitados, conforme dados da Associação Nacional de Indústria dos Pneumáticos (ANIP) (LOIOLA, 2006). Devido às crescentes preocupações ambientais, tem-se questionado a respeito da destinação ou deposição final de pneus inservíveis. O reaproveitamento destes pneus se constitui, em todo o mundo, em um desafio muito difícil dado as suas peculiaridades de durabilidade (aproximadamente 600 anos), quantidade, volume e peso e, principalmente, grande dificuldade de propiciar a eles uma nova destinação ecológica e economicamente viável (MORILHA JR. e GRECA, 2003).

O asfalto-borracha é visto como uma alternativa econômica e ecologicamente viável para o estado precário das nossas estradas. A incorporação de borracha no ligante asfáltico é vista como uma excelente alternativa para proporcionar um destino útil às montanhas de pneus inservíveis dispostas em locais inadequados. No Brasil, são colocados no mercado aproximadamente 61 milhões de pneus por ano, sendo que, pelo menos, $50 \%$ dos pneus 
produzidos anualmente estão sendo descartados e dispostos em locais inadequados. Estima-se que o passivo ambiental seja superior a 100 milhões de pneus (ANIP, 2007).

No sentido de amenizar os impactos ambientais foi aprovada em 26 de agosto de 1999 a Resolução no 256 do CONAMA (Conselho Nacional do Meio Ambiente), que determina que produtores e fabricantes sejam responsáveis pelo destino dos pneus descartados. Portanto, produtores e importadores de pneus deverão coletá-los e colocá-los em locais ambientalmente adequados. Pode-se considerar que o destino mais adequado em termos ecológico e ambientalmente correto é aquele que possa gerar um produto comercializável e útil para a sociedade. Uma das alternativas para os resíduos provenientes da borracha de pneu é a sua incorporação ao asfalto convencional, criando um novo tipo de asfalto para pavimentação. Portanto, essa alternativa motiva o estudo e o interesse no desenvolvimento de pesquisas visando à reutilização de borracha de pneus em obras de engenharia.

No intuito de melhorar as propriedades mecânicas das misturas asfálticas, bem como reduzir o passivo ambiental causado pela crescente deposição inadequada de pneumáticos na natureza, muitos países vêm desenvolvendo tecnologia para a incorporação de borracha moída de pneu, BMP, em revestimentos asfálticos. Segundo ODA (2000), as primeiras experiências da incorporação da borracha moída às misturas asfálticas foram feitas nos Estados Unidos, na década de 1960, e desde então, vários estudos foram desenvolvidos naquele país e em outras partes do mundo. No Brasil, algumas universidades e centros de pesquisas começaram seus estudos na década de 1990 (FAXINA, 2002).

Os diversos estudos sobre essa adição vêm apontando inúmeros benefícios à mistura, dentre os quais podem ser citados a redução do envelhecimento, maior flexibilidade, maior resistência às deformações e trincas, redução do ruído, e maior resistência às variações de temperatura, além de redução dos custos com atividades de manutenção e reabilitação. Apresenta também melhores resultados referentes à resistência à fadiga e ao envelhecimento quando comparado aos asfaltos convencionais (SOUSA et al, 2000).

Para Campos et al. (2000), a utilização do asfalto-borracha é uma alternativa altamente competitiva em temos técnicos e econômicos, possibilitando que o país realize uma verdadeira política ambiental devido à reciclagem dos pneus usados, com sua reutilização na 
pavimentação e restauração de estradas, e ao mesmo tempo, reduzindo a utilização de recursos minerais tais como agregados empregados na pavimentação de estradas.

A reação entre a borracha e o cimento asfáltico acontece mediante a absorção de óleos aromáticos do cimento asfáltico à cadeia polimérica da borracha natural ou sintética. Um dos elementos que podem ser empregados na produção do asfalto-borracha é o óleo extensor, produto rico em óleos aromáticos, que tem como função facilitar a incorporação da borracha moída ao cimento asfáltico, proporcionando um ligante asfalto-borracha de melhor qualidade. A adição do óleo extensor pode corrigir a composição química do cimento asfalto-borracha, proporcionando ao ligante uma viscosidade aceitável para uso na pavimentação. (FAXINA, 2002).

O presente trabalho tem como objetivo analisar o efeito da borracha moída de pneu e do resíduo de óleo de xisto sobre algumas propriedades mecânicas em misturas asfálticas densas. Para atingir o objetivo proposto, foi elaborado um estudo que compreende a modificação de um ligante asfáltico de referência (CAP 30/45) com diversos teores de borracha moída de pneu e resíduo de óleo de xisto. Como objetivo específico, tem-se a avaliação das propriedades dessas misturas, por meio de uma investigação laboratorial, através da produção de corpos-de-prova segundo o Método Marshall e de ensaios para a determinação dos valores de Módulo de Resiliência, Resistência à tração por compressão diametral, assim como verificar a resistência dessas misturas à ação da água.

O trabalho está dividido em seis capítulos. O Capítulo 1 relata as considerações iniciais, referentes à importância da pesquisa, assim como os objetivos do trabalho. O Capítulo 2 se destina à apresentação da revisão bibliográfica sobre o tema, abordando as características dos ligantes e das misturas asfálticas, com enfoque no ligante asfalto-borracha, interação asfaltoborracha, e finalmente os aspectos gerais das propriedades mecânicas, que serão avaliadas, das misturas asfálticas. O Capítulo 3 é destinado ao detalhamento do planejamento do experimento, assim como apresentados a descrição dos materiais e os procedimentos de laboratório realizados. No Capítulo 4 são apresentados os resultados obtidos nos ensaios juntamente com as análises realizadas. O Capítulo 5 é reservado para as conclusões. Ao término, é apresentado o capítulo 6, de referências bibliográficas. 


\section{Capítulo 2}

\section{REFERENCIAL TEÓRICO}

Este capítulo destina-se a apresentar informações relevantes ao tema da pesquisa, permitindo a consolidação de uma base teórica que possa auxiliar tanto na análise dos resultados, como nas conclusões finais do presente trabalho. São considerados, dessa forma, assuntos relacionados a ligantes e misturas asfálticas, asfaltos modificados, asfalto borracha e seu uso em pavimentação asfáltica, seguido de algumas propriedades mecânicas dessas misturas com esse ligante, tais como: ensaios de resistência à tração por compressão diametral, módulo de resiliência e dano por umidade induzida.

\subsection{Ligantes Asfálticos}

O asfalto é um dos mais antigos materiais de construção encontrados na natureza, sendo utilizado há mais de 8000 anos. Na antiguidade, ele era muito usado como argamassa nas edificações e blocos de pavimento, calafetagem de navios e em aplicações como impermeabilizantes. No entanto, a primeira utilização do asfalto na pavimentação ocorreu em Lyon, na França, no ano de 1829, com a utilização de um mastique asfáltico para melhorar as condições de rodagem (MANUAL DO ASFALTO, 1989).

Os asfaltos são materiais aglutinantes de cor escura, constituídos por misturas complexas de hidrocarbonetos não voláteis de elevada massa molecular. Podem ser encontrados em jazidas naturais, na forma de bolsões de asfaltos, originados da evaporação natural das frações mais leves (mais voláteis) de jazidas de petróleo localizadas na superfície terrestre, como lagos de asfaltos. Os asfaltos também podem ser obtidos por destilação do petróleo em unidades industriais, refinarias, e são chamados de cimentos as asfálticos de petróleo (CAP). Em pavimentação, os asfaltos podem ser denominados ligantes asfálticos, cimentos asfálticos ou materiais asfálticos. 
Os cimentos asfálticos de petróleo, produtos derivados da destilação do petróleo, são produzidos para apresentarem características próprias para uso direto nas misturas asfálticas. Oferecem propriedades aglutinantes e impermeabilizantes, também apresentam flexibilidade, durabilidade e alta resistência à ação da maioria de produtos inorgânicos.

As propriedades físicas dos ligantes asfálticos são normalmente expressas por meio da penetração, ponto de amolecimento, susceptibilidade térmica, viscosidade e ductilidade. Para Fox et al. (2006) uma das principais propriedades físicas dos materiais asfálticos é a viscosidade, devido ao fato dessa propriedade estar relacionada diretamente à capacidade de bombeamento, facilidade de mistura e aplicação destes materiais. A viscosidade é uma medida de consistência, definida como a resistência que um determinado material oferece ao escoamento, quando submetido a tensões de cisalhamento.

O ligante asfáltico também apresenta como característica fundamental a suscetibilidade térmica, sendo a temperatura fator preponderante no seu comportamento, alterando seus estado físico e consistência. $\mathrm{O}$ tempo de aplicação de carga também pode modificar o comportamento da mistura, pois um ligante submetido a um mesmo nível de carregamento, porém com diferentes tempos de aplicação apresentará comportamentos distintos. Portanto, nos ensaios para a caracterização dos ligantes asfálticos, devem-se levar em consideração os valores especificados de temperatura, tempo e magnitude de aplicação de carregamentos.

O asfalto pode ser considerado como um material visco-elástico apresentando, assim, comportamento elástico, viscoso e visco-elástico, dependendo da temperatura e do tempo de aplicação da carga. Para temperaturas baixas e tempos curtos de carregamento, o comportamento é essencialmente elástico, enquanto que para temperaturas altas e tempos longos de aplicação de carga, o comportamento torna-se viscoso (TAIRA, 2001).

Quando utilizados em serviços de pavimentação, os ligantes asfálticos devem tornar-se suficientemente líquidos para facilitar a mistura com os agregados e posterior lançamento na pista. Após o lançamento e compactação da pista, devem ficar suficientemente sólidos de modo que as camadas asfálticas do pavimento resistam às ações das cargas do tráfego, mesmo quando submetidas a altas temperaturas, sem sofrer deformações permanentes, e quando expostos a baixas temperaturas devem apresentar flexibilidade suficiente para impedir o aparecimento de trincas na camada asfáltica do pavimento. 
Ao serem utilizados em misturas asfálticas a quente o ligante asfáltico é aquecido e sofre um envelhecimento já na mistura com os agregados pétreos, que também se encontram aquecidos. Em geral, esse envelhecimento tem como efeito o enrijecimento da mistura, que pode ser favorável quanto à distribuição de carga e deformações permanentes, porém pode favorecer o aparecimento de trincas de fadiga e até mesmo, eventualmente, a desintegração da camada asfáltica.

Quanto à sua classificação, até 2005, os asfaltos eram classificados de duas maneiras: pela viscosidade $\left(\mathrm{a} 60^{\circ} \mathrm{C}\right.$ ) resultando em três classes CAP-7, CAP-20 e CAP-40 e/ou pela penetração $\left(25^{\circ} \mathrm{C}\right)$, CAP 30-45, CAP 50-60, CAP 85-100 e CAP 150-200 (ABNT MB-827). Atualmente, através da norma ABNT NBR 6576, os asfaltos são classificados pela penetração como: CAP 30-45, CAP 50-70, CAP 85-100 e CAP 150-200.

O desempenho das rodovias está atrelado ao comportamento do ligante asfáltico, que necessita suportar os carregamentos oriundos do tráfego em diferentes condições climáticas, e transferi-los para as camadas inferiores. Portanto, ele precisa ser flexível em temperaturas baixas para prevenir as trincas térmicas no pavimento, do mesmo modo que suficientemente rígido em temperaturas altas para prevenir as deformações permanentes. No entanto, as misturas asfálticas convencionais, nem sempre, apresentam propriedades adequadas, ou seja, têm um desempenho desejável. Diante deste contexto, umas das tentativas para melhorar as propriedades mecânicas das misturas asfálticas, bem como reduzir o passivo ambiental causado pela crescente deposição inadequada de pneumáticos na natureza, é o estudo que muitos países vêm desenvolvendo para a incorporação de borracha moída de pneu, BMP, em revestimentos asfálticos.

\subsubsection{Constituição química do asfalto}

$\mathrm{O}$ asfalto, sendo uma mistura de grandes cadeias de hidrocarbonetos, possui como principais elementos na sua constituição o Carbono e o Hidrogênio correspondendo a, aproximadamente, 93 a 99\% da sua constituição, dependendo do petróleo do qual é originado. Elementos como: Enxofre, Nitrogênio e Oxigênio, chamados de heteroátomos, depois do carbono e hidrogênio, são os mais presentes no asfalto. O desequilíbrio de cargas (polaridade) 
e a presença de grupos funcionais (funcionalidade) causados pelos heteroátomos têm grande contribuição nas características dos asfaltos (PINHEIRO, 2004).

Segundo Tissot e Weltre (1984) ${ }^{1}$ apud Antunes (2001), a composição dos asfaltos pode ser definida de forma aproximada como:

- Hidrocarbonetos saturados: que é constituído de alcanos (parafínicos) que apresentam cadeias abertas normais e ramificadas, só apresentam simples ligações entre os átomos de carbono. Sua nomenclatura é caracterizada pela terminação ano (metano, etano, propano) e representam a maior parte da constituição do gás natural e do petróleo; e cicloalcanos (naftênicos), que são caracterizados por cadeias cíclicas de ligações simples, são insolúveis em água.

- Hidrocarbonetos aromáticos: são definidos como sendo os hidrocarbonetos que possuem um ou mais anéis benzênicos, ou seja, anéis contendo seis átomos de carbono, incluindo aromáticos puros, moléculas de cicloalcanos aromáticos (naftênico-aromáticos), e benzotiofenos (compostos cíclicos contendo átomos de enxofre). Os aromáticos são considerados os mais tóxicos dos hidrocarbonetos e são bastante solúveis em água, o que representa maior perigo aos organismos vivos.

- Resinas e asfaltenos: são constituídos por frações policíclicas dos constituintes do óleo crú, de alto peso molecular, com átomos de Nitrogênio e Enxofre na sua maioria. Os asfaltenos são insolúveis em alcanos leves (precipitam com n-hexano).

- Hidrocarbonetos insaturados (Alquenos): são caracterizados pela presença de átomos de carbono unidos por ligações covalentes duplas. Alquenos contendo de dois a quatro átomos de carbono são gases à temperatura ambiente, enquanto os que contém mais de cinco átomos são, geralmente, líquidos. Apesar de não existirem no óleo bruto, os alquenos são formados em larga escala quando o óleo é craqueado. São mais tóxicos que os alcanos, porém menos que os aromáticos.

\footnotetext{
${ }^{1}$ TISSOT B.P., WELTRED.H. (1984). Petroleum formation and ooccurence, Springer Verlag, Berlim.
} 
O fracionamento químico separa o CAP em compostos saturados, nafteno-aromáticos, polararomáticos e asfaltenos (insolúveis em n-heptano). Os asfaltenos separam-se primeiro, por precipitação, com a adição de n-heptano. Os outros constituintes, denominados maltenos, solúveis em n-heptano, são separados por cromatografia de adsorção. Os asfaltenos são aglomerados de compostos polares e polarizáveis, formados em conseqüência de associações intermoleculares. São considerados responsáveis pelo comportamento reológico dos CAP e constituídos de hidrocarbonetos naftênicos condensados e de cadeias curtas de saturados. (LEITE e BITTENCOURT, 2004).

\subsection{Asfaltos Modificados}

Para ampliar sua resistência, os ligantes asfálticos de petróleo podem ser modificados através da adição de asfaltos naturais como gilsonita (EUA), asfaltita (Argentina), e asfalto de Trinidad ou ainda por adição de fíleres (cal, cimento, sílica, etc), fibras (fibra de vidro, fibras de celulose e fibras poliméricas) (MAGALHÃES, 2004). A modificação mais empregada atualmente é através do uso de polímeros (SBR, SBS, EVA, etc) e borracha de pneu (LEITE, 1999).

Segundo Taira (2001), um asfalto modificado deve possuir algumas propriedades diferenciadas em relação ao asfalto convencional, tais como:

- aumento da coesão;

- $\quad$ aumento da adesão;

- diminuição da suceptibilidade térmica;

- aumento da resistência ao envelhecimento;

- aumento da elasticidade;

- melhoria das propriedades reológicas.

Um ligante modificado ideal deve apresentar baixa susceptibilidade térmica na faixa de temperaturas a que estará sujeito em serviço. A resistência à deformação permanente (em altas temperaturas), a resistência às trincas térmicas (em baixas temperaturas) e as características de fadiga devem ser altas. Ao mesmo tempo deve, no mínimo, manter as mesmas qualidades de adesão dos ligantes tradicionais (BRÛLÉ, 1996). 
O uso de ligantes asfálticos modificados com borracha na confecção de misturas asfálticas a quente iniciou-se na década de 40. A incorporação da borracha reciclada e granulada aos ligantes asfálticos teve como objetivo melhorar o comportamento mecânico das misturas asfálticas e diminuir o nível de poluição ambiental (MOHAMMAD et al., 2000). Em congruência com esse pensamento está a abordagem de Leite (1999), afirmando que devido à junção de razões econômicas, o alto custo dos polímeros e o problema real de eliminação dos pneus inservíveis, levaram à tentativa de modificar as propriedades do asfalto com borracha moída de pneu.

Leite (1999), em sua tese de doutorado, analisou o preparo e a caracterização de asfaltos modificados por diversos tipos de polímeros, e observou que a borracha de pneus é a matéria prima mais barata, dentre os diversos tipos de polímeros testados.

As misturas asfálticas devem possuir flexibilidade suficiente para suportar as solicitações do tráfego e resistência à tração adequada para evitar rupturas precoces. A vida de fadiga deve ser a maior possível, daí o emprego de asfalto modificado por polímero, que tem a função de aumentar a vida de fadiga da mistura devido à melhora na recuperação elástica imprimida ao ligante pelo polímero (MOURÃO, 2003).

Nos estudos de Amaral (2000) foram avaliadas as vantagens e desvantagens da utilização de asfalto modificado com polímero SBS em misturas densas com seixo rolado como agregado graúdo. Para a avaliação foram realizados ensaios Marshall, de fluência por compressão uniaxial estática a $40^{\circ} \mathrm{C}$, de módulo de resiliência por compressão diametral dinâmica e de resistência à tração por compressão diametral à $25^{\circ} \mathrm{C}$. As misturas com asfalto modificado apresentaram melhor desempenho nos ensaios Marshall e de resistência à tração; da mesma maneira, apresentaram melhores relações entre o módulo de resiliência e a resistência à tração. Porém, os resultados do ensaio de fluência por compressão uniaxial estática nem sempre indicaram as misturas com asfalto modificado como as de melhor comportamento quanto à deformação permanente.

Taira (2001) avaliou o desempenho de misturas asfálticas densas utilizando ligante convencional (CAP 20) e ligante modificado com polímero SBS, por meio de ensaios Marshall, de fluência por compressão uniaxial estática e dinâmica, de resistência à tração por compressão diametral e de módulo de resiliência por compressão diametral dinâmica. O efeito 
da adição de polímeros não foi claramente distinguido na misturas asfálticas quando avaliados os resultados dos ensaios de fluência por compressão uniaxial estática e módulo de resiliência, porém os resultados dos ensaios de fluência dinâmica e estabilidade Marshall identificaram melhor comportamento das misturas com asfaltos modificados.

O estudo realizado por Santos (2005) avaliou o comportamento à fadiga de algumas misturas asfálticas compostas com diferentes asfaltos, um modificado com polímero SBS, um com borracha moída de pneu e um convencional. Os resultados indicaram que, na maioria dos casos, as misturas com CAP 20 + SBS apresentaram melhor desempenho (maior vida de fadiga), seguida da mistura com adição de $20 \%$ de borracha e, por último, a mistura de referência (asfalto convencional).

Apesar de modificar significativamente as propriedades do betume, a utilização de elastômeros vulcanizados, inclusive pó de borracha proveniente de reciclagem de pneumáticos é de difícil dispersão, requerendo altas temperaturas e tempo de digestão. Os resultados que se tem obtido são misturas heterogêneas e a borracha agindo mais como um fíler flexível (GALVÃO, 2001).

\subsection{Asfalto-Borracha}

\subsubsection{Introdução}

Problemas ambientais são preocupações tanto do governo quanto de empresas privadas e, dentre essas preocupações, como uma das principais pode-se destacar o reaproveitamento de produtos descartáveis. Para os pneus inservíveis existem diversas formas de reaproveitamento, uma delas, o emprego na pavimentação asfálticas. No Brasil, pesquisas sobre o emprego de borracha de pneus descartados em pavimentação asfálticas iniciaram-se nos anos 90 (FAXINA, 2002).

Segundo Oda (2000) além da aplicação em pavimentação, os pneus descartados também podem ter outras aplicações em engenharia civil, como em obras de contenções, na construção 
de quebra-mares, na construção de parques infantis, no controle de erosões, na drenagem de gases em aterros sanitários, entre outros.

A borracha de pneu também pode ser empregada, em associação com outros materiais, na produção de tapetes para automóveis e banheiros, pisos antiderrapantes, adesivos, cestos de lixos, etc. Do mesmo modo, os pneus descartados podem ser aproveitados, em conjunto com xisto betuminoso, na produção de óleo e gás, por meio do processo desenvolvido pela Petrobrás de São Mateus do Sul, PR, que também produz o óleo extensor AR-5, resíduo do óleo de xisto, estudado no presente trabalho (FAXINA, 2002).

As misturas compostas com asfalto modificado e borracha granulada reciclada de pneus usados, além de apresentarem excepcionais propriedades físicas, químicas, físico-químicas e reológicas, ainda contribuem para minimizar os problemas referentes ao meio ambiente devido o consumo dos pneus usados, materiais extremamente agressivos ao meio ambiente e com durações de vida expectáveis ordem de mil anos (SOUSA et al, 2000).

Apesar de possuir custos iniciais superiores em relação às misturas convencionais, as misturas com asfalto-borracha podem ter menores espessuras da camada de revestimento, assim como prolongar a vida útil do pavimento (GRECO, 2004).

\subsubsection{Histórico}

Durante muitos anos, engenheiros e químicos trabalharam misturando borracha natural (látex) e borracha sintética (polímeros) em ligantes asfálticos na tentativa de melhorar as suas propriedades elásticas. Mas é só na década de 40 que se iniciou a história da adição de borracha de pneus reciclada em materiais para pavimentação asfáltica com a Companhia de Reciclagem de Borracha, U.S. Rubber Reclaiming Company, que introduziu no mercado um produto composto de material asfáltico e borracha desvulcanizada reciclada, denominado Ramflex (ODA, 2000).

A fabricação de asfalto modificado com a incorporação de borracha granulada reciclada de pneu teve origem em 1960 no Estado do Arizona/EUA com estudos e experiências realizadas 
pelo Eng ${ }^{\mathrm{o}}$ Charles H. McDonald. Dentre suas principais aplicações podem ser citadas a conservação corretiva periódica mas selagem de fissuras e juntas, os tratamentos superficiais e os concretos asfálticos usinados a quente (CAMPO et al., 2000). Em 1963, este procedimento foi oficialmente reconhecido como "Técnica de Reparação de Remendos" pelo Departamento de Transportes do Arizona, ADOT - Arizona Departament of Transportation, que foi incorporado às especificações de serviço.

O ligante asfalto-borracha utilizado para aplicação na selagem de trincas era inicialmente aplicado manualmente. Somente a partir de 1970 é que se obteve sucesso com a distribuição do ligante modificado com borracha de forma mecânica. A partir daí, deu-se início então à execução de alguns tipos de tratamento superficiais simples e duplos utilizando como ligante o asfalto-borracha. Em 1975, pela primeira vez, foram empregados os ligantes asfálticos modificados com borracha na fabricação de misturas asfálticas usinadas a quente, tendo-se executado misturas de graduação densa, de graduação descontínua e de graduação aberta.

Atualmente, devido ao pleno conhecimento e domínio total das técnicas de formulação, usinagem e execução, a preferência nos EUA para constituição das camadas de desgaste tem recaído nas misturas de graduação aberta; já o Departamento de Transportes da Califórnia tem aplicado tanto misturas de graduação densa como também descontínua e abertas (Campos et al., 2000).

Em 1991, a Lei sobre a Eficiência do Transporte Intermodal de Superfície nos EUA estabeleceu quantidades mínimas para utilização de asfalto modificado com borracha de pneu. A exigência de utilização mínima de pavimento asfáltico contendo borracha reciclada como uma porcentagem do material asfáltico tinha como finalidade tentar diminuir o problema ambiental provocado pelos pneus descartados (HANSON et al, 1994).

Na Europa, as pesquisas referentes à incorporação de borracha ao cimento asfáltico também começaram na década de 1960. Na França, a incorporação de borracha ao cimento asfáltico iniciou-se em 1981, pela empresa Beugnet. No processo desenvolvido por esta empresa, a borracha moída de pneu era adicionada ao cimento asfáltico à temperatura de $200^{\circ} \mathrm{C}$, empregando óleo extensor. A proporção de borracha utilizada variava de 10 a 30\% e a de óleo entre 3 a 15\% em relação ao peso do cimento asfáltico (FAXINA, 2002). 
Uma das principais utilizações do asfalto-borracha consiste na recuperação de revestimentos degradados com aplicação de misturas densas ou de graduações descontínuas em trechos entregues às concessionárias privadas nos estados de São Paulo, Rio Grande do Sul e Paraná. (Severo et al., 2003).

O CONAMA (Conselho Nacional do Meio Ambiente), segundo a resolução de $n^{\circ} 258 / 99$, de 26 de agosto de 1999, determina os prazos para que as indústrias de pneumáticos e importadores façam a coleta e dêm destino final dos pneus descartados de forma ambientalmente adequada. Dessa forma, essa regulamentação proporcionou incentivos para o desenvolvimento de pesquisas relacionadas a novos estudos da reciclagem de pneus tanto para pavimentação quanto para outros fins.

Outra iniciativa do Poder Legislativo que cabe ressaltar é o projeto de lei $n^{\circ} 133 / 2004$, da Deputada Estadual do estado do Paraná Cida Borghetti, referente à destinação de pneumáticos inservíveis para a produção de misturas asfálticas, prevendo em seu artigo segundo...

“Art. $2^{\circ}$ Os pneumáticos recolhidos deverão ser destinados à
pavimentação asfáltica, em processo úmido ou em processo seco, na
proporção mínima de $80 \%$ (oitenta por cento) do total de pneumáticos
recolhidos, observadas as quantidades e os prazos fixados pela
Resolução do CONAMA $n^{\circ}$ 258/1999.”

Cimino (2004) analisou, em seu estudo, os procedimentos e as tecnologias que vêm sendo adotadas para gerenciar os pneumáticos inservíveis no território nacional, após a instituição da Resolução CONAMA n $n^{0}$ 258/99. Os dados e as informações coletadas mostraram que as metas vêm sendo atingidas tanto no setor produtivo quanto pelo setor de importação de pneumáticos. Para o tratamento e a disposição final desses resíduos, foram identificadas soluções que visam à geração de energia por meio de co-processamento e pirólise de pneus inservíveis triturados.

No Brasil, o estudo sobre o asfalto-borracha foi iniciada nas pesquisas de LEITE (1999) e ODA (2000). Além das pesquisas realizadas no CENPES/Petrobrás, pode-se citar trabalhos considerados importantes para o desenvolvimento da tecnologia que vem sendo empregada na modificação dos ligantes asfálticos convencionais com borracha moída de pneu, como, por 
exemplo, Momm \& Salini (2000), Severo et al. (2003), Leite et al. (2003), Specht \& Ceratti (2003), Barros \& Vasconcelos (2003), Pinheiro \& Soares (2003), Dantas Neto (2004), etc. O quadro 01 apresenta uma relação de alguns trechos executados com ligantes asfálticos modificados com borracha no Brasil.

Quadro 01: Relação de alguns serviços executados com asfalto borracha no Brasil

\begin{tabular}{|c|c|c|c|}
\hline $\begin{array}{c}\text { Ano da } \\
\text { realização } \\
\text { da obra }\end{array}$ & $\begin{array}{c}\text { Extensão } \\
\text { (m) }\end{array}$ & Concessionárias & Localização \\
\hline 2001 & 725 & Univias/RS & BR/116-RS, entre Guaíba e Camaquã \\
\hline 2001 & 7.321 & Rodonorte/PR & PR/090, entre Piraí do Sul e Ventania \\
\hline 2002 & 5.405 & Rodonorte/PR & BR/376-PR, entre Califórnia e Apucarana \\
\hline 2002 & 1.200 & Intervias/SP & SP/330, Via Anhanguera em Araras \\
\hline 2002 & 1.180 & Rodonorte/PR & BR/277-PR, travessia de Campo Largo \\
\hline 2002 & 700 & Ecovias/SP & SP/150, Via Anchieta \\
\hline 2002 & 970 & Viapar/PR & BR/376-PR, entre Maringá e Paranavaí \\
\hline 2002 & 1.500 & Rod. das Cataratas/PR & BR/277-PR, trevo em Capitão L. Marques \\
\hline 2002 & 500 & Pref. de Curitiba/PR & Rua David Tows - Xaxim \\
\hline 2002 & 650 & Viapar/PR & BR/376-PR, entre Mandaguari e Marialva \\
\hline 2002 & 5.000 & Ecovia/PR & BR/277-PR, entre Curitiba e Paranaguá \\
\hline 2003 & 5.000 & Univias/RS & BR/386-RS, entre Pouso Novo e Soledade \\
\hline 2003 & 9.000 & $\mathrm{SP} / \mathrm{Vias} / \mathrm{SP}$ & SP/255, entre Avaré e Taquarituba \\
\hline 2003 & 2.457 & Coviplan /RS & BR/386-RS, entre Soledade e Jarazinho \\
\hline 2003 & 6.000 & Univias/RS & BR/386-RS, entre Pouso Novo e Soledade \\
\hline 2003 & 1.000 & Vioeste/SP & SP/280 Pista Leste (Km 69/70) \\
\hline 2003 & 2.800 & Caminhos do Paraná/PR & $\mathrm{BR} / 373$ e $\mathrm{BR} / 277$ \\
\hline 2003 & 26.000 & SP/Vias SP & SP 280 Castelo Branco \\
\hline 2003 & 186.000 & Rodonorte/PR & Vários \\
\hline 2003 & 11.800 & Econorte/PR & PR/323 entre Sertaneja e Divisa de SP/PR \\
\hline 2005 & 28.000 & $\mathrm{DER} / \mathrm{PR}$ & PR 092 - entre Wenceslau Braz e Quatiguá \\
\hline 2005 & 32.000 & $\mathrm{DER} / \mathrm{PR}$ & PR 092 Quatiguá a BR 153 Sto A.da Platina \\
\hline 2005 & 16.000 & DEINFRA/SC & BR 470 - entre Campos Novos e Celso Ramos \\
\hline 2006 & 11.500 & $\mathrm{DER} / \mathrm{PR}$ & PR 170 - entre Porecatu e Porto Capem \\
\hline Total & 362.708 & & \\
\hline
\end{tabular}

Quadro adaptado de CORDEIRO (2006). As demais informações são oriundas de sites da internet e informações obtidas por telefone com empresas e órgãos responsáveis pelas rodovias. 
Os primeiros trechos experimentais foram construídos em rodovias concessionadas como a BR-116 no Rio Grande do Sul. Atualmente, acredita-se que o Brasil possui mais de $1000 \mathrm{~km}$ de rodovias, entre federais e estaduais, ruas e avenidas municipais pavimentadas com a utilização de borracha reciclada de pneus (CORDEIRO, 2006). No Estado de São Paulo, acompanhadas pelas áreas técnicas da ARTESP, foram iniciados os serviços com asfalto borracha em abril de 2002, aplicado inicialmente na SP-330 Via Anhangüera, trecho concedido à Intervias. (SILVA JR, 2005).

\subsubsection{Método de Obtenção do Asfalto-Borracha}

Borrachas são polímeros termorrígidos. A borracha natural, no seu estado primário, consiste de cadeias de poliisopreno, com alto peso molecular. As borrachas ou elastômeros são classificados em duas grandes famílias: borracha natural, de nome químico poliisopreno, obtida a partir da coagulação do látex da árvore Hévea Brasiliensis e as borrachas sintéticas, que são obtidas a partir do petróleo ou hulha (CORDEIRO, 2006).

A composição da borracha utilizada em pneu varia bastante, mas consiste essencialmente de borracha natural, borracha estireno-butadieno e negro de fumo. Para o reaproveitamento da borracha de pneu há antes do processo de moagem a necessidade de se retirar o aço e as fibras. A moagem pode ser mecânica, à temperatura ambiente, ou criogênica, à temperatura abaixo da temperatura de transição vítrea dos elastômeros presentes nos pneus (LEITE, 1999).

Existem quatro métodos para trituração da borracha de pneu descartado. O processo “crackermill" realizado em temperatura ambiente, gera partículas irregulares com grande área superficial, com tamanho variando de 4,8 a $0,42 \mathrm{~mm}$. O processo "granulator" executado a temperatura ambiente, fornece partículas de forma cúbica e uniforme com pequena área superficial, com tamanhos variando de 9,5 a 2,0mm. O processo "micromill" também realizado em temperatura ambiente, gera partículas finas, com tamanho variando de 0,42 a 0,075mm. O processo “cryogenic" baseia-se na imersão da borracha em nitrogênio líquido (90 a $-200^{\circ} \mathrm{C}$ ), sendo que abaixo de temperaturas de $-60^{\circ} \mathrm{C}$ a borracha se torna um material frágil de fácil trituração (FAXINA, 2002). 
O componente negro de fumo atua melhorando as propriedades mecânicas da borracha empregada na fabricação dos pneus, além de ser uma espécie de agente antioxidante na presença da irradiação ultravioleta. (DANTAS NETO, 2004). A proporção entre os diferentes componentes no pneu pode variar de um fabricante para o outro em função das características do pneu e/ou das exigências do mercado automotivo.

Segundo Bertollo (2002) os negros-de-fumo (responsáveis pela cor dos pneus) ocupam um lugar preponderante na fabricação dos pneus, pois conferem às misturas de borracha propriedades mecânicas que permitem tornar 10 vezes maior sua resistência mecânica ao desgaste.

São dois os elementos básicos para produção do ligante asfalto-borracha, a saber: o cimento asfáltico e a borracha moída do pneu, podendo-se utilizar um óleo extensor com o objetivo de melhorar a compatibilidade entre esses dois componentes. A qualidade do ligante asfaltoborracha está atrelada principalmente ao tipo, tamanho e teor das partículas de borracha.

O bom desempenho da borracha como melhorador das propriedades do CAP depende da compatibilidade entre eles. $\mathrm{O}$ tipo e a quantidade de óleos aromáticos presentes no ligante desempenha um papel significativo na determinação desta compatibilidade. Para melhorar a compatibilidade entre o ligante e a borracha pode ser utilizado um óleo extensor de borracha, que ainda serve para diminuir a viscosidade do ligante asfalto-borracha. No entanto, deve-se ter um cuidado especial com a temperatura de reação, pois temperaturas elevadas podem provocar o envelhecimento precoce do CAP, mudando suas características (PINHEIRO et al. , 2003).

A borracha de pneu moída pode ser utilizada tanto como modificador do asfalto, quanto como agregado em misturas asfálticas. A incorporação da borracha de pneu moída às misturas asfálticas pode ser realizada de três formas: mediante processo úmido, processo seco e uma variação do processo úmido denominada de "Terminal Blend" (TAKALLOU \& TAKALLOU, 2003). No "processo seco" as partículas de borracha são primeiramente adicionadas ao agregado mineral antes da adição do ligante betuminoso. No "processo úmido" as partículas de borracha moídas são misturadas ou incorporadas ao ligante asfáltico antes da adição do agregado mineral. 
O asfalto-borracha produzido pela via úmida é resultado da combinação de um cimento asfáltico convencional, borracha granulada reciclada e outros aditivos, caso seja necessário. A borracha granulada de pneus deve ser misturada ao cimento asfáltico convencional suficientemente aquecido de forma a haver o amolecimento das partículas de borracha antes do uso. Os aditivos são normalmente óleos extensores, que visam melhorar a trabalhabilidade dos asfaltos-borracha ou melhorar a compatibilidade entre o ligante convencional e a borracha granulada.

Cabe ressaltar, que o processo de misturação do asfalto-borracha com os agregados minerais e a aplicação do concreto asfáltico são similares aos procedimentos adotados em misturas com ligantes convencionais, salvo em relação às temperaturas. Nos concretos asfálticos preparados com asfalto-borracha temperaturas de mistura e de compactação normalmente são mais elevadas em virtude da maior viscosidade do asfalto-borracha (ROSENO, 2005).

No processo úmido, o ligante asfáltico é aquecido a temperaturas ordem de $190^{\circ} \mathrm{C}$, em um tanque de superaquecimento em condições herméticas, sendo em seguida, levado para um tanque de mistura apropriado. Nesse tanque ocorre adição da borracha moída ao ligante convencional, com período de misturação de 1 a 4 horas a uma determinada temperatura (VISSER \& VERHAEGHE, 2000). O equipamento misturador deve possuir um sistema para controlar a temperatura e o tempo de reação de maneira constante e mais uniforme possível, além de um sistema de agitação que evite a segregação das partículas de borracha. A quantidade de borracha incorporada ao cimento asfáltico pelo processo úmido varia de $5 \mathrm{a}$ $25 \%$ em peso em relação ao cimento asfáltico, geralmente com partículas inferiores a $2 \mathrm{~mm}$ (FAXINA, 2002).

Normalmente, a preparação do ligante modificado com borracha é just in time preparada no canteiro de obras e utilizada imediatamente. No Brasil está sendo utilizado o processo úmido através da tecnologia terminal blending, onde a mistura é efetuada em uma unidade central e transportada até o local de aplicação (SPETCH, 2004).

A interação entre o ligante asfáltico e a borracha moída, no processo úmido, é classificada como uma reação. O grau de modificação do ligante depende de vários fatores, incluindo a granulometria, textura da borracha, proporção de ligante asfáltico e borracha, tempo e 
temperatura de reação, compatibilidade com a borracha, a energia mecânica durante a mistura e reação, e o uso de aditivos (ODA, 2000).

Para Monm e Salini (2000), a borracha não é inerte e passa por mudanças durante o tempo em que permanece em contato com o cimento asfáltico. Este processo de modificação ocorre naturalmente durante o tempo em que a mistura é transportada (no caminhão) para o local da obra e até que a temperatura seja reduzida à temperatura ambiente. No laboratório é possível simular o feito do tempo pela colocação da mistura em uma estufa com $10^{\circ} \mathrm{C}$ abaixo da temperatura de mistura.

No processo seco, o agregado é aquecido a temperaturas de aproximadamente $200^{\circ} \mathrm{C}$, quando então, a borracha é adicionada e processa-se a mistura por um tempo próximo de 15 segundos, ou até a formação de uma mistura homogênea agregado-borracha. Posteriormente é adicionado o ligante betuminoso a esta composição final por meio de processos convencionais de usinagem (VISSER \& VERHAEGHE, 2000). Nesse processo se adiciona de 3 a 5\% de borracha em relação à massa total de agregados minerais, com partículas de 1,6 a 6,4mm. A quantidade de borracha consumida nesse processo chega a ser 2 a 4 vezes maior que pelo processo úmido (FAXINA, 2002).

Segundo Mohammad et al. (2000), no processo seco as dimensões das partículas de borracha são superiores aquelas utilizadas no processo úmido. Do mesmo modo, a borracha granulada substitui uma parcela da mistura dos agregados minerais, funcionando como um material inerte. Segundo Faxina (2002), o processo seco é limitado à aplicação em revestimento asfáltico, enquanto que o processo úmido pode ser empregado em selagem de trincas, tratamentos superficiais, camadas de ligação e concreto asfáltico. Os produtos finais obtidos pelos dois processos são denominados de agregado-borracha quando obtido pelo processo seco e asfalto-borracha pelo processo úmido.

\subsubsection{Interação Asfalto-Borracha}

Ao se incorporar borracha moída ao ligante asfáltico de base, é produzido um ligante asfáltico modificado que apresenta propriedades diferentes daquelas do ligante asfáltico inicial. Durante o processamento do asfalto-borracha ocorrem alterações das propriedades do ligante 
asfáltico em virtude das mudanças químicas e/ou físicas, em um processo denominado interação asfalto-borracha. $\mathrm{O}$ entendimento do fenômeno de interação entre o asfalto a borracha permite aos produtores do ligante asfalto-borracha ter maior controle sobre a qualidade do produto final (FAXINA, 2006).

Segundo Patriota (2004), os elastômeros ou borrachas são polímeros lineares amorfos que, quando submetidos ao processo de vulcanização, adquirem uma estrutura parcialmente reticulada que lhes confere propriedades elásticas. A vulcanização tem como resultado a transformação de um produto plástico, como é a borracha virgem, em outro elástico, como é a borracha vulcanizada.

O resultado da junção do asfalto e a borracha é um produto com partículas sólidas ou semisólidas dispersas na matriz asfáltica, entretanto, na maioria das vezes, os dois materiais não são quimicamente compatíveis. A borracha, por ser vulcanizada, durante a mistura como asfalto, não se funde, e desta maneira não se incorpora à sua estrutura polimérica. Portanto, não adquire estabilidade semelhante aos outros asfaltos modificados com polímeros virgens, resultando em um produto sujeito à separação (FAXINA, 2006).

Para Abdelrahman \& Carpenter (1999), os dois principais mecanismos de interação que afetam as propriedades do asfalto-borracha durante sua produção são o inchamento das partículas e a degradação, que ocorre na forma de desvulcanização e despolimerização. Esses mecanismos ocorrem quando o asfalto-borracha é submetido a diferentes combinações de temperatura e tempo de interação.

Segundo Faxina (2006), o inchamento é um processo de difusão, e não um processo químico, que resulta do movimento do líquido para dentro da matriz do polímero. O solvente penetra nas partículas de borracha, proporcionando um aumento nas suas dimensões, até que a concentração de solvente seja uniforme e se estabilize. Para Billiter (1997), a desvulcanização é a quebra das ligações cruzadas enxofre-enxofre ou carbono-enxofre, que são formadas durante o processo de vulcanização na produção do pneu e a despolimerização corresponde à quebra das cadeias poliméricas (ligação carbono-carbono).

A despolimerização ocorre devido à completa digestão das partículas menores de borracha, enquanto que a desvulcanização produz o amolecimento das partículas de borracha de 
maiores dimensões imersas no ligante e posterior inchamento. O processo de interação entre as partículas de borracha e o ligante asfáltico acompanha atividades de despolimerização e inchamento das partículas de borracha durante a mistura. Temperaturas elevadas induzem os processos de despolimerização e inchamento das partículas de borracha, enquanto que baixas temperaturas apenas contribuem para o processo de inchamento (LEITE et al, 2000).

Holleran \& Reed (2000) descrevem um possível modelo para explicar o processo de interação entre as partículas de borracha e o ligante convencional. Segundo esses autores, os asfaltenos e as frações leves (óleos maltenos, resinas, etc) dos ligantes asfálticos convencionais interagem com as partículas de borracha formando uma película de gel sobre estas partículas, produzindo um inchamento. Segundo Dantes (2004), a absorção das frações leves do ligante convencional pelas partículas de borracha progride com o tempo sob elevadas temperaturas, causando um aumento da viscosidade do asfalto-borracha.

Segundo Leite (1999), na interação asfalto-borracha, a borracha incha devido à absorção de óleo formando um gel viscoso que resulta da redução da distância entre as partículas da borracha, aumentando a viscosidade. Para Stroup-Gardiner et al. (1993), a alteração do tamanho das partículas, reduzindo a distância entre elas, e o espessamento da fase líquida proporcionam o aumento da viscosidade do asfalto-borracha. Um ligante modificado com $15 \%$ de borracha pode ter sua viscosidade original, a altas temperaturas, aumentada em 10 vezes ou mais.

Para temperatura bastante elevada, tempo de processamento muito longo e nível de cisalhamento muito alto, o inchamento continuará até o ponto de degradação da borracha, que ficará dispersa no ligante asfáltico, podendo dessa maneira ocorrer uma redução da viscosidade. (ABDELRAHMAN \& CARPENTER, 1999).

Para os mesmos autores, a despolimerização e a desvulcanização reduzem as moléculas do ligante asfáltico a moléculas de menor peso molecular e esse processo ocorre no início da interação, para temperaturas altas de processamento, e continuam se desenvolvendo até a destruição total das moléculas poliméricas, caso o ligante seja exposto a temperaturas altas por um tempo longo. Para Billiter et al (1997), a despolimerização e a desvulcanização provocam uma redução parcial da elasticidade da borracha, permitindo a digestão do polímero 
pelo ligante asfáltico, produzindo um produto mais homogêneo e que apresenta melhores propriedades de compactação e menor tendência de separação.

O tipo de borracha utilizada (sintética ou natural) afeta as propriedades do asfalto-borracha. Em relação à recuperação elástica do asfalto-borracha, a borracha natural é melhor que a borracha sintética, porém a borracha sintética se mostra menos sensível em relação aos efeitos de tempo e temperatura de processamento.

É desejável que o ligante asfáltico empregado no processo úmido contenha uma concentração relativamente alta de frações leves, que pode ser obtida pela adição de óleos extensores ou pela seleção de ligantes menos consistentes (FAXINA, 2006). A utilização de óleos extensores para compensar o aumento da viscosidade que é provocada pelas altas concentrações de borracha é bem sucedida. Os óleos extensores têm por finalidade compensar o acréscimo de viscosidade e fornecer componentes aromáticos em quantidade suficiente para a incorporação efetiva da borracha ao ligante asfáltico (STROUP-DARDINER et al., 1993).

Atualmente ainda não existe no Brasil uma especificação técnica na área federal para produção e emprego do asfalto borracha. Algumas empresas brasileiras possuem normas próprias ou seguem normas internacionais. O Departamento de Estradas de Rodagem do Estado do Paraná (DER/PR), em 09 de maio de 2005, publicou a primeira especificação de serviço de pavimentação com asfalto-borracha no Brasil (ES-P 28/05). No mesmo ano, o Departamento Estadual de Infra-Estrutura do Estado de Santa Catarina (DEINFRA-SC) publicou sua especificação (ES-P 05B/05); do mesmo modo, em fevereiro de 2007 foi divulgada a especificação técnica (ET-DE-P00/030) do Departamento de Estradas de Rodagem do Estado de São Paulo (DER/SP).

As especificações prescrevem as exigências que o asfalto borracha deverá apresentar para ser empregado na pavimentação. A Tabela 01 mostra as características a serem obedecidas e os limites exigidos para os cimentos asfálticos e as misturas asfálticas modificas com asfaltoborracha em camadas de rolamento segundo a especificação do DER/PR. 
Tabela 2.1: Exigências da norma ES-P 28/05 do DER/PR para asfalto-borracha em camadas de rolamento.

\begin{tabular}{|c|c|c|c|}
\hline \multicolumn{4}{|c|}{ Cimento Asfáltico e misturas asfálticas modificados com adição de borracha de pneumáticos } \\
\hline \multirow[b]{2}{*}{ Ensaio } & \multirow[b]{2}{*}{ Característica } & \multicolumn{2}{|c|}{ Exigência } \\
\hline & & Mínima & Máxima \\
\hline DNER-ME 003/94 & Penetração, $100 \mathrm{~g}, 5 \mathrm{~s}, 25^{\circ} \mathrm{C}, 0,1 \mathrm{~mm}$ & 25 & 75 \\
\hline DNER-ME 148/94 & Ponto de Fulgor, ${ }^{\circ} \mathrm{C}$ & 235 & - \\
\hline DNER-ME 193/96 & Densidade Relativa, $25^{\circ} \mathrm{C}$ & 1,00 & 1,05 \\
\hline ABNT-NBR 6560/00 & Ponto de amolecimento, ${ }^{\circ} \mathrm{C}$ & 55 & - \\
\hline NLT 329/91 & Recuperação elástica por torção, \% & 50 & - \\
\hline \multirow[t]{3}{*}{ ABNT-NBR 14736/01 } & Efeito do calor do ar: & & \\
\hline & variação de massa, \% & - & 1 \\
\hline & percentagem de penetração original & 50 & - \\
\hline ASTM- 2196/99 & Viscosidade Brookfield à $175^{\circ} \mathrm{C}, \mathrm{cP}$ & 800 & 2500 \\
\hline DNER-ME 043/95 & Percentagens de vazios, $\%$ & 3 & 5 \\
\hline DNER-ME 043/96 & Relação betume/vazios, \% & 70 & 82 \\
\hline DNER-ME 043/97 & Estabilidade, mínima & $850 \mathrm{kgf}$ & - \\
\hline DNER-ME 043/98 & Fluência, mm & 2,0 & 4,1 \\
\hline DNER-ME 138/94 & $\begin{array}{l}\text { Resitência à tração por compressão diamentral } \\
\text { estática a } 25^{\circ} \mathrm{C}, \mathrm{MPa}\end{array}$ & 0,65 & in) \\
\hline
\end{tabular}

As três especificações citadas anteriormente, no que se refere às características do ligante asfáltico, exibem valores próximos, exceto, no que diz respeito às normas para realização dos ensaios, pois o DER/SP indica a utilização de normas da Associação Brasileira de Normas Técnicas (ABNT), enquanto as outras duas referenciam as normas do DNER. Como exemplo pode-se citar as normas utilizadas pelo DER/SP:

- Penetração (NBR 6576);

- Ponto de fulgor (NBR 11341);

- Densidade relativa (NBR 6296);

- Viscosidade Brookfield (NBR 15235);

- Estabilidade (NBR 12891); e

- Fluência (NBR 12892).

Dentro desse mesmo contexto, pode-se citar uma variação entre as exigências indicadas pelas especificações quando se referem às características dos ligantes asfálticos, a viscosidade Brookfield, que apresenta uma pequena variação na especificação do DER/SP, que apresenta 
valores entre 800 - 2000. Quanto às misturas asfálticas, os valores distintos de cada especificação estão apresentados na Tabela 02.

Tabela 2.2: Diferenças apresentadas pelas especificações de asfalto-borracha.

\begin{tabular}{l|ccc} 
& DER/PR & DEINFRA/SC & DER/SP \\
\hline \multicolumn{1}{c|}{ Características } & $\begin{array}{c}\text { Camada de } \\
\text { rolamento }\end{array}$ & $\begin{array}{c}\text { Camada de } \\
\text { rolamento }\end{array}$ & $\begin{array}{c}\text { Camada de } \\
\text { rolamento }\end{array}$ \\
\hline Percentagem de vazios (\%) & $3-5$ & $3-5$ & 4 \\
\hline Relação betume/vazios (\%) & $70-82$ & $70-82$ & $65-80$ \\
\hline Estabilidade, mínima (Kgf) & 850 Kgf & 800 Kgf & $800 \mathrm{Kgf}$ \\
\hline $\begin{array}{l}\text { Resistência à tração por compressão diametral } \\
\text { estática a } 25^{\circ} \mathrm{C}(\mathrm{MPa})\end{array}$ & 0,65 (mín) & 1,10 (máx) & 0,8 (mín) \\
\hline
\end{tabular}

\subsection{5 Óleo extensor de borracha}

O óleo extensor de borracha AR-5 é um produto desenvolvido pela Petrobras S. A., em São Mateus do Sul, PR. Corresponde a uma fração pesada do óleo de xisto, obtida industrialmente através do fracionamento a vácuo do óleo bruto de xisto. É rico em maltenos e com baixo teor de asfaltenos e, devido à ocorrência de até $36 \%$ em peso de óleos aromáticos, presta-se bem, segundo o produtor, como óleo extensor de borracha.

O papel de um óleo extensor é facilitar a incorporação da borracha moída ao cimento asfáltico, resultando um ligante asfalto-borracha de melhor qualidade. A reação entre a borracha e o cimento asfáltico acontece mediante a absorção de óleos aromáticos do cimento asfáltico à cadeia polimérica da borracha natural ou sintética. O óleo extensor, produto rico em óleos aromáticos, tem como função facilitar a incorporação da borracha moída ao cimento asfáltico, propiciando um ligante asfalto-borracha de melhor qualidade. A adição do óleo extensor pode recompor a composição química do cimento asfáltico, proporcionando ao ligante asfáltico uma viscosidade aceitável para uso na pavimentação. (FAXINA, 2002).

A utilização de óleos extensores para compensar o aumento da viscosidade que é provocada pelas altas concentrações de borracha é bem sucedida. Os óleos extensores têm por finalidade compensar o acréscimo de viscosidade e fornecer componentes aromáticos em quantidade 
suficiente para a incorporação efetiva da borracha ao ligante asfáltico (STROUP-DARDINER et al., 1993).

A adição do resíduo de óleo de xisto no ligante asfalto-borracha proporciona, nas temperaturas de usinagem e compactação, uma redução da viscosidade do ligante, refletindo numa melhor trabalhabilidade das misturas asfálticas. Esse mesmo modificador apresenta efeito positivo sobre algumas propriedades e parâmetros relacionados com a resistência à formação de trincas por fadiga devido ao tráfego, e também nas que indicam resistência à formação de trincas térmicas; entretanto, o resíduo de óleo de xisto apresenta efeito negativo sobre todas as propriedades e parâmetros que indicam resistência à deformação permanente da misturas asfálticas (FAXINA, 2006).

O mesmo autor destaca que embora algumas propriedades sejam melhoradas com a adição do resíduo do óleo de xisto, e outras não, o ganho na trabalhabilidade da mistura asfáltica contribui para a indicação do resíduo do óleo de xisto como óleo extensor, em comparação com a possível perda de desempenho nas misturas asfálticas, sinalizada por algumas propriedades e parâmetros avaliados dos ligantes asfálticos.

Os efeitos da borracha e do óleo, em alguns casos, são opostos, o que sugere que combinações adequadas dos dois modificadores podem ser produzidas, com a finalidade de alcançar os níveis desejados para as propriedades do ligante asfalto-borracha, pois, nas situações em que o efeito do óleo extensor é negativo, a borracha pode atuar no sentido de contrabalançar esse efeito, como por exemplo, nas propriedades e parâmetros relacionados com a deformação permanente.

\subsection{Misturas Asfálticas}

As misturas asfálticas têm como principal exigência atender características como: estabilidade, flexibilidade, durabilidade e resistência à derrapagem. A estabilidade é a característica na qual a mistura resiste à formação de deformações permanentes quando submetida à ação de cargas e pode ser influenciada por fatores como o teor e tipo de cimento asfáltico, forma e textura dos agregados, entre outros. A propriedade de flexibilidade 
proporciona à mistura resistência à fadiga, sendo influenciada pela quantidade e tipo do ligante asfáltico e temperatura. Já a durabilidade permite que a mistura resista à desintegração provocada pela ação do tráfego e das intempéries, podendo ser afetada pela qualidade dos agregados minerais, volume de vazios da mistura, afinidade asfalto / agregado, etc. E por fim, a resistência à derrapagem confere resistência ao deslizamento dos pneus dos veículos, sendo que, para se ter um bom atrito superficial é importante o cuidado com a distribuição granulométrica do agregado e teor de ligante.

Uma mistura asfáltica pode ser definida como uma mistura de materiais granulares, material de enchimento e ligante asfáltico em proporções pré-estabelecidas. Segundo Patriota (2004), na mistura asfáltica o ligante atua como agente aglutinante, desenvolvendo uma ligação entre os agregados, permitindo que o pavimento resista à ação mecânica de desagregação ocasionada pelas cargas geradas pelo tráfego e, como impermeabilizante, garantindo resistência à ação da água.

A mistura asfáltica é um sistema formado por três fases: agregado, asfalto e ar. As propriedades apresentadas pelas misturas asfálticas dependem de sua consideração como um todo, porém sofrem a influência direta das propriedades individuais dos materiais. Os cimentos asfálticos de petróleo (CAP) são adesivos termoplásticos, que podem ser manuseados a quente para aplicação em pavimentos e que assumem um comportamento visco-elástico a temperaturas próximas às de serviço (FURLAN, 2006).

De acordo com Lima (2003), a durabilidade de uma mistura asfáltica pode ser definida como a sua habilidade em manter as propriedades reológicas, coesão e adesão, ao longo do tempo de serviço. Entre os principais fatores que afetam a durabilidade de um revestimento asfáltico, encontram-se os endurecimentos oxidativo, evaporativo e exsudativo.

A qualidade das misturas asfálticas pode ser melhorada com a adição de modificadores de ligante, visto que, o comportamento visco-elástico do ligante é, em grande parte, o controlador do desempenho de uma via, influenciando diretamente no surgimento de trincas por fadiga e deformação permanente, que são os principais defeitos dos pavimentos brasileiros (PINHEIRO, 2004). 


\subsubsection{Misturas asfálticas com asfalto-borracha}

Segundo a especificação do DER/PR (2005), o concreto asfáltico usinado a quente com asfalto borracha é a mistura executada a quente em usina apropriada, com características específicas, composta de agregado mineral graduado, material de enchimento (filer) e ligante asfáltico modificado com adição de pó de borracha de pneumático, usinada, espalhada e compactada a quente, sobre superfície previamente preparada.

Para Salini (1998), o reaproveitamento da borracha de pneus, com o objetivo de incorporá-la ao pavimento asfáltico possui, na Infra-Estrutura Viária, uma posição de destaque. Dentre as vantagens da reciclagem da borracha de pneus destacam-se:

- A solução do problema ambiental dos pneus descartados (poluição);

- A facilidade de transporte do resíduo (carcaça);

- A ausência de risco de manuseio para aos operadores;

- O custo resume-se ao transporte dos locais onde foram gerados ao ponto de utilização;

- As dimensões geométricas padronizadas, o que facilita o desenvolvimento equipamentos de desmonte e trituração, entre outros.

No entanto, para Oda (2000), os objetivos da adição da borracha de pneu usando ligantes asfálticos e misturas asfálticas então relacionados com a minimização do problema de disposição de pneus usados, pois em aterros sanitários ocupam muito espaço e também podem causar problemas ambientar e de saúde publica. Outro fator é a melhora no desempenho dos pavimentos mediante aumento de rigidez a elevadas temperaturas (reduzindo a deformação permanente nas trilhas de rodas); aumento na flexibilidade (retardando o aparecimento de trincas) e aumento da impermeabilidade proporcionada pelos revestimentos asfálticos.

Campos et al. (2000) citam o fato de as misturas asfálticas confeccionadas com asfaltoborracha apresentarem uma maior resistência à derrapagem do que as misturas com ligantes convencionais. De acordo com esses autores isso ocorre porque a borracha reciclada de pneus tem cerca de $35 \%$ de "negro de fumo", que é responsável por proporcionar uma microtextura mais áspera. 
Para Galvão (2001), nos últimos anos, excelentes resultados têm sido obtidos na aplicação, em larga escala, de sistemas poliméricos que apresentam elevadas recuperação elástica e resistência mecânica à tração. Isto não é de surpreender, visto que estas propriedades são essenciais para determinados materiais, como os pneus dos veículos que permanecem resistentes e flexíveis em toda a gama de tensões e temperaturas a que o pavimento é submetido.

\subsubsection{Propriedades das misturas com asfalto-borracha}

Em relação à estabilidade e fluência, estudos mostram que misturas com asfalto-borracha apresentam diminuição da estabilidade em relação às misturas de referência, sendo que a redução pode chegar a $60 \%$ dos valores obtidos nas misturas convencionais. Nota-se que o valor da fluência aumenta, assim como ocorre o aumento do volume de vazios, vazios do agregado mineral, entretanto, não encontra-se variação nos valores da densidade máxima da mistura (HANSON et al., 2004). Esses autores também afirmam que a distribuição granulométrica da borracha influencia os valores de estabilidade e fluência das misturas, sendo que, misturas com partículas grossas de borracha apresentam valores de estabilidade Marshall 49\% menores e valores de fluência Marshall 50\% maiores que os obtidos para uma mistura com a adição de partículas finas de borracha.

Quanto ao módulo de resiliência, estudos realizados por Leite et al. (2000) mostraram uma redução de aproximadamente 50\% nos valores dos módulos de misturas empregando asfaltoborracha, em relação a misturas convencionais (com CAP 20).

Faxina (2002), mediante estudos com a utilização de asfalto convencional e combinação de asfalto modificado (asfalto + borracha + óleo extensor), mostra que a resistência à tração na temperatura de $25^{\circ} \mathrm{C}$ diminui significativamente para as misturas modificadas (aproximadamente 50\%) em relação às convencionais. Em relação ao módulo de resiliência, a mistura convencional atingiu valores até 3 vezes maiores que as com asfaltos modificados, indicando dessa maneira, que a adição de borracha e de óleo extensor produzem misturas mais flexíveis. 
A redução significativa na resistência à tração encontrada por Pinheiro et al. (2003) nas misturas com asfalto-borracha também foi verificada por Faxina (2002), que aponta valores de RT de mistura asfalto-borracha 40\% menores que o valor de referência. Outros estudos chegaram a conclusões semelhantes também para misturas feitas com asfalto-borracha pelo processo úmido (Momm e Salini, 2000; Specht et al., 2003).

Pinheiro et al.(2003) compararam, em sua pesquisa, alguns parâmetros mecânicos de misturas asfálticas com incorporação do ligante asfalto-borracha com $20 \%$ de borracha e $20 \%$ de óleo extensor em relação à mistura convencional (CAP 50/60). Os resultados mostraram que as misturas com borracha apresentam valores menores de resistência à tração e de módulo de resiliência e uma maior vida de fadiga para baixos níveis de tensão, quando comparados a uma mistura convencional. Os autores acreditam que a alta viscosidade e o elevado teor do ligante asfalto-borracha são os prováveis motivos da redução do intertravamento entre os agregados e conseqüente redução dos valores dos parâmetros analisados, enquanto que o melhor desempenho à fadiga para baixas tensões deve-se, provavelmente, à capacidade do ligante modificado por borracha em impedir a propagação de trincas.

Nos estudos de Lemes (2004) foi avaliado o desempenho mecânico de misturas asfálticas densas submetidas ao processo de envelhecimento em curto prazo. A avaliação foi realizada com três tipos de cimentos asfálticos: CAP 20 (puro), cimento asfáltico modificado com polímero SBS (Styrene Butadiene Styren) e cimento asfáltico modificado com borracha reciclada de pneu (BRP). Os resultados, referentes ao ensaio de fluência, mostraram que as misturas modificadas apresentaram deformação total menor que as convencionais, no entanto, não foi possível, através do ensaio de módulo de resiliência, avaliar a influência do processo de envelhecimento na misturas modificadas com borracha.

Santos (2005), em seu estudo, avaliou o comportamento à fadiga de algumas misturas asfálticas modificadas com polímero SBS e borracha moída de pneu. Os resultados indicaram que, na maioria dos casos, as misturas com CAP $20+$ SBS apresentaram melhor desempenho (maior vida de fadiga), seguida da mistura com adição de $20 \%$ de borracha e, por último, da mistura de referência.

Segundo Oda et al. (2005), ao analisar o primeiro trecho experimental urbano com asfaltoborracha construído em dezembro de 2004 na cidade de Salvador, Bahia, utilizado em uma 
mistura asfáltica tipo SMA (Stone Matrix Asphalt) sem fibras, mostram que o revestimento com asfalto-borracha conferiu ganhos de atrito e drenabilidade superficial, garantindo, além disso, boa visibilidade e redução da aquaplanagem em dias de chuva, tornando o pavimento mais seguro e confortável.

Além de defeitos na superfície do pavimento, o ruído também é um problema para os usuários das vias. Quando em excesso é um dos problemas ambientais que afetam o bem estar da comunidade e, por isso, têm-se estudado misturas especiais que proporcionem melhoras no desempenho acústico das rodovias. Tais misturas podem ser stone matrix asphalt (SMA), camada porosa de atrito (CPA) ou gap-graded (granulometria descontínua), feitas com ligantes asfálticos especiais, modificados por polímeros ou por borracha de pneu moído (NASCIMENTO, et al. 2005). O mesmo autor realizou estudos em trechos de rodovias de São Paulo e concluiu que a utilização de misturas asfálticas tipo gap-graded (descontínuas), com asfalto-borracha, tornaram os pavimentos mais silenciosos e seguros quando comparados a pavimentos revestidos com misturas asfálticas densas convencionais.

\subsection{Ensaios de Propriedades Mecânicas}

O objetivo dos ensaios de laboratório é proporcionar o entendimento do comportamento mecânico dos materiais em campo, considerando que ensaios "in situ", muitas vezes, são de difícil realização. Os ensaios têm a finalidade de reproduzir, o mais próximo possível, as características e situações de campo, isto é, temperatura, grau de compactação, tempo de carregamento, níveis de tensões, entre outros. Porém essas condições, em campo, sofrem constantes mudanças, tornando, dessa maneira, as decisões referentes às condições de ensaio uma tarefa não trivial.

A caracterização mecânica das misturas asfálticas utilizadas no presente estudo foram realizadas segundo ensaios de Resistência à Tração por compressão diametral (DNER-ME 138/94), Módulo de Resiliência (DNER-ME 133/94 e ASTM D 4123, 1982) e resistência ao dano por umidade induzida (ASTM D 4867). 


\subsubsection{Ensaio de Resistência à Tração por compressão diametral}

O ensaio de Resistência à Tração por compressão diametral (RT) foi desenvolvido pelo professor Lobo Carneiro, em 1943, para avaliar misturas de cimento Portland e posteriormente passou a ser utilizado também para misturas asfálticas (MEDINA \& MOTTA, 2005).

O ensaio de resistência à tração por compressão diametral permite a determinação da resistência à tração de corpos de prova cilíndricos de misturas asfálticas, e consiste na aplicação progressiva de uma carga quase estática de compressão distribuída ao longo de duas geratrizes diametralmente opostas até a ruptura, por separação das duas metades do corpo-deprova segundo o plano diametral vertical, conforme Figura 1.1.
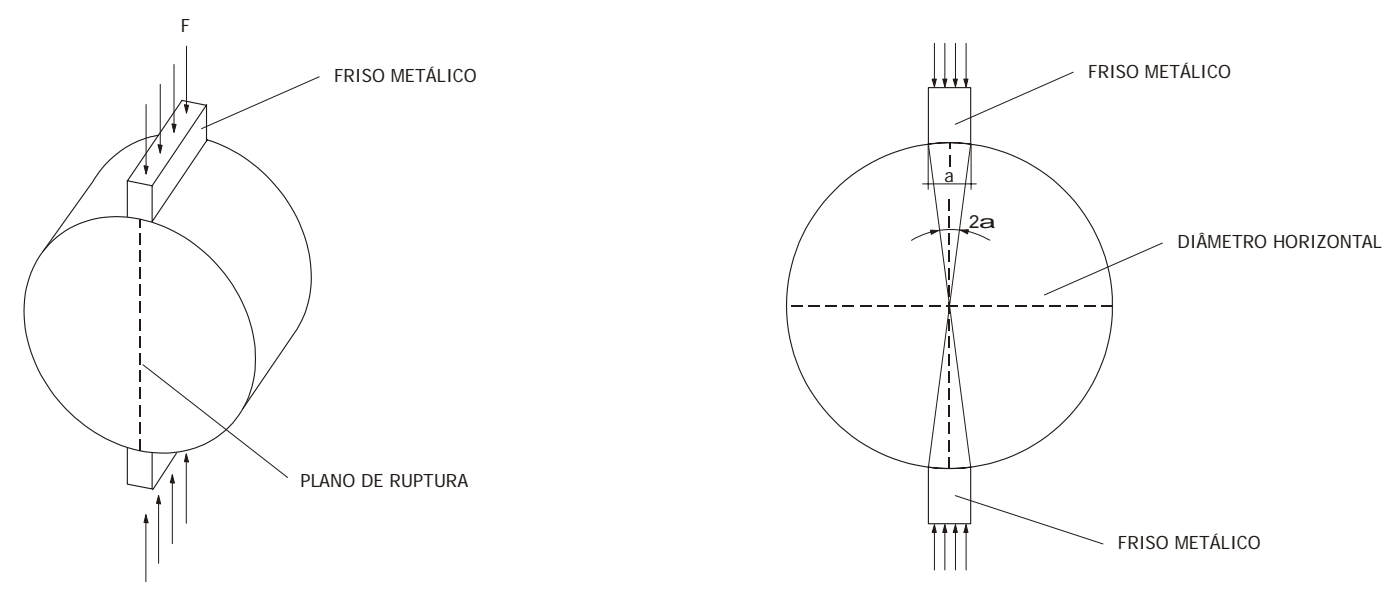

Figura 2.1: Ensaio de tração indireta em amostra cilíndrica.

No ensaio de RT à compressão diametral, a força $\mathrm{F}$ aplicada nos corpos-de-prova se dá através de frisos metálicos, produzindo tensão de tração ao longo do diâmetro vertical solicitado (perpendicular a ele) até que ela se iguale a tensão de tração admissível $(\sigma \mathrm{t}=\sigma \mathrm{adm})$ provocando o rompimento do corpo-de-prova.

O método de ensaio ME 138/94 apresenta o procedimento para a realização deste ensaio. Em linhas gerais, deve ser realizado da seguinte maneira:

- Mede-se altura $(\mathrm{H})$ e diâmetro do corpo-de-prova em três posições e utiliza-se a média das três leituras realizadas; 
- Acomoda-se o corpo-de-prova em local apropriado para a obtenção da temperatura especificada para o ensaio;

- Monta-se o corpo de prova no dispositivo de ruptura, acomodando-o sobre e sob os frisos de aplicação de carga;

- Ajusta-se o prato da prensa até que seja obtida uma leve compressão, capaz de manter em posição o corpo-de-prova; e

- Aplica-se a carga progressivamente, com uma velocidade de deslocamento do prato de $0,8 \pm 0,1 \mathrm{~mm} / \mathrm{s}$, até que se dê a ruptura, por separação das duas metades do corpo-deprova, segundo o plano diametral vertical; com o valor de carga de ruptura (F) obtido, calcula-se a resistência à tração do corpo-de-prova segundo a expressão 2.1:

$$
R T=\frac{2 F}{\pi d h}
$$

onde:

$\mathrm{RT}$ : resistência à tração indireta, $\mathrm{MPa}$;

$\mathrm{F}$ : carga de ruptura, $\mathrm{N}$;

d: diâmetro do corpo-de-prova, cm;

h: altura do corpo-de-prova, $\mathrm{cm}$.

\subsubsection{Módulo de Resiliência por compressão diametral dinâmica}

O ensaio para a determinação do módulo de resiliência (MR) visa simular o comportamento mecânico da mistura asfáltica, na zona onde ocorrem deformações de tração, responsáveis pela fadiga da camada (MOURÃO, 2003). Dentre as diversas maneiras de determinação do módulo de resiliência, a mais comum no Brasil para misturas asfálticas é aquela em que o corpo-de-prova é submetido à tração indireta por compressão diametral sob ação de cargas dinâmicas (ou repetidas).

De acordo com DNER (1994), o módulo de resiliência de misturas asfálticas é a relação entre a tensão de tração aplicada repetidamente no plano diametral vertical de uma amostra cilíndrica e a deformação específica recuperável correspondente à tensão aplicada, para uma dada temperatura. O ensaio é realizado por compressão diametral com frisos de carga, com 
aplicação de carga durante $0,1 \mathrm{~s}$ e repouso de $0,9 \mathrm{~s}$. A importância deste ensaio está atrelada ao fato do mesmo ser utilizado para o cálculo de tensões e deformações atuantes nos pavimentos e para seu dimensionamento. Entretanto, a norma brasileira não distingue deformação específica instantânea de deformação específica total, como a norma americana (ASTM D 4123, 1982).

O módulo de resiliência das misturas asfálticas foi obtida mediante ensaio de compressão diametral dinâmica, ou ensaio de tração indireta, realizado conforme a norma DNER-ME 133/94 (DNER, 1994), a qual determina o cálculo do módulo de resiliência de acordo com a fórmula 2.2:

$$
M r=\frac{F}{100 \Delta h}(0,9976 \mu+0,2692)
$$

em que:

$M r=$ é o módulo de resiliência, em MPa;

F é a carga vertical repetida aplicada diametralmente ao corpo de prova, em N;

$\Delta$ é o deslocamento (correspondente ao deslocamento elástico ou resiliente sofrido pelo corpo de prova, em direção perpendicular à aplicada da carga), em mm;

$h$ é a altura do corpo-de-prova, em mm;

$\mu$ é o coeficiente de Poisson (utilizado 0,35).

O DNER ME 133/94 normaliza a determinação do módulo de resiliência total, enquanto outras normas (ASTM D4123, ASSHTO TP-31, e a pesquisa 1-28 do NCHRP) mencionam dois módulos de resiliência, chamado total e instantâneo. O método da norma brasileira só considera as deformações totais e, por isso, só define o módulo total. Para a norma da AASHTO, o deslocamento total é obtido pela diferença entre o deslocamento máximo do ciclo de carregamento e o deslocamento registrado no final do ciclo, conforme mostra a Figura 2.2 . 


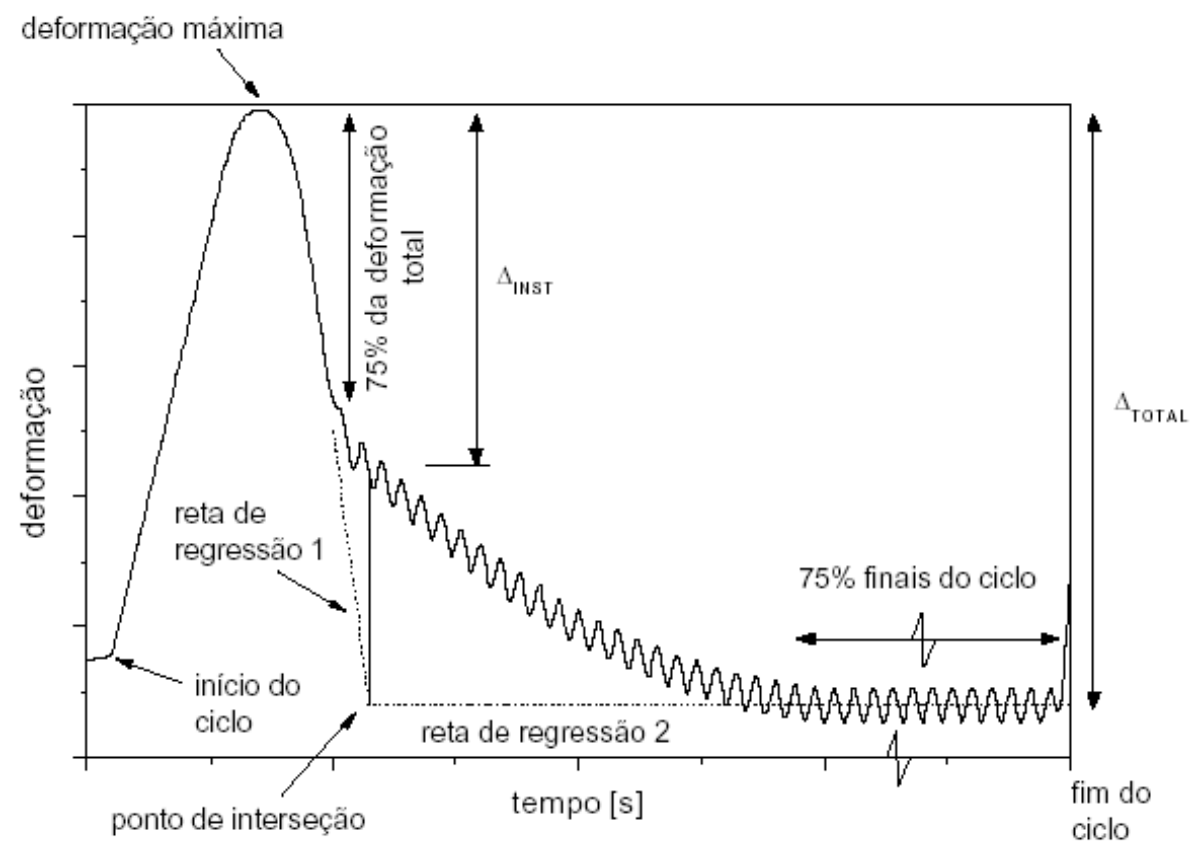

Figura 2.2. Curva de deformação x tempo, para um ciclo de carregamento. FONTE: AASHTO (1994) - AASHTO TP31-94.

O módulo de resiliência total (MRt) é calculado a partir da deformação resiliente total ( $\left.\Delta_{\text {Total }}\right)$, que é a junção da deformação que é recuperada instantaneamente e a deformação recuperada durante a fase do ciclo em que o corpo-de-prova não está sob carregamento, ou seja, em descanso. A deformação total é a diferença entre a deformação máxima do ciclo de carregamento e a deformação final, determinada pela média dos valores de deformação dos últimos $75 \%$ do ciclo.

O módulo de resiliência instantâneo é calculado com a deformação recuperada instantaneamente na fase de descarregamento do ciclo, não incluindo a deformação recuperada ao longo do tempo. Portanto, a deformação instantânea $\left(\mathrm{MR}_{\mathrm{i}}\right)$ é a diferença entre a deformação máxima atingida pelo corpo-de-prova num ciclo e a deformação na base do trecho de descarregamento da curva de deformação. Essa deformação é determinada a partir do ajuste de duas regressões lineares, uma na porção de descarregamento (reta 1) e a outra na porção de repouso (reta 2).

A reta 1 baseia-se em todos os pontos localizados depois do pico da curva e antes da recuperação de $75 \%$ da deformação máxima sofrida. A outra reta tem como base os pontos correspondentes aos últimos $0,75 \mathrm{~s}$ do ciclo. Estas duas retas de regressão se interceptam, e 
partindo-se desse ponto com uma reta vertical em direção à curva obtém-se o ponto que delimita o deslocamento resiliente instantâneo.

Vale ressaltar que para o NCHRP, o deslocamento total é obtido pela diferença entre o deslocamento máximo do ciclo de carregamento e a média dos deslocamentos registrados no intervalo de 85 a 95\% da porção de repouso do ciclo. Já a determinação do MRi é mais complexa devido à utilização de regressões hiperbólicas,conforme mostra a Figura 2.3, objetivando minimizar dispersões na determinação dos deslocamentos instantâneos, no entanto, apresenta princípio similar ao anterior.

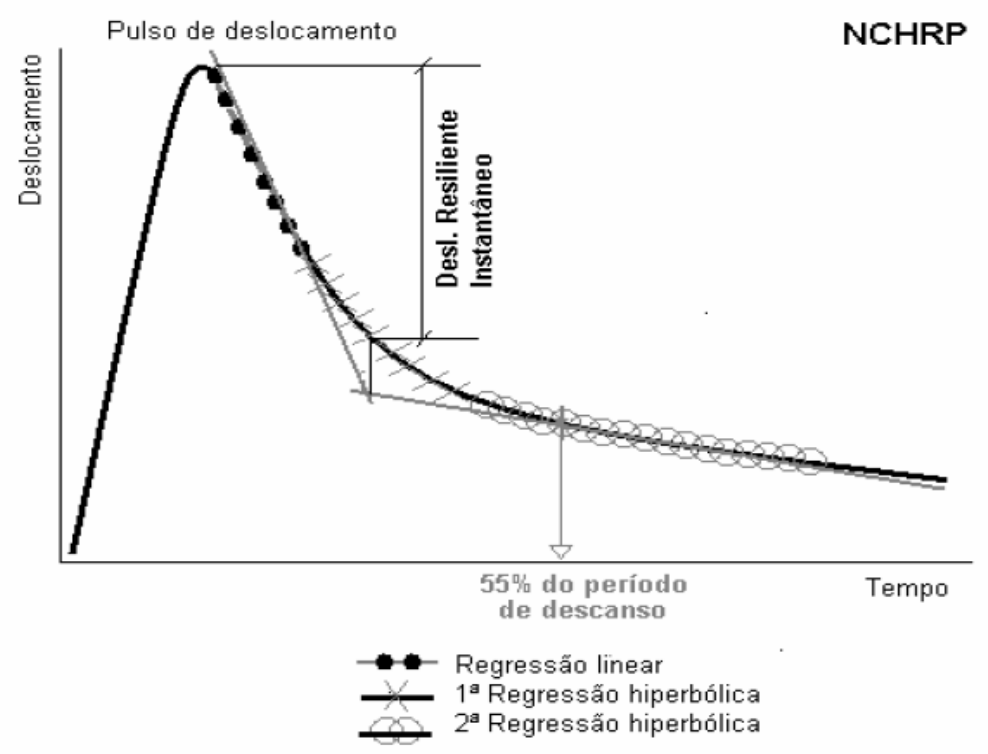

Figura 2.3. Curva de deformação para um ciclo de carregamento (NCHRP).

FONTE: FURLAN (2006)

O cálculo do deslocamento resiliente instantâneo é feito pela diferença entre o deslocamento máximo e uma ponta na região da porção da curva, compreendida por uma hipérbole, que é definido pela intersecção entre a reta de regressão que reproduz o descarregamento e uma reta de regressão que tangencia uma hipérbole que assimila a porção final da recuperação no tempo $\mathrm{t}=5 \mathrm{~s}$.

Também é possível avaliar outros parâmetros por meio do ensaio de módulo de resiliência: recuperação retardada e atraso. A recuperação retardada (RR), definida por Furlan, (2006), corresponde à recuperação no período de repouso e é indiretamente relacionada com a viscoelasticidade do material. Através do valor do RR verifica-se alterações de comportamento das misturas asfálticas quanto à forma resiliente, da mesma maneira que pode-se constatar se um 
aumento do valor do módulo de resiliência implicou em misturas asfálticas mais elásticas ou mais viscosas. Calcula-se esse parâmetro pela expressão 2.3 e 2.4 .

$$
\begin{gathered}
R R=\frac{\left(M R_{i}-M R_{T}\right)}{M R_{i}} \times 100 \\
R R=\frac{\varepsilon_{T}-\varepsilon_{i}}{\varepsilon_{T}} \times 100
\end{gathered}
$$

onde:

$\mathrm{RR}=$ recuperação retardada, em \%;

$\mathrm{MR}_{\mathrm{i}}=$ módulo instantâneo, em MPa;

$\mathrm{MR}_{\mathrm{t}}=$ módulo total, em MPa;

$\sigma=$ tensão aplicada;

$\varepsilon_{\mathrm{T}}=$ deformação total;

$\varepsilon_{\mathrm{i}}=$ deformação elástica instantânea.

\subsubsection{Dano por Umidade Induzida}

Geralmente o fator que mais contribui para originar problemas nas misturas asfálticas é a água, que atua de forma diferenciada, porém sempre danosa, e, portanto, na maioria dos métodos a água é vista como agente causador do dano à mistura, juntamente com as variações térmicas e/ou carregamentos cíclicos. Os danos por umidade induzida não se caracterizam como um modo de ruptura, mas sim como um processo condicionante, acelerado pela presença de água, que pode levar a mistura asfáltica à ruptura por facilitar o aparecimento de outros defeitos, como: afundamento em trilhas de roda, trincas por fadiga e/ ou desagregação (FURLAN, 2006).

Muitos fatores afetam o grau de danos provocados pela umidade em misturas de concreto asfáltico. Fatores como temperatura, ar, água, pode ter profundo efeito em sua durabilidade. Em regiões com climas amenos, onde a qualidade dos agregados e do cimento asfáltico é boa, a deterioração é oriunda, principalmente, da contribuição das cargas do tráfego e dos defeitos manifestados na forma de trincamento por fadiga e desgaste superficial (GALVÃO, 2001). 
Esse mesmo autor comenta que o efeito adverso da água nas misturas asfálticas é devido à ocorrência do deslocamento da película de asfalto que recobre os agregados pela ação da água. As conseqüências desse efeito podem ser:

- Arrancamento de agregados da superfície do revestimento;

- Perda geral da estabilidade da mistura em decorrência da abertura de panelas localizadas e degradação da mistura;

- Trincamento por fadiga prematura, associada à perda de capacidade estrutural do revestimento asfáltico resultante da lavagem da película de asfalto dos agregados situados nas porções inferiores da camada asfáltica.

Os condicionamentos realizados nas misturas asfálticas têm como objetivo simular o meio ao qual elas estarão expostas ao longo do tempo e causar, com essas simulações, alterações nas suas propriedades, que, por sua vez, podem ser avaliadas por ensaios de propriedades mecânicas. Nos casos dos métodos tradicionais, a variação das propriedades mecânicas é avaliada, principalmente, por meio do ensaio de resistência à tração (FURLAN, 2006).

Para a avaliação do dano por umidade induzida as misturas asfálticas são submetidas a algum tipo de condicionamento e são comparadas com misturas que não passaram por esse processo, ou seja, misturas não-condicionadas. O condicionamento que vem sendo utilizado baseia-se na saturação parcial de corpos-de-prova, normalmente, mediante aplicação de vácuo para indução da entrada de água. Depois de atingida a saturação desejada, submete-se os corposde-prova a condicionamentos térmicos que simulem tensões e/ou temperaturas.

Um dos métodos de ensaio para avaliação da umidade induzida é baseado na norma AASHTO T283, que recomenda algumas condições para preparação dos corpos-de-prova, como o envelhecimento da mistura não compactada por um período de $16 \mathrm{~h}$ a $60^{\circ} \mathrm{C}$; a compactação deve ser realizada de tal maneira que resulte em volume de vazios de $7 \pm 1 \%$ ou iguais ao do pavimento em serviço, além de, saturar parcialmente com água os vazios. Para a saturação é utilizada uma bomba de vácuo na pressão de 26 ” $\mathrm{Hg}$, que proporciona a entrada de água. Depois de atingida a saturação desejada, que deve estar no intervalo de 55 a $80 \%$, faz-se o condicionamento térmico, composto por um ciclo de congelamento, onde se coloca o corpo-de-prova a $-18^{\circ} \mathrm{C}$ por $16 \mathrm{~h}$, e um de descongelamento, com a imersão em água a $60^{\circ} \mathrm{C}$ por $24 \mathrm{~h}$. 
Outro método de ensaio para a determinação da resistência de misturas asfálticas ao dano por umidade induzida é a norma D 4867, da ASTM, que estabelece que para a saturação parcial do corpo-de-prova compactado seja utilizada uma bomba de vácuo que produz vácuo de 26 " $\mathrm{Hg}$, para propiciar a entrada da água. Posteriormente à saturação desejada, que deve estar no intervalo de 55 a $80 \%$, o condicionamento térmico é realizado, sendo composto por um ciclo de imersão, a $60^{\circ} \mathrm{C}$, por $24 \mathrm{~h}$, e um de estabilização, que consiste da imersão em água a $25^{\circ} \mathrm{C}$ por $1 \mathrm{~h}$.

Os resultados dos ensaios associam os danos por umidade induzida a uma idade do pavimento, sendo que o ensaio executado segundo a norma AASHTO T283 representa de 4 a 12 anos e segundo a ASTM D4867 de 0 a 4 anos, devido aos tipos de condicionamentos aos quais as misturas são submetidas e pode-se classificá-los como ensaio de dano por umidade induzida em longo prazo (AASHTO T283) e a curto prazo (ASTM D4867) (FURLAN, 2006).

A suscetibilidade à umidade induzida é então expressa pela relação entre os valores, em termos médios, das propriedades medidas para o conjunto de corpos-de-prova condicionado em relação ao conjunto não condicionado, ou de controle, conforme a expressão 2.5.

$$
R R T=\frac{\overline{R T_{1}}}{{\overline{R T_{2}}}_{2}} \times 100
$$

onde:

RRT=relação de resistência à tração (\%);

$\mathrm{RT}_{1}=$ resistência à tração média do grupo condicionado;

$\mathrm{RT}_{2}=$ resistência à tração média do grupo de controle.

O critério de definição da suscetibilidade de uma mistura asfáltica, referente à norma ASTM D4867, é de RRT > 70\% (TUNNICLIFT e ROOT², 1995 apud FURLAN, 2006). Para a norma da AASHTO T283/89 o critério é de RRT > 70\% e para AASHO T283/99 é de RRT > $80 \%$.

\footnotetext{
2 TUNNICLIFF, D.G; ROOT, R.E (1995). NCHRP Report 373. Use of Antistripping Additives in Asphalt Concrete Mixtures - Field Evaluation Transportation research Board, National Research Council, Washington, D.C.
} 


\section{Capítulo 3}

\section{MATERIAIS E MÉTODOS}

Nesse capítulo são descritos o planejamento estatístico do experimento, os conjuntos de ensaios selecionados para caracterização da borracha, do agregado mineral, dos ligantes e das misturas asfálticas. Da mesma maneira, serão apresentados os procedimentos para a coleta e caracterização dos materiais, dosagem das misturas asfálticas, moldagem e caracterização dos corpos-de-prova e a execução do ensaio de módulo de resiliência. Cabe ressaltar que os procedimentos referentes aos ligantes e o planejamento do experimento estão descritos em FAXINA (2006).

\subsection{Planejamento do experimento}

O experimento, que tem como finalidade analisar o comportamento de misturas asfálticas com adição de óleo de xisto e borracha moída de pneu, é composto pela moldagem de corpos-deprova para realização de ensaios de laboratório. A escolha do conjunto de ensaios permitiu o acompanhamento das características físicas de amostras preparadas de acordo com o delineamento do experimento. Mediante os dados obtidos foi realizada uma análise estatística, com objetivo de obter conclusões referentes ao efeito do resíduo do óleo de xisto nas misturas asfálticas com asfalto-borracha dosadas nesse trabalho.

O processo de avaliação foi experimental e possuiu as seguintes etapas: 1- mediante a teoria de experimentos com misturas foram definidas e preparadas as amostras em laboratório; 2- foi realizado o monitoramento das propriedades físicas das amostras; 3- feita a modelagem estatística e; 4-análise de efeitos dos componentes e da superfície de resposta.

O experimento foi delineado com base na técnica estatística de "experimentos com misturas" (Cornell, 2002). A partir dos resultados obtidos foram ajustados modelos do tipo polinomial e, com base nos modelos adotados, foram efetuadas análises de efeitos do componentes (teor e tipo de asfalto - puro, com borracha, com óleo e com óleo e borracha) e de superfície de resposta nas propriedades monitoradas. 
A técnica de planejamento de experimentos com misturas é uma técnica estatística utilizada em várias áreas, podendo ser aplicada em experimentos nos quais seja possível atribuir as modificações de propriedades das amostras a variações nas proporções dos seus componentes. No presente trabalho, as amostras são chamadas "misturas" e os fatores considerados na análise global do experimento são denominados "componentes". Fatores associados ao processamento da mistura, com capacidade semelhante à dos componentes de promover alterações nas propriedades das amostras, são denominados "fatores de processo" ou "variáveis de processo".

A abordagem de um problema experimental por meio da técnica de experimentos com misturas prevê que as variáveis ou fatores escolhidos para descrever o fenômeno em questão sejam proporções, o que cria a condição de dependência entre os níveis dos fatores. Dessa maneira, a técnica de planejamento fatorial teoricamente não se aplica a estudos da natureza do realizado nesta pesquisa, já que exige que as variáveis sejam independentes.

Para tentar conciliar os objetivos da pesquisa com as restrições de tempo, de equipamentos e de recursos financeiros, foi decidido fixar a maioria das variáveis intervenientes sobre as características do ligante asfalto-borracha e a variação apenas da concentração dos componentes. Optou-se pela utilização de apenas um tipo de ligante asfáltico, de borracha moída e de óleo aromático, visto que a avaliação do efeito de componentes com outras características aumentaria o número de novos componentes, deixando a pesquisa mais trabalhosa.

Assim, a pesquisa avaliou o efeito da presença ou não, de três componentes nas misturas, a saber: o ligante asfáltico, a borracha moída e o resíduo de óleo de xisto, que serão referenciados no trabalho como asfalto, borracha e óleo, respectivamente. A composição desses materiais pode originar três tipos de misturas: primárias, binárias e terciárias, ou seja, a presença de apenas um, dois ou três componentes, respectivamente. A quantidade de cada componente deve ser maior ou igual a zero e o somatório das proporções de todos eles deve ser igual à unidade.

Para esse estudo, as misturas possíveis são:

- primárias: asfalto;

- binárias: asfalto+borracha e asfalto+óleo; 
- ternárias: asfalto+borracha+óleo.

As "restrições" do experimento são definidas com base na experiência do experimentador e/ou no seu conhecimento sobre o possível comportamento das misturas em estudo. Considerando as características do asfalto e da borracha em questão, foram escolhidas as seguintes restrições para os três componentes:

$$
\begin{gathered}
0,68 \leq \mathrm{x}_{1} \leq 1,00 \text { (asfalto) } \\
0,00 \leq \mathrm{x}_{2} \leq 0,18 \text { (borracha) } \\
0,00 \leq \mathrm{x}_{3} \leq 0,14 \text { (óleo) }
\end{gathered}
$$

A teoria de planejamento de experimentos com misturas também orientou a seleção das misturas que servem de base para a descrição do espaço amostral que resultaram das restrições impostas, visto que essa é a principal finalidade da técnica de delineamento de experimentos. No sistema de três componentes, uma região poligonal deve ser formada pelas restrições, e as misturas a serem avaliadas devem estar localizadas, por ordem de prioridade, nos vértices, nos pontos médios dos lados e no centro geométrico da figura.

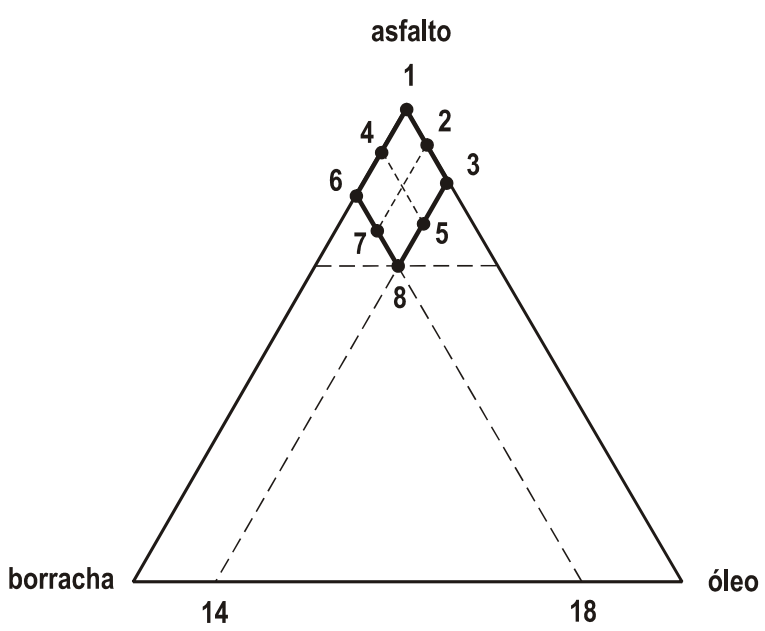

Figura 3.1: Simplex formado pelos três componentes e espaço amostral com restrições.

(FONTE: FAXINA, 2006).

É necessário selecionar um número mínimo de misturas, sendo suficientes para um bom detalhamento do espaço amostral, e também para dar suporte ao modelo estatístico escolhido para descrever o fenômeno. As amostras são determinadas com base nas restrições de teores dos componentes e no grau do modelo a ser ajustado. O mais comum, em planejamento com mistura, 
é utilizar modelos polinomiais de grau um, dois ou três (cúbico completo ou cúbico especial). Para esse trabalho, foi delimitado o espaço amostral conforme Figura 3.1 e foram selecionadas 8 misturas, como mostra a Figura 3.2 e Tabela 3.1. O modelo escolhido para descrever o espaço amostral foi o polinomial de terceiro grau do tipo cúbico especial.

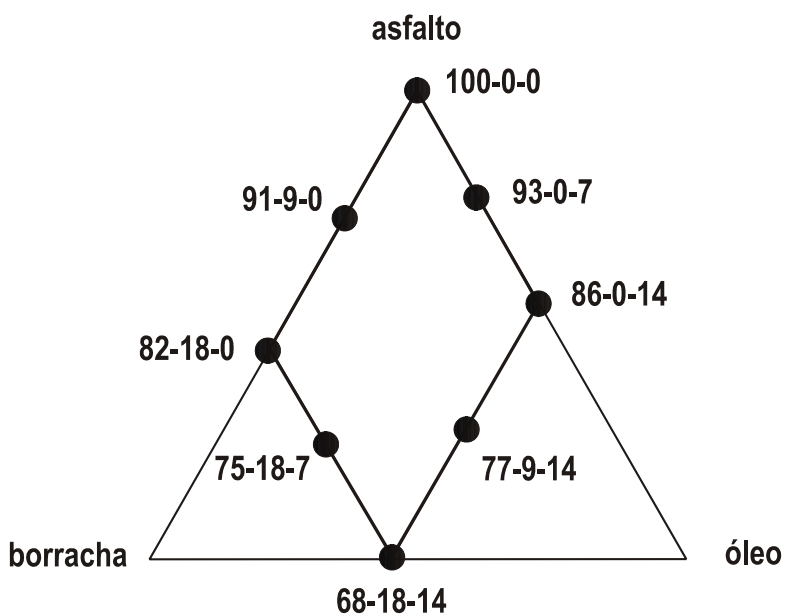

Figura 3.2. Espaço amostral com restrições e misturas escolhidas.

(FONTE: FAXINA, 2006).

Tabela 3.1. Proporções dos componentes das misturas selecionadas.

\begin{tabular}{cccc}
\hline Identificação & \multicolumn{3}{c}{ porcentagem dos componentes } \\
\cline { 2 - 4 } da Mistura* & asfalto & borracha & óleo de xisto \\
\hline $100-0-0$ & 100 & 0 & 0 \\
$91-9-0$ & 91 & 9 & 0 \\
$82-18-0$ & 82 & 18 & 0 \\
$93-0-7$ & 93 & 0 & 7 \\
$75-18-7$ & 75 & 18 & 7 \\
$77-9-14$ & 77 & 9 & 14 \\
$68-18-14$ & 68 & 18 & 14 \\
\hline
\end{tabular}

*A identificação das misturas foi feita com base na porcentagem dos componentes; assim, o primeiro número corresponde ao teor de asfalto, o segundo ao teor de borracha e o terceiro ao teor de óleo de xisto. A mistura 100-0-0 é o asfalto de base (CAP 30/45).

O agregado mineral, no delineamento do experimento, não é considerado um quarto componente, pois tornaria o experimento mais complexo e a seleção das amostras deveria ser realizada mediante outro procedimento. Devido à porcentagem de agregado no corpo-de- 
prova não ser alterada $(1200 \mathrm{~g})$ e à definição de cada modelo ser realizada para teores controlados de ligante asfáltico, assume-se que as porcentagens de agregado e de ligante asfáltico são constantes nas 8 misturas para cada teor de ligante asfáltico. Dessa maneira, é possível avaliar o efeito das variações dos teores de asfalto, de borracha e de resíduo de óleo de xisto na misturas asfálticas, admitindo que as interferências sobre os valores das propriedades avaliadas sejam devidas somente às variações nas porcentagens desses componentes.

Para caracterizar os ligantes asfálticos foram selecionados os ensaios descritos na Tabela 3.2. Foram realizados ensaios para monitoramento das propriedades reológicas empíricas, por serem as mais utilizadas no Brasil, e também as fundamentais, pois essas proporcionam uma caracterização racional dos materiais. Já para avaliar os efeitos dos componentes em ligantes asfálticos envelhecidos foi realizado envelhecimento a curto e longo prazo da especificação Superpave.

Tabela 3.2. Propriedades físicas, temperaturas e métodos de ensaio, para os ligantes asfálticos avaliados no experimento.

\begin{tabular}{ccc}
\hline Propriedade & Temperatura $\left({ }^{\circ} \mathbf{C}\right)$ & Método de ensaio \\
\hline $\begin{array}{c}\text { resiliência virgem } \\
\text { ponto de amolecimento } \\
\text { virgem, RTFOT e PAV }\end{array}$ & 25 & ASTM D 5329-96 \\
penetração virgem, RTFOT e & - & ASTM D 36-95 \\
PAV & 25 & ASTM D 5-05 \\
viscosidade aparente & 150 & ASTM D 4402-02 \\
$\begin{array}{c}\text { (Brookfield) virgem } \\
\text { balanço de massa }\end{array}$ & 163 & ASTM D 2872-97 \\
\hline
\end{tabular}

A dosagem das misturas asfálticas foi realizada conforme método Marshall, considerando cinco teores de ligante asfáltico, sendo confeccionados sete corpos-de-prova por teor, que também foram usados nos ensaios para obtenção das propriedades mecânicas das misturas asfálticas. A composição granulométrica utilizada foi do tipo densa (centro da faixa $\mathrm{C}$ do DER-SP). A Tabela 3.3 indica os ensaios de caracterização mecânica das misturas asfálticas utilizados no experimento. 
Tabela 3.3. Propriedades mecânicas das misturas asfálticas avaliadas no experimento.

\begin{tabular}{lcc}
\hline \multicolumn{1}{c}{ Propriedade } & Temperatura $\left({ }^{\circ} \mathbf{C}\right)$ & Método de ensaio \\
\hline Resistência à tração & 25 & DNER-ME 138/94 \\
Módulo de resiliência & 25 & ASTM D 3497-79 (2003) \\
Dano induzido pela umidade* & 25 & ASTM D 4867-95 \\
\hline
\end{tabular}

*avaliado mediante ensaios de resistência à tração e de módulo de resiliência.

\subsection{Materiais Utilizados}

\subsubsection{Materiais granulares}

Os materiais utilizados na pesquisa são o ligante asfáltico, a borracha moída, o resíduo de óleo de xisto e o agregado mineral. Os agregados minerais foram fornecidos pela Pedreira Said, de Ribeirão Preto, SP, obtidos mediante britagem de rocha basáltica. A Tabela 3.4 indica a faixa granulométrica escolhida para este estudo, que corresponde à faixa $\mathrm{C}$ do DER-SP, assim como as distribuições granulométricas dos materiais granulares e da composição final dos agregados. A Figura 3.3 apresenta a faixa granulométrica adotada e distribuição granulométrica da mistura de agregados.

Tabela 3.4. Limites da faixa "C" do DER/SP e composição granulométrica da mistura final

\begin{tabular}{cccc}
\hline peneiras & \multicolumn{3}{c}{ faixa C - DER/SP (\% passada) } \\
\hline $\mathbf{( m m})$ & limite & limite & centro da faixa \\
\hline 19,0 & 100 & 100 & 100,0 \\
\hline 12,5 & 85 & 100 & 92,5 \\
\hline 4,8 & 50 & 80 & 65,0 \\
\hline 2,0 & 30 & 65 & 47,5 \\
\hline 0,42 & 15 & 40 & 27,5 \\
\hline 0,175 & 10 & 25 & 17,5 \\
\hline 0,075 & 6 & 10 & 8,0 \\
\hline
\end{tabular}




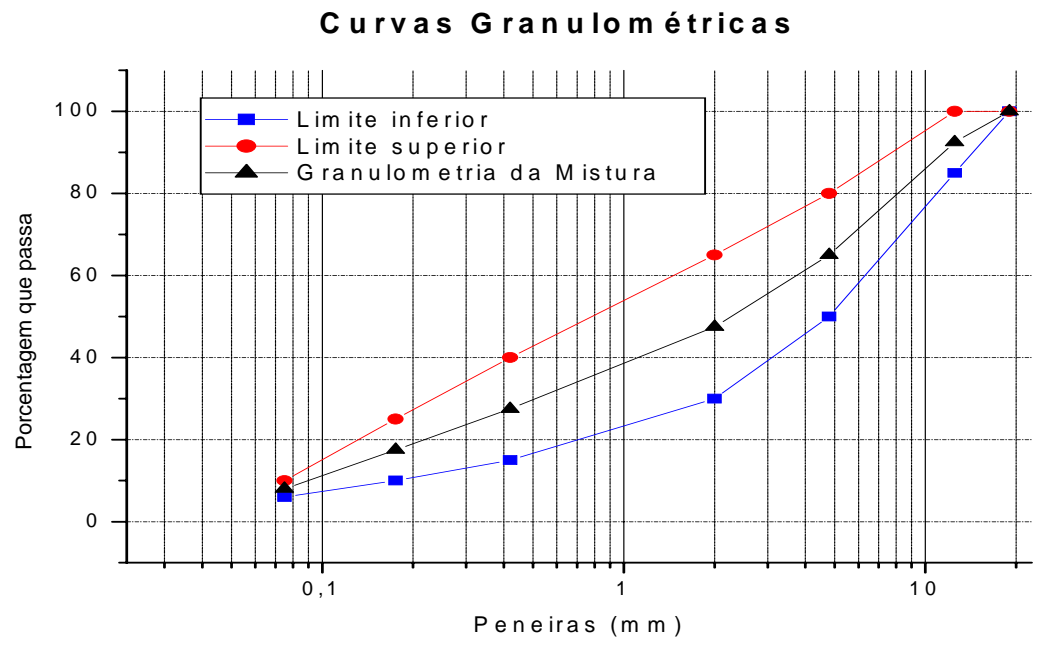

Figura 3.3. Faixa C do DER/SP (DER/SP, 1991) e curva granulométrica da mistura obtida.

\subsubsection{Determinação das propriedades dos agregados}

Para determinação das propriedades físicas dos agregados foram realizados os seguintes ensaios:

1. Abrasão Los Angeles (DER/SP M35/94);

2. Densidade aparente, real e absorção do agregado miúdo (ASTM C 128-93);

3. Densidade aparente, real e absorção do agregado graúdo (ASTM C 127-01).

\section{Abrasão Los Angeles}

Os agregados estão sujeitos a esforços adicionais de esmagamento e abrasão durante a fabricação, espalhamento e compactação das misturas asfálticas. Os agregados também estão sujeitos à abrasão sob ação das cargas do tráfego. Espera-se então que o agregado tenha capacidade de resistir a esmagamento, degradação e desintegração.

Abrasão "Los Angeles" do agregado é o desgaste sofrido pelo agregado (pedra britada, pedrisco e pedregulho), quando colocado na máquina "Los Angeles" juntamente com uma carga abrasiva, submetido a um determinado número de revoluções desta máquina à velocidade de $30 \mathrm{rpm}$ a $33 \mathrm{rpm}$. O desgaste é convencionalmente expresso pela porcentagem, em peso, do material que passa, após o ensaio, pela peneira de malhas quadradas de $1,7 \mathrm{~mm}$. 
A abrasão "Los Angeles" do agregado é calculada através da expressão:

$$
A_{N}=\frac{\left(m_{n}-m_{n}^{\prime}\right)}{m_{n}} * 100
$$

onde:

$\mathrm{A}_{\mathrm{n}}=$ abrasão "Los Angeles" da graduação n, com aproximação de 1\%;

$\mathrm{n}=$ graduação (A, B, C, D, E, F ou G) escolhida para o ensaio;

$\mathrm{m}_{\mathrm{n}}=$ massa total da amostra seca, colocada na máquina;

$\mathrm{m}_{\mathrm{n}}=$ massa da amostra lavada e seca, após o ensaio (retido na peneira de $1,7 \mathrm{~mm}$ ).

\section{Densidades aparente, real e absorção do agregado miúdo}

Esses ensaios foram realizados através da norma ASTM C128-93, que considera como agregado miúdo o material com partículas menores que $4,75 \mathrm{~mm}$.

Para determinação das densidades e da absorção foi lavado, inicialmente, $1000 \mathrm{~g}$ do material (passado na peneira de malha $2,36 \mathrm{~mm}$ e retido na peneira de malha $0,075 \mathrm{~mm}$ ). Posteriormente o material ficou imerso em água por 24 horas e, em seguida, foi colocado em uma superfície plana e exposto a uma corrente de ar quente para iniciar o processo de secagem. Após observar mudança de cor do agregado, uma amostra é colocada dentro do cone metálico para compactação com 25 golpes. Depois da compactação retira-se o cone lentamente para verificar a condição do agregado. A condição saturada seca superficialmente se dá quando parte ou todo o cone desmorona. Esse procedimento é realizado até que essa condição seja alcançada.

Depois de atingida a condição saturada seca superficialmente retira-se da amostra aproximadamente $500 \mathrm{~g}$, a qual é colocada em um kitassato para verificação da massa do conjunto (amostra + recipiente). Em seguida, adiciona-se água (destilada) ao conjunto até atingir um nível de água um pouco superior ao da superfície do agregado, então é aplicado um vácuo por 20 minutos com a finalidade de retirar as bolhas de ar. Feito isso, completa-se o conjunto com água e verifica-se a temperatura, para posterior pesagem do conjunto 
(amostra+recipiente+água). Finalmente o material é retirado e colocado na estufa a $100^{\circ} \mathrm{C}$, para determinação da massa da amostra seca.

As densidades e a absorção são determinadas pelas expressões que seguem:

Densidade aparente $=\rho_{a p}=\frac{S}{B+S-C}$

Densidade real $=\rho_{r}=\frac{A}{B+A-C}$

Absorção $=A(\%)=\frac{B-S}{S} * 100$

em que:

$\mathrm{S}=$ massa da amostra $(\mathrm{g})$;

$\mathrm{C}=$ massa do kitassato + amostra+água $(\mathrm{g})$;

$\mathrm{B}=$ massa do kitassato cheio de água, obtida através da curva de calibração $(\mathrm{g}) ; \mathrm{e}$ $A=$ massa da amostra seca $(g)$.

\section{Densidades aparente, real e absorção do agregado graúdo}

Este ensaio é realizado segundo a norma ASTM 127-01. Para a sua execução pesa-se $2 \mathrm{~kg}$ de material retido na peneira de malha 4,75mm após ser lavado e seco em estufa. Depois de ficar imerso por 24 horas em água, o material é retirado e secado até a condição de saturação com secagem superficial, com posterior pesagem. Em seguida, é obtido o peso imerso do material; e por fim o material é colocado na estufa até o peso estabilizar para se obter o valor do peso seco.

Neste caso as densidades são obtidas através das seguintes expressões:

Densidade aparente $=\rho_{a p}=\frac{A}{B-C}$ 
Densidade real $=\rho_{r}=\frac{A}{A-C}$

Absorção $=A(\%)=\frac{B-A}{A} * 100$

em que:

$\mathrm{A}=$ massa da amostra seca em estufa, determinada ao $\operatorname{ar}(\mathrm{g})$;

$\mathrm{B}=$ massa da amostra seca superficialmente, determinada ao ar $(\mathrm{g})$;

$\mathrm{C}=$ massa da amostra seca superficialmente, determinada quando imersa na água $(\mathrm{g})$.

Os valores obtidos dos ensaios relatados anteriormente estão apresentados na Tabela 3.5.

Tabela 3.5. Ensaios de caracterização física dos agregados minerais.

\begin{tabular}{lcc}
\hline \multicolumn{1}{c}{ Ensaio } & \multicolumn{1}{c}{ Método } & Resultado \\
\hline Abrasão Los Angeles, \% & DER/SP M35/64 & 11 \\
Densidade aparente do agregado miúdo & & 2,904 \\
Densidade real do agregado miúdo & ASTM C 128-93 & 2,933 \\
Absorção de água do agregado miúdo (\%) & & 0,32 \\
Densidade aparente do agregado graúdo & & 2,850 \\
Densidade real do agregado graúdo & ASTM C 127-01 & 2,965 \\
Absorção de água do agregado graúdo (\%) & & 1,030 \\
\hline
\end{tabular}

\subsubsection{Borracha}

A borracha moída foi fornecida pela empresa Artgoma do Brasil Ltda., de São Paulo, SP, sendo resultado do processo de trituração de rebarbas de recapagem de pneus de veículos pesados (caminhões e tratores). A análise granulométrica da borracha é apresentada na Tabela 3.6 e a curva granulométrica na Figura 3.4. O teor de umidade do material é 3\%. O ensaio de termo-gravimetria indicou a presença de 64,3\% de material orgânico, 31,4\% de negro de fumo e 4,3 \% de material inorgânico na composição química da borracha. 
Tabela 3.6. Distribuição granulométrica da borracha moída.

Abertura da peneira (mm) \% passada

\begin{tabular}{cc}
\hline 1,19 & 100,00 \\
0,59 & 99,24 \\
0,42 & 59,74 \\
0,297 & 44,99 \\
0,175 & 15,84 \\
0,150 & 11,31 \\
0,074 & 2,46 \\
Fundo & 0,00 \\
\hline
\end{tabular}

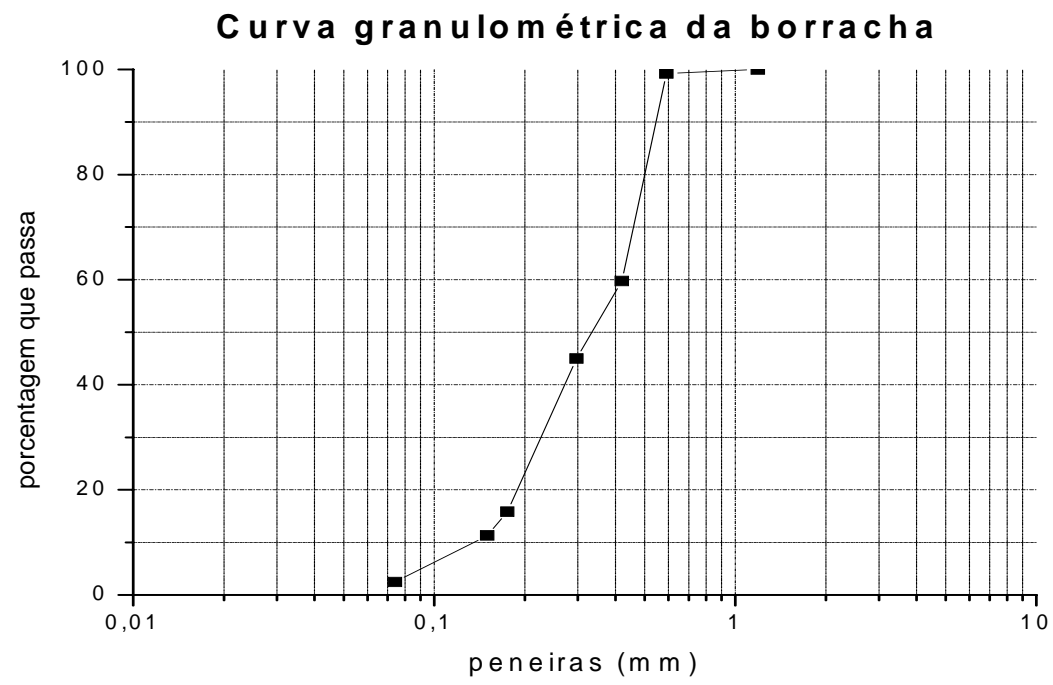

Figura 3.4. Curva granulométrica da borracha moída.

\subsection{3 Óleo Extensor}

O óleo extensor (AR-5), utilizado nesse estudo, obtido a vácuo do resíduo de óleo de xisto, foi fornecido pela Unidade de Negócios da Industrialização do Xisto (SIX - Petrobras), de São Mateus do Sul, PR. A Tabela 3.7 indica as características do AR-5. 
Tabela 3.7. Caracterização do agente rejuvenescedor de xisto AR-5

(Fonte: SIX-Petrobras)

\begin{tabular}{|c|c|c|c|}
\hline \multicolumn{2}{|c|}{ Características } & $\begin{array}{c}\text { Método de } \\
\text { ensaio }\end{array}$ & Valores \\
\hline \multicolumn{2}{|c|}{ Ponto de anilina ${ }^{1},{ }^{\circ} \mathrm{C}$} & ASTM D 611 & 31,5 \\
\hline \multirow{2}{*}{ Viscosidade absoluta, cSt } & $37,8^{\circ} \mathrm{C}\left(100^{\circ} \mathrm{F}\right)$ & \multirow{2}{*}{ ASTM D 2171} & 2.232 \\
\hline & $40^{\circ} \mathrm{C}\left(104^{\circ} \mathrm{F}\right)$ & & 1.756 \\
\hline \multicolumn{2}{|c|}{ Densidade } & - & 0,9969 \\
\hline \multicolumn{2}{|l|}{$\mathrm{VGC}^{2}$} & ASTM D 2501 & 0,2076 \\
\hline \multicolumn{2}{|c|}{ Viscosidade Saybolt Furol, sSF } & MB-517 & 15,32 \\
\hline \multicolumn{2}{|c|}{ Asfaltenos, $\%$ em peso } & ASTM D 2007 & 4,5 \\
\hline \multicolumn{2}{|c|}{ Ponto de fluide $z^{3},{ }^{\circ} \mathrm{C}$} & ASTM D 97 & +12 \\
\hline \multicolumn{2}{|c|}{ Ponto de fulgor, ${ }^{\circ} \mathrm{C}$} & MB-50 & 232 \\
\hline \multicolumn{2}{|c|}{ Carbono aromático, $\mathrm{NMR}^{4} \%$} & - & 36,9 \\
\hline
\end{tabular}

${ }^{1}$ Indica a capacidade de um óleo de dissolver certos materiais com os quais entra em contato. Corresponde à menor temperatura na qual o óleo é completamente miscível com igual volume de anilina. Produtos com alto ponto de anilina são ricos em hidrocarbonetos parafínicos e pobres em naftênicos e aromáticos.

2“Viscosity-gravity constant" (VGC): é uma estimativa da composição de hidrocarbonetos de um óleo. É obtida, segundo ASTM D 2501, pela seguinte equação: VGC a $37,8^{\circ} \mathrm{C}\left(100^{\circ} \mathrm{F}\right)=(10 \mathrm{G}-$ $1,0752 \log (\mathrm{V}-38)) / 10-\log (\mathrm{V}-38)$, onde: $\mathrm{G}=$ densidade a $15,6^{\circ} \mathrm{C}\left(60^{\circ} \mathrm{F}\right)$, e $\mathrm{V}=$ viscosidade SayboltFurol a $37,8^{\circ} \mathrm{C}\left(100^{\circ} \mathrm{F}\right)$. Valores de VGC próximos de 0,80 indicam óleo de características parafínicas e valores próximos de 1,00 indicam óleos com preponderância de hidrocarbonetos aromáticos.

${ }^{3}$ É a temperatura em que um óleo submetido a um processo de resfriamento pára de fluir. É um indicativo da sua capacidade de ser bombeado.

4 "Nuclear magnetic ressonance" - ressonância magnética nuclear.

\subsubsection{Cimento Asfáltico}

O cimento asfáltico empregado como base foi o CAP 30/45, com classificação PG 70-10 na especificação Superpave, tendo sido fornecido pela Refinaria Duque de Caxias (Reduc- 
Petrobrás). A Tabela 3.8 apresenta os resultados referentes à caracterização física do cimento asfáltico utilizado.

Tabela 3.8. Resultados de caracterização física do CAP 30/45.

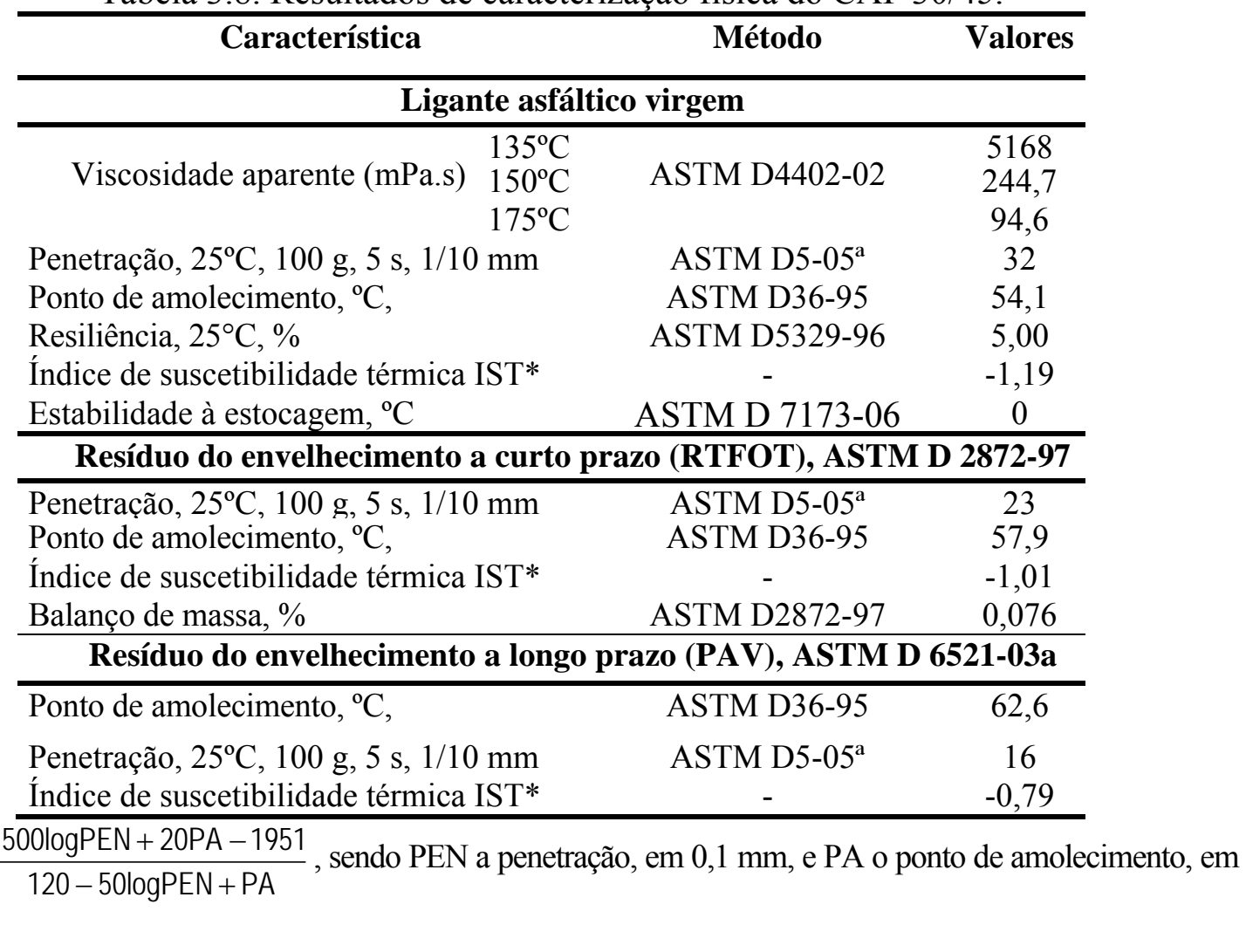

${ }^{\circ} \mathrm{C}$.

\subsubsection{Ligantes Modificados}

Os ensaios de caracterização física também foram realizados para os sete tipos de ligantes modificados estudados no presente trabalho. Os resultados dessas caracterizações estão apresentados nas Tabelas 3.9 a 3.15 . 
Tabela 3.9. Resultados de caracterização física do Ligante 2 (93-0-7).

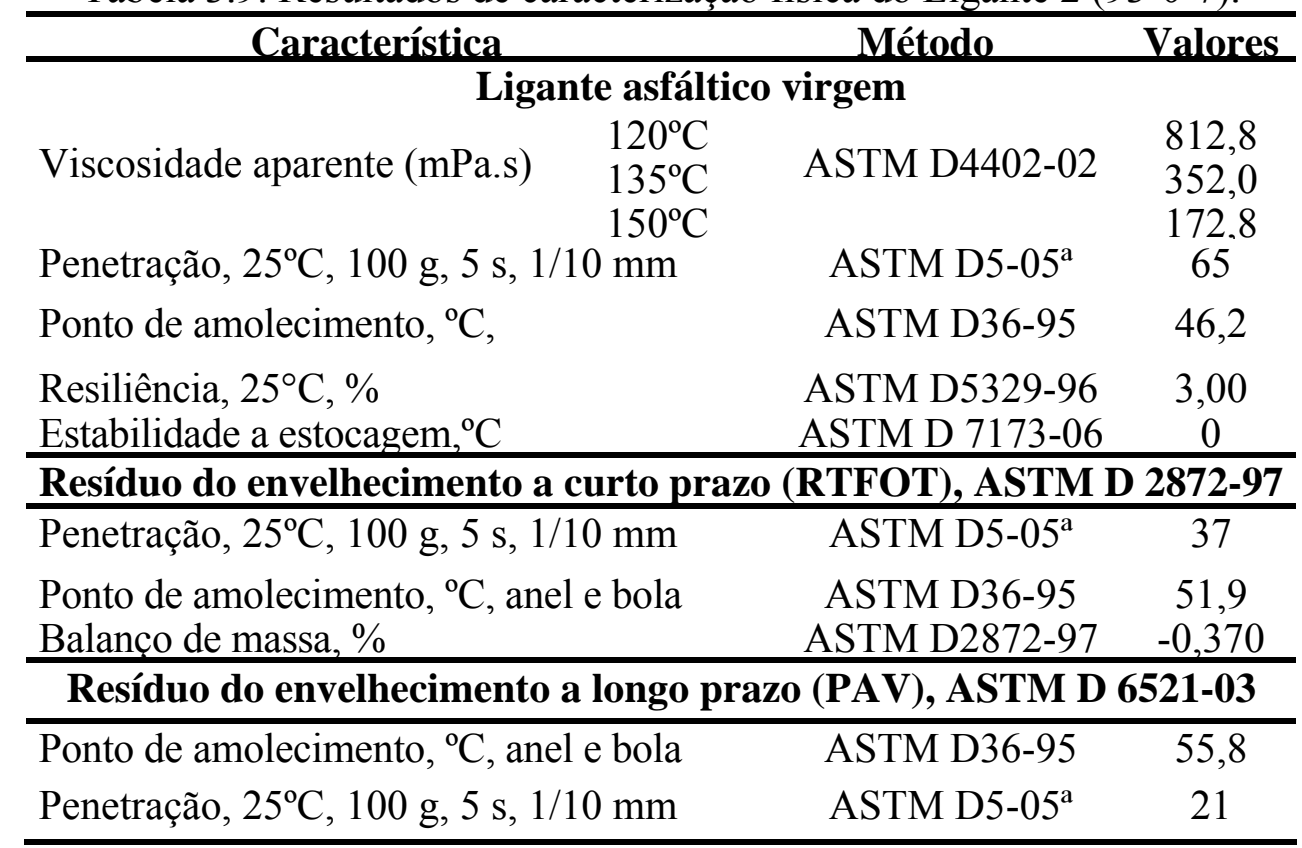

Tabela 3.10. Resultados de caracterização física do Ligante 3 (86-0-14)

\begin{tabular}{|c|c|c|c|}
\hline Característica & & Método & Valores \\
\hline Liga & te asfáltic & irgem & \\
\hline & $120^{\circ} \mathrm{C}$ & & 554,7 \\
\hline Viscosidade aparente (mPa.s) & $135^{\circ} \mathrm{C}$ & ASTM D4402-02 & 240,3 \\
\hline & $150^{\circ} \mathrm{C}$ & & 124,1 \\
\hline Penetração, $25^{\circ} \mathrm{C}, 100 \mathrm{~g}, 5 \mathrm{~s}, 1$ & $0 \mathrm{~mm}$ & ASTM D5-05a & 114 \\
\hline Ponto de amolecimento, ${ }^{\circ} \mathrm{C}$, an & e bola & ASTM D36-95 & 41,3 \\
\hline Resiliência, $25^{\circ} \mathrm{C}, \%$ & & ASTM D5329-96 & 0,75 \\
\hline Estabilidade a estocagem, ${ }^{\circ} \mathrm{C}$ & & ASTM D 7173-06 & 0 \\
\hline Resíduo do envelhecimento a & urto praz & RTFOT), ASTM D & $2872-97$ \\
\hline Penetração, $25^{\circ} \mathrm{C}, 100 \mathrm{~g}, 5 \mathrm{~s}, 1$ & $0 \mathrm{~mm}$ & ASTM D5-05a & 54 \\
\hline Ponto de amolecimento, ${ }^{\circ} \mathrm{C}$, an & e bola & ASTM D36-95 & 48,8 \\
\hline Balanco de massa, \% & & ASTM D2872-97 & $-0,831$ \\
\hline Resíduo do envelhecimen & a longo I & Zo (PAV),ASTM D & 6521-03 \\
\hline ponto de amolecimento, ${ }^{\circ}$ & , anel e & ASTM D36-95 & 52,1 \\
\hline penetração, $25^{\circ} \mathrm{C}, 100 \mathrm{~g}, 5 \mathrm{~s}$ & $1 / 10 \mathrm{~mm}$ & ASTM D5-05a & 26 \\
\hline
\end{tabular}


Tabela 3.11. Resultados de caracterização física do Ligante 4 (91-9-0).

\begin{tabular}{|c|c|c|c|}
\hline Característica & & Método & Valores \\
\hline \multicolumn{4}{|c|}{ Ligante asfáltico virgem } \\
\hline Viscosidade aparente (mPa.s) & $\begin{array}{l}120^{\circ} \mathrm{C} \\
135^{\circ} \mathrm{C}\end{array}$ & ASTM D4402-02 & - \\
\hline Penetração, $25^{\circ} \mathrm{C}, 100 \mathrm{~g}, 5 \mathrm{~s}, 1 /$ & $\mathrm{nm}$ & ASTM D5-05a & $\begin{array}{r}3839 \\
30\end{array}$ \\
\hline Ponto de amolecimento, ${ }^{\circ} \mathrm{C}$, & & ASTM D36-95 & 56,4 \\
\hline Resiliência, $25^{\circ} \mathrm{C}, \%$ & & AST & 21,00 \\
\hline Estabilidade a estocagem, ${ }^{\circ} \mathrm{C}$ & & ASTM D 7173-06 & 6,9 \\
\hline \multicolumn{4}{|c|}{ Resíduo do envelhecimento a curto prazo (RTFOT),ASTM D 2872-97 } \\
\hline Penetração, $25^{\circ} \mathrm{C}, 100 \mathrm{~g}, 5 \mathrm{~s}, 1 /$ & & ASTM D5-05a & 26 \\
\hline Ponto de amolecimento, ${ }^{\circ} \mathrm{C}$, & & ASTM D36-95 & 62,3 \\
\hline Balanço de massa, \% & & ASTM D2872-97 & $-0,177$ \\
\hline \multicolumn{4}{|c|}{ Resíduo do envelhecimento a longo prazo (PAV), ASTM D 6521-03 } \\
\hline Ponto de amolecimento, ${ }^{\circ} \mathrm{C}$, & & ASTM D36-95 & 67,4 \\
\hline Penetração, $25^{\circ} \mathrm{C}, 100 \mathrm{~g}, 5 \mathrm{~s}, 1 /$ & $\mathrm{nm}$ & ASTM D5-05a & 17 \\
\hline
\end{tabular}

Tabela 3.12. Resultados de caracterização física do Ligante 5 (77-9-14).

\begin{tabular}{|c|c|c|c|}
\hline Característica & & Método & Valores \\
\hline \multicolumn{4}{|c|}{$\begin{array}{c}\text { Ligante asfáltico virgem } \\
\end{array}$} \\
\hline Viscosidade aparente (mPa.s) & $\begin{array}{l}120^{\circ} \mathrm{C} \\
135^{\circ} \mathrm{C} \\
150^{\circ} \mathrm{C}\end{array}$ & ASTM D4402-02 & $\begin{array}{c}- \\
- \\
2423,5\end{array}$ \\
\hline Penetração, $25^{\circ} \mathrm{C}, 100 \mathrm{~g}, 5 \mathrm{~s}, 1 / 1$ & $\mathrm{~mm}$ & ASTM D5-05a & 94 \\
\hline Ponto de amolecimento, ${ }^{\circ} \mathrm{C}$ & & ASTM D36-95 & 46,2 \\
\hline Resiliência, $25^{\circ} \mathrm{C}, \%$ & & ASTM D5329-96 & 10,67 \\
\hline Estabilidade a estocagem, ${ }^{\circ} \mathrm{C}$ & & ASTM D 7173-06 & 8,3 \\
\hline \multicolumn{4}{|c|}{ Resíduo do envelhecimento a curto prazo (RTFOT),ASTM D 2872-97 } \\
\hline $\begin{array}{l}\text { Penetracão, } 25^{\circ} \mathrm{C}, 100 \mathrm{~g}, 5 \mathrm{~s}, 1 / 1 \\
\text { Ponto de amolecimento, }{ }^{\circ} \mathrm{C}, \\
\text { Balanço de massa, } \%\end{array}$ & & $\begin{array}{c}\text { ASTM D5-05a } \\
\text { ASTM D36-95 } \\
\text { ASTM D2872-97 } \\
\end{array}$ & $\begin{array}{c}48 \\
54,3 \\
-0,921 \\
\end{array}$ \\
\hline \multicolumn{4}{|c|}{ Resíduo do envelhecimento a longo prazo (PAV), ASTM D 6521-03 } \\
\hline $\begin{array}{l}\text { Ponto de amolecimento, }{ }^{\circ} \mathrm{C}, \\
\text { Penetração, } 25^{\circ} \mathrm{C}, 100 \mathrm{~g}, 5 \mathrm{~s}, 1 / 1\end{array}$ & & $\begin{array}{l}\text { ASTM D36-95 } \\
\text { ASTM D5-05a }\end{array}$ & $\begin{array}{c}59,7 \\
33\end{array}$ \\
\hline
\end{tabular}


Tabela 3.13. Resultados de caracterização física do Ligante 6 (82-18-0).

\begin{tabular}{|c|c|c|c|}
\hline Característica & & Método & Valores \\
\hline \multicolumn{4}{|c|}{ Ligante asfáltico virgem } \\
\hline Viscosidade aparente (mPa.s) & $\begin{array}{l}120^{\circ} \mathrm{C} \\
135^{\circ} \mathrm{C}\end{array}$ & ASTM D4402-02 & - \\
\hline Penetração, $25^{\circ} \mathrm{C}, 100 \mathrm{~g}, 5 \mathrm{~s}, 1$ & $\begin{array}{l}150^{\circ} \mathrm{C} \\
\mathrm{mm}\end{array}$ & ASTM D5- $05^{\mathrm{a}}$ & $\begin{array}{c}5191,1 \\
30\end{array}$ \\
\hline Ponto de amolecimento, ${ }^{\circ} \mathrm{C}$, & & ASTM D36-95 & 67,5 \\
\hline Resiliência, $25^{\circ} \mathrm{C}, \%$ & & ASTM D5329-96 & 46,67 \\
\hline Estabilidade a estocagem, ${ }^{\circ} \mathrm{C}$ & & ASTM D 7173-06 & 9,5 \\
\hline \multicolumn{4}{|c|}{ Resíduo do envelhecimento a curto prazo (RTFOT), ASTM D 2872-97 } \\
\hline Penetração, $25^{\circ} \mathrm{C}, 100 \mathrm{~g}, 5 \mathrm{~s}, 1$ & $\mathrm{~mm}$ & ASTM D5-05 & 24 \\
\hline Ponto de amolecimento, ${ }^{\circ} \mathrm{C}$, & & ASTM D36-95 & 70,3 \\
\hline Balanço de massa, \% & & ASTM D2872-97 & $-0,024$ \\
\hline \multicolumn{4}{|c|}{ Resíduo do envelhecimento a longo prazo (PAV), ASTM D 6521-03 } \\
\hline Ponto de amolecimento, ${ }^{\circ} \mathrm{C}$, & & ASTM D36-95 & 71,3 \\
\hline Penetração, $25^{\circ} \mathrm{C}, 100 \mathrm{~g}, 5 \mathrm{~s}, 1$ & $\mathrm{~mm}$ & ASTM D5-05 & 26 \\
\hline
\end{tabular}

Tabela 3.14. Resultados de caracterização física do Ligante 7 (75-18-7).

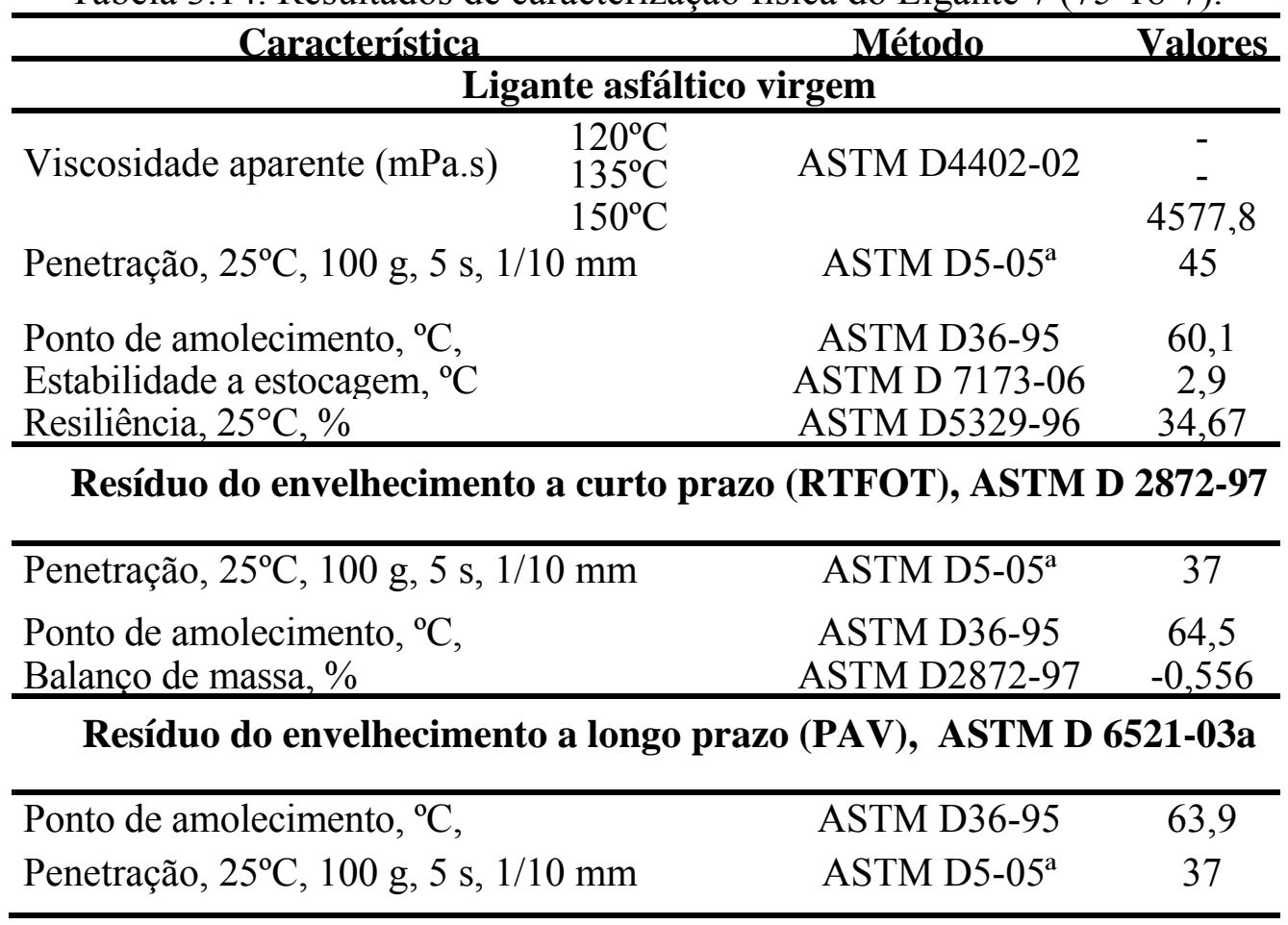


Tabela 3.15. Resultados de caracterização física do Ligante 8 (68-18-14).

\begin{tabular}{|c|c|c|c|}
\hline Característica & & Método & Valores \\
\hline \multicolumn{4}{|c|}{$\begin{array}{c}\text { Ligante asfáltico virgem } \\
\end{array}$} \\
\hline Viscosidade aparente (mPa.s) & $\begin{array}{l}120^{\circ} \mathrm{C} \\
135^{\circ} \mathrm{C} \\
150^{\circ} \mathrm{C}\end{array}$ & ASTM D4402-02 & $\begin{array}{c}- \\
- \\
3608,9\end{array}$ \\
\hline Penetração, $25^{\circ} \mathrm{C}, 100 \mathrm{~g}, 5 \mathrm{~s}, 1 /$ & $\mathrm{mm}$ & ASTM D5-05a & 70 \\
\hline $\begin{array}{l}\text { Ponto de amolecimento, }{ }^{\circ} \mathrm{C} \text {, } \\
\text { Estabilidade a estocagem, }{ }^{\circ} \mathrm{C}\end{array}$ & & $\begin{array}{c}\text { ASTM D36-95 } \\
\text { ASTM D 7173-06 } \\
\end{array}$ & $\begin{array}{c}56,3 \\
1,1 \\
\end{array}$ \\
\hline Resiliência. $25^{\circ} \mathrm{C} . \%$ & & ASTM D5329-96 & 25.00 \\
\hline \multicolumn{4}{|c|}{ Resíduo do envelhecimento a curto prazo (RTFOT), ASTM D 2872-97 } \\
\hline $\begin{array}{l}\text { Penetracão, } 25^{\circ} \mathrm{C}, 100 \text { g, } 5 \mathrm{~s}, 1 / \\
\text { Ponto de amolecimento, }{ }^{\circ} \mathrm{C}, \\
\text { Balanço de massa, } \%\end{array}$ & & $\begin{array}{c}\text { ASTM D5-05a } \\
\text { ASTM D36-95 } \\
\text { ASTM D2872-97 } \\
\end{array}$ & $\begin{array}{c}51 \\
55,3 \\
-1,387 \\
\end{array}$ \\
\hline \multicolumn{4}{|c|}{ Resíduo do envelhecimento a longo prazo (PAV), ASTM D 6521-03 } \\
\hline Ponto de amolecimento, ${ }^{\circ} \mathrm{C}$, & & ASTM D36-95 & 64,4 \\
\hline Penetração, $25^{\circ} \mathrm{C}, 100 \mathrm{~g}, 5 \mathrm{~s}, 1 /$ & $\mathrm{mm}$ & ASTM D5-05a & 48 \\
\hline
\end{tabular}

\subsection{Procedimentos e Equipamentos de Laboratório}

\subsubsection{Ligantes Asfálticos}

Para produção das misturas asfalto-borracha e asfalto-borracha-óleo, foi utilizado misturador de alto cisalhamento da marca Silverson, modelo L4RT, sob rotação de $4.000 \mathrm{rpm}$, na temperatura de $170^{\circ} \mathrm{C}$, durante $90 \mathrm{~min}$. Na preparação das misturas asfalto-óleo, utilizou-se misturador de baixo cisalhamento marca Fisatom, modelo 722D, sob rotação de $400 \mathrm{rpm}$, temperatura de $135^{\circ} \mathrm{C}$ e tempo de $20 \mathrm{~min}$. Uma manta aquecedora marca Fisatom, modelo 647 , foi empregada para o condicionamento térmico das misturas durante o processamento. A temperatura foi controlada por meio de um controlador de temperatura externo, ao qual foi conectado um sensor que permanecia imerso na mistura e fixado a uma haste de apoio. Foram preparadas bateladas de 3,0 1 .

A teoria sobre misturas indica que a ordem de adição dos componentes pode alterar a qualidade do produto final. Portanto, adotou-se a mesma seqüência de adição dos 
componentes, nas quantidades estabelecidas na Tabela 3.1. No caso das misturas asfaltoborracha-óleo, a adição dos materiais foi feita na seguinte ordem:

- Primeiramente, o ligante asfáltico de base era aquecido e a quantidade corresponde à mistura a ser preparada era colocada no recipiente de misturação (bequer);

- Em seguida, o resíduo de óleo de xisto era vertido no bequer na quantidade desejada;

- Posteriormente, o béquer era colocado na manta de aquecimento, a temperatura da manta e a rotação do misturador de alto cisalhamento eram ajustadas e só então a borracha, previamente pesada, era adicionada em pequenas quantidades. O tempo de processamento começava a ser cronometrado após a conclusão da adição da borracha e a estabilização da temperatura.

Para as misturas asfalto-borracha, o ligante asfáltico de base era aquecido, pesado e vertido no béquer e levado diretamente para o misturador de alto cisalhamento, sendo, então, ajustadas à temperatura da manta e a rotação do agitador. Depois de adicionada à borracha e estabilizada a temperatura, o tempo de processamento começava a ser cronometrado.

No caso das misturas asfalto-óleo, empregando misturador de baixo cisalhamento, o CAP era aquecido, pesado e vertido no béquer, sendo adicionada, na seqüência, a quantidade de óleo prevista. O béquer era, então, ajustado à manta e quando a temperatura de $135^{\circ} \mathrm{C}$ era alcançada, a rotação do agitador era fixada (400 rpm) e o tempo de processamento, de $20 \mathrm{~min}$, passava a ser cronometrado.

O envelhecimento das misturas a curto prazo foi efetuado por meio de estufas de filme fino rotativo (RTFOT), conforme método ASTM D 2872-97. Foram empregadas duas estufas, uma da marca Despatch, modelo RTFOT, e outra da marca James Cox e Sons, modelo CS 325-A. Paralelamente ao envelhecimento, foi realizado o ensaio de balanço de massa, segundo essa norma, empregando balança analítica com precisão de décimo de milésimo de grama. O envelhecimento a longo prazo do resíduo envelhecido no RTFOT, conforme especificação ASTM 6521-03a, foi efetuado em estufa de vaso pressurizado (PAV) da marca Prentex, modelo 9300.

A viscosidade aparente (ASTM 4402-02) foi medida em um viscosímetro Brookfield modelo DV III Ultra Programmable Rheometer, dotado de dispositivo Thermosel, empregando 
"spindles" 18, 21 e 34. O procedimento adotado foi descrito a seguir, que permitiu a obtenção de valores de viscosidade adequados para o propósito de modelagem:

- a viscosidade do CAP foi medida com "spindle" 21 e as das amostras asfalto-óleo foram medidas com "spindle" 18, sem substituição de amostras e com taxas de cisalhamento arbitrárias. Uma vez que esses são asfaltos newtonianos, o ensaio foi realizado nas temperaturas de 120,135 e $150^{\circ} \mathrm{C}$, com três determinações da viscosidade espaçadas de $1 \mathrm{~min}$;

- a viscosidade das amostras asfalto-borracha-óleo foi obtida com "spindle" 18 e das amostras asfalto-borracha foi medida com "spindle" 34, apenas na temperatura de $150^{\circ} \mathrm{C}$. A taxa de cisalhamento empregada foi de $6,8 \mathrm{~s}-$, com três determinações da viscosidade espaçadas de $1 \mathrm{~min}$.

Os ensaios de ponto de amolecimento (ASTM D36-95) foram realizados em dois equipamentos: um da marca ISL, modelo RB 36, e outro da marca Herzog, modelo HRB 754. Os ensaios de penetração (ASTM D5-97) e de resiliência (ASTM D 5329-96) foram executados em equipamento marca Humboldt, modelo H1240. O ensaio de resiliência emprega o mesmo equipamento do ensaio de penetração. Nesse caso, a agulha de penetração deve ser substituída pela haste de penetração, sendo o peso total da esfera mais a haste de penetração igual a $75 \pm 0,01 \mathrm{~g}$.

Como não se dispõe de um critério de especificação para a estabilidade à estocagem do asfalto-borracha, empregou-se o ensaio ASTM D 7173-06 ("Standard practice for determining the separation tendency of polymer from polymer modified asphalt") aplicado na avaliação da estabilidade à estocagem entre polímero e ligante asfáltico durante estocagem sob temperaturas de manuseio e transporte. A separação do polímero do ligante asfáltico, durante a estocagem sob temperaturas altas, é avaliada por meio da comparação de valores de ponto de amolecimento, medido em amostras do ligante asfáltico modificado, obtidas das partes superior e inferior de um tubo preenchido com amostra, após ser submetida ao condicionamento que simula a estocagem. O condicionamento consiste em colocar um tubo padronizado preenchido de ligante asfáltico modificado e lacrado na posição vertical em estufa na temperatura de $163 \pm 5{ }^{\circ} \mathrm{C}$ durante o período de $48 \pm 1 \mathrm{~h}$. 


\subsubsection{Misturas Asfálticas}

Nesta seção são apresentados os procedimentos experimentais e os materiais empregados no estudo do asfalto-borracha e das misturas modificadas. Do mesmo modo, são descritos a preparação dos corpos-de-prova; assim como os procedimentos para determinação das temperaturas de usinagem e de compactação das misturas. Posteriormente, é detalhada a determinação dos parâmetros volumétricos (densidade, volume de vazios, relação betumevazios e vazios do agregado mineral) e, para finalizar, os procedimentos de ensaio de propriedades mecânicas das misturas asfálticas.

\subsubsection{Temperaturas de usinagem e de compactação}

Para determinação das temperaturas de usinagem e de compactação foram utilizados dois processos diferentes. O primeiro deles usado para ligantes que não contêm borracha na composição e o segundo para ligantes que contêm borracha. Para os ligantes sem o componente borracha foi empregado o método tradicional utilizados para os ligantes asfálticos newtonianos. A viscosidade Brookfield foi monitorada em três temperaturas distintas, para cada ligante asfáltico, visando o levantamento da curva viscosidade versus temperatura. As Figuras 3.5, 3.6 e 3.7 representam as curvas traçadas para determinação das referidas temperaturas. As temperaturas de mistura dos materiais foram estimadas para uma viscosidade de 0,17 Pa.s e as temperaturas de compactação foram estimadas para uma viscosidade de 0,28 Pa.s.

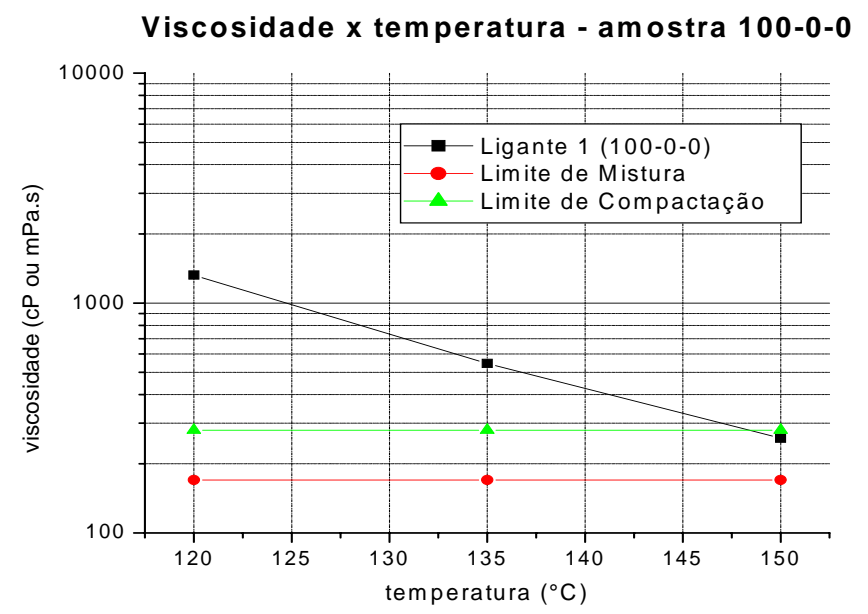

Figura 3.5. Viscosidade $\mathrm{x}$ temperatura para o ligante100-0-0 


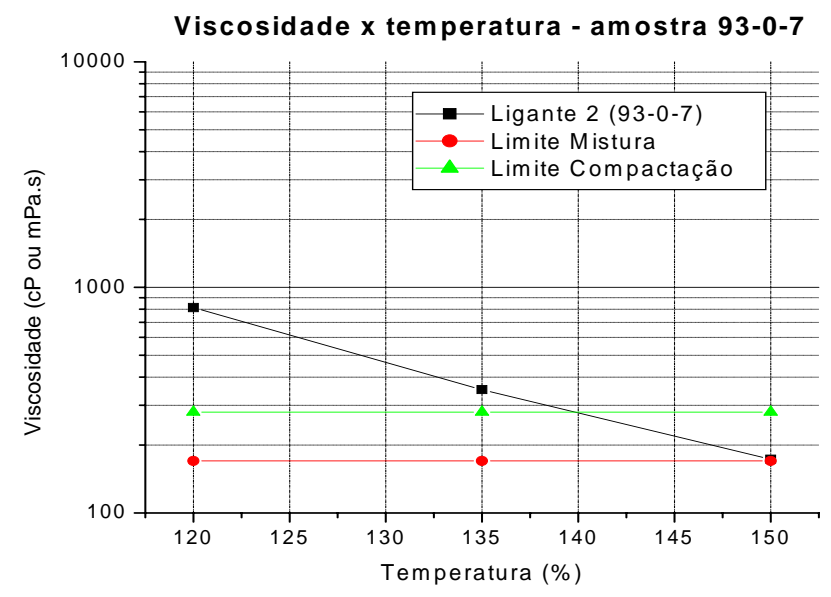

Figura 3.6. Viscosidade $\mathrm{x}$ temperatura para o ligante 93-0-7

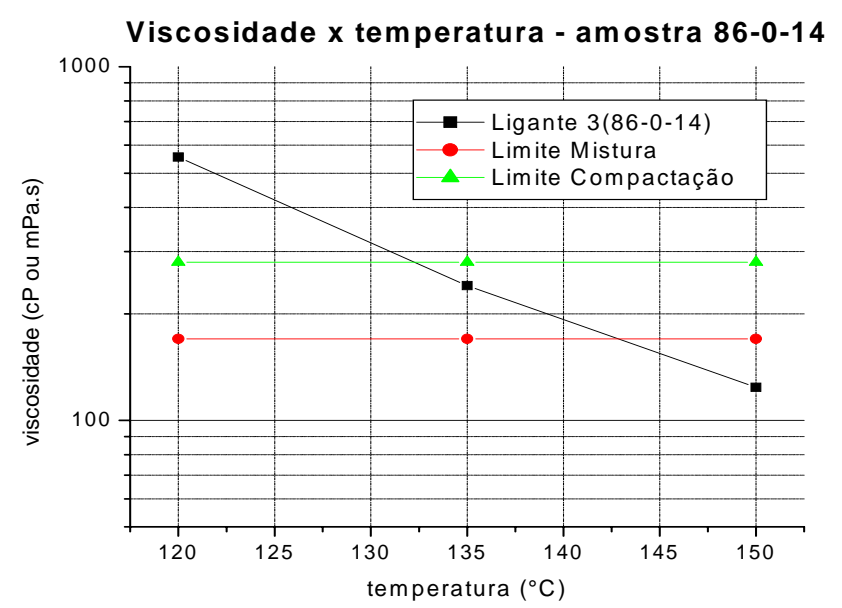

Figura 3.7. Viscosidade $\mathrm{x}$ temperatura para o ligante 86-0-14

Devido às dificuldades encontradas para monitorar a viscosidade aparente do ligante asfaltoborracha em ambas as temperaturas, optou-se por arbitrar as temperaturas de mistura e de compactação considerando a consistência destes ligantes e procurando não ultrapassar o limite de $180^{\circ} \mathrm{C}$. Na Tabela 3.16 estão às temperaturas de usinagem e de compactação. 
Tabela 3.16. Temperaturas de usinagem e de compactação.

\begin{tabular}{ccc}
\hline \multirow{2}{*}{ Misturas } & \multicolumn{2}{c}{ Temperaturas $\left({ }^{\circ} \mathbf{C}\right)$} \\
& Usinagem & Compactação \\
\hline $100-0-0$ & 158 & 148 \\
$91-9-0$ & 165 & 155 \\
$82-18-0$ & 180 & 170 \\
$93-0-7$ & 150 & 140 \\
$86-0-14$ & 143 & 132 \\
$75-18-7$ & 175 & 165 \\
$77-9-14$ & 155 & 145 \\
$68-18-14$ & 165 & 155 \\
\hline
\end{tabular}

\subsubsection{Determinação da Densidade Máxima Teórica de Misturas Asfálticas (Método Rice) - ASTM D 2041/00}

A densidade máxima teórica (DMM) é um parâmetro necessário para o cálculo da densidade efetiva do agregado, da absorção de asfalto pelo agregado, do teor de asfalto efetivo da mistura asfáltica e do volume de vazios ( Vv) numa dosagem de misturas asfálticas. A partir da densidade aparente dos agregados, da densidade aparente do corpo-de-prova compactado e da DMM determinam-se as características volumétricas de uma mistura asfáltica e, em vários métodos, sua dosagem quanto ao teor de ligante a ser empregado. São propriedades fundamentais cujos valores são influenciados pela composição da mistura em relação ao tipo e quantidade de materiais agregados e betuminosos.

O ensaio se resume em colocar uma amostra de mistura asfáltica, quantidade esta que depende do tamanho nominal máximo do agregado, em condição fofa em um recipiente que se conhece a tara. Em seguida, o recipiente é preenchido com água a $25^{\circ} \mathrm{C}$ até que toda a mistura fique coberta. É então aplicado gradualmente vácuo por um período de 15 minutos, a fim de expulsar os vazios existentes entre os filmes de ligante. Ao fim deste tempo, o vácuo é gradualmente solto. $\mathrm{O}$ volume da amostra da mistura asfáltica é obtido completando o nível do recipiente com água e pesando ao ar. Tanto a temperatura e a massa do conjunto são anotadas. A "DMM", ou Gmm, conforme descrito na referida norma, é determinada por: 


$$
D M M=\frac{A}{A-(C-B)}
$$

em que:

A: massa da amostra seca em ar (g),

B: massa do recipiente metálico imerso em água $(\mathrm{g})$,

$\mathrm{C}$ : massa do recipiente + amostra imerso em água $(\mathrm{g})$.

Através da DMM, do teor de asfalto $\left(\mathrm{P}_{\mathrm{b}}\right)$ e da densidade aparente dos agregados $\left(\rho_{\mathrm{ap}}\right)$, calculou-se a densidade efetiva do agregado $\left(\rho_{\mathrm{ef}}\right)$, cujo valor é usado no cálculo da absorção de asfalto $\left(\mathrm{Abs}_{\mathrm{asf}}\right)$. A densidade efetiva do agregado $\left(\rho_{\mathrm{ef}}\right)$ pode ser obtida através da expressão 3.9 .

$$
\rho_{e f}=\frac{1-P_{b}}{\frac{1}{D M M}+\frac{P_{b}}{\rho_{b}}}
$$

Então a absorção de asfalto pelo agregado pode ser determinada pela expressão 3.10:

$$
A B S_{a s f}=\frac{\rho_{e f}-\rho_{a p}}{\rho_{e f} * \rho_{a p}} * \rho_{b} * 100
$$

O ensaio foi realizado em misturas com os oito tipos de ligantes asfálticos, no teor de 5,5\%. Segundo os ensaios constatou-se que esse agregado apresenta valores não significativos quanto à absorção de ligante asfáltico e, portanto, ela não foi considerada nos cálculos, resultando na utilização de um único valor de $\rho_{\text {ef }}$ para cada mistura. A Tabela 3.17 apresenta os valores de $\rho_{\text {ef }}$ e de $\rho_{\text {asf }}$ dos ligantes asfálticos. 
Tabela 3.17. Densidades efetivas dos agregados e densidades dos ligantes asfálticos

\begin{tabular}{lll}
\hline Ligante asfáltico & $\rho_{\text {ef }}$ & $\rho_{\text {asf }}$ \\
\hline Ligante $1(100-0-0)$ & 2,869 & 1,004 \\
\hline Ligante $2(93-0-7)$ & 2,869 & 1,012 \\
\hline Ligante 3 (86-0-14) & 2,869 & 1,020 \\
\hline Ligante $4(91-9-0)$ & 2,867 & 1,026 \\
\hline Ligante 5 (77-9-14) & 2,867 & 1,038 \\
\hline Ligante 6 (82-18-0) & 2,869 & 1,041 \\
\hline Ligante 7 (75-18-7) & 2,867 & 1,048 \\
\hline Ligante 8 (68-18-14) & 2,869 & 1,051 \\
\hline
\end{tabular}

\subsubsection{Procedimento de moldagem dos corpos-de-prova}

O agregado mineral foi aquecido em uma misturadora de massa adaptada para esta finalidade (Figura 3.8) e, posteriormente, adicionou-se o ligante asfáltico para realizar a homogeneização do material. Em seguida, foram separadas porções de $1.200,00 \mathrm{~g}$ e armazenados em tigelas metálicas, que foram acondicionadas em estufa pelo período de $2 \mathrm{~h}$ na temperatura de compactação, visando simular o efeito do tempo médio de armazenamento na usina e transporte do material até a obra.

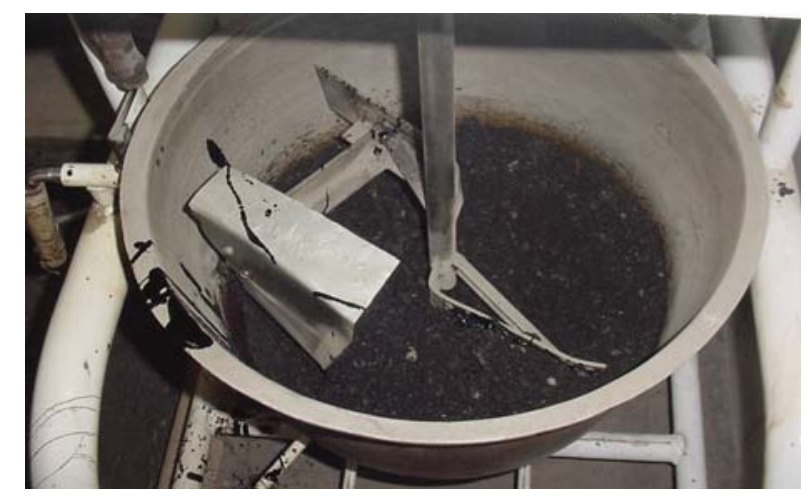

Figura 3.8. Equipamento adaptado para o procedimento de mistura

Foram empregados cinco teores de ligante asfáltico: 4,5; 5,0;5,5;6,0 e 6,5\%, sendo compactados sete corpos-de-prova para cada teor. Todas as misturas asfálticas foram compactadas nestes teores, por se tratar de um requisito do planejamento do experimento. Os corpos-de-prova foram compactados nas temperaturas de compactação indicadas na Tabela 3.16. O número de golpes depende do tráfego de projeto, sendo que neste estudo foi analisado 
o caso de tráfego pesado, representado por 75 golpes por face e o mais utilizado no Brasil, principalmente, em rodovias de médio a alto volume de tráfego. A desmoldagem dos corposde-prova foi efetuada após resfriamento até a temperatura ambiente, por um período de 2 horas aproximadamente.

\subsubsection{Parâmetros volumétricos}

Depois de confeccionados e desmoldados os corpos-de-prova, foram realizadas as medidas de diâmetro e altura e, posteriormente, eles foram submetidos à determinação de massas ao ar, sob imersão e sob saturação com superfície seca. Os parâmetros determinados mediante o ensaio Marshall foram: estabilidade (E), fluência $(F)$; densidade aparente $\left(D_{a p}\right)$, volume de vazios $\left(\mathrm{V}_{\mathrm{v}}\right)$, relação betume-vazios (RBV), e vazios do agregado mineral (VAM). Os cálculos das propriedades volumétricas foram feitos conforme o roteiro apresentado a seguir:

Densidade aparente:

$$
D_{a p}=\frac{\text { massaao ar }}{\text { massaao ar - massa imersa }}
$$

Volume de vazios: $V_{v}=\left(1-\frac{D_{a p}}{D M M}\right) \cdot 100$

Vazios do agregado mineral: $V A M=\left(1-\frac{D_{a p}(1-\% a s f)}{\rho_{a g}}\right) \cdot 100$

em que $\rho_{\mathrm{ag}}$ é a densidade da porção pétrea da mistura, obtida através da ponderação entre as densidades do agregado miúdo, obtida pelo método ASTM C128-93, e do agregado graúdo, obtida pelo método ASTM C127-91, conforme exposto no item 3.2.1.1.

Relação betume-vazios: $R B V=\frac{V A M-V_{v}}{V A M} \cdot 100$ 
Os resultados do ensaio Marshall proporcionam curvas de densidade, volume de vazios, relação betume-vazios, fluência e estabilidade em função dos teores de cimento asfáltico. Os cálculos e as curvas referentes a esses parâmetros estão no Apêndice A.

\subsubsection{Ensaios de propriedades mecânicas}

Durante a pesquisa foram moldados 280 corpos-de-prova, divididos em 8 misturas asfálticas, com 5 teores de ligante asfáltico por mistura e 7 réplicas por teor de ligante. A Tabela 3.18 apresenta a destinação dos corpos-de-prova para cada mistura.

Tabela 3.18. Quantidade de corpos-de-prova ensaiados por mistura estudada

Ensaios

\begin{tabular}{ccccc}
\cline { 2 - 5 } Teores & $\begin{array}{c}\text { Estabilidade e } \\
\text { Fluência }\end{array}$ & $\begin{array}{c}\text { Resistência } \\
\text { à Tração }\end{array}$ & $\begin{array}{c}\text { Umidade } \\
\text { Induzida }\end{array}$ & $\begin{array}{c}\text { Módulo de } \\
\text { Resiliência* }\end{array}$ \\
\hline $4,5 \%$ & 2 & 2 & 3 & 7 \\
\hline $5,0 \%$ & 2 & 2 & 3 & 7 \\
\hline $5,5 \%$ & 2 & 2 & 3 & 7 \\
\hline $6,0 \%$ & 2 & 2 & 3 & 7 \\
\hline $6,5 \%$ & 2 & 2 & 3 & 7 \\
\hline Total de corpo-de-prova & & & 35
\end{tabular}

*O ensaio de Módulo de Resiliência e das propriedades volumétricas foram realizados em todos os corpos de prova.

\subsubsection{Módulo de Resiliência}

Este ensaio foi realizado segundo o procedimento da norma DNER-ME 133/94. A temperatura empregada foi a de $25^{\circ} \mathrm{C}$. O equipamento utilizado nesse ensaio está ilustrado na Figura 3.9 apresentada a seguir. Trata-se de uma prensa dotada de sistema pneumático de aplicação de carga, feita por um pistão, acionado por um programa computacional, também responsável pelo registro das leituras de carga e deslocamento, obtidos por uma célula de carga e um conjunto de LVDTs. 


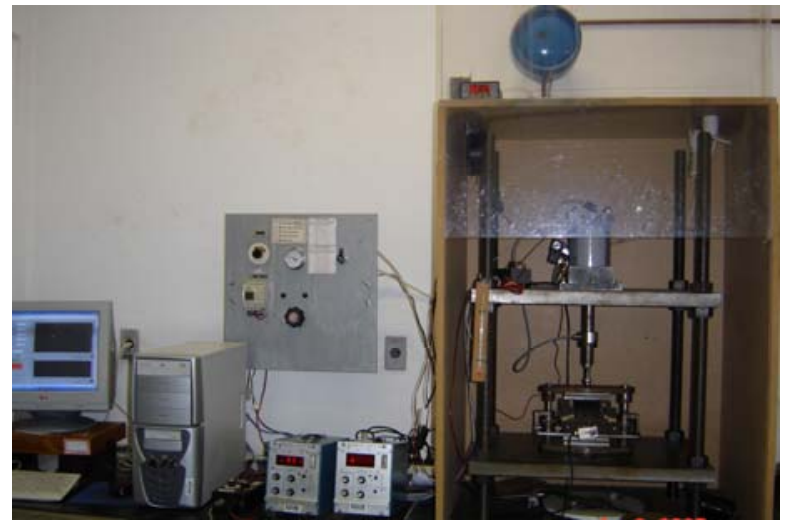

Figura 3.9. Equipamento utilizado para ensaio de módulo de resiliência

Para realização do ensaio, o corpo-de-prova foi posicionado em um suporte; em seguida foi fixado o medidor de deslocamento do tipo LVDT. O conjunto foi levado à prensa, faz-se com que o LVDT ficasse centralizado em relação à altura do corpo-de-prova com a finalidade de medir o deslocamento médio, conforme demonstrado na Figura 3.10.

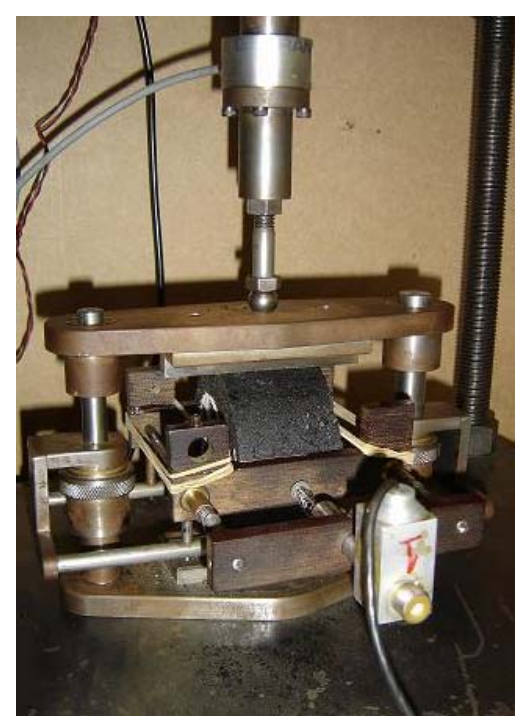

Figura 3.10. Montagem do corpo-de-prova no suporte

O procedimento de ensaio consistiu em aplicar 100 ciclos de carregamento de magnitude fixa, com duração de $1,0 \mathrm{~s}$, sendo $0,1 \mathrm{~s}$ de aplicação de carga e $0,9 \mathrm{~s}$ de recuperação. Como os ensaios de resistência à tração foram realizados posteriormente aos ensaios de módulo de resiliência, optou-se pelo controle do deslocamento vertical da amostra e não pelo controle da tensão aplicada (uma fração da sua resistência à tração). Assim, a carga foi ajustada de forma a obter deslocamentos da ordem de 0,0020 a 0,0030 mm. 
Para o cálculo do módulo de resiliência foram utilizados aproximadamente 30 a 40 ciclos de carregamento, com o objetivo de reduzir o desvio padrão a valores inferiores a $5 \%$ para misturas convencionais e $10 \%$ para misturas modificadas.

\subsubsection{Estabilidade e Fluência Marshall}

Segundo a norma DNER-ME 043/95, a estabilidade é a resistência máxima à compressão radial apresentada pelo corpo-de-prova, em N (Kgf), enquanto a fluência é a deformação total apresentada pelo corpo-de-prova, desde a aplicação da carga inicial nula até a aplicação da carga máxima, expressa em décimos de milímetros.

No presente trabalho, o ensaio foi realizado através da norma DNER-ME 043/95, que consiste em colocar os corpos-de-prova submersos em água a $60^{\circ} \mathrm{C}$, num período de 30 a 40 minutos. Em seguida, o CP é colocado no molde de compressão, levado até a prensa e submetido à compressão, até que se dê a ruptura, medindo-se nesse instante a carga máxima que a produziu (estabilidade). Tanto a adição da carga quanto a leitura da carga máxima e a fluência que, nesse trabalho, foram registrados por um programa computacional.

\subsubsection{Resistência à tração}

O ensaio de resistência à tração foi realizado conforme a norma DNER ME-138/94, descrito no item 2.5.1. O ensaio foi realizado na mesma prensa utilizada para os ensaios de estabilidade e fluência, conforme mostra a Figura 3.11, porém com alteração nos dispositivos de aplicação de carga, e na temperatura de $25^{\circ} \mathrm{C}$. 


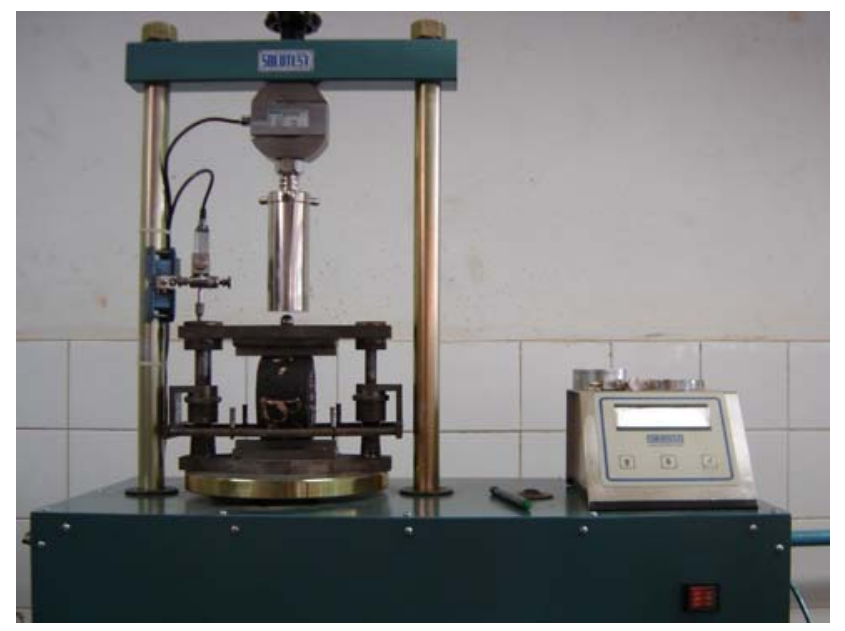

Figura 3.11. Prensa utilizada nos ensaios de estabilidade Marshall e resistência à tração

\subsubsection{Dano por umidade induzida}

A avaliação dos danos por umidade induzida foi feita a partir da relação entre a resistência à tração média de 3 corpos de prova submetidos previamente a condicionamentos e a resistência à tração média de 2 corpos de prova sem condicionamento. $\mathrm{O}$ valor desta relação pode ser utilizado para prever o desempenho de misturas asfálticas com relação à adesividade ligante/agregado e avaliar o benefício da adição de melhoradores de adesividade à mistura. A relação entre a resistência à tração dos corpos-de-prova submetidos ao condicionamento e não condicionados é chamada de Resistência à Tração Retida ou Razão de Resistência à Tração por compressão diametral (RRT).

Esse ensaio foi realizado segundo a norma ASTM D 4867, conforme exposto no item 2.5.3. Para a sua realização foram utilizados 3 corpos-de-prova por teor, para cada condição de condicionamento e para cada mistura estudada, totalizando em 120 corpos-de-prova. Depois de realizado o condicionamento dos corpos-de-prova, eles foram submetidos aos ensaios de módulo de resiliência e resistência à tração.

O condicionamento não foi possível de ser realizado em todos os corpos-de-prova selecionados, sendo que 44 corpos-de-prova permaneceram sem condicionamento. Os corposde-prova com teores de 4,5 e 5,0\% apresentaram mais facilidade para serem condicionados, porém para a maioria dos corpos-de-prova com $5,5,6,0,6,5 \%$ o condicionamento não foi possível. A dificuldade em se obter a saturação especificada por norma pode estar relacionada 
aos altos teores de asfalto e, conseqüentemente, a baixos volume de vazios, ou pela baixa conectividade entre os vazios. Outro fator a ser considerado é a textura superficial dos corposde-prova que, em alguns casos, se apresenta bem compacta e lisa, conforme mostram a Figura 3.12 e a Figura 3.13, o que pode ter dificultado a entrada de água.

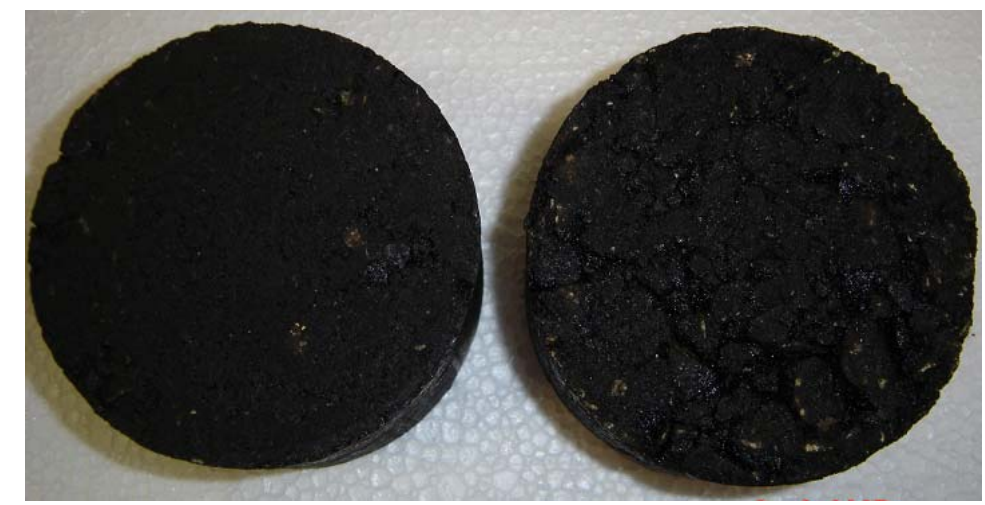

(a)

(b)

Figura 3.12. Textura superficial do topo do corpo-de-prova (a)não condicionado e

(b)condicionado.

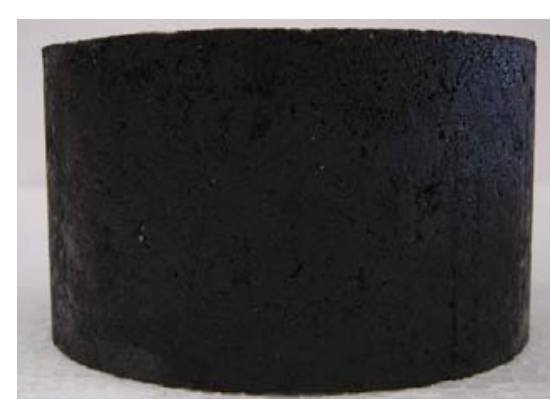

(a)

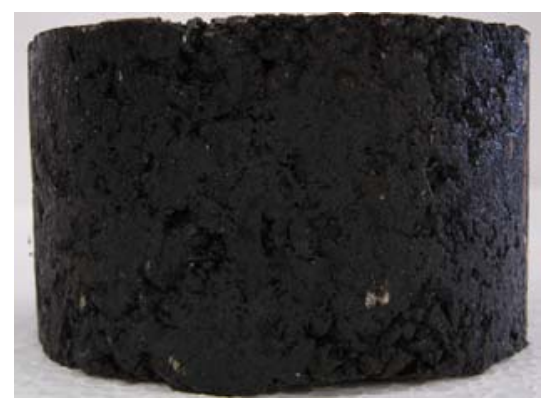

(b)

Figura 3.13. Textura superficial do corpo-de-prova (a)não condicionado e (b)condicionado.

Devido a não saturação dos corpos-de-prova com teores de 5,5, 6,0 e 6,5\%, as propriedades referentes às amostras condicionadas não puderam ser analisadas, porém foram avaliadas para os teores de 4,5 e $5,0 \%$. 


\section{Capítulo 4}

\section{APRESENTAÇÃO E ANÁLISE DOS RESULTADOS}

Neste capítulo, são apresentados os resultados obtidos nos ensaios realizados para avaliar comparativamente o comportamento e o desempenho de misturas asfálticas elaboradas com asfalto convencional (misturas de referência) e com asfaltos com a incorporação de borracha de pneus (processo úmido) e do resíduo de óleo de xisto.

A organização do capítulo se deu em função das diversas variáveis de resposta investigadas: propriedades volumétricas das misturas, estabilidade e fluência, módulo de resiliência, resistência à tração e efeito deletério da água.

\subsection{Parâmetros Marshall}

\subsubsection{Volume de Vazios}

O volume de vazios ( $\mathrm{Vv}$ ) é o volume de ar existente entre as partículas do agregado envoltas pelo filme de asfalto, expresso como uma porcentagem do volume total da mistura compactada. A Tabela 4.1 apresenta os valores referentes ao volume de vazios para as oito misturas estudadas em função do teor de asfalto de moldagem.

Tabela 4.1 Volume de Vazios

\begin{tabular}{l|ccccc}
\multirow{2}{*}{ Ligantes } & \multicolumn{5}{|c}{ Teor de ligante asfáltico (\%) } \\
\cline { 2 - 6 } & $\mathbf{4 , 5}$ & $\mathbf{5 , 0}$ & $\mathbf{5 , 5}$ & $\mathbf{6 , 0}$ & $\mathbf{6 , 5}$ \\
\hline $\mathbf{1 0 0 - 0 - 0}$ & 7,9 & 6,3 & 4,2 & 2,7 & 1,0 \\
$\mathbf{9 3 - 0 - 7}$ & 6,1 & 4,7 & 3,4 & 1,9 & 1,1 \\
$\mathbf{8 6 - 0 - 1 4}$ & 9,0 & 6,3 & 3,3 & 2,1 & 0,9 \\
$\mathbf{9 1 - 9 - 0}$ & 9,0 & 6,4 & 5,7 & 2,6 & 3,5 \\
$\mathbf{8 2 - 1 8 - 0}$ & 7,9 & 6,7 & 4,5 & 3,0 & 2,9 \\
$\mathbf{7 7 - 9 - 1 4}$ & 7,0 & 5,2 & 4,2 & 2,4 & 2,2 \\
$\mathbf{7 5 - 1 8 - 7}$ & 7,2 & 5,1 & 4,7 & 2,9 & 2,8 \\
$\mathbf{6 8 - 1 8 - 1 4}$ & 10,4 & 9,2 & 7,3 & 6,3 & 5,0 \\
\hline
\end{tabular}


Conforme mostra a Tabela 4.1, o efeito do resíduo de óleo e da borracha são opostos, pois o óleo proporciona redução nos valores do $\mathrm{Vv}$ enquanto a borracha aumenta esse parâmetro. Observa-se que na mistura com adição de $7 \%$ de óleo ocorre uma redução no Vv, com exceção no teor de 6,5\%. Nota-se o mesmo comportamento para a mistura com adição de $14 \%$ de óleo, com exceção do teor de $4,5 \%$.

A adição de borracha na mistura apresenta um aumento no valor do $\mathrm{Vv}$, exceto na mistura com adição de $9 \%$ do componente no teor de 6,0\%. A mistura com adição de valores altos de óleo e intermediários de borracha (77-9-14) apresenta menores valores de Vv em relação à mistura de referência. Para a mistura com valores intermediários de óleo e altos de borracha (75-18-7) observa-se um aumento no parâmetro, exceto nos teores de 4,5\% e 5,0\%. A mistura com adição alta dos modificadores (68-18-14) apresenta um aumento no volume de vazios. Da mesma maneira, pode-se constatar como já esperado, a redução do volume de vazios com o aumento do teor de ligante asfáltico na mistura.

\subsubsection{Vazios do Agregado Mineral}

Vazios do agregado mineral (VAM) é a soma do volume de vazios (Vv) e do volume de asfalto efetivo, ou seja, volume de asfalto efetivo. Os valores obtidos nas misturas estudadas referentes ao VAM estão apresentados na Tabela 4.2.

Tabela 4.2 Vazios do agregado mineral

\begin{tabular}{c|ccccc}
\hline \multirow{2}{*}{ Ligantes } & \multicolumn{5}{|c}{ Teor de ligante asfáltico (\%) } \\
\cline { 2 - 6 } & $\mathbf{4 , 5}$ & $\mathbf{5 , 0}$ & $\mathbf{5 , 5}$ & $\mathbf{6 , 0}$ & $\mathbf{6 , 5}$ \\
\hline $\mathbf{1 0 0 - 0 - 0}$ & 18,9 & 18,5 & 17,8 & 17,7 & 17,4 \\
$\mathbf{9 3 - 0 - 7}$ & 17,2 & 17,0 & 17,0 & 16,9 & 17,3 \\
$\mathbf{8 6 - 0 - 1 4}$ & 19,6 & 18,4 & 16,9 & 16,5 & 17,0 \\
$\mathbf{9 1 - 9 - 0}$ & 19,7 & 18,4 & 19,0 & 17,4 & 19,2 \\
$\mathbf{8 2 - 1 8 - 0}$ & 19,3 & 18,5 & 17,7 & 17,5 & 18,5 \\
$\mathbf{7 7 - 9 - 1 4}$ & 17,8 & 17,2 & 17,5 & 17,1 & 18,0 \\
$\mathbf{7 5 - 1 8 - 7}$ & 17,9 & 17,1 & 17,8 & 17,4 & 18,4 \\
$\mathbf{6 8 - 1 8 - 1 4}$ & 20,6 & 20,6 & 20,0 & 20,2 & 20,1 \\
\hline
\end{tabular}

Quanto aos vazios do agregado mineral, observa-se na Tabela 4.2 que, tanto a adição de óleo quanto da borracha na mistura, proporcionam a diminuição do VAM, com exceção da adição 
de borracha nos teores de 4,5\% e 6,5\% de ligante. As misturas com a adição de concentrações altas dos dois modificadores (18\% e 14\%) apresentaram maiores valores de VAM. Pode-se imaginar que com teores mais elevados de asfalto, a espessura da película de asfalto que envolve as partículas também é mais espessa, o que pode contribuir para o acúmulo de borracha/óleo em torno das partículas do agregado promovendo o afastamento gradativo entre elas em função dos teores de borracha/óleo adicionados, fazendo com que o valor do VAM aumente.

\subsubsection{Relação Betume-vazios}

A relação betume-vazios representa o grau de preenchimento do VAM por asfalto. A Tabela 4.3 apresenta os valores de RBV encontrados na pesquisa.

Tabela 4.3 Relação Betume-vazios (\%)

\begin{tabular}{l|ccccc}
\hline \multirow{2}{*}{ Ligantes } & \multicolumn{5}{|c}{ Teor de ligante asfáltico (\%) } \\
\cline { 2 - 6 } & $\mathbf{4 , 5}$ & $\mathbf{5 , 0}$ & $\mathbf{5 , 5}$ & $\mathbf{6 , 0}$ & $\mathbf{6 , 5}$ \\
\hline $\mathbf{1 0 0 - 0 - 0}$ & 57,9 & 66,2 & 76,6 & 85,0 & 94,5 \\
$\mathbf{9 3 - 0 - 7}$ & 64,5 & 72,6 & 80,3 & 88,8 & 93,9 \\
$\mathbf{8 6 - 0 - 1 4}$ & 54,3 & 65,6 & 76,9 & 87,4 & 95,4 \\
$\mathbf{9 1 - 9 - 0}$ & 54,2 & 65,6 & 69,8 & 85,2 & 82,0 \\
$\mathbf{8 2 - 1 8 - 0}$ & 57,3 & 63,9 & 74,9 & 83,0 & 84,4 \\
$\mathbf{7 7 - 9 - 1 4}$ & 60,6 & 70,1 & 76,0 & 86,0 & 87,7 \\
$\mathbf{7 5 - 1 8 - 7}$ & 59,5 & 70,0 & 73,8 & 83,5 & 85,0 \\
$\mathbf{6 8 - 1 8 - 1 4}$ & 49,6 & 55,3 & 63,6 & 68,7 & 75,3 \\
\hline
\end{tabular}

Da tabela apresentada anteriormente nota-se que na mistura com adição de 7\% de óleo ocorre um aumento na RBV, com exceção no teor de $6,5 \%$. Nota-se o mesmo comportamento para a mistura com adição de $14 \%$ de óleo, com exceção dos teores de 4,5\%e 5,0\%.

A adição de borracha na mistura reduz o valor do parâmetro, exceto na mistura com adição de $9 \%$ do componente para o teor de 6,0\% de ligante. A mistura com adição de valores altos de óleo e intermediários de borracha (77-9-14) apresenta maiores valores de RBV em relação à mistura de referência, com exceção dos teores de 5,5 e 6,5\%. Para a mistura com valores intermediário de óleo e alto de borracha (75-18-7) observa-se uma redução no parâmetro, 
exceto nos teores de 4,5\% e 5,0\%. A mistura com adição alta dos modificadores (68-18-14) apresentam os menores valores de RBV. Pode-se observar também o aumento do parâmetro com o aumento do teor de ligante asfáltico. Nota-se que o efeito do resíduo de óleo de xisto e da borracha são antagônicos, pois o óleo proporciona um aumento nos valores do RBV enquanto a borracha diminui esse parâmetro.

\subsubsection{Densidade Aparente}

A Tabela 4.4 apresenta os resultados referentes à densidade aparente das misturas estudadas.

\begin{tabular}{c|ccccc}
\multirow{2}{*}{ Ligantes } & \multicolumn{5}{c}{ Teor de ligante asfáltico (\%) } \\
\cline { 2 - 6 } & $\mathbf{4 , 5}$ & $\mathbf{5 , 0}$ & $\mathbf{5 , 5}$ & $\mathbf{6 , 0}$ & $\mathbf{6 , 5}$ \\
\hline $\mathbf{1 0 0 - 0 - 0}$ & 2,437 & 2,461 & 2,494 & 2,513 & 2,535 \\
$\mathbf{9 3 - 0 - 7}$ & 2,489 & 2,505 & 2,518 & 2,535 & 2,536 \\
$\mathbf{8 6 - 0 - 1 4}$ & 2,415 & 2,464 & 2,523 & 2,548 & 2,547 \\
$\mathbf{9 1 - 9 - 0}$ & 2,414 & 2,463 & 2,460 & 2,521 & 2,478 \\
$\mathbf{8 2 - 1 8 - 0}$ & 2,423 & 2,460 & 2,499 & 2,518 & 2,500 \\
$\mathbf{7 7 - 9 - 1 4}$ & 2,471 & 2,499 & 2,504 & 2,531 & 2,516 \\
$\mathbf{7 5 - 1 8 - 7}$ & 2,467 & 2,502 & 2,494 & 2,522 & 2,505 \\
$\mathbf{6 8 - 1 8 - 1 4}$ & 2,385 & 2,397 & 2,429 & 2,434 & 2,450 \\
\hline
\end{tabular}

Observa-se da Tabela 4.4 que a adição de óleo proporciona o aumento da densidade das misturas em relação à mistura de referência. Exceção a esse efeito ocorre apenas na adição de teor alto de óleo (14\%) na mistura com teor de 4,5\%, onde há redução da densidade em 1\%, aproximadamente. Com a adição de borracha a densidade aparente aumentou, com exceção dos teores de $4,5 \%$ e $6,5 \%$, para as duas quantidades adicionadas.

Já na adição de valores intermediários de óleo e de borracha tem-se um aumento na densidade aparente; talvez esse fato possa ser explicado porque ao adicionar quantidades intermediárias desses dois componentes (teores baixos) as partículas de borracha envoltas em óleo e em asfalto preencheriam os espaços entre as partículas maiores dos agregados tornando a mistura mais densa. No entanto, quando são adicionadas grandes quantidades dos modificadores, eles acabam não só preenchendo os espaços entre as partículas como passam a provocar um 
afastamento entre elas devido a um provável acúmulo de material, e dessa maneira deixando a mistura menos densa, ou seja, diminuindo a densidade aparente e, como visto anteriormente, aumentando o VAM. Os demais dados referentes aos parâmetros volumétricos estão apresentados no Apêndice A.

\subsubsection{Estabilidade e Fluência}

A estabilidade é a resistência máxima apresentada pelo corpo-de-prova; os valores referentes a essa propriedade estão representados nas figuras apresentadas a seguir. Para melhor entendimento, optou-se por mostrar os resultados em três grupos, com misturas somente com adição de óleo, misturas somente com adição de borracha e misturas com adição dos dois modificadores. A Figura 4.1 mostra a estabilidade para as misturas com adição apenas de óleo (a) e apenas de borracha (b). Os dados detalhados estão apresentados no Apêndice B.

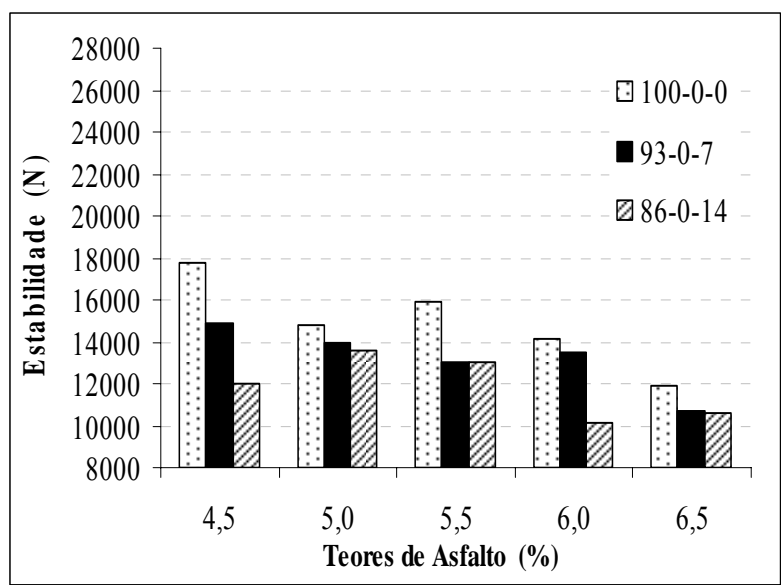

(a)

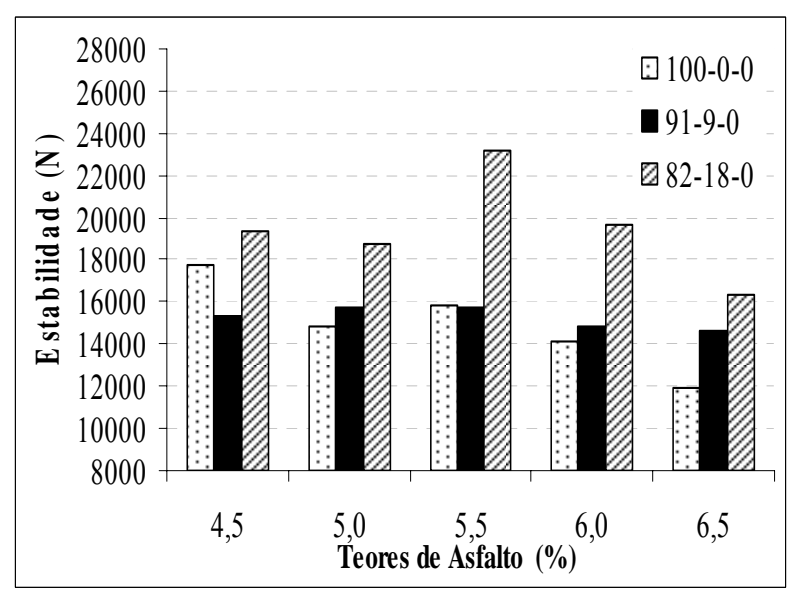

(b)

Figura 4.1: Estabilidade das misturas asfálticas: (a) adição de óleo e (b) adição de borracha

Através da Figura 4.1 (a) pode-se observar que a adição do óleo proporciona uma diminuição no valor da estabilidade em relação à mistura de referência. $\mathrm{O}$ mesmo se observa ao aumentar o teor de óleo de 7\% para 14\%. A maior redução ocorre na mistura $86-0-14$ no teor de 4,5\% onde o valor da estabilidade é reduzido em $32 \%$. No entanto, não é possível notar uma tendência definida ao se aumentar o teor de ligante asfáltico na mistura. 
As misturas com adição de borracha apresentam comportamento oposto daquelas com adição de óleo, como mostra a Figura 4.1 (b). A borracha proporciona um aumento da estabilidade das misturas em relação à de referência. Apenas a mistura com adição de $9 \%$ de borracha nos teores de $4,5 \%$ e $5,5 \%$, não apresentaram esse comportamento.

Da mesma maneira, pode-se observar que o aumento da adição de borracha, de $9 \%$ para 18\%, também provoca um aumento no valor da estabilidade, sendo que, o maior aumento, de $46 \%$, foi encontrado para a mistura com adição de $18 \%$ de borracha no teor de ligante asfáltico de 5,5\%. Para as misturas com adição de $9 \%$ de borracha, o aumento do teor de ligante asfáltico propicia maiores valores de estabilidade para teores até 5,5\% e uma diminuição para teores de $6,0 \%$ e 6,5\%. A mistura de referência, assim como as com adição de $18 \%$ de borracha, não apresenta uma tendência definida com o aumento do teor de ligantes asfáltico.

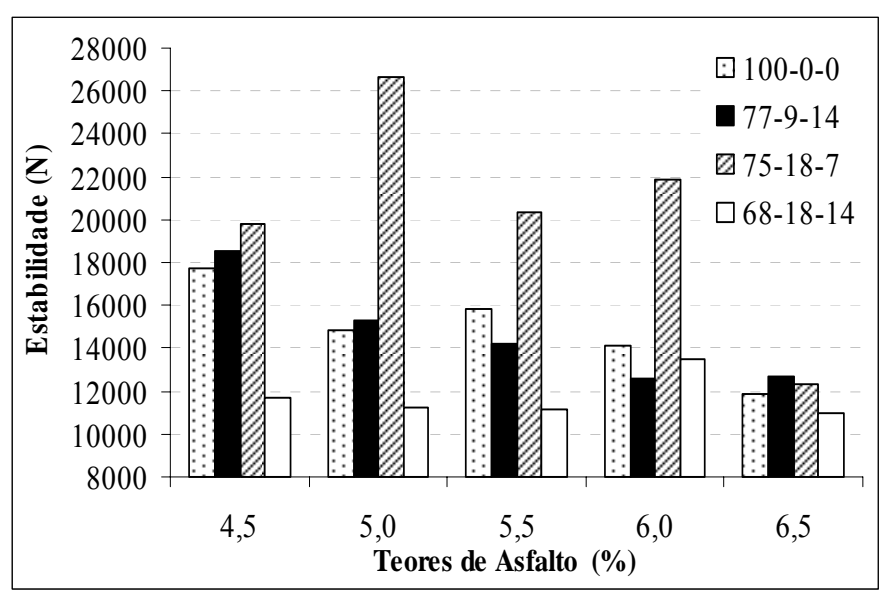

Figura 4.2: Estabilidade das misturas asfálticas com adição de óleo e borracha.

Da Figura 4.2 nota-se que a mistura com adição de 9\% de borracha e 14\% de óleo proporcionaram um aumento no valor da estabilidade, com exceção dos teores de ligante asfáltico de 5,5\% e 6,0\% que diminuíram a estabilidade em $16 \%$ e $0,8 \%$ respectivamente. A mistura com adição de $18 \%$ de borracha e $7 \%$ de óleo apresentou aumento dos valores de estabilidade, entretanto, a mistura com $18 \%$ de borracha e $14 \%$ de óleo (teores altos) proporcionou a diminuição da estabilidade. $\mathrm{O}$ aumento do teor de ligante asfáltico na mistura 77-9-14 aponta uma diminuição da propriedade analisada, com exceção do teor de 6,5\%. 
Em resumo, pode-se destacar que o óleo provoca uma diminuição da estabilidade das misturas, enquanto a borracha produz um efeito contrário, proporcionando o seu aumento.

A deformação total dos corpos-de-prova quando da ruptura no ensaio Marshall é representada através da fluência, cujos valores estão apresentados nos gráficos abaixo. A Figura 4.3 indica os valores de fluência das misturas com adição somente de óleo e borracha.

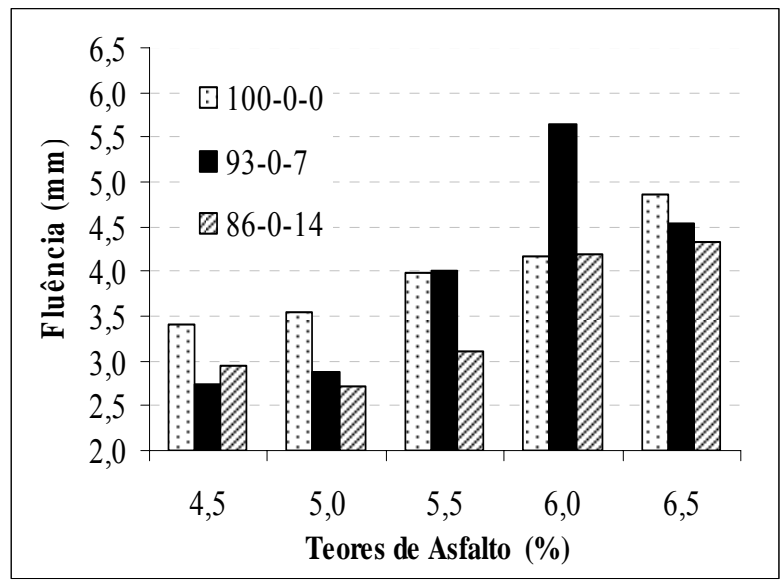

(a)

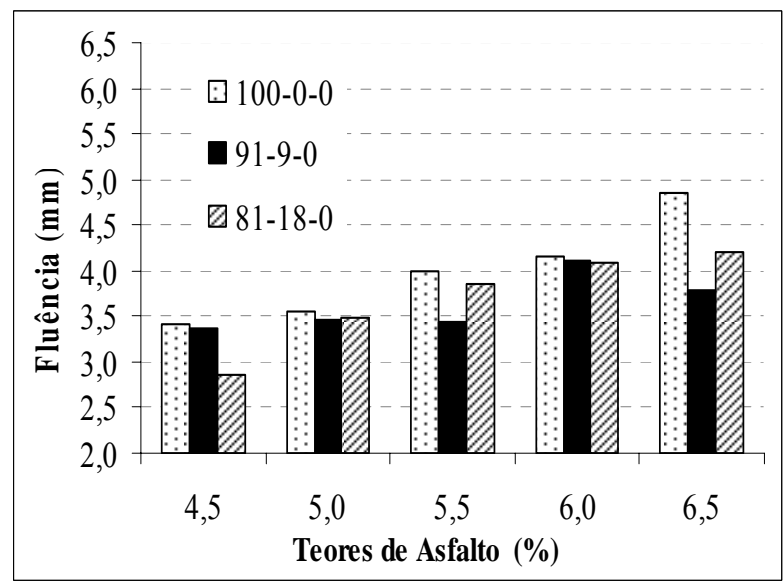

(b)

Figura 4.3: Fluência das misturas asfálticas: (a) adição de óleo e (b) adição de borracha

Pode-se observar na Figura 4.3 (a) que as misturas com adição de óleo apresentaram menores valores de fluência do que a mistura de referência, com exceção, apenas, para o teor de ligante asfáltico de 6,0\%, que apresenta valores superiores. Com a adição de 7\% de óleo observa-se uma redução da fluência, com diminuição de $20 \%$ na mistura com teor de 4,5\%. Já a mistura com adição de 14\% de óleo apresentou os menores valores de fluência, proporcionando redução de até $23 \%$, para o teor de ligante asfáltico de 5,0\%. Para as misturas não modificadas, o aumento do teor de ligante causou um aumento na fluência, contudo as misturas com adição somente de óleo não apresentaram um comportamento definido.

A adição de borracha na mistura asfáltica, conforme mostra a Figura 4.3 (b), reduz a fluência das misturas asfálticas. A mistura com adição de $9 \%$ de borracha, com exceção do teor de $4,5 \%$, proporcionou maior redução da fluência do que a adição de $18 \%$, em relação à mistura de referência. De maneira geral, o aumento do teor de ligante asfáltico propicia o aumento do valor da fluência, tanto para a mistura não modificada quanto para as com adição de borracha. 


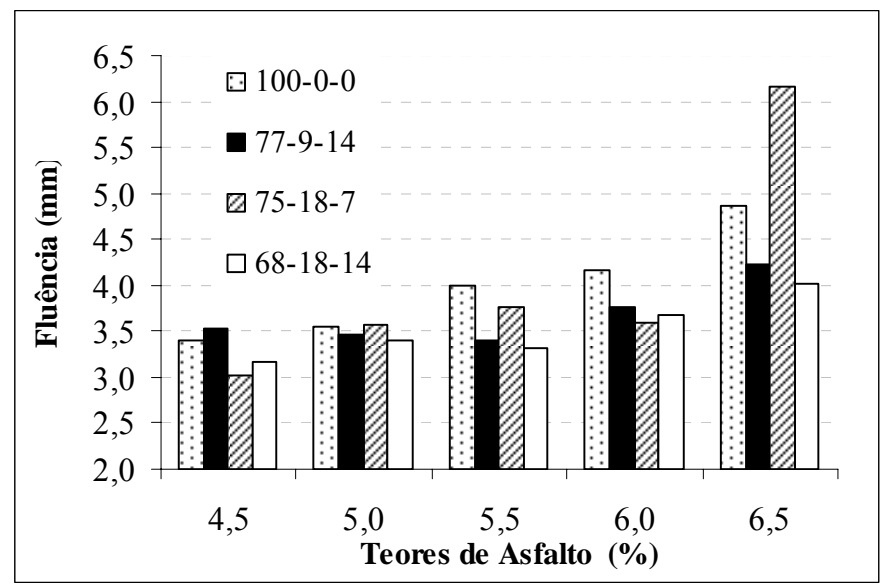

Figura 4.4: Fluência das misturas asfálticas com adição de óleo e borracha.

Observa-ser da Figura 4.4 que a mistura com adição de $9 \%$ de borracha e 14\% de óleo apresenta valores de fluência menores do que a mistura de referência, com exceção do teor de $4,5 \%$ de ligante, que apresentou um aumento de $4 \%$ na fluência. O mesmo comportamento é observado para a mistura com adição de $18 \%$ de borracha e $7 \%$ de óleo; no entanto, essa mistura apresentou maiores valores de fluência nos teores de 5,0\% e 6,5\%, com aumentos de $1 \%$ e $27 \%$, respectivamente. Da mesma maneira que as misturas anteriores, a que possui $18 \%$ de borracha e $14 \%$ de óleo apresenta redução nos valores de fluência, sendo que para o teor de $6,5 \%$ houve a menor redução $(17 \%)$.

Em relação à fluência pode-se dizer que o óleo e a borracha apresentam mesmo comportamento, diminuindo o valor da propriedade. Somente as misturas com adição de borracha apresentaram tendência definida em relação ao aumento do teor de ligante asfáltico, diminuindo o valor da fluência.

\subsection{Ensaios das Propriedades Mecânicas}

\subsubsection{Módulo de Resiliência}

Os ensaios de módulo de resiliência das misturas de referência e experimentais deste estudo foram realizados a $25^{\circ} \mathrm{C}$, conforme procedimento de ensaio indicado no item 2.5.2 do capítulo 2. Na Figura 4.5 são mostrados os resultados comparativos dos módulos de resiliência total 
das misturas de referência e modificadas. Os demais resultados desses ensaios estão apresentados no Apêndice C.

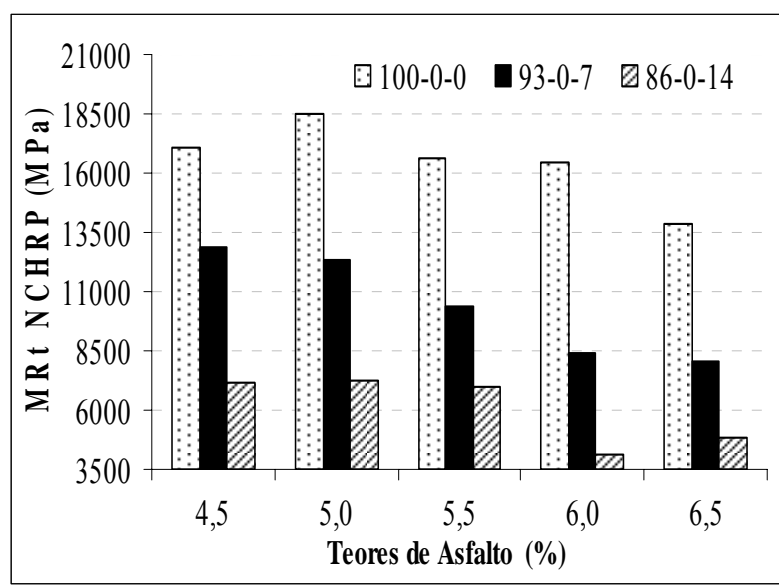

(a)

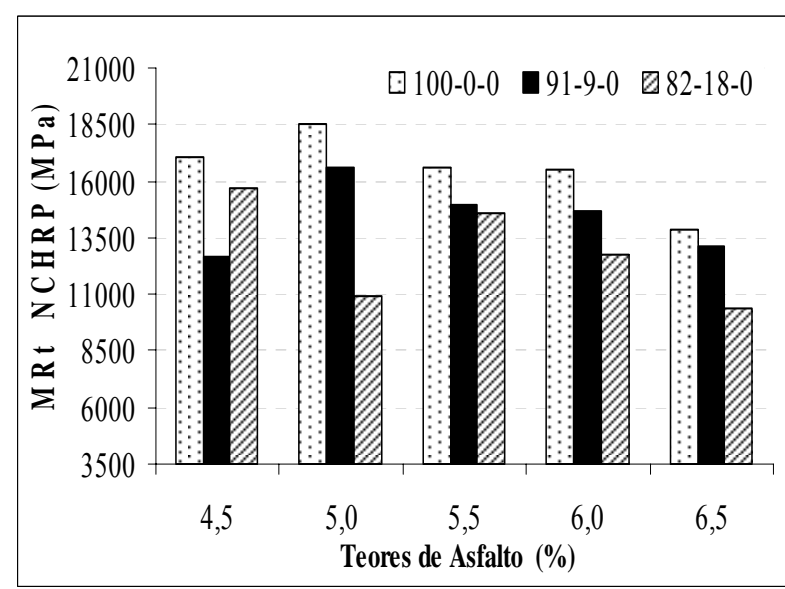

(b)

Figura 4.5 Módulo de resiliência total das misturas: (a) adição de óleo e (b) adição de borracha

As misturas com adição de óleo apresentam menores valores de módulo de resiliência total em relação à mistura de referência, conforme mostra a Figura 4.5 (a). O aumento de 7\% para $14 \%$ de óleo proporciona uma redução significativa no valor da propriedade. A maior redução ocorreu na mistura 86-0-14 para o teor asfáltico de 6,0\%, com diminuição de 75\% do módulo total em relação ao obtido na mistura de referência. A mistura com adição de 7\% de óleo apresenta uma redução nos valores de módulo de resiliência quando se aumenta o teor de ligante asfáltico, porém o mesmo comportamento não é observado para a mistura com adição de $14 \%$ de óleo.

Da mesma maneira que o óleo, a adição de borracha também proporciona uma diminuição no valor do módulo de resiliência total das misturas; no entanto, com menor intensidade, conforme é mostrado na Figura 4.5 (b). Para a mistura com adição de 9\% de borracha, a maior redução do valor do módulo de resiliência está no teor de asfalto de $4,5 \%$, com diminuição de $26 \%$ em relação ao da mistura de referência. A mesma mistura não apresentou uma tendência definida com relação ao aumento do teor de ligante asfáltico. O mesmo comportamento é observado na mistura com adição de $18 \%$ de borracha. O aumento na adição de borracha, de $9 \%$ para $18 \%$, também apresentou uma diminuição no valor do módulo, com exceção no teor de $4,5 \%$ de ligante, onde ocorreu um aumento de $19 \%$ no valor do módulo. 
Apesar dos dois modificadores reduzirem o valor do módulo de resiliência, constata-se que o efeito do óleo é mais intenso que o da borracha, pois o mesmo proporcionou reduções maiores nos valores de módulo em comparação aos da mistura de referência.

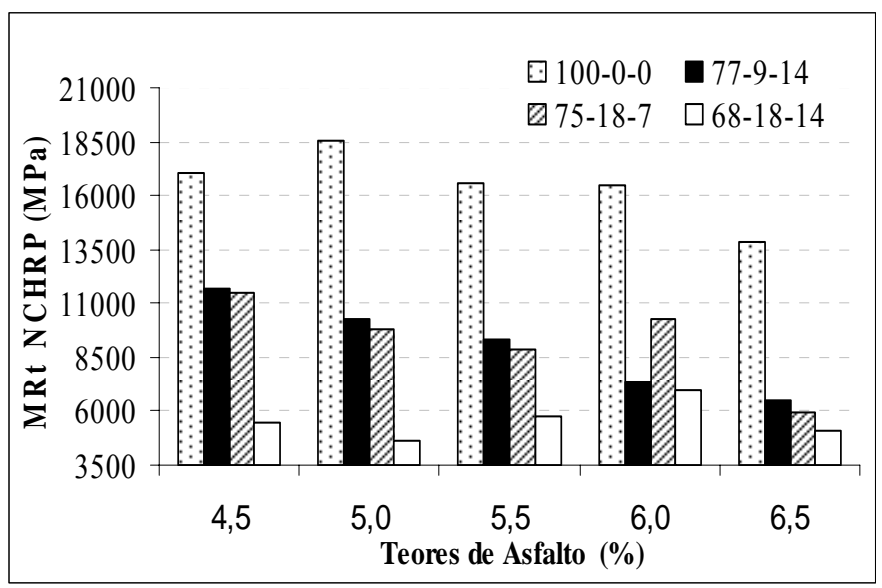

Figura 4.6 Módulo de resiliência total das misturas com adição de óleo e borracha

A Figura 4.6 mostra o comportamento das misturas com adição dos dois componentes, borracha e óleo. Pode-se observar que todas as misturas apresentaram valores inferiores de módulo de resiliência em relação aos da mistura de referência. A mistura 82-18-14, no teor de $5,0 \%$, apresentou o menor valor de módulo, com redução de $75 \%$ do valor em relação ao de referência. A única mistura que apresentou tendência de redução do valor do módulo à medida que se aumenta o teor de ligante asfáltico foi aquela com adição de $9 \%$ de borracha e 18\% de óleo; as outras não apresentaram um comportamento definido.

Com base nos resultados apresentados e analisados anteriormente, verifica-se que ocorre uma queda razoavelmente grande do valor do módulo de resiliência das misturas com adição de óleo e borracha. A adição do óleo proporciona uma mistura menos viscosa e a incorporação da borracha torna a mistura asfáltica mais elástica, o que justificaria essa diminuição. As misturas com adição de teores altos dos dois modificadores apresentaram os menores valores de módulo, apontando que à medida que aumentam os teores de borracha e óleo ocorre diminuição no valor dessa propriedade. Cabe ressaltar que o comportamento dos valores do módulo instantâneo das misturas estudadas é similar ao do módulo total aqui apresentado. 


\subsubsection{Resistência à Tração por compressão diametral}

A Figura 4.7 mostra os valores obtidos dos ensaios de resistência à tração das misturas com adição somente de óleo ou borracha. Os demais dados deste ensaio estão apresentados no Apêndice D.

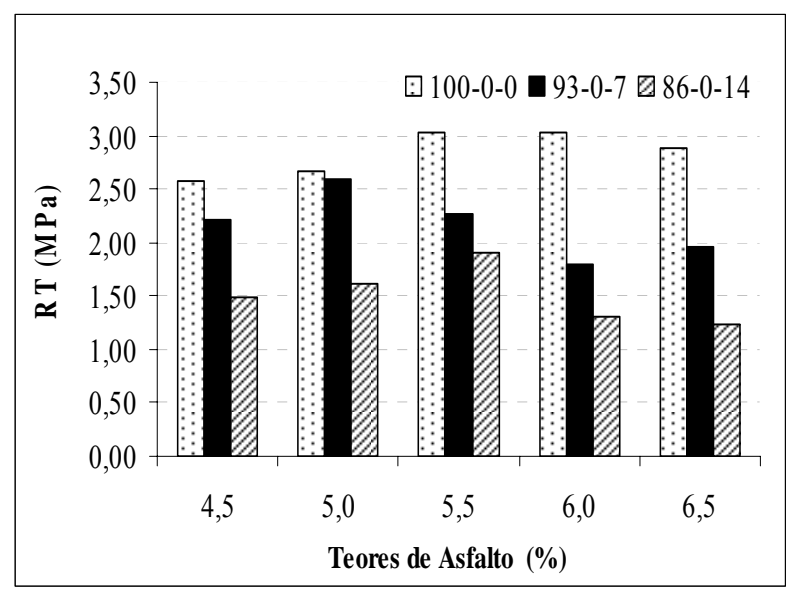

(a)

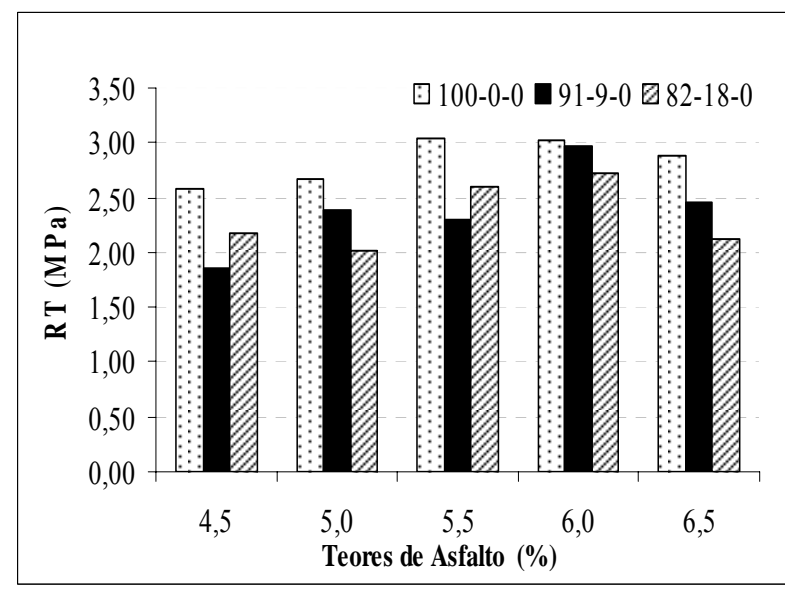

(b)

Figura 4.7 Resistência à tração das misturas: (a) adição de óleo e (b) adição de borracha

Assim como no módulo de resiliência, o óleo causa o mesmo comportamento quando analisada a propriedade de resistência à tração, como mostra a Figura 4.7 (a). Nela nota-se que da adição de $7 \%$ para a de $14 \%$ de óleo há uma diminuição mais intensa dos valores de resistência à tração. A maior redução é apresentada pela mistura com adição de $14 \%$ de óleo, nos teores de $6,0 \%$ e $6,5 \%$, onde o valor dessa propriedade é reduzido em 57\%, aproximadamente, em relação ao valor da mistura de referência. Essa mesma mistura (14\% de óleo), com o aumento no teor de ligante asfáltico, apresenta um aumento da resistência à tração até o teor de 5,5\% e uma redução para os teores mais altos. No entanto, a outra mistura (7\% de óleo) não mostra uma tendência definida.

Os efeitos do óleo e da borracha são semelhantes na resistência à tração; ambos proporcionam a redução no valor dessa propriedade. O comportamento da borracha é apresentado na Figura 4.7 (b). No gráfico observa-se que para mistura com adição de $9 \%$ de borracha, o menor valor de resistência à tração é de $1,86 \mathrm{MPa}$, no teor de 4,5\% de ligante asfáltico. A redução da propriedade, neste caso, foi de $28 \%$ em relação ao valor obtido para a mistura de referência. 
No entanto, para misturas com teor de 6,0\% de ligante, o valor de resistência à tração não teve alteração significativa, apresentando, apenas, uma redução de $2 \%$.

$\mathrm{Na}$ adição de $18 \%$ de borracha, a mistura que apresentou o menor valor de resistência à tração foi a que tem teor de ligante asfáltico igual a 6,5\%, com um valor igual a 2,13MPa, 26\% inferior ao de referência. $\mathrm{O}$ aumento na proporção de borracha adicionada à mistura, com exceção dos teores de $4,5 \%$ e $5,5 \%$, causou uma maior redução no valor da resistência à tração; entretanto, não há tendência definida quanto ao aumento no teor de ligante na resistência à tração. De maneira geral, pode-se verificar que a adição de óleo tem efeito mais intenso na redução da resistência à tração do que a adição de borracha.

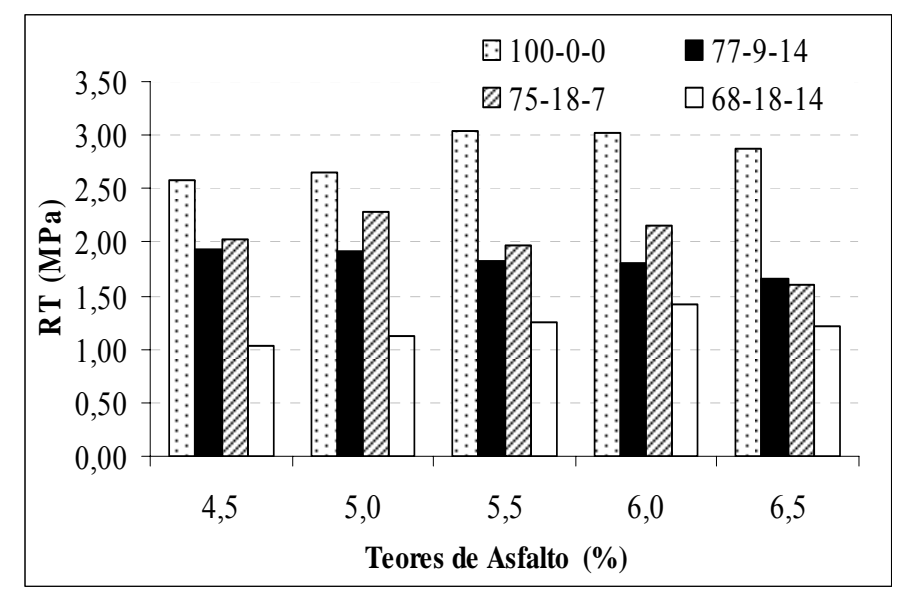

Figura 4.8 Resistência à tração das misturas com adição de óleo e borracha

A Figura 4.8 mostra os valores de resistência à tração para as misturas com adição dos dois modificadores. Conclui-se que as misturas com altas concentrações de óleo apresentaram os menores valores de resistência à tração em relação à mistura de referência. Apesar da mistura com adição de $18 \%$ de borracha e $7 \%$ de óleo apresentar menores valores de resistência à tração em relação aos da de referência, estas foram as menores reduções quando comparadas às das outras misturas modificadas.

No entanto, para a mistura com adição de altas concentrações de óleo e borracha $(18 \%$ e $14 \%$, no teor de ligante asfáltico de $4,5 \%$, houve redução no valor da resistência à tração de $60 \%$. Cabe ressaltar que os valores de resistência à tração da mistura 77-9-14 não apresentaram grandes variações com o aumento do teor de ligante asfáltico. Da mesma forma, 
as demais misturas não apresentaram uma tendência definida de comportamento da resistência à tração com o aumento do teor de ligante asfáltico.

A redução significativa da RT encontrada nas misturas estudadas também foi verificada por Faxina (2002) em misturas similares, que apontaram valores de RT para misturas com asfaltoborracha-óleo até 40\%menores que os valores de referência. A diminuição dos valores de MR e RT encontrados no presente trabalho também foram obtidos em outros estudos que, assim, corroboraram os resultados da presente pesquisa (PINHEIRO, 2004; MOMM e SALINI, 2000; e GALLEGO et al., 2000.

\subsubsection{Relação MR/RT}

A relação $\mathrm{MR} / \mathrm{RT}$ foi utilizada, por muito tempo, para a visualização da compatibilidade entre rigidez e resistência à tração da mistura asfáltica; misturas muito rígidas necessitam de uma alta resistência à tração devido a concentração de esforços em seu interior. A Figura 4.9 apresenta a relação MR/RT para as misturas com adição somente de óleo ou de borracha. Os dados referentes a esse ensaio estão detalhados no Apêndice E.

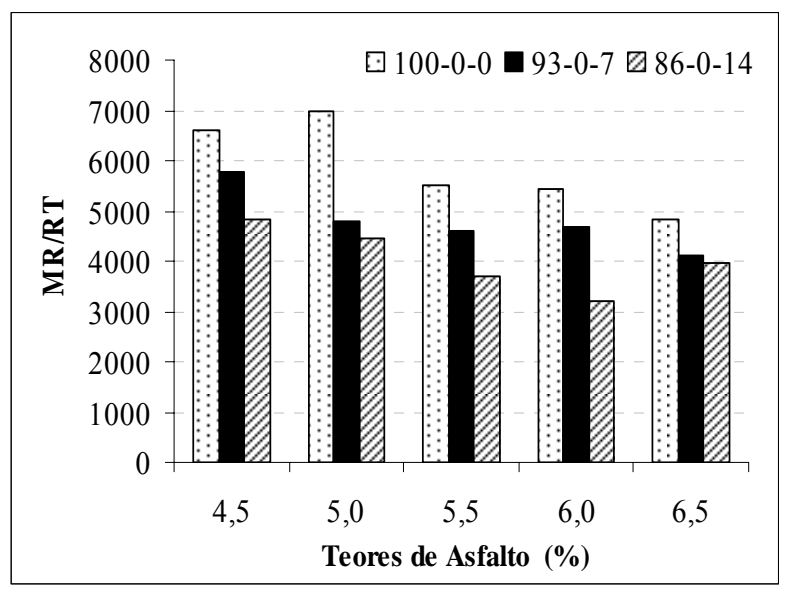

(a)

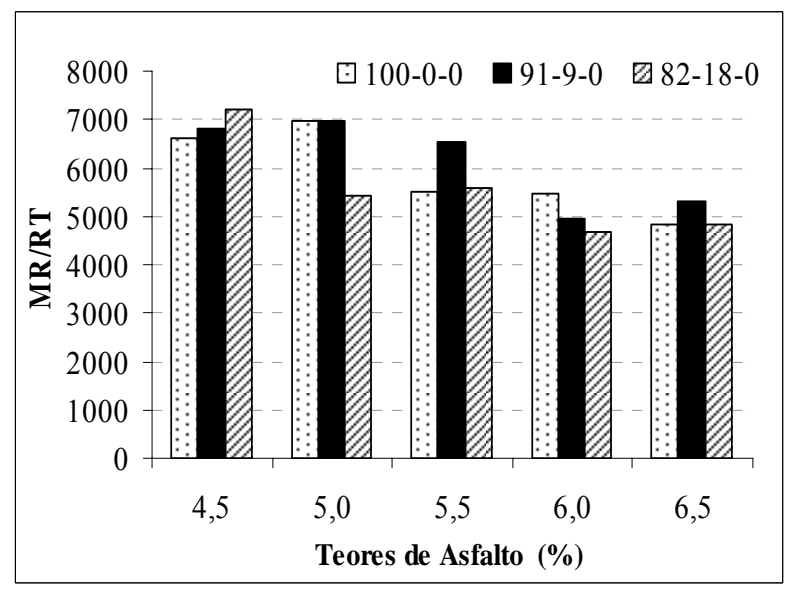

(b)

Figura 4.9 Relação MR/RT das misturas: (a) adição de óleo e (b) adição de borracha

A adição de óleo nas misturas proporcionou a diminuição da relação MR/RT, conforme apresenta a Figura 4.9 (a). Cabe ressaltar que em comparação aos demais teores, o teor de $6,5 \%$, apresentou a menor diferença absoluta na relação MR/RT (aproximadamente 4\%) 
quando aumentada a proporção de $7 \%$ para $14 \%$ de óleo na mistura. De maneira similar às demais propriedades analisadas anteriormente, não há uma tendência definida quanto ao comportamento da relação MR/RT com o aumento do teor de ligante asfáltico.

A Figura 4.9 (b) mostra os dados referentes à relação MR/RT das misturas com adição de borracha. Pode-se observar que em alguns teores de asfalto, 4,5\%, 5,0\%, 5,5\% e 6,5\%, as misturas com adição de $9 \%$ de borracha apresentaram valores superiores da relação MR/RT em relação aos valores da de referência. Apenas no teor de $6,0 \%$ essa mistura apresentou redução dessa relação ( $9 \%$ de redução). Na mistura com adição de $18 \%$ de borracha nota-se a redução da relação $\mathrm{MR} / \mathrm{RT}$ para os teores de 5,0\% e 6,0\%, com diminuição de $22 \%$ e $14 \%$, respectivamente. No teor de 4,5\% observa-se um aumento de $9 \%$ no valor da relação, enquanto que nos teores de 5,5\% e 6,5\% não ocorreu uma mudança nos valores quando comparados aos da mistura de referência. Com o aumento da proporção de $9 \%$ para $18 \%$ de borracha na mistura, somente no teor de 4,5\% nota-se um aumento da relação MR/RT; nos demais teores observa-se redução nos valores.

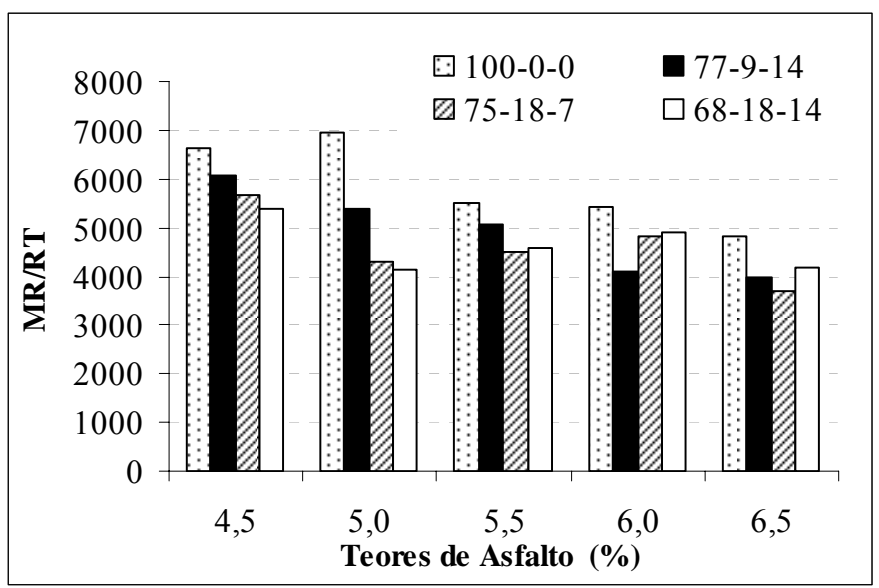

Figura 4.10 Relação MR/RT das misturas: com adição de óleo e borracha

Os dados referentes à relação MR/RT das misturas com a adição dos dois componentes (óleo e borracha) estão apresentados na Figura 4.10. A adição dos dois modificadores nas misturas proporciona menores valores na relação MR/RT quando comparados aos da mistura de referência. Quando comparada às outras misturas modificadas, a mistura 77-9-14 apresentou as menores reduções dessa relação, com exceção dos teores de 6,0\% e 6,5\%. A mistura com adição de altas concentrações de óleo e de borracha apresentou os menores valores dessa 
relação somente nos teores de 4,5\% e 5,0\%, proporcionando com reduções de $19 \%$ e $40 \%$, respectivamente.

Para a relação $\mathrm{MR} / \mathrm{RT}$ pode-se mencionar que a adição de óleo faz com que essa relação diminua. Já para a incorporação de borracha o efeito, em geral, é contrário, aumentando essa relação. As misturas com adição dos dois componentes apresentaram redução da relação MR/RT em todos os casos. Cabe ressaltar que os valores encontrados para a relação MR/RT, em todas as misturas, são superiores a 3000 .

\subsubsection{Recuperação Retardada}

A recuperação retardada (RR) representa a porção da recuperação do ciclo de repouso, no qual se encontra mobilizada a recuperação visco-elástica, conforme definido por Furlan (2006). Na Figura 4.11 são mostradas as RR das misturas com adição de óleo ou borracha. Maiores detalhes desse parâmetro estão expostos no Apêndice F.

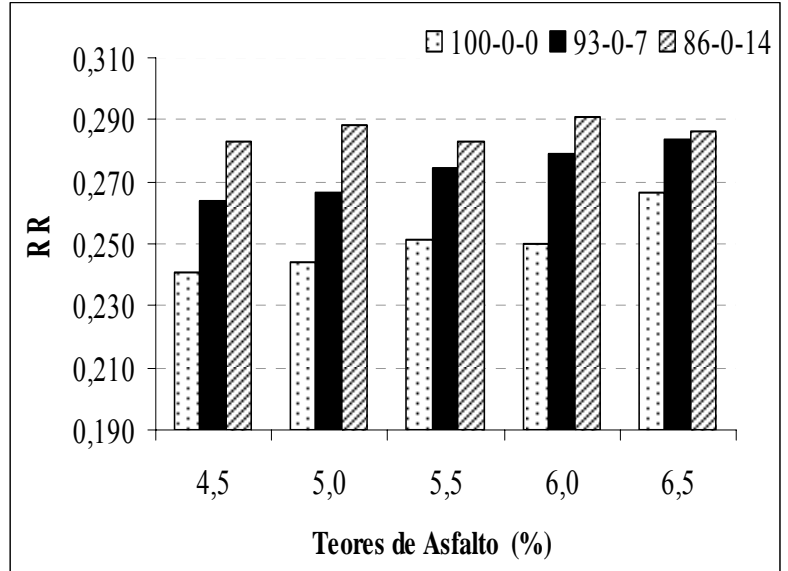

(a)

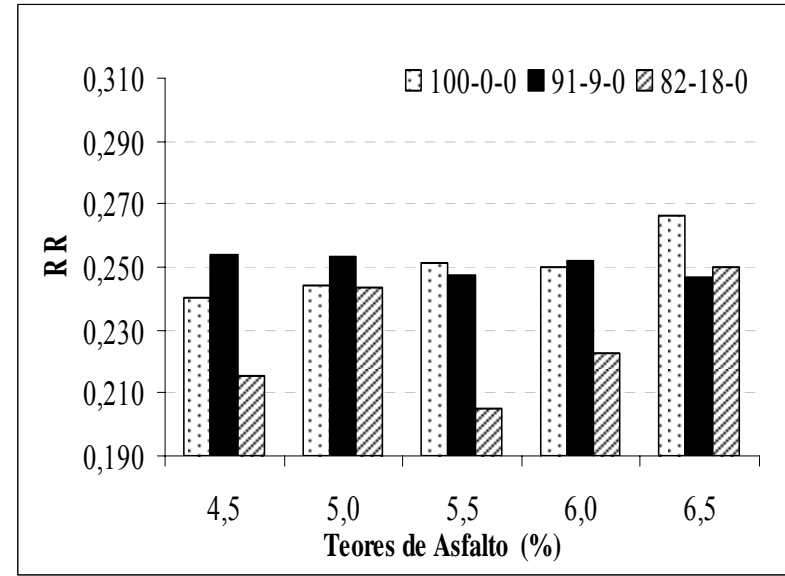

(b)

Figura 4.11 Recuperação retardada das misturas: (a) adição de óleo e (b) adição de borracha

Observa-se através da Figura 4.11 (a) que a adição de óleo nas misturas proporciona um aumento na recuperação retardada. Esse parâmetro apresentou uma variação de 6\% (na mistura com adição de 7\% de óleo, no teor de 4,5\% de ligante) a 18\% (na mistura com adição de $14 \%$ de óleo, nos teores de $4,5 \%$ e $5,0 \%$ de ligante). Nota-se o aumento da recuperação retardada quando se aumenta a proporção de $7 \%$ para $14 \%$ de óleo. A adição de óleo 
proporciona uma redução da parcela elástica da mistura, portanto, apresenta uma deformação elástica instantânea menor, o que justifica o aumento da recuperação retardada.

Os dados referentes às misturas com adição de borracha são mostrados na Figura 4.11 (b). Nela pode-se notar que a adição de borracha na mistura propicia uma diminuição da recuperação retardada, com exceção da mistura com adição de $9 \%$ de borracha nos teores de $4,5 \%, 5,0 \%$ e $6,0 \%$. O valor desse parâmetro variou de $1 \%$ (na mistura com adição de $9 \%$ de borracha, no teor de 5,5\%) a $18 \%$ (na mistura com adição de $18 \%$ de borracha, no teor de 5,5\%). Uma possível explicação para esse comportamento contrário ao da adição do óleo pode se basear no fato que a adição da borracha na mistura asfáltica a torna mais elástica, proporcionando um aumento no valor da deformação elástica instantânea e, conseqüentemente, uma diminuição no valor da recuperação retardada.

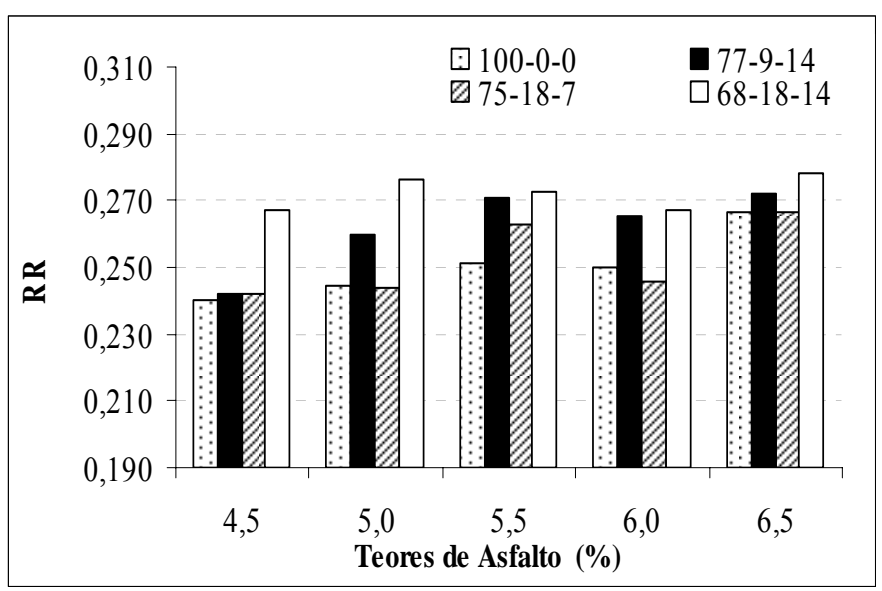

Figura 4.12 Recuperação retardada das misturas com adição de óleo e borracha

Pode-se observar da Figura 4.12 que a adição dos dois modificadores propicia um aumento da recuperação retardada. Nota-se que no teor de 4,5\% apenas a mistura com adição de altas concentrações dos modificadores teve um aumento significativo do parâmetro, apresentando uma variação de $11 \%$. As misturas com adição de altas concentrações de modificadores apresentaram os maiores valores da RR, seguidas pela mistura com adição de valores intermediário de borracha e alto de óleo, e pelas mistura com concentrações alta de borracha e intermediária de óleo. Cabe ressaltar que a adição somente de óleo apresenta os maiores valores de recuperação retardada quando comparados com os das demais misturas analisadas. 
Ao analisar o parâmetro da recuperação retardada pode-se concluir que borracha e óleo proporcionam efeitos contrários, sendo que a adição de óleo proporciona o aumento da RR enquanto a adição da borracha propicia a sua diminuição, quando comparados aos valores da mistura de referência.

\subsection{Propriedades das misturas pós-condicionamento}

A apresentação dos resultados será de maneira similar à utilizada no item 4.2. Para melhor compreensão serão comparados dados das misturas pré-condicionadas e pós-condicionadas. A apresentação, de forma geral, será realizada através do gráfico de relação de resistência à tração (RRT), que representa a taxa de retenção dessa propriedade depois de realizado o condicionamento, e do gráfico que apresenta a relação de módulo de resiliência (RMR) que, da mesma maneira que a RRT, representa a retenção dessa propriedade após o condicionamento. Os demais dados referentes a esses ensaios estão apresentados no Apêndice G.

\subsubsection{Módulo de Resiliência pós-condicionamento}

A Figura 4.13 mostra os dados referentes ao módulo de resiliência das misturas condicionadas e não condicionadas. Os demais dados então apresentados na Tabela G1 no apêndice G.

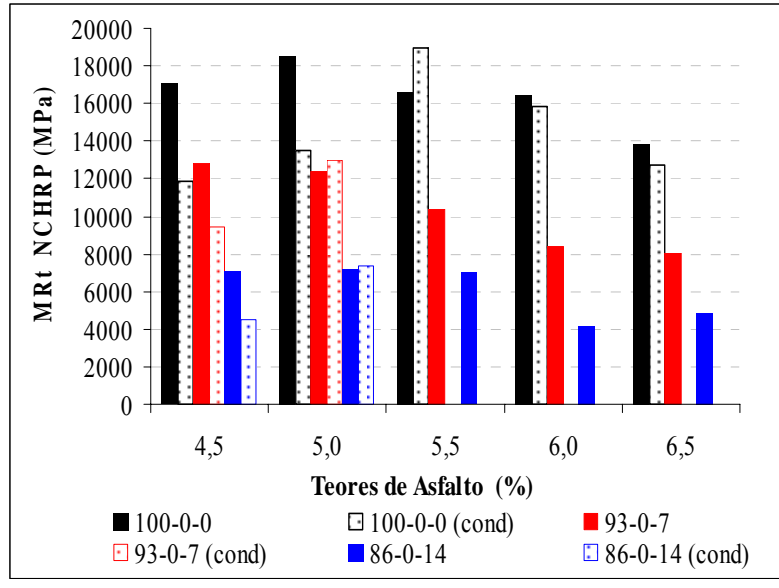

(a)

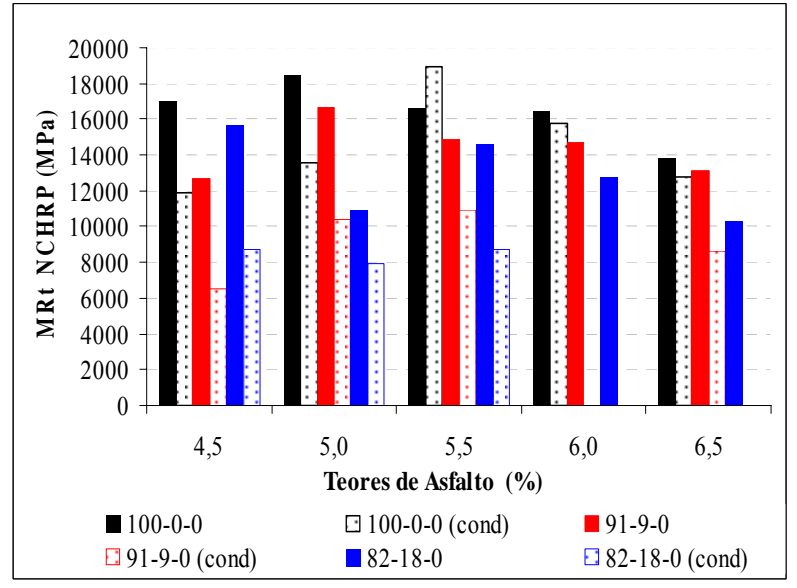

(b)

Figura 4.13 MRt das misturas condicionadas e não-condicionadas: (a) adição de óleo e (b) adição de borracha 
Considerando os dados apresentados na Figura 4.13 (a), observa-se que o módulo de resiliência das misturas com adição de óleo diminuiu após o condicionamento, com exceção de três misturas, a saber: mistura de referência, no teor de 5,5\%, que apresentou um aumento de $14 \%$ na propriedade, mistura com adição de 7\% de óleo, no teor de 5,0\%, com aumento de $5 \%$ nessa propriedade e na mistura com adição de $14 \%$ de óleo, no teor de 5,0\%, com variação de $2 \%$ na propriedade. Nota-se maior redução do módulo de resiliência na mistura com adição de 14\% de óleo, que proporcionou uma redução de 37\% nessa propriedade.

Na Figura 4.13 (b) são apresentados os dados referentes ao módulo de resiliência das misturas com adição de borracha. Percebe-se que as misturas com adição de borracha tiveram uma diminuição no valor do módulo depois de realizado o condicionamento. As reduções nos valores dessa propriedade variaram de $27 \%$ (redução encontrada nas misturas com adições de $9 \%$ e $14 \%$, nos teores de $5,5 \%$ e $5,0 \%$, respectivamente) a $48 \%$ na mistura com adição de $9 \%$ de borracha no teor de ligante asfáltico de $4,5 \%$.

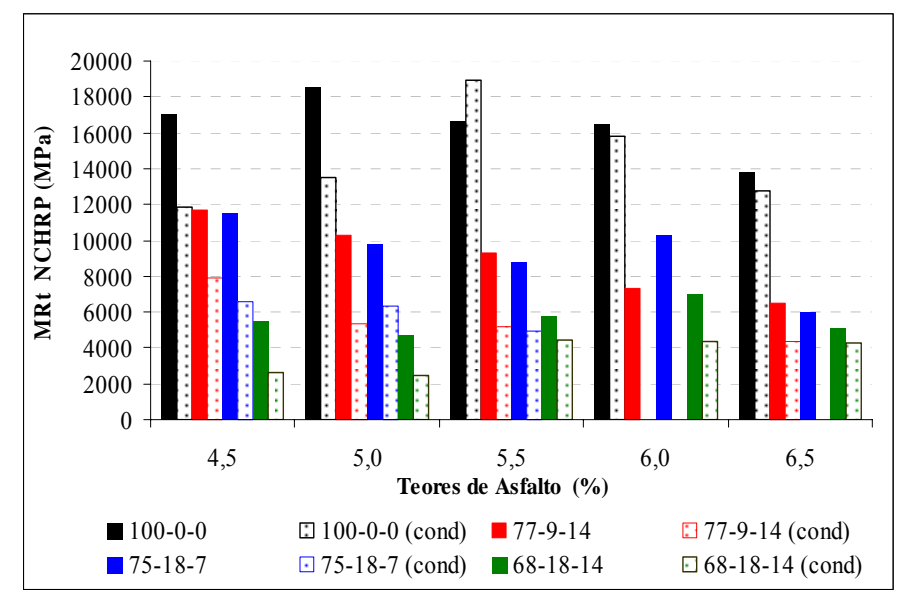

Figura 4.14 MRt das misturas condicionadas e não-condicionadas com adição de óleo e borracha

Os dados apresentados na Figura 4.14 concordam com os anteriores. Observa-se que as misturas com adição dos modificadores exibem perda de propriedade em todos os casos. A maior perda é observada na mistura com adição de altas concentrações dos dois componentes, $14 \%$ de óleo e $18 \%$ de borracha, com diminuição de $52 \%$ no valor da propriedade. No entanto, a mistura de referência no teor de 5,5\% apresentou ganho de rigidez após o condicionamento. 
Para melhor visualizar o comportamento das misturas estudadas, na Figura 4.15, são apresentadas as relações de módulo de resiliência (RMR). Os detalhes desses dados estão apresentados na Tabela G2 no apêndice G. Foi utilizado um valor de RMR=70\% para definir uma linha hipotética de suscetibilidade, como já utilizado por Furlan (2006). Essa linha é adicionada ao gráfico para visualizar as misturas suscetíveis e não suscetíveis aos danos por umidade.

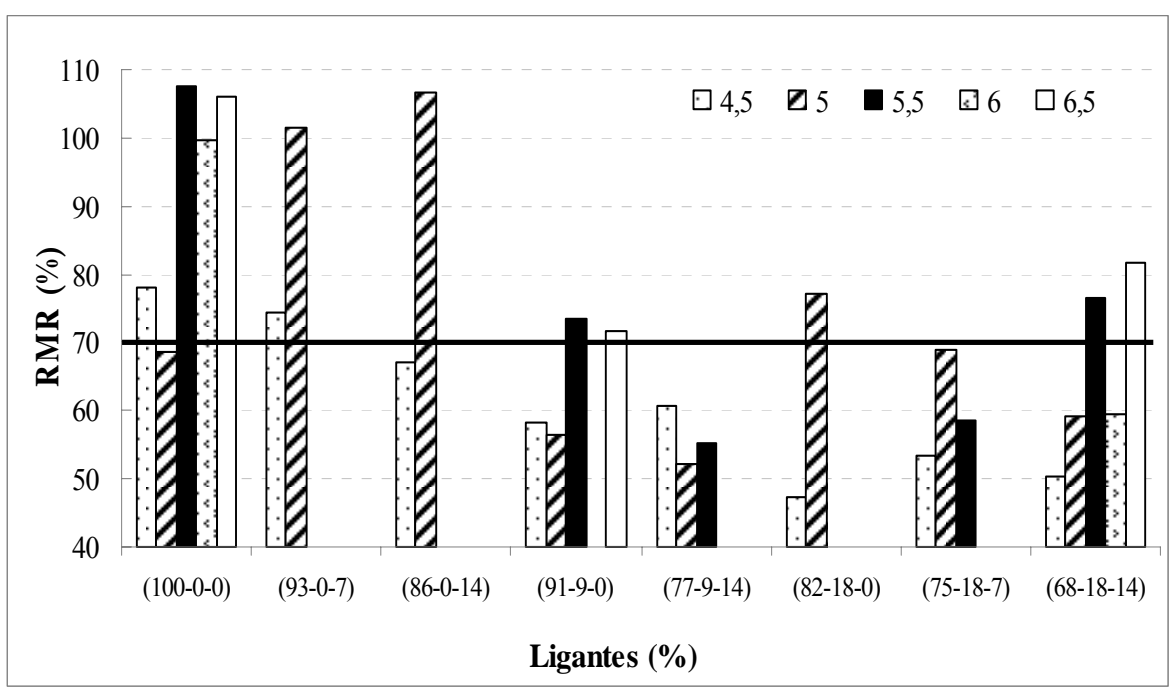

Figura 4.15 Relação de módulo de resiliência (RMR) das misturas estudadas

Da Figura 4.15 pode-se observar que o efeito do condicionamento nas misturas asfálticas propiciou, na maioria dos casos, uma diminuição da sua rigidez, expressa na diminuição dos valores de módulo de resiliência. No entanto, observa-se o comportamento contrário de algumas misturas, como por exemplo, com adição de $7 \%$ de óleo que apresentou aumento do módulo após o condicionamento.

\subsubsection{Resistência à Tração pós-condicionamento}

A Figura 4.16 apresenta uma comparação entre os valores de resistência à tração das misturas pré-condicionamento e pós-condicionamento. 


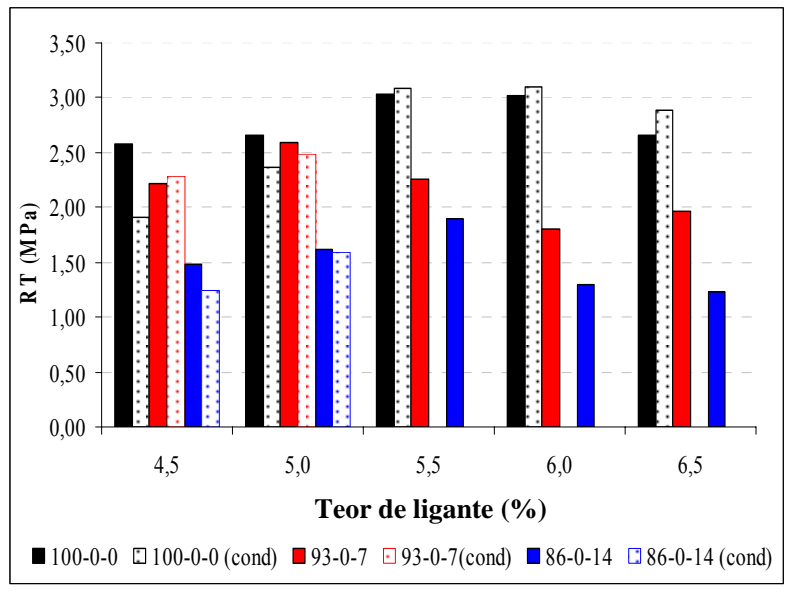

(a)

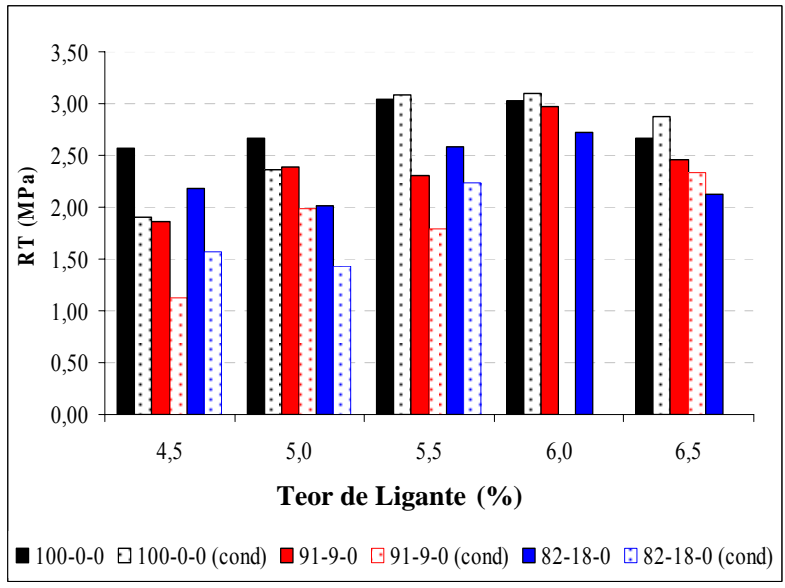

(b)

Figura 4.16 Resistência à tração das misturas condicionadas e não condicionadas: (a) adição de óleo e (b) adição de borracha

Como pode ser observado, na Figura 4.16 (a), ocorre uma queda dessa propriedade após o condicionamento. Nota-se que nos teores de 5,5\%,6,0\% e 6,5\% a mistura de referência apresentou maior resistência depois de condicionada. Esse mesmo comportamento é observado para a mistura com adição de $7 \%$ de óleo, no teor de $4,5 \%$, com aumento de $3 \%$ na resistência. No entanto, a mistura com adição de $14 \%$ de óleo, no teor de 4,5\%, apresentou o menor valor de resistência, com redução de $16 \%$ nessa propriedade.

Na Figura 4.16 (b) é possível observar que todas as misturas com adição de borracha tiveram os valores de resistência à tração reduzidos depois do condicionamento. A mistura com adição de $9 \%$ de borracha, no teor de 4,5\%, apresentou o menor valor de resistência à tração $(1,12 \mathrm{MPa})$, com redução de $40 \%$ no valor da propriedade após o condicionamento. Pode-se destacar que o efeito da borracha é mais intenso que o do óleo, pois as misturas com adição de borracha apresentaram valores de resistência menores. 


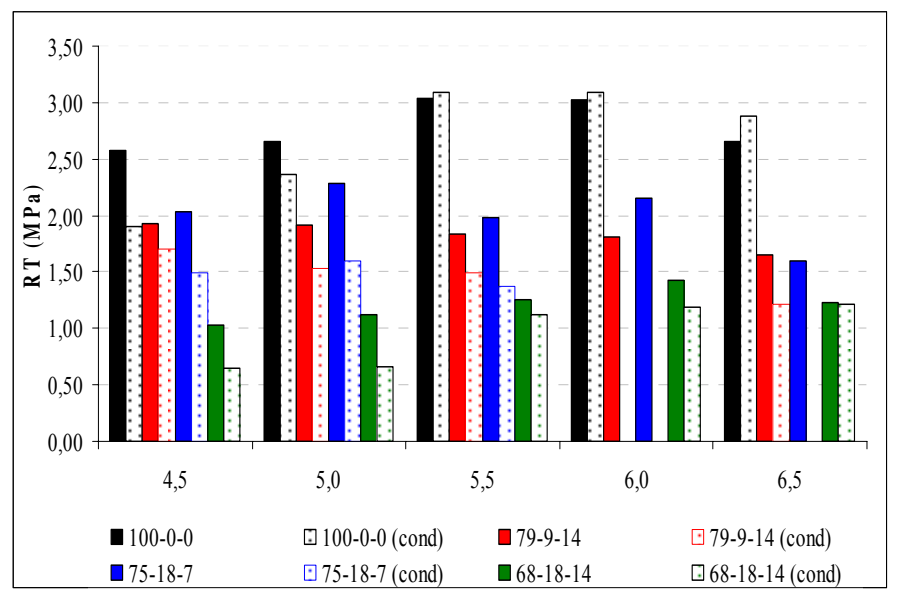

Figura 4.17 Resistência à tração das misturas condicionadas e não condicionadas com adição de óleo e borracha

Considerando que os efeitos do óleo e da borracha são similares, reduzindo a resistência à tração após o condicionamento, é razoável afirmar que os valores da resistência das misturas com adição dos dois modificadores sejam menores depois de realizado o condicionamento, conforme mostra a Figura 4.17. Apenas a mistura com adição de altas concentrações dos modificadores, no teor de ligante asfáltico de $6,5 \%$, não sofreu alteração no valor da resistência.

Para visualizar os comportamentos das misturas estudadas, na Figura 4.18 são mostradas as relações de resistência à tração (RRT) e a linha de suscetibilidade em RRT=70\%, como realizado anteriormente para a RMR.

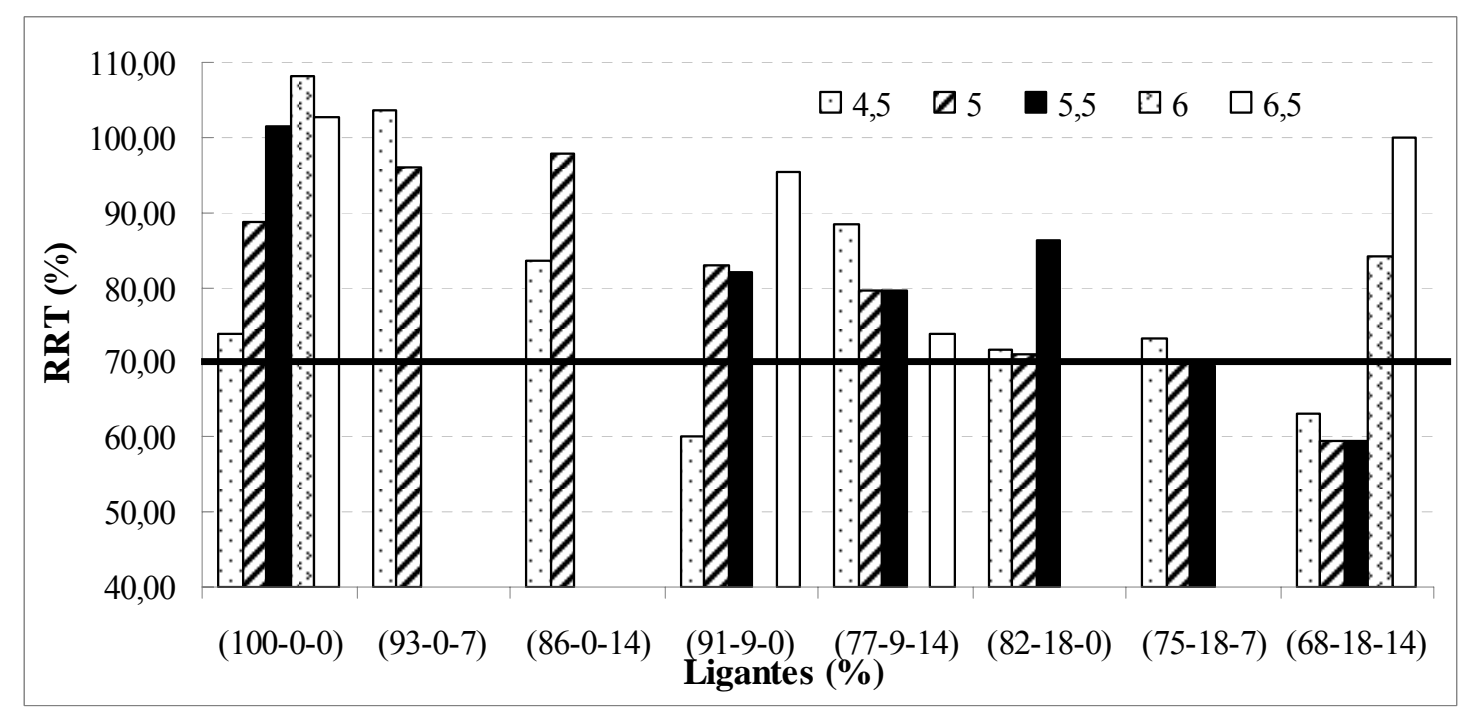

Figura 4.18 Relação de resistência à tração (RRT) das misturas asfálticas estudadas 
Através da Figura 4.18 pode-se observar o comportamento de cada mistura asfáltica em conseqüência do condicionamento. Quanto ao dano por umidade induzida pode-se dizer que as misturas com adição de óleo foram menos suscetíveis ao condicionamento. As misturas com adição de borracha foram pouco suscetíveis ao condicionamento, com exceção da mistura com teor de ligante asfáltico de 4,5\%. Para as misturas com adição dos dois modificadores apenas a mistura com proporções altas de óleo e borracha, nos teores de 4,5\% a $5,5 \%$, foi mais suscetível ao dano por umidade.

Se fosse considerada a taxa mínima de retenção de resistência à tração de $70 \%$, as misturas estudadas que seriam consideradas suscetíveis ao dano por umidade seriam:

- Mistura com adição de $9 \%$ de borracha no teor de ligante asfáltico de 4,5\%;

- Mistura com adição de $18 \%$ de borracha e $7 \%$ de óleo, no teor de 5,5\%; e

- Mistura com adição de altas concentrações dos dois componentes (18\% e 14\%), nos teores de 4,5\%, 5,0\% e 5,5\%. Cabe ressaltar que as misturas no teor de 5,0\% e 5,5\% apresentam as maiores perdas da propriedade

\subsubsection{Recuperação retardada}

Os dados referentes à recuperação retardada das misturas depois de condicionadas então apresentados na Figura 4.19.

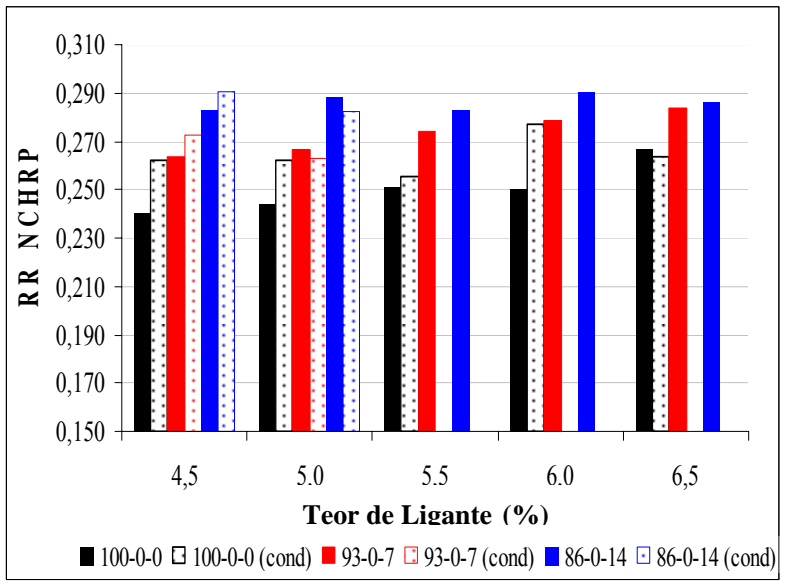

(a)

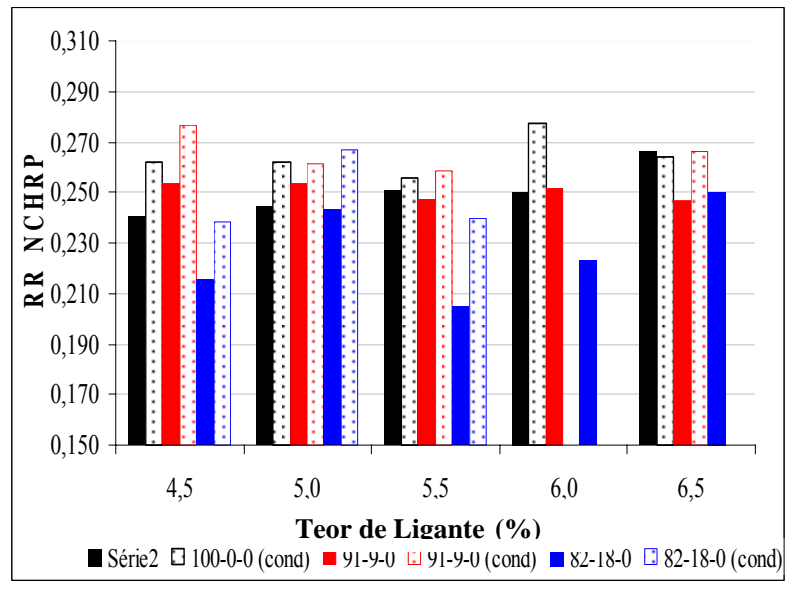

(b)

Figura 4.19 Recuperação retardada das misturas condicionadas e não condicionadas: (a) adição de óleo e (b) adição de borracha 
Observa-se da Figura 4.19 (a) que depois do condicionamento das misturas com adição de óleo apresentaram, de maneira geral, aumento no valor da recuperação retardada, com exceção das misturas com teor de 5,0 \% de ligante asfáltico. Para as misturas com adição de borracha, conforme mostra a Figura 4.19 (b) nota-se que ocorre aumento da recuperação retardada em todas as misturas.

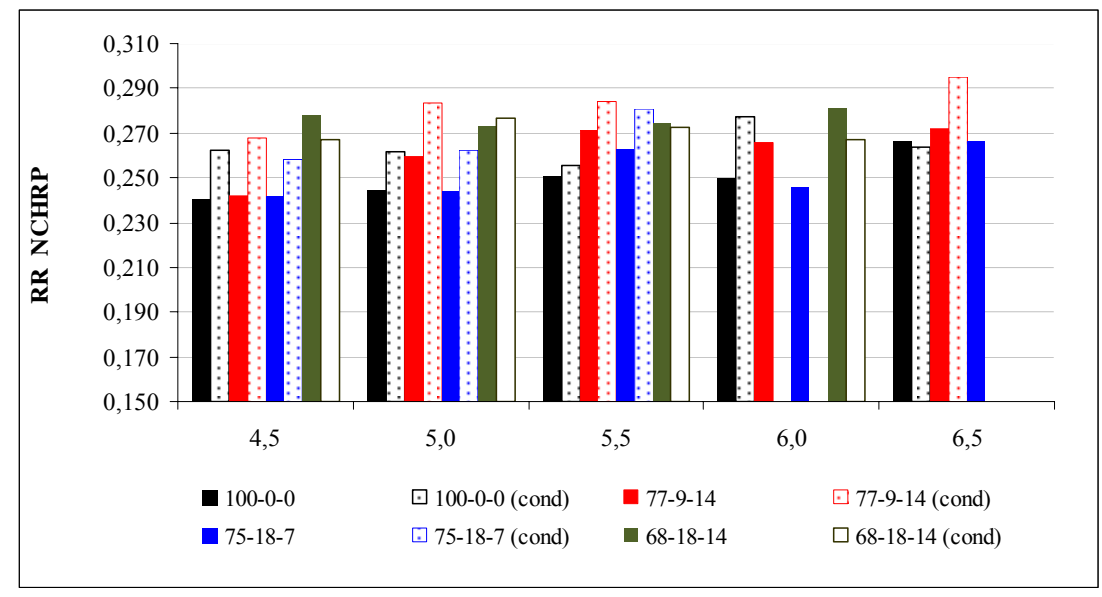

Figura 4.20 Recuperação retardada das misturas condicionadas e não condicionadas com adição de óleo e borracha

A Figura 4.20 mostra os resultados referentes à recuperação retardada das misturas com adição dos dois componentes. Pode-se notar que com exceção da mistura com concentrações altas de borracha e óleo (68-18-14), as demais apresentaram maiores valore de recuperação retardada para todos os teores de ligantes estudados.

\subsection{Análise Estatística dos Resultados}

O objetivo item e dos subsequêntes é apresentar os procedimentos adotados para a análise estatística dos resultados ensaiados. A análise foi baseada no estudo de modelos estatísticos lineares polinomiais, do tipo cúbico especial, efetuado mediante o pacote estatístico Minitab versão 15.1. Com base nos modelos obtidos foram gerados gráficos de superfície de resposta e efeito de componentes pelo pacote estatístico, os quais são analisados. 


\subsubsection{Procedimento de Análise}

O delineamento do experimento e a análise estatística pressupõem que o agregado mineral é um material inerte e que a variabilidade das propriedades obtidas das misturas asfálticas está, exclusivamente, atrelada às variações nas proporções dos componentes dos ligantes asfálticos. Os resultados obtidos são empregados no ajuste de modelos polinomiais voltados para a modelagem de problemas com misturas, os quais descrevem a variabilidade de uma propriedade em função das variações nas proporções dos componentes das misturas.

A avaliação das propriedades é realizada através dos gráficos de efeito de componentes e de superfícies de resposta. São delimitadas áreas do espaço amostral, baseadas em especificações de ligantes asfálticos não-modificados, que determinem amostras de misturas asfaltoborracha-óleo que atendem aos requisitos dessas especificações. A opção por modelos lineares do tipo polinomial foi escolhida pois o estudo em questão é típico de experimentos com misturas, que são normalmente modelados por polinômios (CORNELL, 2002). Um modelo polinomial do tipo cúbico especial é composto de sete termos que descrevem as interações entre os componentes, permitindo uma descrição detalhada dos efeitos das variações desses componentes.

O modelo empregado na regressão, denominado modelo cúbico especial, com o formato geral é indicado na equação 4.1 .

$$
\eta=\sum_{i=1}^{\mathrm{q}} \beta_{\mathrm{i}}^{0} \mathrm{x}_{\mathrm{i}}+\sum_{\mathrm{i}<\mathrm{j}} \sum_{\mathrm{ij}}^{\mathrm{q}} \beta_{\mathrm{i}}^{0} \mathrm{x}_{\mathrm{j}}+\beta_{\mathrm{ijk}}^{0} \mathrm{x}_{\mathrm{i}} \mathrm{x}_{\mathrm{j}} \mathrm{x}_{\mathrm{k}}
$$

com $\mathrm{i}, \mathrm{j}, \mathrm{k}=1,2, \ldots \mathrm{q}$, sendo q o número de componentes da mistura, $\beta \mathrm{i}, \beta \mathrm{ij}$ e $\beta \mathrm{ijk}$ as estimativas dos coeficientes dos termos xi, xij e xijk, respectivamente, $x i$, xj e xk correspondentes aos teores de CAP, de borracha e de óleo, respectivamente.

Como citado anteriormente, os resultados da análise estatística são avaliados através dos gráficos das superfícies de resposta e de efeito dos componentes. Os gráficos de superfície de resposta mostram a relação entre a resposta e os componentes da mistura. A superfície de resposta denota um plano bidimensional, no qual os pontos que apresentam o mesmo nível resposta estão conectados formando curvas de nível. Esse tipo de gráfico é uma ferramenta 
que possibilita determinar as regiões em que o resíduo de óleo de xisto pode ser empregado juntamente com a borracha, funcionando como óleo extensor.

O efeito que cada componente, isoladamente, tem sobre a resposta é representado pelo gráfico de efeito dos componentes. Esse tipo de gráfico mostra o efeito da variação da proporção de um dado componente, mantendo a relação entre os demais constantes, ou seja, ao avaliar o efeito da variação do óleo, as proporções de asfalto e borracha na mistura também variam, porém, a relação entre eles se mantém constante. Cada linha no gráfico indica o efeito de mudar o componente correspondente em uma linha imaginária (direção) conectando a mistura de referência (normalmente o centróide da região experimental) ao vértice da região experimental e a mistura de referência ao lado oposto ao vértice.

Cabe ressaltar que a análise realizada nos gráficos de efeito de componentes é apenas uma dentre as muitas possibilidades de análise (direções). No presente trabalho, foi escolhida a direção correspondente à reta ligando o vértice ao lado oposto da região experimental, passando pelo centróide da região delimitada. Esse gráfico permite identificar o componente que mais influencia a resposta. A faixa de variação da proporção dos componentes é indicada pela amplitude horizontal. A intensidade do efeito da variação da proporção do componente na mistura sobre a propriedade analisada é indica pela amplitude vertical. Uma forma rápida de análise poderia ser através da análise da porcentagem de cada componente aumentando da direita para a esquerda, dentro da sua faixa de variação.

É preciso entender que a análise de efeitos de componentes exposta por este tipo de gráfico é apenas uma dentre muitas possibilidades de análise (várias direções). A direção escolhida, nesta análise, corresponde à reta ligando o vértice ao lado oposto da região experimental, passando pela mistura de referência, que, neste caso, é o centróide das regiões delimitadas nas Figuras 3.1 e 3.2. Esse tipo de gráfico pode ser empregado para identificar o componente que influencia mais a resposta. A amplitude horizontal indica a faixa de variação da proporção dos componentes, nos limites indicados no delineamento do experimento, partindo da mistura de referência para $+50 \%$ da faixa de variação e para $-50 \%$ desta faixa. A amplitude vertical indica a intensidade do efeito da variação da proporção do componente na mistura sobre a propriedade. Uma maneira mais rápida de analisar os efeitos é ver a porcentagem de cada 
componente aumentando da direita para a esquerda, dentro da sua respectiva faixa de variação.

Para interpretação do gráfico de efeito de componentes é importante ressaltar que:

- os componentes são interpretados em relação à mistura de referência;

- os componentes que apresentarem curvas com maior inclinação são os que apresentam maior efeito na resposta;

- os componentes que apresentam faixas amplas de ocorrência (limite superior -limite inferior) apresentarão curvas mais extensas, porém os que apresentarem faixas mais restritas apresentarão curvas mais curtas;

- o efeito total de um componente depende da sua faixa de ocorrência e da inclinação da curva correspondente;

- os componentes que apresentam curvas horizontais não causam nenhum efeito sobre a resposta;

- os componentes com curvas semelhantes causam efeitos semelhantes sobre a resposta.

É importante destacar que os modelos apresentados são limitados ao tipo de ligante asfáltico, de borracha moída e de resíduo de óleo de xisto empregados, assim como às condições experimentais adotadas neste estudo.

\subsection{Análise estatística das propriedades das misturas asfálticas não condicionadas}

Esta subseção tem por finalidade apresentar os resultados referentes à análise estatística dos dados obtidos no monitoramento das propriedades mecânicas das misturas. Serão apresentados os gráficos de efeito de componentes e de superfície de resposta juntamente com os modelos de regressão. Cabe ressaltar que, devido à quantidade de gráficos realizados para todos os cinco teores, optou-se por apresentar, nesta seção, apenas os referentes ao teor de ligante asfáltico de 5,5\%, sendo que, a maioria das misturas apresentou, neste teor, volume de vazios próximos a $4 \%$. 


\subsubsection{Superfície de Resposta e Efeito de componentes}

\subsubsection{Parâmetros volumétricos, estabilidade e fluência}

A Figura 4.21 mostra os gráficos de superfície de resposta e efeito de componentes para a densidade aparente.

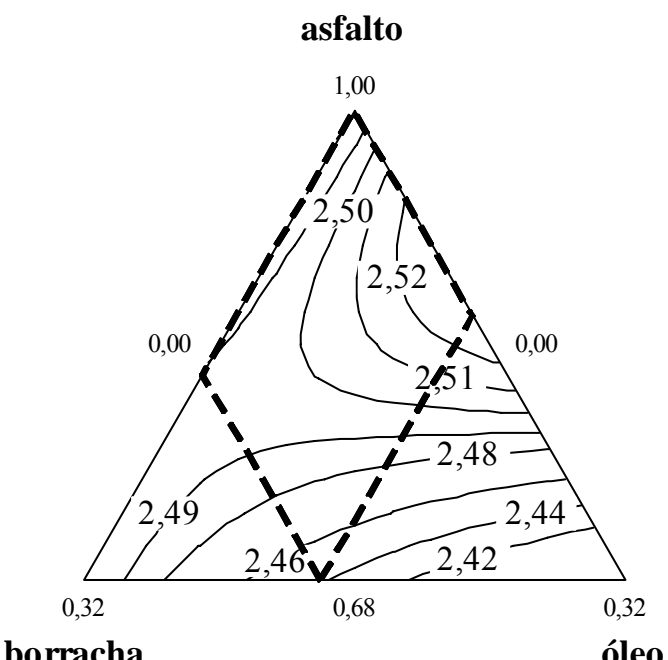

(a)

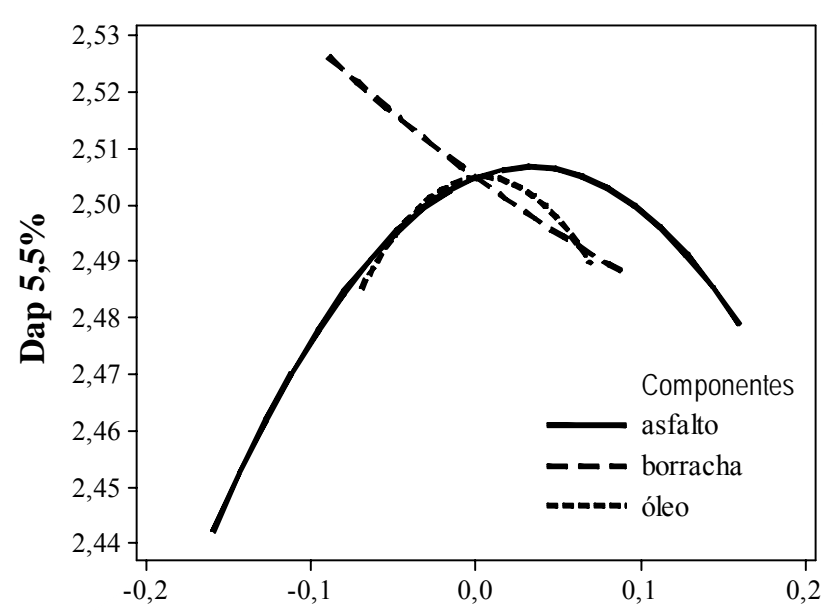

desvio da mistura de referência em proporção

(b)

Figura 4.21: Superfície de resposta (a) e efeitos dos componentes (b) para densidade aparente

Pode-se observar da Figura 21 (a) que os valores mais altos de densidades são obtidos quando empregados ligantes asfálticos com teores baixos de borracha e intermediários a altos de óleo. Quanto ao efeito dos componentes nota-se, através da Figura 21 (b), que o asfalto tem efeito parabólico sobre esse parâmetro, tendo seu ponto de máximo aproximadamente em $87 \%$. O efeito da borracha, por sua vez, reduz a densidade aparente de forma linear, e o óleo apresenta efeito parabólico com ponto de máximo em torno de $8 \%$. Para a condição particular em que estes gráficos são gerados, é possível obter aumento da densidade aparente aumentando a concentração de óleo na composição, até teores de $8 \%$. No caso do efeito da borracha, o aumento da porcentagem de borracha reduz a densidade aparente. 
Os gráficos referentes ao volume de vazios estão apresentados na Figura 4.20, a seguir.

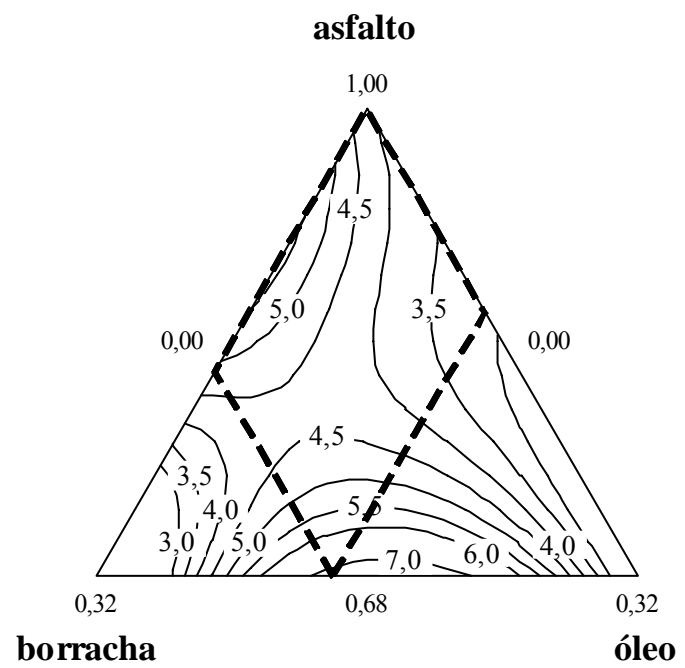

(a)

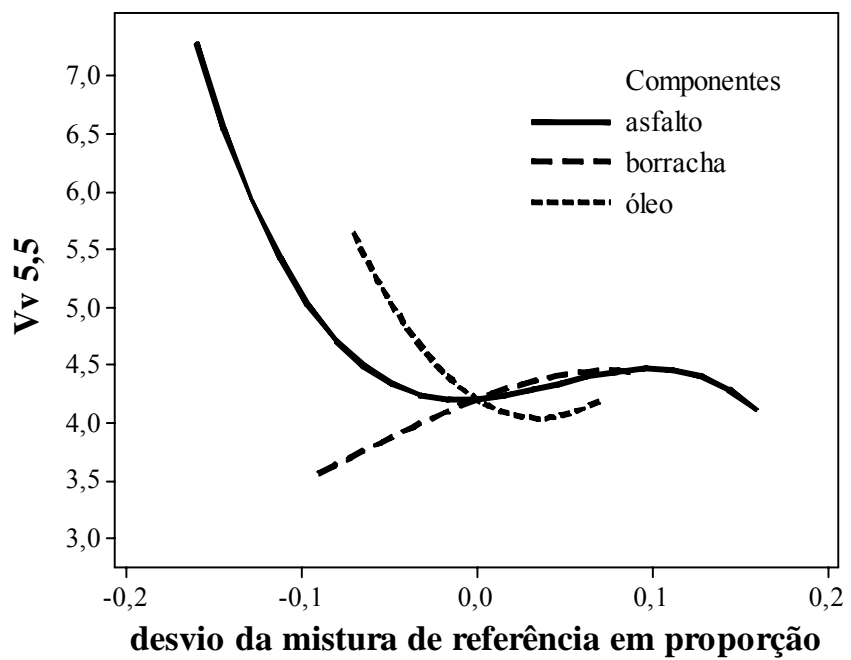

(b)

Figura 4.22: Superfície de resposta (a) e efeitos dos componentes (b) para o volume de vazios

A superfície de resposta, conforme mostra a Figura 4.22 (a), indica que as composições de dentro da região experimental com concentrações de valores baixos e intermediários de borracha e óleo proporcionam misturas asfálticas que atendem o requisito de volume de vazios (3\% a 5\%), da especificação DNIT 031/2006. Através da Figura 4.22 (b) nota-se que o asfalto reduz esse parâmetro dependendo da proporção utilizada. A borracha tende a aumentar o volume de vazios à medida que se adiciona o componente na mistura, enquanto o óleo tem efeito parabólico, apresentando ponto de mínimo em torno de $11 \%$.

As análises referentes ao VAM estão baseadas nos gráficos mostrados na Figura 4.23. A Figura 4.23(a) indica que todas as composições de dentro da região experimental propiciam misturas asfálticas que atendem o requisito de VAM mínimo de 16\%, da especificação de serviço DNIT 031/2006. O gráfico de efeito de componente, Figura 4.23 (b), mostra que o asfalto proporciona efeito parabólico, apresentando ponto de mínimo em aproximadamente $88 \%$, enquanto a borracha apresenta comportamento linear, proporcionando o aumento desse parâmetro e o óleo tem efeito parabólico, diminuindo o VAM para concentrações entre 0 e $7 \%$ e o aumentando a partir desta concentração. 


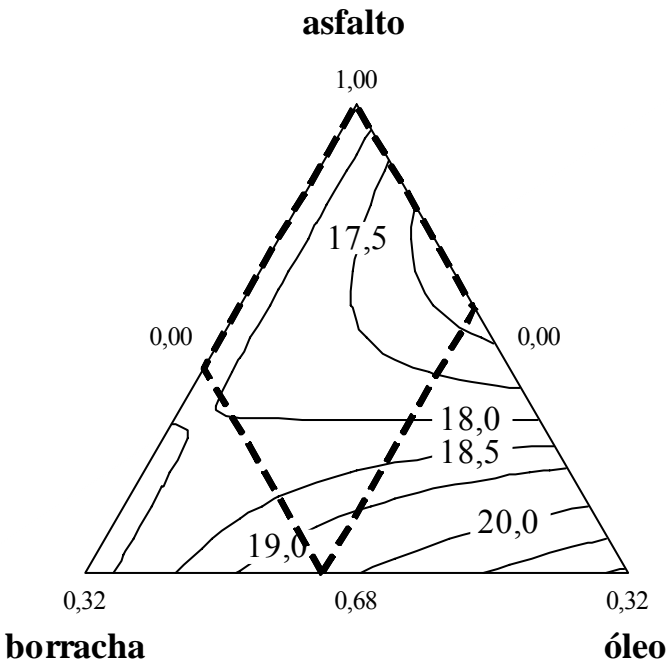

(a)

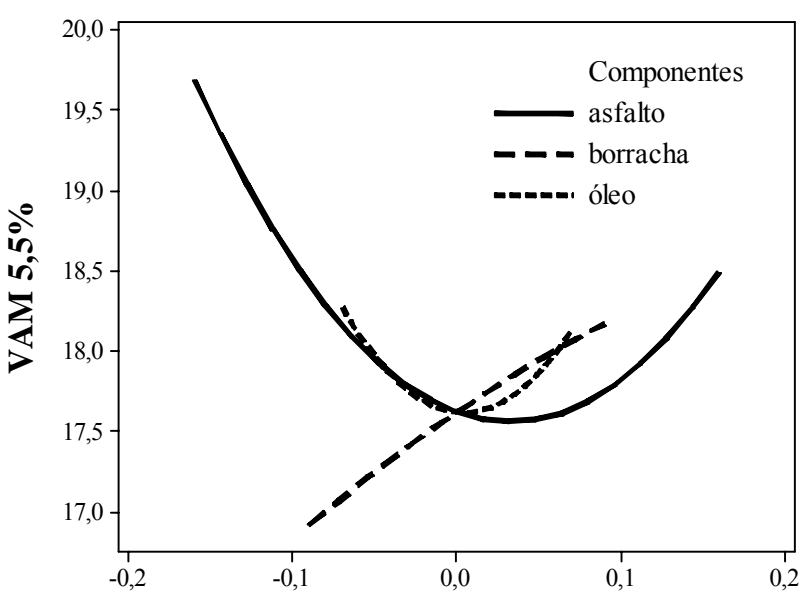

desvio da mistura de referência em proporção

(b)

Figura 4.23: Superfície de resposta (a) e efeitos dos componentes (b) para o VAM

A Figura 4.24 mostra os gráficos de superfície de resposta e efeito de componentes para a relação betume-vazios no teor de 5,5\% de ligante.

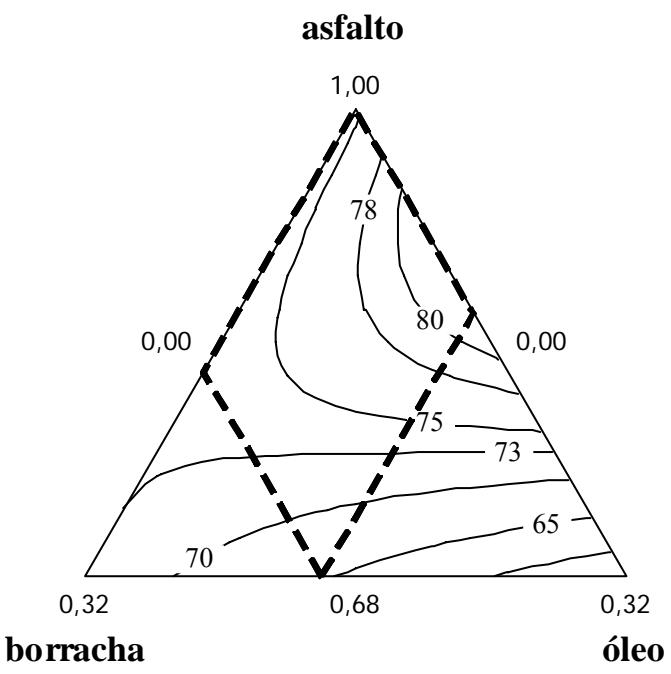

(a)

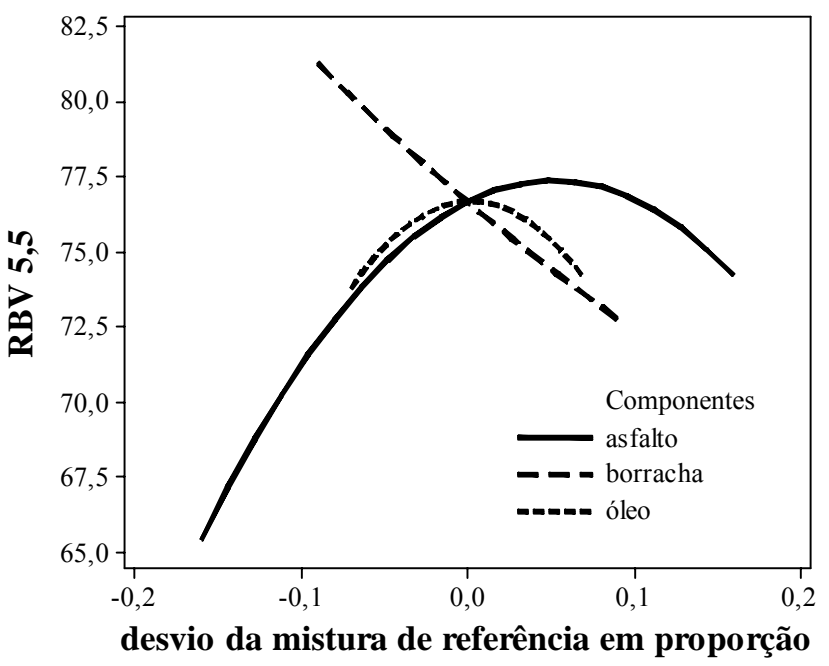

(b)

Figura 4.24: Superfície de resposta (a) e efeitos dos componentes (b) para RBV

Conforme ilustra a Figura 4.24 (a), a superfície de resposta mostra que todas as composições de misturas, exceto as com altas concentrações dos dois componentes, produzem misturas que atendem o requisito de relação betume-vazios (75 a 82\%), DNIT 031/2006. Quanto ao efeito dos componentes, pode-se observar através da Figura 4.24 (b) que o asfalto tem efeito parabólico, apresentando ponto de máximo em torno de $90 \%$. A borracha tende a reduzir a 
relação betume-vazios, enquanto que o óleo produz efeito parabólico com ponto de máximo aproximadamente em $7 \%$.

Apesar de não apresentarem bons ajustes, em parte por causa do número reduzido de amostras, foi realizada a análise dos gráficos referente aos valores de fluência, conforme mostra a Figura 4.25 .

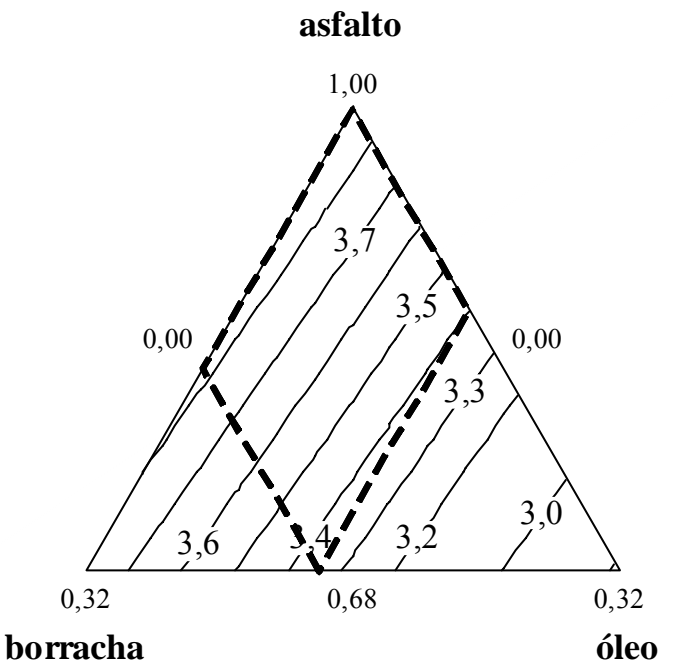

(a)

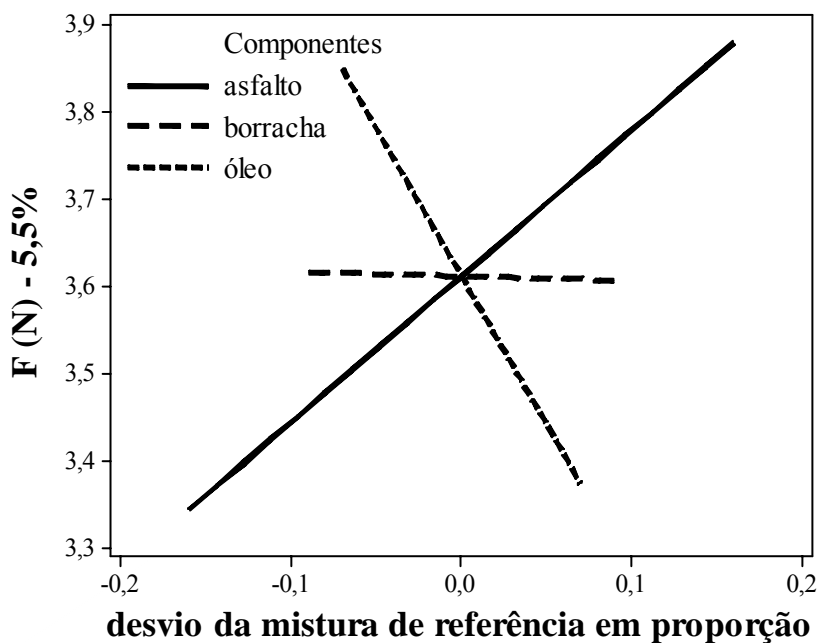

(b)

Figura 4.25: Superfície de resposta (a) e efeitos dos componentes (b) para fluência

Nota-se da Figura 4.25 (a) que todas as composições apresentam misturas que atendem o requisito da especificação do ES-P 28/05 DER/PR para asfalto-borracha, com intervalo de 2,0 a 4,1 $\mathrm{mm}$. Observa-se também que a borracha proporciona um efeito pouco efetivo sobre a fluência, enquanto o efeito do óleo é mais intenso. Quanto ao efeito de cada componente, a Figura 4.25 (b) mostra que todos apresentam efeito linear, no entanto, asfalto e óleo apresentam comportamento contrário, aumentando e diminuindo a fluência, respectivamente. Contudo, a borracha não apresentou um efeito significativo.

Os resultados em relação à estabilidade das misturas asfálticas estão apresentados nos gráficos da Figura 4.26. 


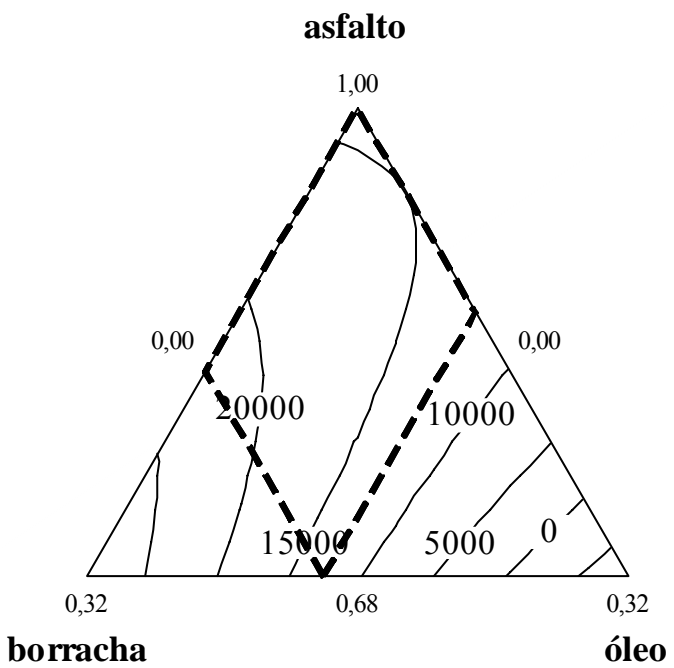

(a)

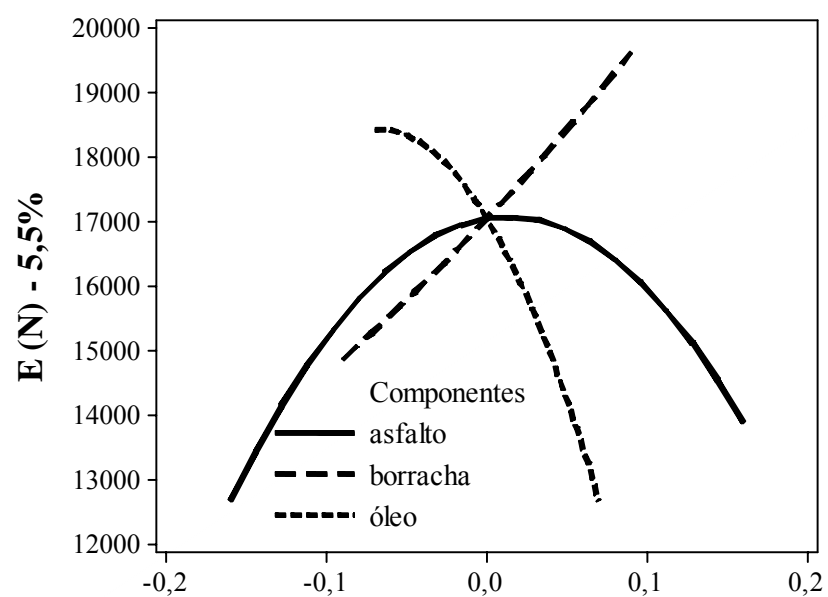

desvio da mistura de referência em proporção

(b)

Figura 4.26: Superfície de resposta (a) e efeitos dos componentes (b) para estabilidade

A superfície de resposta, conforme a Figura 4.26 (a), mostra que todas as composição internas à região experimental atendem o requisito da especificação DNIT 031/2006 para a estabilidade Marshall (estabilidade mínima de 5,0 kN). Misturas com proporções altas de óleo e independente de borracha apresentam os menores valores de estabilidade. O gráfico 4.26 (b) aponta o efeito dos componentes, no qual, o asfalto apresentou efeito parabólico com ponto de máximo em torno de $85 \%$. A borracha e o óleo mostram efeito linear, porém, distintos. A primeira aumenta e o segundo diminui a propriedade com o aumento da concentração dos componentes na mistura.

Os modelos de regressão para cada um dos parâmetros analisados estatisticamente estão apresentados na Tabela 4.5 .

Tabela 4.5: Modelos de regressão referente às propriedades monitoradas

\begin{tabular}{l|l|c|c}
\hline \multicolumn{1}{c|}{ propriedade } & \multicolumn{1}{|c|}{ Modelo de regressão } & $\mathrm{R}^{2}(\%)$ & $\mathrm{n}$ \\
\hline $\mathrm{D}_{\mathrm{ap}} 5,5 \%$ & $=2,48 \mathrm{x}_{1}+2,54 \mathrm{x}_{2}-0,57 \mathrm{x}_{3}+3,97 \mathrm{x}_{1} \mathrm{x}_{3}$ & 71,66 & 54 \\
\hline $\mathrm{V}_{\mathrm{V}} 5,5 \%(\%)$ & $=4 \mathrm{x}_{1}-105 \mathrm{x}_{2}-3 \mathrm{x}_{3}+138 \mathrm{x}_{1} \mathrm{x}_{2}+1465 \mathrm{x}_{2} \mathrm{x}_{3}-1753 \mathrm{x}_{1} \mathrm{x}_{2} \mathrm{x}_{3}$ & 89,73 & 55 \\
\hline VAM 5,5\%(\%) & $=18,5 \mathrm{x}_{1}+16,2 \mathrm{x}_{2}+119,4 \mathrm{x}_{3}-131,5 \mathrm{x}_{1} \mathrm{x}_{3}$ & 71,57 & 54 \\
\hline RBV 5,5\%(\%) & $=74,2 \mathrm{x}_{1}+69,8 \mathrm{x}_{2}-399,3 \mathrm{x}_{3}+759,9 \mathrm{x}_{1} \mathrm{x}_{3}+612,2 \mathrm{x}_{1} \mathrm{x}_{3}$ & 78,35 & 54 \\
\hline F 5,5\% $(\mathrm{mm})$ & $=3,88 \mathrm{x}_{1}+3,56 \mathrm{x}_{2}+0,45 \mathrm{x}_{3}$ & 39,22 & 16 \\
\hline E 5,5\% $(\mathrm{kN})$ & $=13,88 \mathrm{x}_{1}+61,06 \mathrm{x}_{2}-285,458 \mathrm{x}_{3}+338,167 \mathrm{x}_{1} \mathrm{x}_{3}$ & 27,38 & 16 \\
\hline
\end{tabular}

$\mathrm{x}_{1}$ : porcentagem de CAP; $\mathrm{x}_{2}$ : porcentagem de borracha; $\mathrm{x}_{3}$ : porcentagem de óleo 


\subsubsection{Módulo de Resiliência não-condicionado}

A análise da variação do módulo de resiliência também é realizada com o auxílio dos gráficos de superfície de resposta e de efeito de componentes, como mostra a Figura 4.27, para os módulos totais calculados pelo método NCHRP, na temperatura de $25^{\circ} \mathrm{C}$.

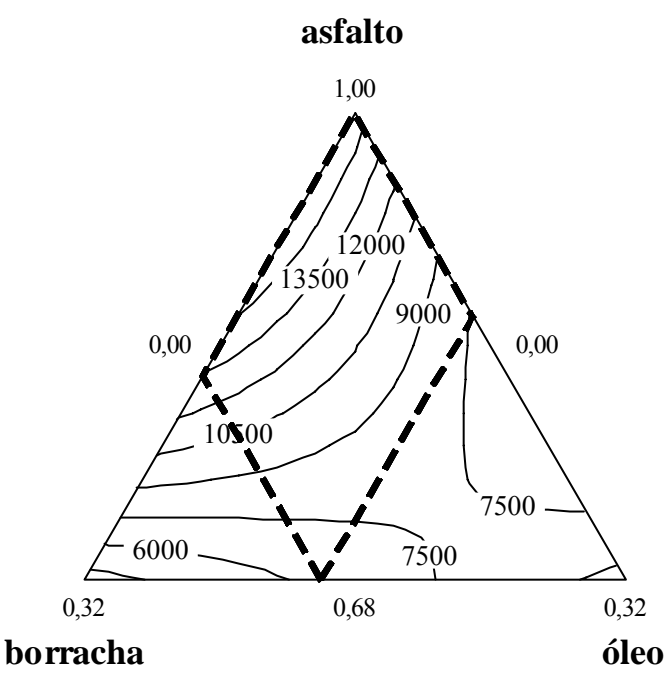

(a)

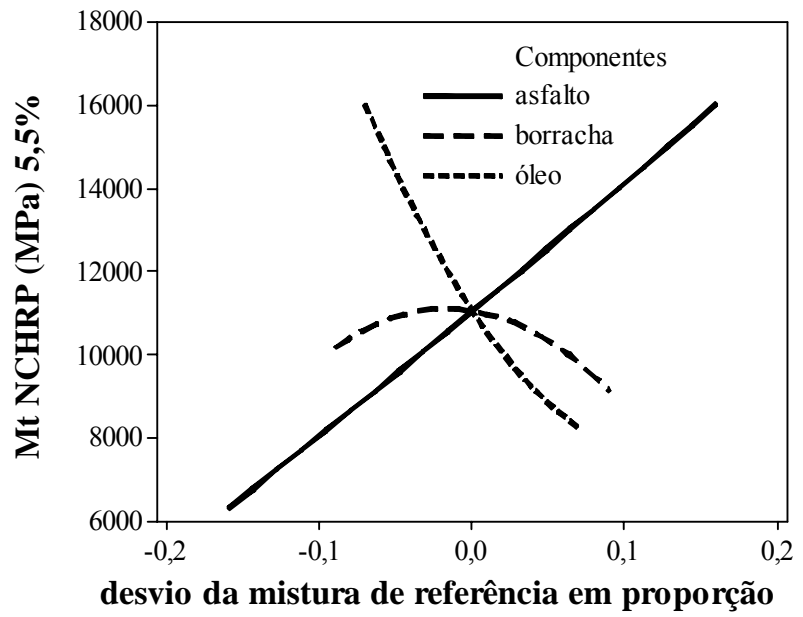

(b)

Figura 4.27: Superfície de resposta (a) e efeitos dos componentes (b) para MRt NCHRP

A Figura 4.27 (a) indica que os valores mais altos de módulo são obtidos para concentrações baixas a intermediárias de borracha e baixas de óleo (parte superior da região experimental), enquanto os valores baixos de módulos estão localizados na região que figuram misturas com teores altos de borracha e de óleo. Observa-se também que para pequenas concentrações de borracha não ocorre mudanças significativas nos valores dos módulos.

Pode-se perceber da Figura 4.27 (b) que o óleo propicia efeito contrário ao do asfalto, diminuindo de forma aproximadamente linear essa propriedade. A borracha apresenta um comportamento parabólico, com ponto de máximo em torno de $8 \%$. Cabe ressaltar que o comportamento dos componentes sobre o módulo de resiliência instantâneo é o mesmo, porém os valores são maiores. 


\subsubsection{Resistência à tração não-condicionada}

A Figura 4.28 apresenta os gráficos para a resistência à tração não condicionada. A Figura 4.28 (a) mostra a superfície de resposta para a resistência à tração sem condicionamento. Segundo a especificação do DNIT 031/2006, o valor para RT deve ser no mínimo de 0,65 $\mathrm{MPa}$, sendo assim, pode-se observar que todas as composições dentro da região experimental atendem esse requisito, pois apresentam valores superiores ao estabelecido pela especificação. O gráfico que representa o efeito dos componentes é apresentado na Figura 4.28 (b), onde observa-se que o asfalto tende a aumentar a resistência à tração, enquanto a borracha e o óleo proporcionam uma diminuição nessa propriedade, sendo que, o efeito do óleo é mais intenso que o da borracha na redução da resistência à tração.

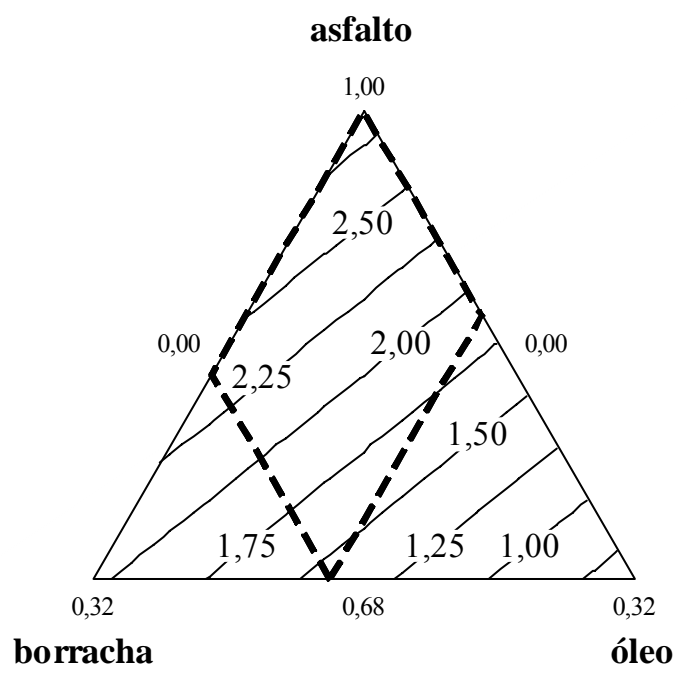

(a)

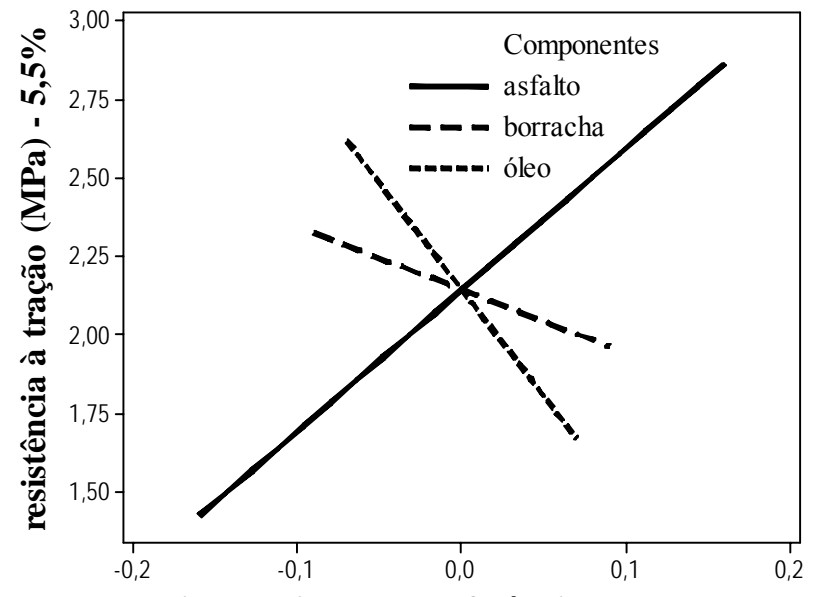

desvio da mistura de referência em proporção

(b)

Figura 4.28: Superfície de resposta (a) e efeitos dos componentes (b) para RT

\subsubsection{MRt/RT não condicionado}

Os gráficos de superfície de resposta e efeito de componentes referentes à relação do módulo de resiliência e resistência à tração são representados na Figura 4.29 (a) e (b), respectivamente. 


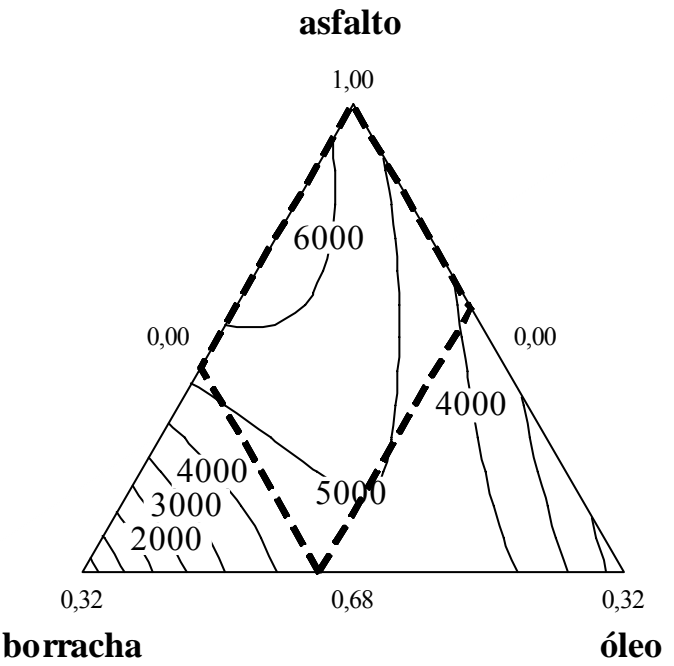

(a)

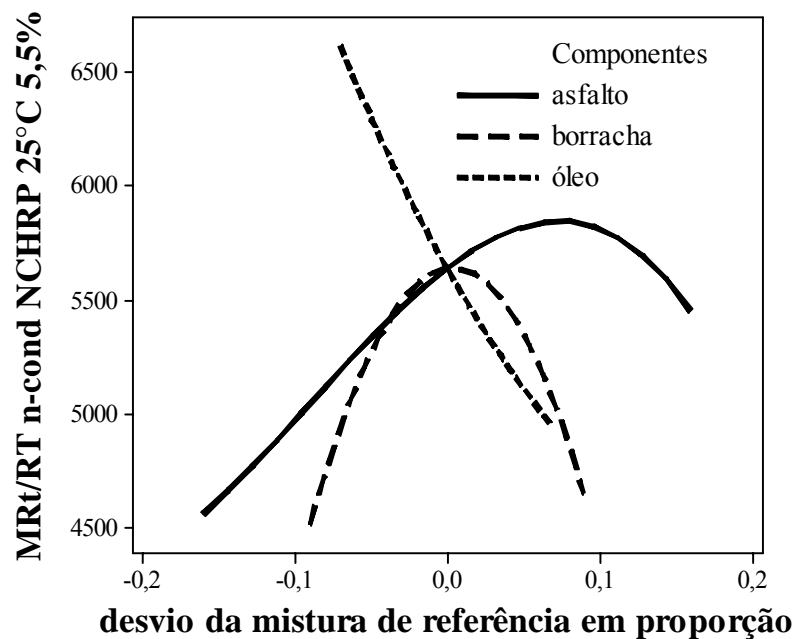

(b)

Figura 4.29: Superfície de resposta (a) e efeitos dos componentes (b) para MRt/RT

A literatura indica que misturas asfálticas compostas com ligantes não-modificados apresentam boas propriedades mecânicas quando possuem valores próximos de 3000 para a relação MRt/RT (Pinheiro et al, 2003), porém, observa-se que os valores das misturas de dentro da região experimental apresentam valores superiores a 3000. Em relação ao efeito dos componentes é possível notar, através da Figura 4.29 (b), que o asfalto apresenta um efeito parabólico tendo ponto de máximo em torno de 93\%. A tendência do óleo é de reduzir linearmente a relação MRt/RT, enquanto o efeito da proporção de borracha é parabólico, com ponto de máximo em torno de $9 \%$.

\subsubsection{Recuperação retardada}

A Figura 4.30 mostra os gráficos de superfície de resposta (a) e efeito de componentes (b) para o parâmetro recuperação retardada das misturas estudadas. 


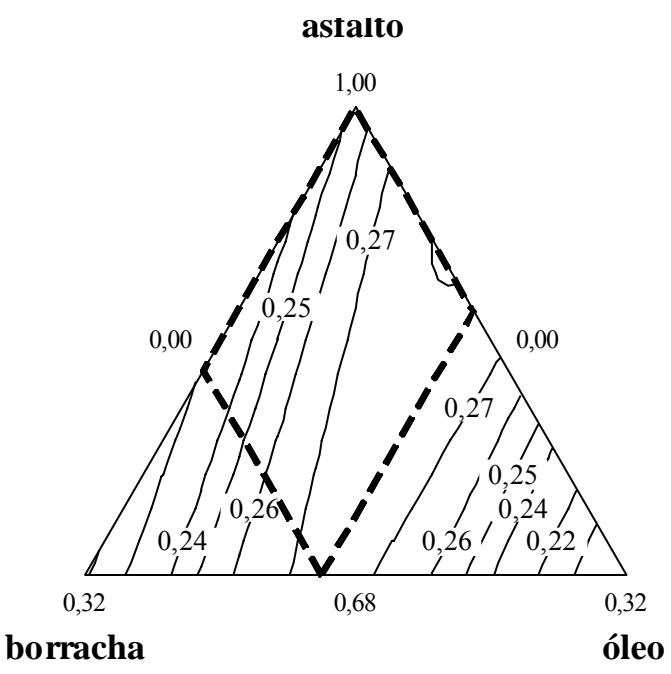

(a)

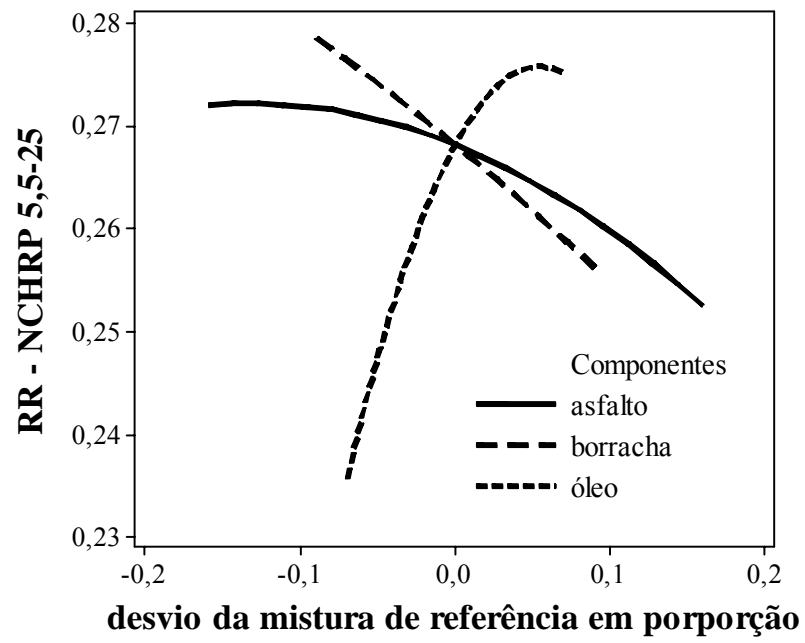

(b)

Figura 4.30: Superfície de resposta (a) e efeitos dos componentes (b) para RR

Pode-se observar da Figura 4.30 (a) que os maiores valores de recuperação retardada estão localizadas na região em que figuram misturas com quaisquer concentrações de borracha e concentrações baixas de óleo, enquanto os menores valores se encontram na combinação de qualquer quantidade de borracha e altas concentrações de óleo. O gráfico de efeito dos componentes 4.30 (b) mostra que o aumento da concentração de asfalto tende a diminuir a recuperação retardada. A tendência do óleo é aumentar esse parâmetro com efeito aproximadamente linear e pequeno nos teores altos, enquanto a borracha proporciona uma diminuição.

Os modelos de regressão referentes às propriedades mecânicas das misturas estão apresentados na Tabela 4.6.

Tabela 4.6: Modelos de regressão referente às propriedades monitoradas

\begin{tabular}{l|l|c|c}
\hline \multicolumn{1}{c|}{ propriedade } & \multicolumn{1}{|c|}{ modelo de regressão } & $\mathrm{R}^{2}(\%)$ & $\mathrm{n}$ \\
\hline $\mathrm{M}_{\mathrm{t}}$ NCHRP 5,5\% (MPa) & $=16029 \mathrm{x}_{1}-137346 \mathrm{x}_{2}+150763 \mathrm{x}_{3}+169688 \mathrm{x}_{1} \mathrm{x}_{2}-228335 \mathrm{x}_{1} \mathrm{x}_{3}$ & 91,5 & 55 \\
\hline RT 5,5\% $(\mathrm{MPa})$ & $=2,865 \mathrm{x}_{1}-0,311 \mathrm{x}_{2}-4,153 \mathrm{x}_{3}$ & 82,2 & 16 \\
\hline MRt/RT 5,5\% & $=5.450 \mathrm{x}_{1}-120.991 \mathrm{x}_{2}-6.732 \mathrm{x}_{3}-153.242 \mathrm{x}_{1} \mathrm{x}_{2}+442.419 \mathrm{x}_{1} \mathrm{x}_{3}-369.475 \mathrm{x}_{1} \mathrm{x}_{2} \mathrm{x}_{3}$ & 71,6 & 54 \\
\hline RR 5,5\% & $=0,253 \mathrm{x}_{1}+0,079 \mathrm{x}_{2}-1,709 \mathrm{x}_{3}+2,491 \mathrm{x}_{1} \mathrm{x}_{3}+3,497 \mathrm{x}_{2} \mathrm{x}_{3}$ & 77,6 & 56 \\
\hline
\end{tabular}

$\mathrm{x}_{1}$ : porcentagem de CAP; $\mathrm{x}_{2}$ : porcentagem de borracha; $\mathrm{x}_{3}$ : porcentagem de óleo 


\subsection{Análise estatística das propriedades das misturas asfálticas condicionadas}

Em função da não saturação de uma parte dos corpos-de-prova nos teores de ligantes asfáltico de 5,5, 6,0 e 6,5\%, como já mencionado no capítulo anterior, as propriedades e relações dependentes das amostras condicionadas não puderam ser modeladas. Portanto, as propriedades referentes à umidade induzida são apresentadas no teor de 5,0\%.

\subsubsection{Módulo de Resiliência condicionado}

As Figuras 4.31 (a) e (b) mostram as superfícies de repostas e efeito de componentes para o módulo de resiliência total para o teor de 5,0\%. No gráfico de superfície de resposta, Figura 4.31 (a) observa-se que a variação do módulo, alterando as proporções dos componentes, é linear. Módulos mais baixos são encontrados na região em que figuram composições com proporções altas tanto de borracha quanto de óleo; no entanto, os módulos mais altos são observados na região em que figuram composições com proporções baixas tanto de borracha quanto de óleo.

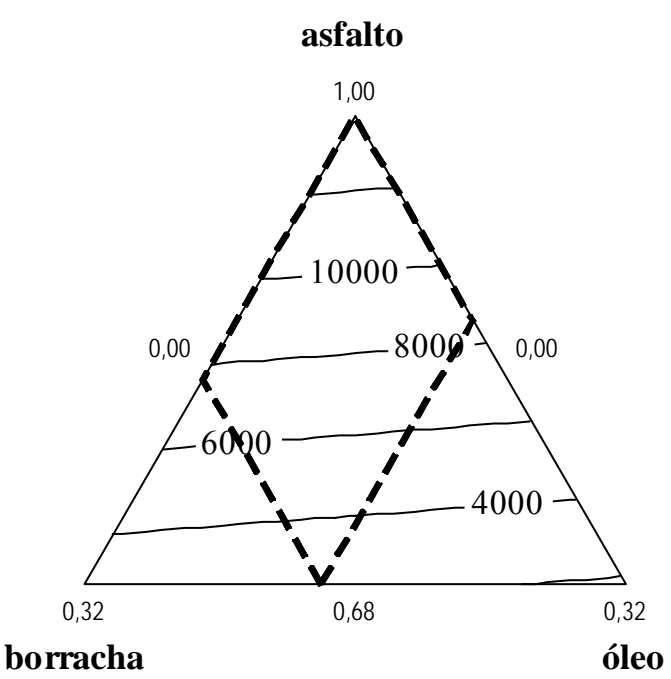

(a)

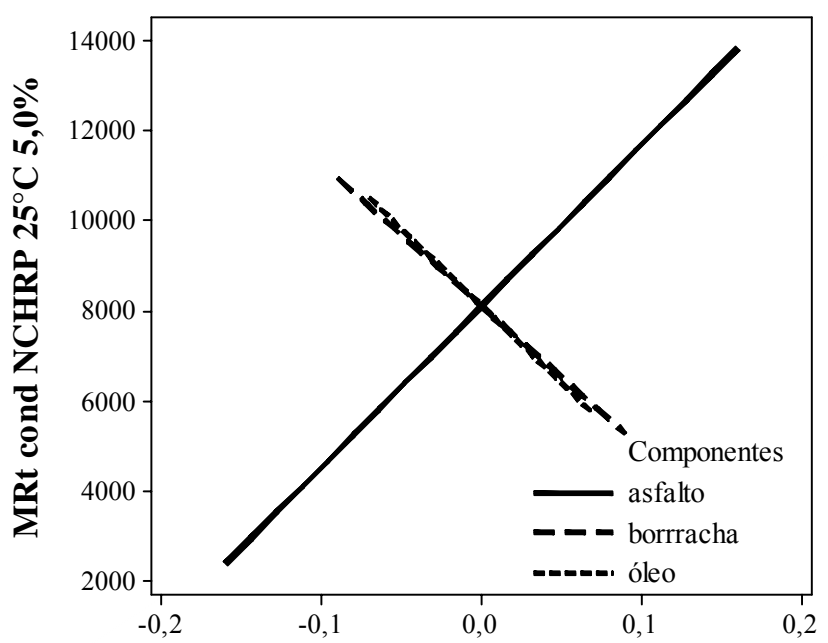

desvio na mistura de referência em proporção

(b)

Figura 4.31: Superfície de resposta (a) e efeitos dos componentes (b) para MRt NCHRP condicionado 
Quanto ao efeito de componentes, a Figura 4.31 (b) mostra que a tendência do asfalto é aumentar o valor do módulo pós condicionamento, enquanto a borracha e o óleo possuem efeitos similares, proporcionando redução linear do módulo e com mesma intensidade.

\subsubsection{Resistência à tração condicionada}

Os gráficos de superfície de resposta e efeito de componentes estão apresentados na Figura 4.32 (a) e (b). Do gráfico de superfície de resposta nota-se que a variação da resistência à tração é linear. Resistências mais baixas são encontradas na região em que figuram composições com proporções altas tanto de borracha quanto de óleo, porém as altas resistências são observadas na região com composição com proporções baixas tanto de borracha quanto de óleo. Cabe ressaltar que todas as composições que estão dentro da região experimental atendem o requisito estabelecido pela especificação DNIT 031/2006 de apresentarem valores de resistência à tração acima de $0,65 \mathrm{MPa}$. O gráfico de efeito dos componentes, Figura 4.32 (b), mostra que a borracha e o óleo têm efeitos similares, reduzindo a resistência à tração linearmente. Nota-se que o efeito da borracha é ligeiramente maior que a do óleo.

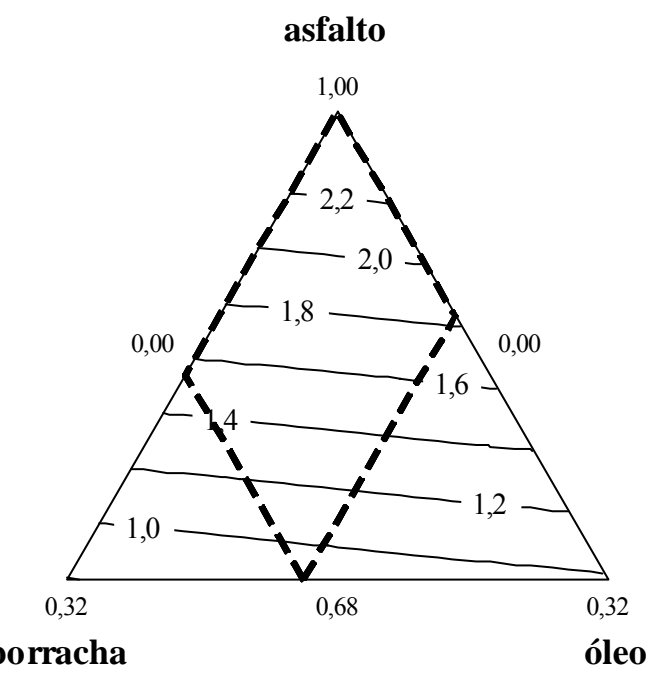

(a)

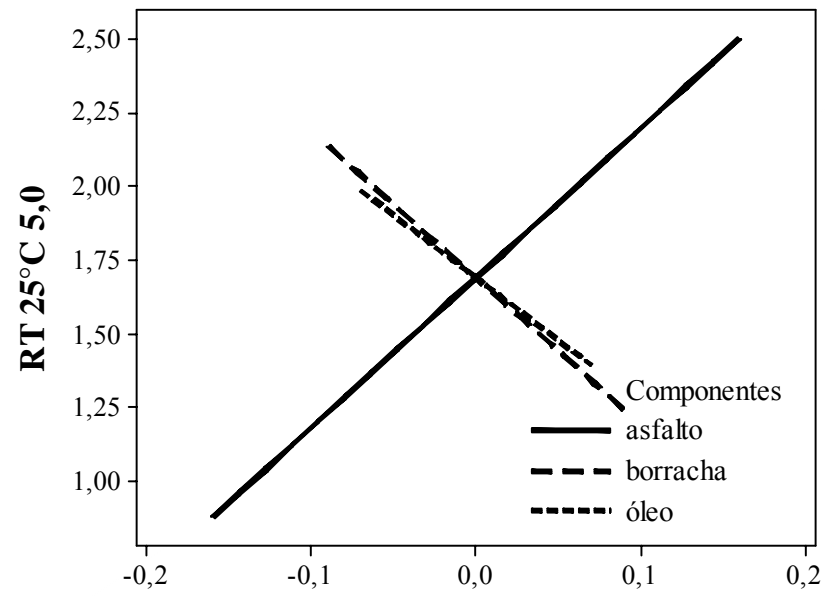

desvio na mistura de referência em proporção

(b)

Figura 4.32: Superfície de resposta (a) e efeitos dos componentes (b) para RT condicionada 


\subsubsection{MRt/RT condicionada}

A Figura 4.33 apresenta os gráficos de superfície de resposta e efeito de componentes para a relação MR/RT após o condicionamento.

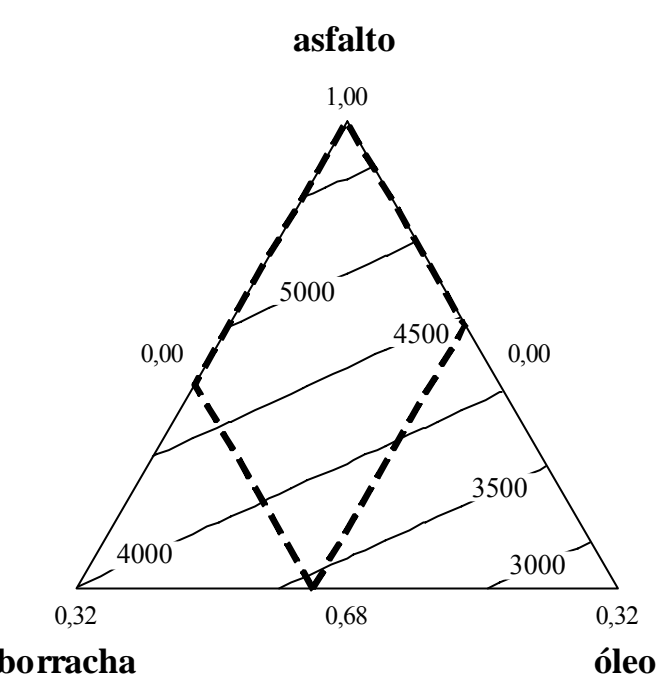

(a)

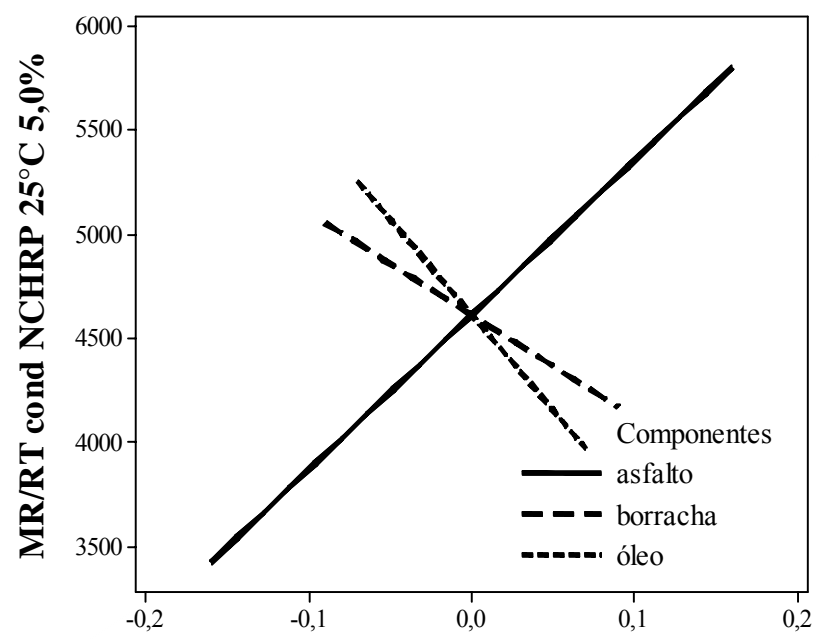

desvio na mistura de referência em proporção

(b)

Figura 4.33: Superfície de resposta (a) e efeitos dos componentes (b) para MRt/RT condicionada

Observa-se que as misturas contidas na região experimental apresentam valores da relação MRt/RT superiores a 3000, sendo que os valores mais próximos a 3000 estão localizados na região em que figuram composições com concentrações baixas de borracha e de óleo. Quanto ao efeito dos componentes, nota-se que a tendência tanto da borracha quanto a do óleo é de reduzir a relação MRt/RT, sendo o efeito do óleo mais intenso do que o da borracha.

\subsubsection{Recuperação retardada condicionada}

Os gráficos referentes à recuperação retardada após condicionamento dos corpos-de-prova são apresentados na Figura 4.34 (a) e (b). O gráfico da superfície de resposta mostra que os menores valores de recuperação retardada estão na região com concentrações baixas e intermediárias tanto de borracha quanto de óleo. Nota-se também que não ocorre muita variação no valor da RR na região experimental. Na Figura 4.34 (b) observa-se que a tendência do óleo é aumentar o valor da recuperação retardada, enquanto a borracha apresenta 
um comportamento parabólico com aumento dessa relação entre 0 e $8 \%$ e redução entre 8 e $18 \%$ de concentração de borracha.

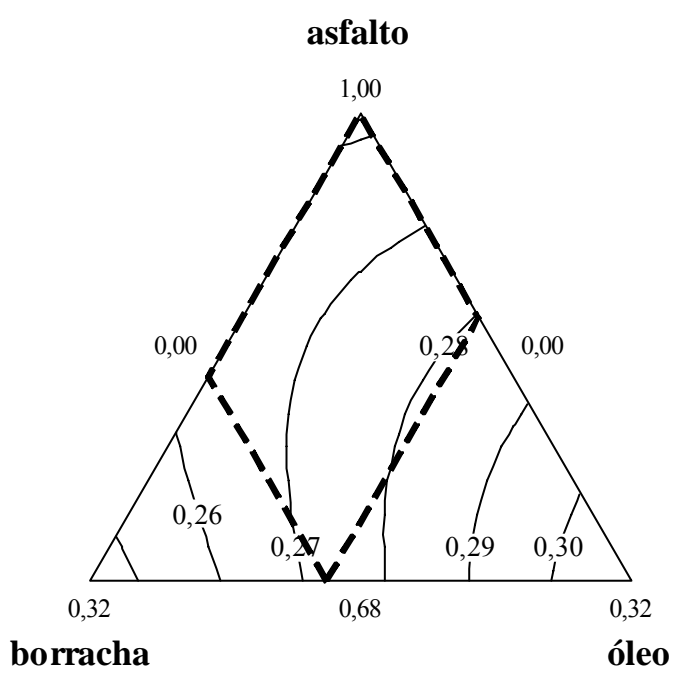

(a)

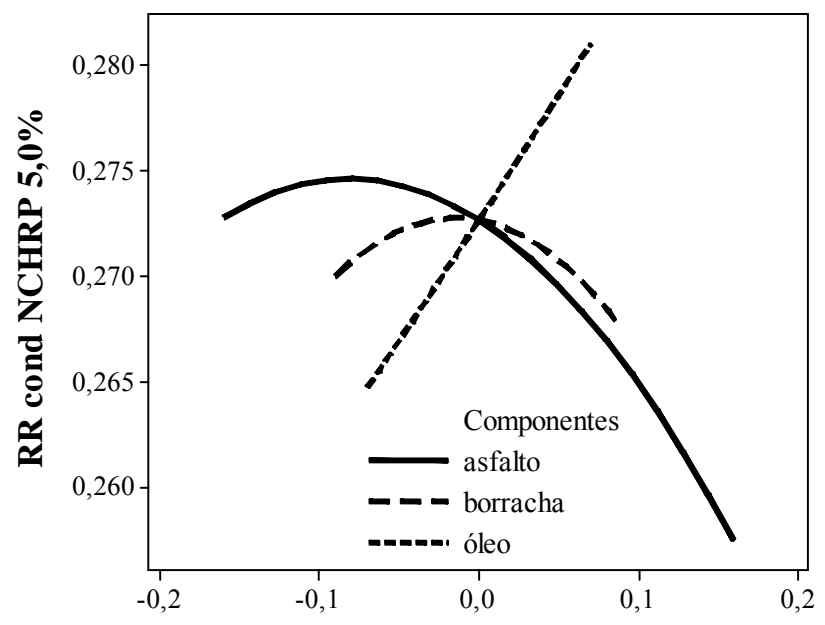

desvio na mistura de referência em proporção

(b)

Figura 4.34: Superfície de resposta (a) e efeitos dos componentes (b) para RR condicionada

\subsubsection{Relação RMR}

Os gráficos referentes à superfície de resposta e efeito dos componentes da relação RMR estão apresentados na Figura 4.35.

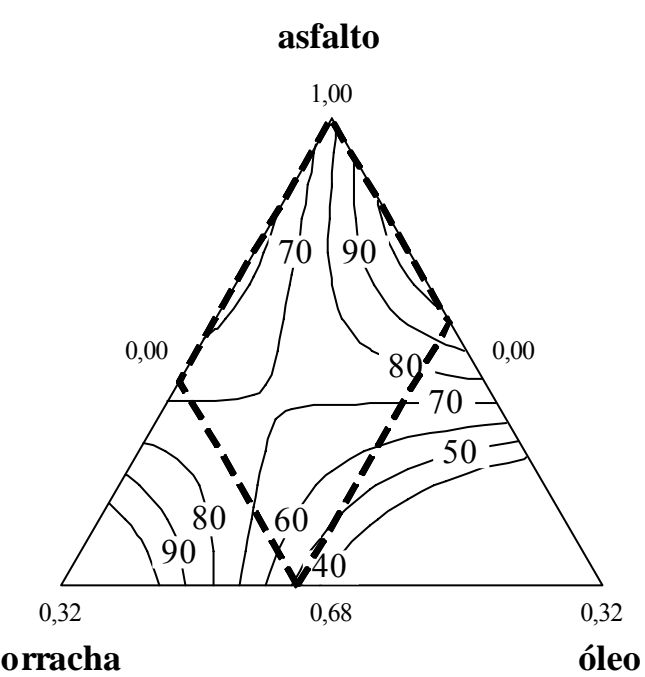

(a)

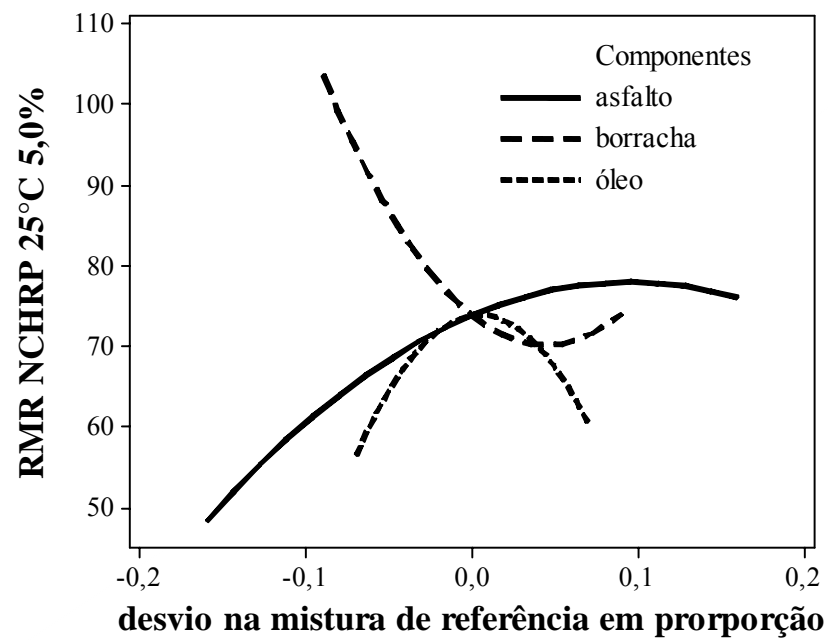

(b)

Figura 4.35: Superfície de resposta (a) e efeitos dos componentes (b) para relação RMR 
A superfície de resposta para esta relação indica que as composições que proporcionam maiores valores de RMR são caracterizadas por concentrações baixas de borracha e intermediárias de óleo. Observa-se através do gráfico de efeito de componentes que a borracha reduz esta relação para concentração entre 0 e $13 \%$ e a aumenta para teores entre 13 e $18 \%$. O aumento da concentração de borracha prejudica a resistência ao efeito da água em temos de variação de módulo de resiliência. O óleo também apresenta efeito parabólico, porém contrário ao da borracha, com ponto de máximo em torno de $7 \%$. $\mathrm{O}$ aumento da concentração de óleo aumenta a resistência ao efeito da água, em termos da retenção do módulo de resiliência.

\subsubsection{Relação RRT}

A Figura 4.36 (a) apresenta a superfície de resposta da relação RRT. Nela percebe-se que as composições que proporcionam maiores valores da relação RRT estão localizadas na região com baixas concentrações de borracha e intermediárias a altas de óleo. Considerando o limite mínimo da RRT de 70\%, seriam admissíveis as misturas com composição contendo quaisquer proporções de borracha, para concentrações intermediárias a baixas de óleo, ou concentrações de intermediárias e altas de borracha e óleo.

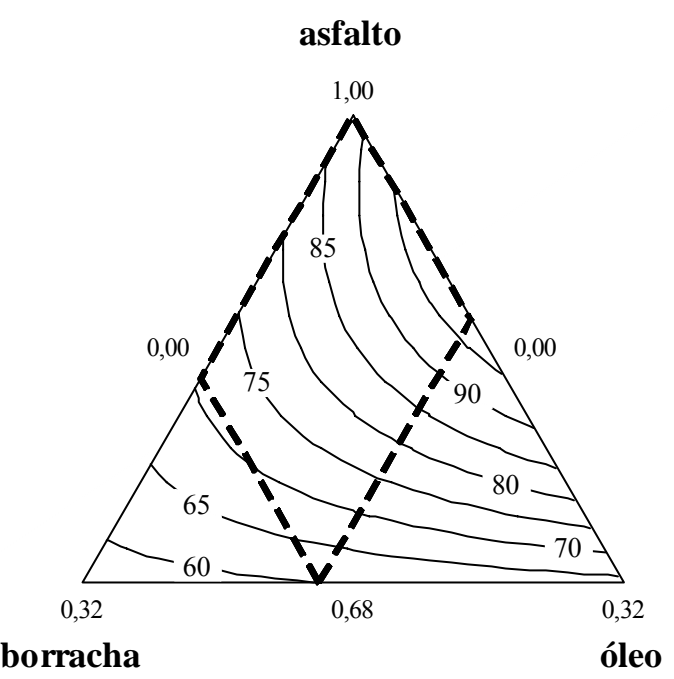

(a)

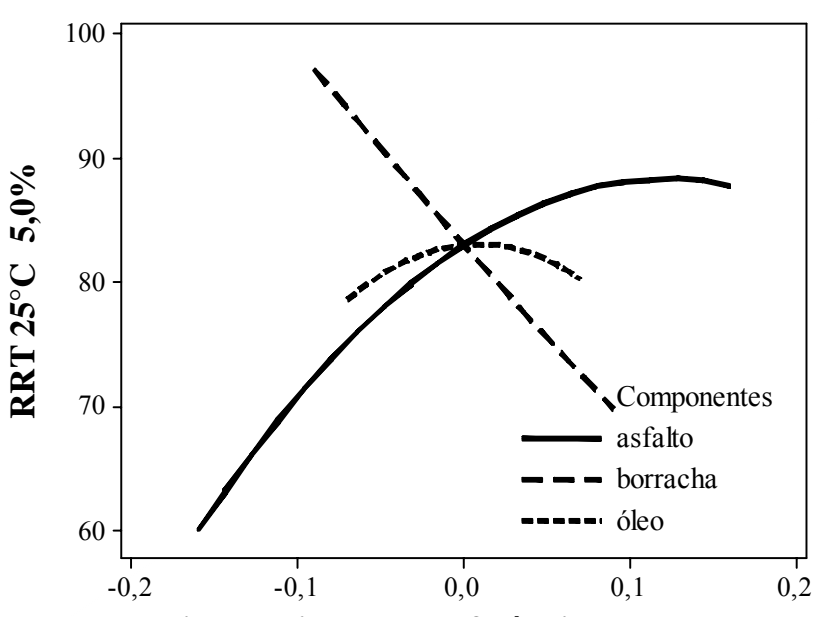

desvio na mistura de referência em proporção

(b)

Figura 4.36: Superfície de resposta (a) e efeitos dos componentes (b) para relação RMR 
A Figura 4.36(b) apresenta o efeito dos componentes sobre esta relação. Observa-se que a tendência da borracha é reduzir essa relação, enquanto o óleo apresenta um efeito parabólico com ponto de máximo em torno de $8 \%$, ou seja, o aumento da concentração de óleo de 0 a $8 \%$ proporciona um aumento da relação e, para concentrações de 8 a 14\% a reduz.

Os modelos de regressão das propriedades das misturas condicionadas estão apresentados na tabela a seguir.

Tabela 4.7 Modelos de regressão referentes às propriedades das misturas condicionadas

\begin{tabular}{l|l|c|c}
\hline \multicolumn{1}{c|}{ propriedade } & \multicolumn{1}{|c|}{ modelo de regressão } & $\mathrm{R}^{2}(\%)$ & $\mathrm{n}$ \\
\hline $\mathrm{M}_{\mathrm{t}}$ NCHRP 5,0\% (MPa) & $=13.836 \mathrm{x}_{1}-20.564 \mathrm{x}_{2}-23.751 \mathrm{x}_{3}$ & 90,7 & 23 \\
\hline RT 5,0\% (MPa) & $=2,499 \mathrm{x}_{1}-2,822 \mathrm{x}_{2}-2,247 \mathrm{x}_{3}$ & 82,7 & 23 \\
\hline MRt/RT 5,0\% & $=5.802 \mathrm{x}_{1}+139 \mathrm{x}_{2}-3.921 \mathrm{x}_{3}$ & 78,9 & 23 \\
\hline RR 5,0\% & $=0,257 \mathrm{x}_{1}-0,141 \mathrm{x}_{2}+0,421 \mathrm{x}_{3}+0,524 \mathrm{x}_{1} \mathrm{x}_{2}$ & 62,0 & 23 \\
\hline RMR 5,0\% & $=76 \mathrm{x}_{1}+1,464 \mathrm{x}_{2}-2.614 \mathrm{x}_{3}-1.760 \mathrm{x}_{1} \mathrm{x}_{2}+3.304 \mathrm{x}_{1} \mathrm{x}_{3}$ & 85,7 & 23 \\
\hline RRT 5,0\% & $=87,8 \mathrm{x}_{1}-7,8 \mathrm{x}_{2}-542,9 \mathrm{x}_{3}+815,7 \mathrm{x}_{1} \mathrm{x}_{3}$ & 95,6 & 22 \\
\hline
\end{tabular}

$\mathrm{x}_{1}$ : porcentagem de CAP; $\mathrm{x}_{2}$ : porcentagem de borracha; $\mathrm{x}_{3}$ : porcentagem de óleo

\subsection{Comentários Finais}

Em suma, pode-se observar que o efeito da borracha é pouco efetivo na fluência, no entanto, ocorre aumento na estabilidade. A borracha tende a reduzir o módulo de resiliência, desde que sejam empregados teores de intermediários a altos. Nas misturas condicionadas observa-se a redução do módulo de resiliência com a adição de borracha. $\mathrm{Na}$ temperatura de $25^{\circ} \mathrm{C}$, nas misturas condicionadas e não-condicionadas, a adição de borracha também reduz a resistência à tração. Já a recuperação retardada, para concentrações até $8 \%$, reduz com adição da borracha.

Constatou-se que, a adição de óleo proporciona a redução da fluência e da estabilidade das misturas. Da mesma maneira, o efeito do óleo, nas misturas condicionadas e não condicionadas, é reduzir o módulo de resiliência, a resistência à tração, entretanto, a adição de óleo proporciona o aumento da recuperação retardada. 
Através dos gráficos de superfície de resposta, observa-se que, as misturas dentro da região experimental atendem as especificações do DNIT 031/2006 ES e do ES-P 28/05 DER/PR, com exceção de misturas com altas concentrações dos dois modificados. Sendo assim, percebe-se a possibilidade de se estabelecer proporções adequadas de óleo e borracha visando melhorar as características das misturas, e atender, ao mesmo tempo, as especificações vigentes. 


\section{Capítulo 5}

CONCLUSÕES

Este trabalho teve como objetivo analisar o efeito da borracha moída de pneu e do resíduo de óleo de xisto sobre algumas propriedades mecânicas em misturas asfálticas densas. O experimento englobou ensaios de laboratório com 8 misturas diferentes, a fim de coletar dados para a modelagem estatística de algumas propriedades mecânicas. Foram realizadas modelagens das propriedades mecânicas antes e após o ensaio de umidade induzida. Com base nos modelos de regressão, foram gerados gráficos de superfície de resposta e de efeito de componentes, empregados na avaliação dos efeitos principais e de interação entre os componentes.

\subsection{Parâmetros Marshall}

Em relação aos parâmetros Marshall, observou-se que a adição de óleo e de borracha nas misturas, de maneira geral, proporciona um aumento da densidade aparente. Quanto ao volume de vazios, nota-se um comportamento antagônico dos modificadores, sendo que o óleo propicia a sua redução, enquanto a adição de borracha tende a aumentá-lo. Cabe ressaltar que os maiores valores de volume de vazios são apresentados pelas misturas com altas concentrações de óleo e de borracha.

A adição tanto de óleo quanto de borracha proporciona uma redução nos vazios de agregado mineral (VAM), sendo que, os maiores valores são encontrados nas misturas com altas concentrações dos dois modificadores. Com respeito à relação betume-vazios (RBV), a adição do óleo e da borracha são antagônicos, ou seja, o óleo tende a aumentar esse parâmetro enquanto a borracha o diminui. Os menores valores desse parâmetro são apresentados pelas misturas com altas concentrações de óleo e borracha, ao passo que os maiores valores são verificados nas misturas com concentrações altas de óleo e intermediárias de borracha. 
Os dois modificadores apresentam efeitos antagônicos em relação à estabilidade das misturas. Observa-se uma redução da estabilidade com adição de óleo e um aumento com adição da borracha. Contudo, óleo e borracha apresentam mesmo efeito na fluência, reduzindo o valor dessa propriedade.

\subsection{Propriedades Mecânicas (misturas não condicionadas)}

Quanto ao valor do módulo de resiliência, pode-se dizer que a adição tanto de óleo quanto de borracha tende a diminuí-lo. Entretanto, o efeito do óleo é mais intenso do que o da borracha, sendo que misturas com adição de $14 \%$ de óleo apresentam redução dessa propriedade em até $75 \%$.

A adição dos dois modificadores proporciona a diminuição da resistência à tração das misturas asfálticas. Também no caso da resistência à tração, o efeito do óleo é mais intenso do que da borracha, pois misturas com adição de 14\% de óleo chegam a apresentar redução de $57 \%$ na RT, enquanto a maior redução encontrada nas misturas com adição de borracha é de $28 \%$.

De forma geral, o efeito do óleo e da borracha na relação MR/RT é antagônico. A adição de óleo tende a reduzir essa relação enquanto a borracha proporciona o seu aumento. Cabe ressaltar que as misturas com adição dos dois componentes apresentam redução na relação $\mathrm{MR} / \mathrm{RT}$.

O efeito do óleo e da borracha é antagônico quanto à recuperação retardada. Misturas com adição de óleo apresentam valores de RR menores que a mistura de referência, ao passo que nas com adição de borracha verifica-se maiores valores de RR. Para misturas com a combinação dos dois componentes observam-se maiores valores de RR em relação à mistura de referência. 


\subsection{Propriedades pós-condicionamento}

Depois de condicionadas, de forma geral, as misturas com adição tanto de óleo quanto de borracha apresentaram menores valores de módulo de resiliência, expressando perda de rigidez. Observa-se, de forma similar ao módulo, a redução da resistência à tração quando adicionados os modificados às misturas. Destaca-se que quando considerado o limite mínimo de RRT de 70\%, nota-se que as misturas com adição de óleo são menos suscetíveis ao condicionamento. Observa-se que o condicionamento provocou aumento na recuperação retardada de todas as misturas modificadas, exceto para as misturas com altas concentrações de óleo e de borracha.

\subsection{Conclusões obtidas da análise de superfícies de resposta}

As principais conclusões obtidas da análise de superfície de resposta, em relação ao óleo de xisto e da borracha moída de pneu, para as propriedades com limites estabelecidos pelas especificações do DNIT 31/2006 e ES-P 28/05 DER/PR estão comentadas a seguir:

Parâmetros volumétricos: volumes de vazios de 3 a 5\% são encontrados para todas as composições dentro da região experimental, exceto para misturas com altas concentrações de óleo e borracha, as quais apresentam valores superiores aos indicados pela especificação. Em relação ao volume de vazios do agregado mineral, o requisito mínimo de $16 \%$ é atendido por todas as misturas da região experimental. Quanto à relação betume-vazios, somente as misturas com altas concentrações de óleo e borracha não atenderam o limite de 70 a $82 \%$ da especificação DNIT 31/2006.

Estabilidade e Fluência: a estabilidade e a fluência atendem em todas as composições os limites especificados, de 5,0kN (especificação do DNIT 31/2006) e 2.0 a 4.0mm (ES-P 28/05 $\mathrm{DER} / \mathrm{PR})$, respectivamente.

Módulo de resiliência: Os valores maiores de módulos de resiliência na condição nãocondicionado são encontrados nas composições com teores mais baixos de óleo e borracha, enquanto os valores mais baixos são obtidos para altas concentrações de óleo e borracha. Quando condicionados, os valores maiores de módulo são encontrados nas regiões com 
baixas concentrações de óleo e borracha e valores baixos módulos são obtidos nas regiões com altas concentrações de óleo e borracha.

Resistência à tração: Em relação à resistência à tração, todas as composições dentro da região experimental apresentam valores superiores ao determinado pelas especificações do DNIT 31/2006 e ES-P 28/05 DER/PR, que é de 0,65 MPa.

Relação MR/RT: Todas as misturas da região experimental apresentaram valores dessa relação maiores que o valor de 3000, citado comumente pela literatura como desejável. O mesmo comportamento ocorre para relação MR/RT das misturas condicionadas; neste caso, valores próximos são encontrados na região com altas concentrações de óleo e borracha.

Recuperação retardada: Os maiores valores de recuperação retardada são verificados nas regiões com qualquer quantidade de borracha e até concentrações, aproximadamente, de 7\% de óleo.

Relação RMR: Considerando, de maneira similar que a RRT de 70\%, observa-se, com exceção de misturas com altas concentrações de óleo e borracha, que todas as misturas apresentam valores de RMR superiores a esse limite.

Relação RRT: Considerando o limite mínimo de RRT de 70\%, seriam admissíveis todas as composições com exceção das com altas concentrações de óleo e borracha.

\subsection{Conclusões obtidas da análise de efeito dos componentes}

\subsubsection{Borracha moída}

Neste item serão apresentadas as principais conclusões da análise de efeito de componentes em relação à concentração de borracha moída:

Parâmetros volumétricos: em relação ao efeito de concentração de borracha moída pode-se dizer que o aumento da proporção de borracha, geralmente, implica na redução da densidade 
aparente e da relação betume-vazios e no aumento do volume de vazios e dos vazios do agregado mineral.

Estabilidade e Fluência: A estabilidade e a fluência Marshall aumentam para as concentrações de 0 a $9 \%$ e reduzem para proporções de 9 a $18 \%$ de borracha.

Módulo de resiliência: $\mathrm{Na}$ temperatura de $25^{\circ} \mathrm{C}$, a borracha tende a reduzir o valor do módulo de resiliência não-condicionado, desde que sejam empregados teores intermediários a altos, ou seja, concentrações acima de $8 \%$. Após o condicionamento, a borracha mantém a tendência de reduzir o módulo de resiliência, porém linearmente.

Resistência à tração: A adição da borracha proporciona uma redução linear na resistência à tração não-condicionada; esta tendência se mantém após o condicionamento. Vale ressaltar que a análise após o condicionado foi realizada para o teor de ligante de 5,0\%.

Relação MR/RT: A tendência global do efeito da proporção de borracha na relação MR/RT nas misturas antes do condicionamento é parabólica, com ponto de máximo em torno dos $9 \%$, isto é, essa relação aumenta para proporções entre 0 a $9 \%$ e se reduz para proporções entre 9 a 18\%. A tendência global do efeito da borracha sobre essa relação para as misturas após o condicionamento é similar à obtida para as misturas antes do condicionamento.

Recuperação retardada: A tendência da borracha é diminuir a recuperação retardada; no entanto, quando as misturas são condicionadas, o efeito da borracha á parabólico, com ponto de máximo em torno dos $8 \%$, ou seja, a borracha proporciona um aumento da RR entre as concentrações de 0 a $8 \%$ e a diminuiu em concentrações superiores.

Relação RMR: O efeito da borracha sobre a relação de módulo de resiliência total (RMR) é parabólico, apresentando ponto de mínimo em torno de $14 \%$, ou seja, proporciona a diminuição da relação até a concentração de $14 \%$ e o seu aumento para concentrações entre 14 a $18 \%$.

Relação RRT: A adição de borracha reduz linearmente a relação da resistência à tração (RRT). Como a tendência da borracha é reduzir tanto a RT não-condicionada quanto a condicionada, a redução da relação RRT pode ser justificada pelo fato do efeito da borracha 
ser mais intenso na redução da RT condicionada do que sobre a RT não-condicionada. O aumento da proporção da borracha prejudica a resistência ao efeito da água em relação à RT.

\subsubsection{Resíduo de óleo de xisto}

Neste item serão apresentadas as principais conclusões da análise de efeito de componentes em relação à concentração do resíduo do óleo de xisto:

Parâmetros volumétricos: Em linhas gerais, o óleo aumenta a densidade aparente para concentrações de 0 a 7\% e a reduz para concentrações superiores. Em relação ao volume de vazios, o óleo apresenta efeito parabólico, ou seja, diminui o valor do Vv até a concentração de $10 \%$ e o aumenta para concentrações de 10 a $14 \%$. A tendência do óleo é reduzir os vazios de agregado mineral. Quanto ao efeito sobre a relação betume-vazios, ele é parabólico, com ponto de máximo em torno dos 7\%, isto é, aumenta a RBV até a concentração de $7 \%$ e a diminui para concentrações entre 7 a $14 \%$.

Estabilidade e Fluência: A fluência é reduzida linearmente pelo efeito do óleo e este efeito é mais intenso do que o produzido pela borracha nesse parâmetro; essa mesma tendência é observada para a estabilidade.

Módulo de resiliência: A tendência do óleo é reduzir o módulo de resiliência das misturas não-condicionadas, com efeito, aproximadamente, linear. O mesmo comportamento é observado para os módulos de resiliência das misturas condicionadas.

Resistência à tração: $O$ efeito do óleo sobre a resistência à tração é de reduzi-la linearmente e de forma mais intensa que a borracha; nota-se esse mesmo comportamento para a resistência à tração das misturas condicionadas.

Relação MR/RT: O óleo proporciona a redução da relação MR/RT das misturas nãocondicionadas e condicionadas, como a tendência global do óleo é reduzir tanto o módulo de resiliência quanto a resistência à tração, a redução dessa relação pode ser justificada pelo fato 
do efeito do óleo ser mais intenso sobre a redução do módulo de resiliência do que sobre a resistência à tração.

Recuperação retardada: A tendência do óleo é aumentar a recuperação retardada, apresentando pouco efeito em altas concentrações. Na recuperação retardada das misturas condicionadas observa-se o mesmo comportamento, porém com uma redução mais intensa dessa propriedade.

Relação RMR: A relação entre os módulos de resiliência das misturas condicionadas e nãocondicionadas com adição de óleo tende a aumentar até a concentração de $10 \%$ e diminuir para concentrações maiores. A diminuição da relação RMR se justifica, pois em concentrações baixas e intermediárias de óleo seu efeito é mais intenso sobre o módulo de resiliência das misturas não-condicionadas do que sobre os das condicionadas.

Relação RRT: O efeito do óleo sobre a relação RRT é parabólico, tendo ponto de máximo em torno dos $8 \%$, ou seja, aumenta o valor da relação nas concentrações entre 0 e $8 \%$ e o diminui nas concentrações de 8 a 14\%. A tendência do efeito do óleo é reduzir a resistência à tração tanto das misturas não-condicionadas como das condicionadas, quando se emprega concentrações até $8 \%$, com maior reflexo na resistência à tração das misturas nãocondicionadas que nas condicionadas. $\mathrm{O}$ aumento da concentração de óleo contribui com o aumento da resistência à ação da água quando empregado proporções de até $8 \%$ e é prejudicial em concentrações superiores.

\subsection{Considerações Finais}

A análise de efeitos dos componentes mostra que, em alguns casos, os efeitos da borracha e do óleo são antagônicos, o que indica que combinações adequadas dos dois modificadores podem ser realizadas, almejando alcançar os níveis desejados para as propriedades do ligante asfalto-borracha e das misturas asfálticas.

No caso do VAM, estabilidade, fluência e resistência à tração todas as misturas conseguiram atender os requisitos estabelecidos pelas especificações. No entanto, para os valores de 
volume de vazios, $\mathrm{RBV}$, relação de módulo de resiliência (RMR) e relação da resistência à tração (RRT) apenas as misturas próximas a região experimental com alta concentração de óleo e de borracha não conseguiram se enquadrar em todos os requisitos das especificações.

Quanto às propriedades mecânicas das misturas asfálticas, tanto a borracha quanto o óleo são críticos em relação à resistência à tração, porém os valores obtidos são maiores que os estabelecidos pelas especificações do DNIT 031/2006 e ES-P 28/05 DER/PR. Em relação à resistência ao dano provocado pela água, o efeito da borracha é prejudicial, no entanto, o efeito do óleo é benéfico. Cabe ressaltar que, embora algumas propriedades melhorem com a adição do óleo e outras não, o ganho na trabalhabilidade da mistura asfáltica é considerável. 


\section{Capítulo 6}

REFERÊNCIAS BIBLIOGRÁFICAS

ABDELRAHMAN, M.A; CARPENTER, S.H (1999). Mechanism of interaction of asphalt cement with crumb rubber modifier. Transportation Research Record, Washington, n.1661, p.106-113.

ANTUNES, A. Estudo por ressonância paramagnética eletrônica da fotodegradação de petróleo brasileiro sob luz solar. 2001. Dissertação (Mestrado em Física). Universidade Estadual de Londrina - UEL/PR, 2001.

AMARAL, S.C. Estudos de misturas asfálticas densas com agregados do estado do Pará, utilizando asfalto convencional (CAP-40) e asfalto modificado com polímero SBS (BETUFLEX B 65/60). 2000. 147p. São Carlos. Dissertação (Mestrado em Transportes) Escola de Engenharia de São Carlos, Universidade de São Paulo.

AMERICAN SOCIETY FOR TESTING AND MATERIALS. ASTM D 4867 - Standard Test Method for Effect of Moisture on Asphalt Concrete Paving Mixtures, Philadelphia, 1996.

AMERICAN SOCIETY FOR TESTING AND MATERIALS. ASTM C 128 -93 Standard Test Method for Specific Gravity and Absorption of fine aggregate, Philadelphia, 2004

AMERICAN SOCIETY FOR TESTING AND MATERIALS. ASTM C 127 -01 Standard Test Method for Specific Gravity and Absorption of fine aggregate, Philadelphia, 2004

ASSOCIAÇÃO BRASILEIRA DE NORMAS TÉCNICAS. NBR 12891 - Dosagem de misturas betuminosas pelo método Marshall. Rio de Janeiro, 1993.

ASSOCIAÇÃO NACIONAL DE INDÚSTRIA DOS PNEUMÁTICOS - ANIP. Disponível em: www.anip.com.br acessado em 01/03/2007.

BARROS, R.V \& VASCONCELLOS, F.S. Pioneer experience with the application of gap graded asphalt rubber mixes in São Paulo, Brazil. Asphalt Rubber 2003 - Proceedings, Brazilia, Brazil, p. 655-667, 2003. 
BERTOLLO, S.A.M. Avaliação Laboratorial de Misturas Asfálticas Densas Modificadas com borracha Reciclada de Pneus. 2002. Tese (Doutorado em Transportes) Escola de Engenharia de São Carlos-EESC. Universidade de São Paulo. São Carlos.

BILLITER, T.C et al. Production of asphalt-rubber binders by high-cure conditions. Transportation Research Record, Washington, n.1586, p.50-56, 1997.

BRÛLÉ, B. Polymer-Modified asphalt cements used in the road construction industry: basic principles. Transportation Research Record, Washington, n.1535, p.48-53, (1996).

CAMPOS, B.A.L. et al. Asfalto-borracha - uma novidade com 40 anos de existência! In: REUNIÃO ANUAL DE PAVIMENTAÇÃO, 32., Brasília. 2000. Anais. Brasília, Associação Brasileira de Pavimentação. V1, p. 212-221, 2000.

CIMINO, M. A. Gerenciamento de pneumáticos inservíveis: análise crítica de procedimentos operacionais e tecnologias para minimização, adotadas no território nacional. 2004. 178p. Dissertação (Mestrado em Engenharia Urbana). Universidade Federal de São Carlos - UFSCAR, São Carlos.

CONFEDERAÇÃO NACIONAL DE TRANSPORTES (CNT). Pesquisa Rodoviária 2007. Disponível em: http://www.cnt.org.br/ acessado em 20/12/2007.

CORDEIRO, W. R. Comportamento de Concretos Asfálticos Projetados com Cimento Asfáltico Modificado por Borracha de Pneus. 2006. 256p. Rio de Janeiro, Dissertação (Mestrado em Ciência em Engenharia de Transportes) Instituto Militar de Engenharia, Rio de Janeiro.

CORNELL, J.A. Experiments with mixtures: design, models, and the analysis of mixture data. $3^{\text {rd }}$.ed. New York: John Wiley, 2002.

DANTAS NETO, S. A. Avaliação das Propriedades dos Ligantes e das Misturas asfálticas Modificados com Borracha Granulada de Pneus Usados. 2004. 265p. Teses (Doutorado em Geotecnia), Departamento de Engenharia Civil e Ambiental, Universidade de Brasília, Brasília, DF.

DEPARTAMENTO DE ESTRADAS DE RODAGEM DO PARANÁ. DER/PR ES-P 28/05. Pavimentação: Concreto Asfáltico Usinado a Quente com Asfalto Borracha. Curitiba, Paraná, 2005. 
DEPARTAMENTO ESTADUAL DE INFRA-ESTRUTURA DO ESTADO DE SANTA CATARINA. DEINFRA/SC ES-P 05B/05. Camadas de Misturas Asfálticas Usinadas a Quente com Asfalto Borracha. Santa Catarina, 2005.

DEPARTAMENTO DE ESTRADAS DE RODAGEM DO ESTADO DE SÃO PAULO. DER/SP ET-DE-P00/030. Concreto Asfáltico com Asfalto-Borracha (Processo úmido). São Paulo, 2007.

DEPARTAMENTO DE ESTRADAS DE RODAGEM. Manual de Estradas e Rodagem. Manual de reabilitação de Pavimentos Asfálticos. Departamento Nacional de Estradas de Rodagem, Diretoria de Desenvolvimento Tecnológico, Divisão de Capacitação Tecnológica IPR. Rio de Janeiro, 1998.

DEPARTAMENTO DE ESTRADAS DE RODAGEM - DNER/ME 043/95. Misturas Betuminosas a quente - Ensaio Marshall. Rio de Janeiro, 1995.

DEPARTAMENTO DE ESTRADAS DE RODAGEM - DNER/ME 138/94. Misturas Betuminosas - Determinação da Resistência à Tração por Compressão Diametral. Rio de Janeiro, 1994.

DEPARTAMENTO DE ESTRADAS DE RODAGEM - DNER/ME 133/94. Misturas Betuminosas - Agregado - Determinação do Módulo de Resiliência. Rio de Janeiro, 1994.

DEPARTAMENTO DE ESTRADAS DE ROGAGEM (1994) DNER/ME 078/94. Agregado graúdo - adesividade a ligante asfálticos. Rio de Janeiro.

DEPARTAMENTO NACIONAL DE INFRA-ESTRUTURA DE TRANSPORTE - DNIT 031/2006 - ES Pavimentos flexíveis - Concreto asfáltico -Especificação de serviço. Rio de Janeiro.

FAXINA, A. L. Estudo em laboratório do desempenho de concreto asfáltico usinado a quente empregando ligante do tipo asfalto-borracha. 2002. 338p. Dissertação (Mestrado em Transportes). Escola de Engenharia de São Carlos-EESC. Universidade de São Paulo. São Carlos.

FAXINA, A.L. Estudo da viabilidade técnica do uso de resíduo de óleo de xisto como óleo extensor em ligante asfalto-borracha. 2006. 308p+apêndices. Tese (Doutorado em Transportes). Escola de Engenharia de São Carlos-EESC. Universidade de São Paulo. São Carlos.

FOX, R.. Introdução à Mecânica dos Fluídos. Editora LTC-Livros Técnicos e Científicos S.A. Rio de Janeiro. RJ. Brasil. 2006. 
FURLAN, A. P. Considerações acerca da adesão e da suscetibilidade à umidade de misturas asfálticas densas à luz de algumas propriedades mecânicas. 2006. 127 p+apêndices. Tese (Doutorado em Transportes). Escola de Engenharia de São CarlosEESC. Universidade de São Paulo. São Carlos.

GALLEGO, J.; M. A. DEL VAL; E R. TOMÁS (2000) A Spanish Experience with Asphalt Pavements Modified with Tire Rubber. Asphalt Rubber 2000, Vilamoura, Portugal, p. 673687.

GALVÃO, M. S Estudo da adição de PVB em misturas asfálticas para pavimentação. 2001. 131p. Dissertação (Mestrado em Engenharia de Infra-Estrutura Aeronáutica na área de Infra-Estrutura de Transportes). Instituto Tecnológico da Aeronáutica - ITA. São José dos Campos, SP, Brasil, 2001.

GRECO, J. A. S. Avaliação da influência de alguns fatores nas propriedades mecânicas de misturas asfálticas à luz da técnica de planejamento e análise de experimentos fatoriais fracionários assimétricos. 2004. 367p. Tese (Doutorado em Transportes). Escola de Engenharia de São Carlos. Universidade de São Paulo. São Carlos.

HANSON, D.I. et al. Evaluation and characterization of a rubber-modified hoi mix asphalt pavement. Transportation Research Record. 1436, p. 98-107, 1994.

HOLLERAN, G. \& REED, J.R. Emulsification of asphalt rubber blends. ASPHALT RUBBER 2000 CONFERENCE- Proceedings, Vilamoura, Portugal, p.383-410, 2000.

SILVA JR, A. Avanço Tecnológico em Pavimentação na malha rodoviária do estado de São Paulo. ARTESP. 2005

Disponível em: http://www.artesp.sp.gov.br/ativa/cartilha_ativa_29a.asp\# acessado em 03/04/2007.

LEITE, L.M.F. Estudos de preparo e caracterização de asfaltos modificados por polímero. 1999. 303p Tese (Doutorado em Ciência e Tecnologia de Polímeros) Universidade Federal do Rio de Janeiro - UFRJ. 303p

LEITE, L.F.M. et al. (2000). Mechanical behavior of asphalt rubber mixes prepared in laboratory. In: ASPHALT RUBBER 2000 CONFERENCE, Vilamoura, 2000. Proceedings. Braga, Barbosa \& Xavier. p.309-318.

LEITE, L.M.F., et al. Mechanical behavior of asphalt rubber mixtures prepared in laboratory. In: ASPHALT RUBBER 2000 CONFERENCE - Proceedings, Vilamoura, Portugal, 2000, p. 309-318, 2000. 
LEITE, L.M.F., et al. Asphalt Rubber in Brazil: Pavement perfomance and laboratory study. In: ASPHALT RUBBER 2003 CONFERENCE - Proceedings, Brazilian, Brazil, 2003, p. 229-246, 2003.

LEMES, P. C. L. (2004) Estudo do envelhecimento a curto prazo de misturas asfálticas densas com cimento asfáltico modificado. 2004. São Carlos, Dissertação (Mestrado em Transportes) - Escola de Engenharia de São Carlos, Universidade de São Paulo.

LEITE, L.F.M, BITTENCOURT, C.P (2004). Caracterização reológico de cimentos asfálticos de petróleo e asfaltos modificados. II Encontro Brasileiro de reologia. Julio 7-9 2004. Rio de Janeiro, RJ, Brasil.

LIMA, A. T. Caracterização Mecânica de Misturas Asfálticas Recicladas a Quente. 2003. Dissertação (Mestrado em Engenharia de Transportes). Programa de Mestrado em Engenharia de Transportes. Universidade Federal do Ceará.

LOIOLA, Conrado (2006). Descarte inadequado de pneus gera prejuízos à sociedade. .http://www.akatu.net/cgi/cgilua.exe/sys/start.htm?tpl=view_tipo2\&sid=88\&infoid=1569 Acessado em:27/02/2007.

MAGAlhãeS, S.T. Misturas Asfálticas de Módulos Elevado para Pavimentos de Alto Desempenho. 2004. 201p. Rio de Janeiro. Dissertação (Mestrado em Ciência em Engenharia Civil) - Universidade Federal do Rio de Janeiro - UFRJ. 184p

MANUAL DE ASFALTO. Instituto de Asfalto. Série do Manual N 4 (MS-4), 1989. MEDINA, J; \& MOTTA, L. M. Mecânica dos Pavimentos. Rio de Janeiro, Editora UFRJ, 2005.

MOHAMMAD, L.N et al. Accelerated loading performance and laboratory characterization of crumb rubber asphalt pavements. In: ASPHALT RUBBER 2000 CONFERENCEProceedings, Vilamoura, Portugal, p. 189-220, 2000.

MOMM, L. \& SALINI, R. Study of recycled in asphalt concrete mixtures. In: ASPHALT RUBBER 2000 CONFERENCE- Proceedings, Vilamoura, Portugal, p. 341-357, 2000.

MORILHA. Jr; GRECA, M.R. (2003) Considerações Relacionadas ao Asfalto EcológicoEcoflex. IEP. Apostila sobre Asfalto Borracha, Instituto de Engenharia do Paraná, 12p, 2003. Disponível em: http://www.iep.org.br/index.php?itemid=29\&catid=14 Acesso em: 28/02/2007.

MOURÃO, F. A. L. Misturas Asfálticas de Alto Desempenho Tipo SMA. Dissertação (Mestrado em Ciência em Engenharia Civil). 2003. 131 p. Universidade Federal do Rio de Janeiro COPPE/UFRJ. 
NASCIMENTO, L. A. H; FIGUEIREDO, L. M; LÁO, V. L. E. S; JESUS, G. F Pavimentos Silenciosos. REUNIÃo ANUAL DE PAVIMENTAÇÃO, 36. - Curitiba/PR - Brasil- 24 a 26 de agosto de 2005.

ODA, Sandra. Análise da viabilidade técnica da utilização do ligante asfalto-borracha em obras de pavimentação. 2000. 251p. Tese (Doutorado em Transportes) - Escola de Engenharia de São Carlos, Universidade de São Paulo.

Reutilização de pneus como alternativa para aumento de vida útil de aterro. Universidade Estadual de Maringá. Anais, 2000.

Laboratórios Baianos desenvolvem tecnologia de asfalto-borracha. Reportagens Especiais. FAPESB, 2007. Disponível em: http://www.fapesb.ba.gov.br/ Acessado em: $01 / 03 / 2007$.

ODA, Sandra; EDEL, G.; FERNANDES JR, J. L. Primeiro Trecho Experimental Urbano de SMA com Asfalto-Borracha sem Fibras: Projeto, Construção e Avaliação. Revista Minerva Pesquisa e Tecnologia, São Carlos-SP, v. 2, n. 2, p. 203-216, 2005.

PATRIOTA, M.B. de. Análise laboratorial de concreto betuminoso usinado a quente modificado com adição de borracha reciclada de pneus - processo seco. 2004.6 149p. Dissertação (Mestrado em Ciência em Engenharia Civil). Universidade Federal de Pernambuco. Departamento de Engenharia Civil, Recife, PE.

PINHEIRO, JH.M. \& SOARES, JB. The effect of crumb rubber gradation and binder-rubber interaction time on the mechanical properties of asphalt- rubber mixtures (dry process). In: ASPHALT RUBBER 2003 CONFERENCE- Proceedings, Brazilian, Brazil, p. 707-718, 2003.

PINHEIRO, J.H.M. Incorporação de Borracha de Pneu em Misturas Asfálticas de Diferentes Granulometrias (Processos Úmido e Seco). 2004. 166p. Dissertação (Mestrado em Transportes), Universidade Federal do Ceará, Fortaleza, CE.

PINHEIRO, Jorge Henrique Magalhães; SOARES, Jorge Barbosa; LEITE, Leni Mathias. Caracterização de Misturas Asfálticas com Borracha Produzidas pelos Processos Úmido e Seco. In: CONGRESSO DE PESQUISA E ENSINO DE TRANSPORTES, 17. 2003. Rio de Janeiro. Anais. ANPET.

ROSENO, J. L. (2005). Avaliação de uma Mistura Asfáltica Porosa com Agregados Calcários e Asfalto-borracha. Dissertação (Mestrado em Geotecnia) 2005. - Universidade de Brasília, Brasília, DF. 
SANTOS, C. R. G Avaliação das influências do tipo de ligante e volume de vazios na vida de fadiga de algumas misturas asfálticas. 2005. Mestrado (Dissertação em Transportes). Escola de Engenharia de São Carlos da Universidade de São Paulo, São Carlos.

SALINI, R. B; MARCON, A. F. Utilização de borracha reciclada de pneus em misturas asfálticas. IN: Encontro Ibero-Americano de Unidades Ambientais do Setor de Transportes, 3. Florianópolis - Santa Catarina, 1998.

SEVERO, L., et al. Performance of asphalt-rubber hot mix overlays at brazilian highway. In: ASPHALT RUBBER 2003 CONFERENCE - Proceedings, Brazilian, Brazil: 633-643, 2003.

SOUSA, J.M.D. et al. Caracterização laboratorial preliminar de misturas asfálticas modifica com borracha reciclada de pneus e convencional para projetos de recuperação de rodovias do DER/DF. In: REUNIÃO ANUAL DE PAVIMENTAÇÃO, 32. Brasília. 2000. Anais. Brasília, Associação Brasileira de Pavimentação. V1, p. 224-234, 2000.

SPECHT, L.P. Avaliação de misturas asfálticas com incorporação de borracha reciclada de pneus. (2004) - Tese (doutorado) Programa de Pós-Graduação em Engenharia Civil da Universidade Federal do Rio Grande do Sul. UFRGS.Porto Alegre: PPGEC/UFRGS, 2004.

SPECHT, L.P; CERATTI, JA.P. \& PALUDO, I. Laboratorial evaluation of tire rubber use as hot mix aggregate. In: ASPHALT RUBBER 2003 CONFERENCE - Proceedings, Brazilian, Brazil, 2003, p 603-614, 2003.

STROUP-GARDINER, M. et al. Asphalt-rubber interactions. Transportation Research Record. Washington, n.1417, p.99-108, 1993.

TAIRA, Cláudio Avaliação do desempenho em laboratório de misturas asfálticas densas utilizando asfalto convencional (CAP-20) e asfalto modificado com polímero SBS. 2001. Dissertação (Mestrado em Transportes) - Escola de Engenharia de São Carlos, Universidade de São Paulo.

TAKALLOU, H.B \& TAKALLOU, M. B. Effects of mixing time and temperature on the visco-elastic properties of asphalt rubber binder. In: ASPHALT RUBBER 2003 CONFERENCE - Proceedings, Brazilian, Brazil, 2003, p 589-602, 2003.

VISSER, A.T. \& VERHAEGHE, B. (2000). Bitum em rubber: lessons in South África. In: ASPHALT RUBBER 2000 CONFERENCE- Proceedings, Brazilian. Brazil, p 49-63, 2000.

Disponível em:

http://www.estado.rs.gov.br/index.php?inc=noticias/noticias_view.php\&notid=47502 
Planilha de dosagem Marshall - ligante asfáltico 1 (100-0-0)

dens. efetiva do agregado

dens. ponderada dos agregados

dens. do ligante asfáltico
2,869

2,869

1,004

Tabela A1: Parâmetros Marshall para mistura 100-0-0

\begin{tabular}{|c|c|c|c|c|c|c|c|c|c|c|c|c|c|c|c|}
\hline $\begin{array}{c}\mathbf{N}^{\circ} \\
\text { do } \mathrm{CP} \\
\end{array}$ & $\begin{array}{c}\% \\
\text { ligante } \\
\end{array}$ & $\begin{array}{c}\% \\
\text { ligante } \\
\end{array}$ & $\begin{array}{c}\% \\
\text { agreg } \\
\end{array}$ & $\begin{array}{c}\text { massa } \\
\text { ao ar }\end{array}$ & $\begin{array}{c}\text { massa } \\
\text { imersa }\end{array}$ & $\begin{array}{c}\text { massa } \\
\text { SSS } \\
\end{array}$ & $\begin{array}{c}\text { volume } \\
\text { CP }\end{array}$ & $\begin{array}{c}\text { Diâmetro } \\
\text { médio }\end{array}$ & $\begin{array}{l}\text { Altura } \\
\text { média }\end{array}$ & $\begin{array}{c}\text { absorção } \\
\text { de água }\end{array}$ & $\begin{array}{c}\text { D } \\
\text { ap }\end{array}$ & $\begin{array}{l}\text { DMM } \\
\text { média } \\
\end{array}$ & $\begin{array}{l}\text { Vv } \\
(\%) \\
\end{array}$ & $\begin{array}{c}\text { VAM } \\
(\%) \\
\end{array}$ & $\begin{array}{r}\text { RBV } \\
(\%) \\
\end{array}$ \\
\hline $1-1 \mathrm{~A}$ & 4,5 & 0,045 & 95,5 & 1203,3 & 710,9 & 1206,9 & 492 & 10,160 & 6,210 & 0,73 & 2,426 & 2,649 & 8,4 & 19,2 & 56,3 \\
\hline $2-1 \mathrm{~A}$ & 4,5 & 0,045 & 95,5 & 1199,7 & 708,4 & 1201,5 & 491 & 10,170 & 6,110 & 0,37 & 2,433 & 2,649 & 8,2 & 19,0 & 57,1 \\
\hline $3-1 \mathrm{~A}$ & 4,5 & 0,045 & 95,5 & 1221,0 & 723,0 & 1223,2 & 498 & 10,180 & 6,220 & 0,44 & 2,441 & 2,649 & 7,8 & 18,7 & 58,1 \\
\hline $4-1 \mathrm{~A}$ & 4,5 & 0,045 & 95,5 & 1219,1 & 720,7 & 1220,8 & 498 & 10,190 & 6,190 & 0,34 & 2,438 & 2,649 & 8,0 & 18,9 & 57,7 \\
\hline $5-1 \mathrm{~A}$ & 4,5 & 0,045 & 95,5 & 1208,4 & 714,8 & 1210,2 & 494 & 10,180 & 6,180 & 0,36 & 2,439 & 2,649 & 7,9 & 18,8 & 57,9 \\
\hline $6-1 \mathrm{~A}$ & 4,5 & 0,045 & 95,5 & 1213,1 & 717,9 & 1214,9 & 495 & 10,170 & 6,200 & 0,36 & 2,441 & 2,649 & 7,9 & 18,8 & 58,1 \\
\hline $7-1 \mathrm{~A}$ & 4,5 & 0,045 & 95,5 & 1205,9 & 714,7 & 1208,3 & 491 & 10,180 & 6,180 & 0,49 & 2,443 & 2,649 & 7,8 & 18,7 & 58,4 \\
\hline médias & 4,5 & 0,045 & 95,5 & 1210,1 & 715,8 & 1212,3 & 494 & 10,176 & 6,184 & 0,44 & 2,437 & 2,649 & 8,0 & 18,9 & 57,7 \\
\hline $1-1 \mathrm{~B}$ & 5,0 & 0,05 & 95 & 1214,6 & 722,1 & 1216,2 & 493 & 10,150 & 6,170 & 0,32 & 2,458 & 2,626 & 6,4 & 18,6 & 65,6 \\
\hline $2-1 B$ & 5,0 & 0,05 & 95 & 1201,4 & 716,4 & 1202,4 & 485 & 10,180 & 6,060 & 0,21 & 2,472 & 2,626 & 5,9 & 18,1 & 67,6 \\
\hline $3-1 B$ & 5,0 & 0,05 & 95 & 1210,9 & 719,3 & 1212,4 & 492 & 10,170 & 6,130 & 0,30 & 2,456 & 2,626 & 6,5 & 18,7 & 65,2 \\
\hline 4-1B & 5,0 & 0,05 & 95 & 1208,4 & 717,9 & 1210,3 & 491 & 10,170 & 6,140 & 0,39 & 2,454 & 2,626 & 6,6 & 18,7 & 65,0 \\
\hline $5-1 B$ & 5,0 & 0,05 & 95 & 1203,7 & 717,7 & 1204,9 & 486 & 10,160 & 6,090 & 0,25 & 2,471 & 2,626 & 5,9 & 18,2 & 67,4 \\
\hline $6-1 B$ & 5,0 & 0,05 & 95 & 1203,4 & 715,5 & 1204,8 & 488 & 10,170 & 6,120 & 0,29 & 2,459 & 2,626 & 6,4 & 18,6 & 65,8 \\
\hline $7-1 \mathrm{~B}$ & 5,0 & 0,05 & 95 & 1201,6 & 714,1 & 1203,5 & 488 & 10,160 & 6,100 & 0,39 & 2,455 & 2,626 & 6,5 & 18,7 & 65,2 \\
\hline médias & 5,0 & 0,05 & 95 & 1206,3 & 717,6 & 1207,8 & 489 & 10,166 & 6,116 & 0,31 & 2,461 & 2,626 & 6,3 & 18,5 & 66,0 \\
\hline
\end{tabular}




\begin{tabular}{|c|c|c|c|c|c|c|c|c|c|c|c|c|c|c|c|}
\hline $\begin{array}{c}\mathbf{N}^{\circ} \\
\text { do CP }\end{array}$ & $\begin{array}{c}\text { ‘\% } \\
\text { ligante }\end{array}$ & $\begin{array}{c}\% \\
\text { ligante }\end{array}$ & $\begin{array}{c}\% \\
\text { agreg }\end{array}$ & $\begin{array}{c}\text { massa } \\
\text { ao ar }\end{array}$ & $\begin{array}{l}\text { massa } \\
\text { imersa }\end{array}$ & $\begin{array}{c}\text { massa } \\
\text { SSS }\end{array}$ & $\begin{array}{c}\text { volume } \\
\text { CP }\end{array}$ & $\begin{array}{c}\text { Diâmetro } \\
\text { médio }\end{array}$ & $\begin{array}{l}\text { Altura } \\
\text { média }\end{array}$ & $\begin{array}{c}\text { absorção } \\
\text { de água }\end{array}$ & $\begin{array}{c}\text { D } \\
\text { ap }\end{array}$ & $\begin{array}{l}\text { DMM } \\
\text { média }\end{array}$ & $\begin{array}{c}\text { Vv } \\
(\%)\end{array}$ & $\begin{array}{c}\text { VAM } \\
(\%)\end{array}$ & $\begin{array}{r}\text { RBV } \\
(\%)\end{array}$ \\
\hline $1-1 \mathrm{C}$ & 5,5 & 0,055 & 94,5 & 1218,7 & 728,1 & 1219,4 & 491 & 10,170 & 6,140 & 0,14 & 2,481 & 2,604 & 4,7 & 18,3 & 74,0 \\
\hline $2-1 \mathrm{C}$ & 5,5 & 0,055 & 94,5 & 1205,0 & 722,5 & 1205,5 & 483 & 10,180 & 6,010 & 0,10 & 2,495 & 2,604 & 4,2 & 17,8 & 76,4 \\
\hline $4-1 \mathrm{C}$ & 5,5 & 0,055 & 94,5 & 1209,9 & 726,7 & 1210,6 & 483 & 10,160 & 6,040 & 0,14 & 2,500 & 2,604 & 4,0 & 17,6 & 77,4 \\
\hline $5-1 \mathrm{C}$ & 5,5 & 0,055 & 94,5 & 1198,0 & 719,4 & 1199,8 & 479 & 10,170 & 6,050 & 0,37 & 2,494 & 2,604 & 4,2 & 17,9 & 76,2 \\
\hline médias & 5,5 & 0,055 & 94,5 & 1205,0 & 723,2 & 1206,3 & 482 & 10,160 & 6,020 & 0,26 & 2,494 & 2,604 & 4,2 & 17,8 & 76,4 \\
\hline $1-1 \mathrm{D}$ & 6,0 & 0,06 & 94 & 1203,4 & 722,8 & 1203,7 & 481 & 10,160 & 5,990 & 0,06 & 2,502 & 2,582 & 3,1 & 18,0 & 82,8 \\
\hline $2-1 \mathrm{D}$ & 6,0 & 0,06 & 94 & 1200,1 & 722,9 & 1200,5 & 477 & 10,150 & 5,970 & 0,08 & 2,513 & 2,582 & 2,7 & 17,7 & 84,7 \\
\hline $3-1 \mathrm{D}$ & 6,0 & 0,06 & 94 & 1211,5 & 730,9 & 1212,2 & 481 & 10,160 & 6,020 & 0,15 & 2,517 & 2,582 & 2,5 & 17,5 & 85,6 \\
\hline $4-1 \mathrm{D}$ & 6,0 & 0,06 & 94 & 1210,5 & 729,6 & 1211,3 & 481 & 10,160 & 6,010 & 0,17 & 2,513 & 2,582 & 2,7 & 17,7 & 84,8 \\
\hline médias & 6,0 & 0,06 & 94 & 1209,1 & 728,6 & 1209,8 & 480 & 10,159 & 6,031 & 0,15 & 2,513 & 2,582 & 2,7 & 17,7 & 84,7 \\
\hline $1-1 \mathrm{E}$ & 6,5 & 0,065 & 93,5 & 1208,4 & 731,8 & 1208,8 & 477 & 10,160 & 5,970 & 0,08 & 2,533 & 2,561 & 1,1 & 17,4 & 93,8 \\
\hline $2-1 \mathrm{E}$ & 6,5 & 0,065 & 93,5 & 1208,9 & 732,2 & 1209,1 & 477 & 10,150 & 5,970 & 0,04 & 2,535 & 2,561 & 1,0 & 17,4 & 94,1 \\
\hline $3-1 E$ & 6,5 & 0,065 & 93,5 & 1211,2 & 733,5 & 1211,3 & 478 & 10,170 & 5,960 & 0,02 & 2,535 & 2,561 & 1,0 & 17,4 & 94,1 \\
\hline 4-1E & 6,5 & 0,065 & 93,5 & 1196,9 & 723,7 & 1197,1 & 473 & 10,160 & 5,930 & 0,04 & 2,528 & 2,561 & 1,3 & 17,6 & 92,7 \\
\hline $5-1 \mathrm{E}$ & 6,5 & 0,065 & 93,5 & 1209,8 & 733,9 & 1210,1 & 476 & 10,150 & 5,990 & 0,06 & 2,541 & 2,561 & 0,8 & 17,2 & 95,3 \\
\hline $6-1 E$ & 6,5 & 0,065 & 93,5 & 1194,5 & 724,4 & 1194,7 & 470 & 10,160 & 5,870 & 0,04 & 2,540 & 2,561 & 0,8 & 17,2 & 95,2 \\
\hline $7-1 \mathrm{E}$ & 6,5 & 0,065 & 93,5 & 1210,4 & 733,9 & 1211,2 & 477 & 10,160 & 5,980 & 0,17 & 2,536 & 2,561 & 1,0 & 17,4 & 94,4 \\
\hline médias & 6,5 & 0,065 & 93,5 & 1205,7 & 730,49 & 1206 & 475 & 10,159 & 5,953 & $\mathbf{0 , 0 7}$ & 2,535 & 2,561 & 1,0 & 17,4 & 94,2 \\
\hline
\end{tabular}




\begin{tabular}{c|c|c|c|c}
\hline $\begin{array}{c}\text { Teor } \\
(\mathbf{\%})\end{array}$ & $\begin{array}{c}\text { Dap } \\
\left(\mathbf{g} / \mathbf{c m}^{3}\right)\end{array}$ & $\mathbf{V v} \mathbf{( \% )}$ & $\begin{array}{c}\text { VAM } \\
\mathbf{( \% )}\end{array}$ & $\mathbf{R B V ( \% )}$ \\
\hline 4,5 & 2,437 & 8,0 & 18,9 & 57,7 \\
\hline 5,0 & 2,461 & 6,3 & 18,5 & 66,0 \\
\hline 5,5 & 2,494 & 4,2 & 17,8 & 76,4 \\
\hline 6,0 & 2,513 & 2,7 & 17,7 & 84,7 \\
\hline 6,5 & 2,535 & 1,0 & 17,4 & 94,2 \\
\hline
\end{tabular}

\section{Ensaio Marshall - Mistura 1}
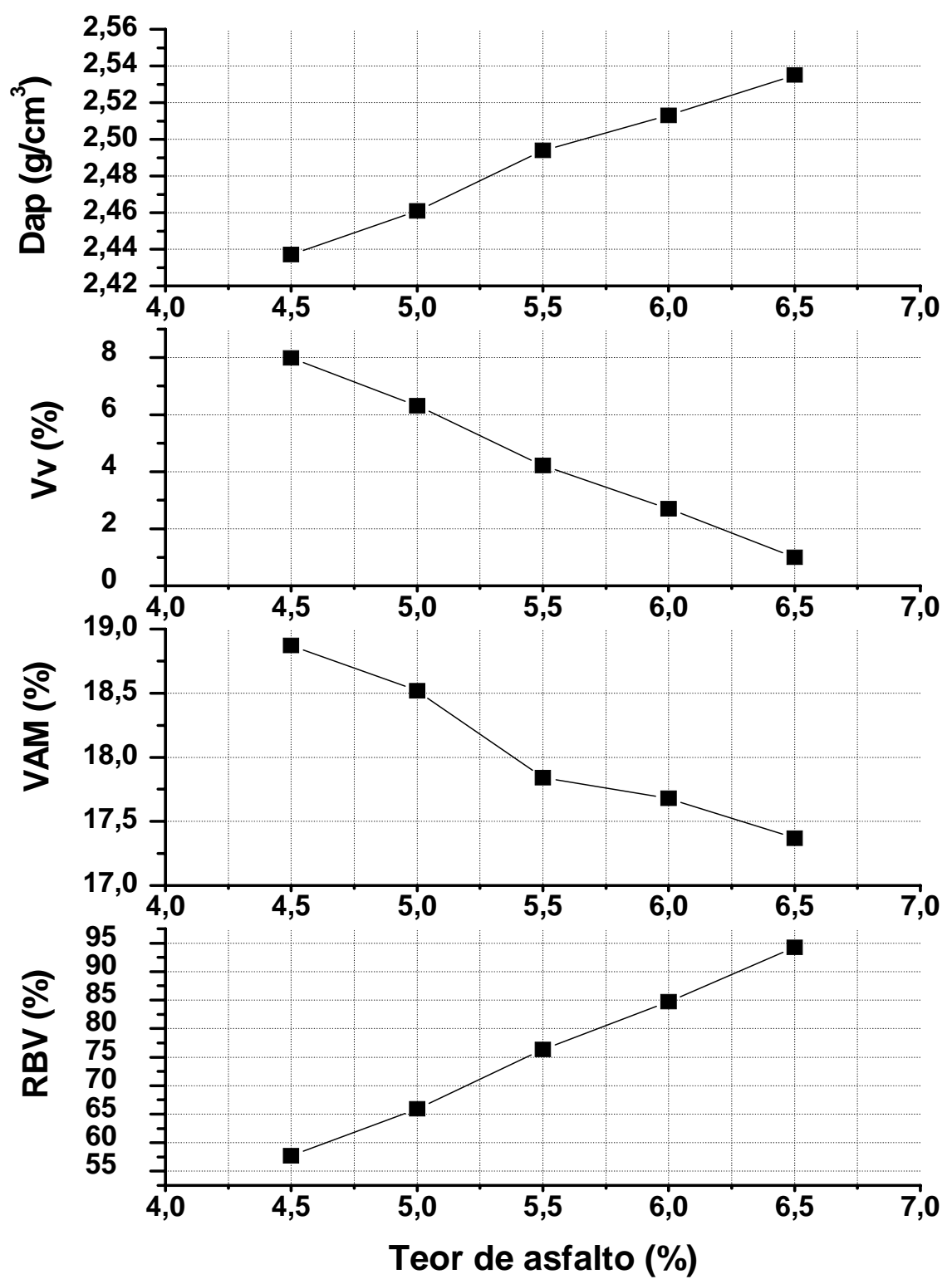

Figura A1: Parâmetros Marshall para mistura 100-0-0 
Planilha de dosagem Marshall - ligante asfáltico 2 (93-0-7)

dens. efetiva do agregado $\quad 2,869$

dens. ponderada dos agregados $\quad 2,869$

dens. do ligante asfáltico $\quad 1,012$

Tabela A2: Parâmetros Marshall para mistura 93-0-7

\begin{tabular}{|c|c|c|c|c|c|c|c|c|c|c|c|c|c|}
\hline $\begin{array}{c}\text { número } \\
\text { do CP }\end{array}$ & $\begin{array}{c}\% \\
\text { ligante }\end{array}$ & $\begin{array}{c}\% \\
\text { ligante }\end{array}$ & $\begin{array}{c}\% \\
\text { agreg }\end{array}$ & $\begin{array}{c}\text { massa } \\
\text { ao ar }\end{array}$ & $\begin{array}{l}\text { massa } \\
\text { imersa }\end{array}$ & $\begin{array}{c}\text { massa } \\
\text { SSS }\end{array}$ & $\begin{array}{c}\text { volume } \\
\text { CP }\end{array}$ & $\begin{array}{c}\text { absorção } \\
\text { de água }\end{array}$ & $\begin{array}{l}\text { D } \\
\text { ap }\end{array}$ & $\begin{array}{l}\text { DMM } \\
\text { média }\end{array}$ & $\begin{array}{l}\mathrm{Vv} \\
(\%)\end{array}$ & $\begin{array}{c}\text { VAM } \\
(\%)\end{array}$ & $\begin{array}{l}\text { RBV } \\
(\%)\end{array}$ \\
\hline $1-2 \mathrm{~A}$ & 4,5 & 0,045 & 95,5 & 1206,1 & 722,7 & 1209,5 & 483 & 0,70 & 2,478 & 2,650 & 6,5 & 17,5 & 62,9 \\
\hline $2-2 \mathrm{~A}$ & 4,5 & 0,045 & 95,5 & 1204,9 & 724,5 & 1208,2 & 480 & 0,68 & 2,491 & 2,650 & 6,0 & 17,1 & 64,8 \\
\hline $3-2 \mathrm{~A}$ & 4,5 & 0,045 & 95,5 & 1204,0 & 724,2 & 1207,6 & 480 & 0,74 & 2,491 & 2,650 & 6,0 & 17,1 & 64,8 \\
\hline $4-2 \mathrm{~A}$ & 4,5 & 0,045 & 95,5 & 1210,2 & 727,6 & 1214 & 483 & 0,78 & 2,488 & 2,650 & 6,1 & 17,2 & 64,4 \\
\hline $5-2 \mathrm{~A}$ & 4,5 & 0,045 & 95,5 & 1214,7 & 730,7 & 1218,8 & 484 & 0,84 & 2,489 & 2,650 & 6,1 & 17,2 & 64,5 \\
\hline $6-2 \mathrm{~A}$ & 4,5 & 0,045 & 95,5 & 1209,2 & 728,5 & 1213,8 & 481 & 0,95 & 2,492 & 2,650 & 6,0 & 17,1 & 64,9 \\
\hline $7-2 \mathrm{~A}$ & 4,5 & 0,045 & 95,5 & 1208,0 & 727,3 & 1211,6 & 481 & 0,74 & 2,494 & 2,650 & 5,9 & 17,0 & 65,3 \\
\hline médias & 4,5 & 0,045 & 95,5 & 1208,2 & 726,5 & 1211,9 & 481,657 & 0,776836 & 2,4889 & 2,6502 & 6,1 & 17,2 & 64,5 \\
\hline $1-2 B$ & 5,0 & 0,05 & 95 & 1213,0 & 732,1 & 1215,1 & 481 & 0,43 & 2,511 & 2,628 & 4,4 & 16,8 & 73,7 \\
\hline $2-2 B$ & 5,0 & 0,05 & 95 & 1202,3 & 725,7 & 1204,5 & 477 & 0,46 & 2,511 & 2,628 & 4,4 & 16,9 & 73,6 \\
\hline $3-2 B$ & 5,0 & 0,05 & 95 & 1216,6 & 734,5 & 1218,9 & 482 & 0,47 & 2,512 & 2,628 & 4,4 & 16,8 & 73,7 \\
\hline $4-2 B$ & 5,0 & 0,05 & 95 & 1218,7 & 736,3 & 1222,3 & 482 & 0,74 & 2,508 & 2,628 & 4,6 & 17,0 & 73,0 \\
\hline $5-2 B$ & 5,0 & 0,05 & 95 & 1224,6 & 736,1 & 1227,9 & 489 & 0,67 & 2,490 & 2,628 & 5,2 & 17,5 & 70,1 \\
\hline $6-2 B$ & 5,0 & 0,05 & 95 & 1206,5 & 727,6 & 1210,9 & 479 & 0,91 & 2,496 & 2,628 & 5,0 & 17,3 & 71,1 \\
\hline $7-2 B$ & 5,0 & 0,05 & 95 & 1227,3 & 740,7 & 1229,9 & 487 & 0,53 & 2,509 & 2,628 & 4,5 & 16,9 & 73,2 \\
\hline médias & 5,0 & 0,05 & 95 & 1215,6 & 733,29 & 1218,5 & 482,286 & 0,603245 & 2,5053 & 2,6279 & 4,7 & 17,0 & 72,6 \\
\hline número & $\%$ & $\%$ & $\%$ & massa & massa & massa & volume & absorção & D & DMM & $\mathbf{V v}$ & VAM & RBV \\
\hline
\end{tabular}




\begin{tabular}{|c|c|c|c|c|c|c|c|c|c|c|c|c|c|}
\hline do CP & ligante & ligante & agreg & ao ar & imersa & SSS & $\mathbf{C P}$ & de água & ap & média & $(\%)$ & (\%) & $(\%)$ \\
\hline $2-2 C$ & 5,5 & 0,055 & 94,5 & 1217,4 & 734,7 & 1218,8 & 483 & 0,29 & 2,515 & 2,606 & 3,5 & 17,2 & 79,6 \\
\hline $3-2 \mathrm{C}$ & 5,5 & 0,055 & 94,5 & 1202,5 & 725,5 & 1203,1 & 477 & 0,13 & 2,518 & 2,606 & 3,4 & 17,1 & 80,2 \\
\hline $4-2 \mathrm{C}$ & 5,5 & 0,055 & 94,5 & 1211,9 & 732,8 & 1214,1 & 479 & 0,46 & 2,518 & 2,606 & 3,4 & 17,1 & 80,2 \\
\hline $5-2 \mathrm{C}$ & 5,5 & 0,055 & 94,5 & 1194,1 & 720,4 & 1196 & 474 & 0,40 & 2,511 & 2,606 & 3,7 & 17,3 & 78,9 \\
\hline $6-2 \mathrm{C}$ & 5,5 & 0,055 & 94,5 & 1212,1 & 736,5 & 1214,2 & 476 & 0,44 & 2,537 & 2,606 & 2,6 & 16,4 & 84,0 \\
\hline $7-2 \mathrm{C}$ & 5,5 & 0,055 & 94,5 & 1207,6 & 731,3 & 1209,8 & 476 & 0,46 & 2,524 & 2,606 & 3,2 & 16,9 & 81,3 \\
\hline médias & 5,5 & 0,055 & 94,5 & 1207,3 & 729,63 & 1209 & 477,643 & 0,360624 & 2,5185 & 2,606 & 3,4 & 17,0 & $\mathbf{8 0 , 3}$ \\
\hline $1-2 \mathrm{D}$ & 6,0 & 0,06 & 94 & 1202,0 & 727,0 & 1203,1 & 475 & 0,23 & 2,525 & 2,584 & 2,3 & 17,3 & 86,6 \\
\hline $2-2 \mathrm{D}$ & 6,0 & 0,06 & 94 & 1204,2 & 731,0 & 1205,5 & 473 & 0,27 & 2,538 & 2,584 & 1,8 & 16,9 & 89,3 \\
\hline $3-2 \mathrm{D}$ & 6,0 & 0,06 & 94 & 1218,1 & 739,2 & 1219,5 & 479 & 0,29 & 2,536 & 2,584 & 1,9 & 16,9 & 88,9 \\
\hline $4-2 \mathrm{D}$ & 6,0 & 0,06 & 94 & 1205,5 & 732,1 & 1206,7 & 473 & 0,25 & 2,540 & 2,584 & 1,7 & 16,8 & 89,8 \\
\hline $5-2 \mathrm{D}$ & 6,0 & 0,06 & 94 & 1207,9 & 732,2 & 1209 & 476 & 0,23 & 2,533 & 2,584 & 2,0 & 17,0 & 88,4 \\
\hline $6-2 \mathrm{D}$ & 6,0 & 0,06 & 94 & 1201,1 & 729,0 & 1202,5 & 472 & 0,30 & 2,537 & 2,584 & 1,9 & 16,9 & 89,0 \\
\hline $7-2 \mathrm{D}$ & 6,0 & 0,06 & 94 & 1218,9 & 740,0 & 1220,2 & 479 & 0,27 & 2,538 & 2,584 & 1,8 & 16,8 & 89,4 \\
\hline médias & 6,0 & 0,06 & 94 & 1208,2 & 732,93 & 1209,5 & 475,314 & 0,263777 & 2,5353 & 2,5845 & 1,9 & 16,9 & 88,8 \\
\hline $1-2 \mathrm{E}$ & 6,5 & 0,065 & 93,5 & 1205,3 & 730,8 & 1206,3 & 475 & 0,21 & 2,535 & 2,563 & 1,1 & 17,4 & 93,6 \\
\hline $2-2 E$ & 6,5 & 0,065 & 93,5 & 1202,9 & 731,5 & 1203,7 & 471 & 0,17 & 2,547 & 2,563 & 0,6 & 17,0 & 96,4 \\
\hline $3-2 \mathrm{E}$ & 6,5 & 0,065 & 93,5 & 1198,0 & 728,4 & 1199,1 & 470 & 0,23 & 2,545 & 2,563 & 0,7 & 17,1 & 95,9 \\
\hline $4-2 \mathrm{E}$ & 6,5 & 0,065 & 93,5 & 1215,0 & 736,2 & 1216 & 479 & 0,21 & 2,532 & 2,563 & 1,2 & 17,5 & 93,1 \\
\hline $5-2 \mathrm{E}$ & 6,5 & 0,065 & 93,5 & 1208,1 & 731,9 & 1209,4 & 476 & 0,27 & 2,530 & 2,563 & 1,3 & 17,5 & 92,6 \\
\hline $6-2 \mathrm{E}$ & 6,5 & 0,065 & 93,5 & 1193,5 & 723,2 & 1194,2 & 470 & 0,15 & 2,534 & 2,563 & 1,1 & 17,4 & 93,4 \\
\hline $7-2 \mathrm{E}$ & 6,5 & 0,065 & 93,5 & 1197,4 & 725,7 & 1199 & 472 & 0,34 & 2,530 & 2,563 & 1,3 & 17,6 & 92,6 \\
\hline médias & 6,5 & 0,065 & 93,5 & 1202,9 & 729,67 & 1204 & 473,214 & 0,225823 & 2,5362 & 2,5633 & 1,1 & 17,3 & 93,9 \\
\hline
\end{tabular}




\begin{tabular}{c|c|c|c|c}
\hline $\begin{array}{c}\text { Teor } \\
(\mathbf{\%})\end{array}$ & $\begin{array}{c}\text { Dap } \\
\left(\mathbf{g} / \mathbf{c m}^{3}\right)\end{array}$ & $\begin{array}{c}\text { Vv } \\
(\mathbf{\%})\end{array}$ & $\begin{array}{c}\text { VAM } \\
(\mathbf{\%})\end{array}$ & $\begin{array}{c}\text { RBV } \\
(\mathbf{\%})\end{array}$ \\
\hline 4,5 & 2,489 & 6,1 & 17,2 & 64,5 \\
\hline 5,0 & 2,505 & 4,7 & 17,0 & 72,6 \\
\hline 5,5 & 2,518 & 3,4 & 17,0 & 80,3 \\
\hline 6,0 & 2,535 & 1,9 & 16,9 & 88,8 \\
\hline 6,5 & 2,536 & 1,1 & 17,3 & 93,9 \\
\hline
\end{tabular}

Ensaio Marshall - 93-0-7
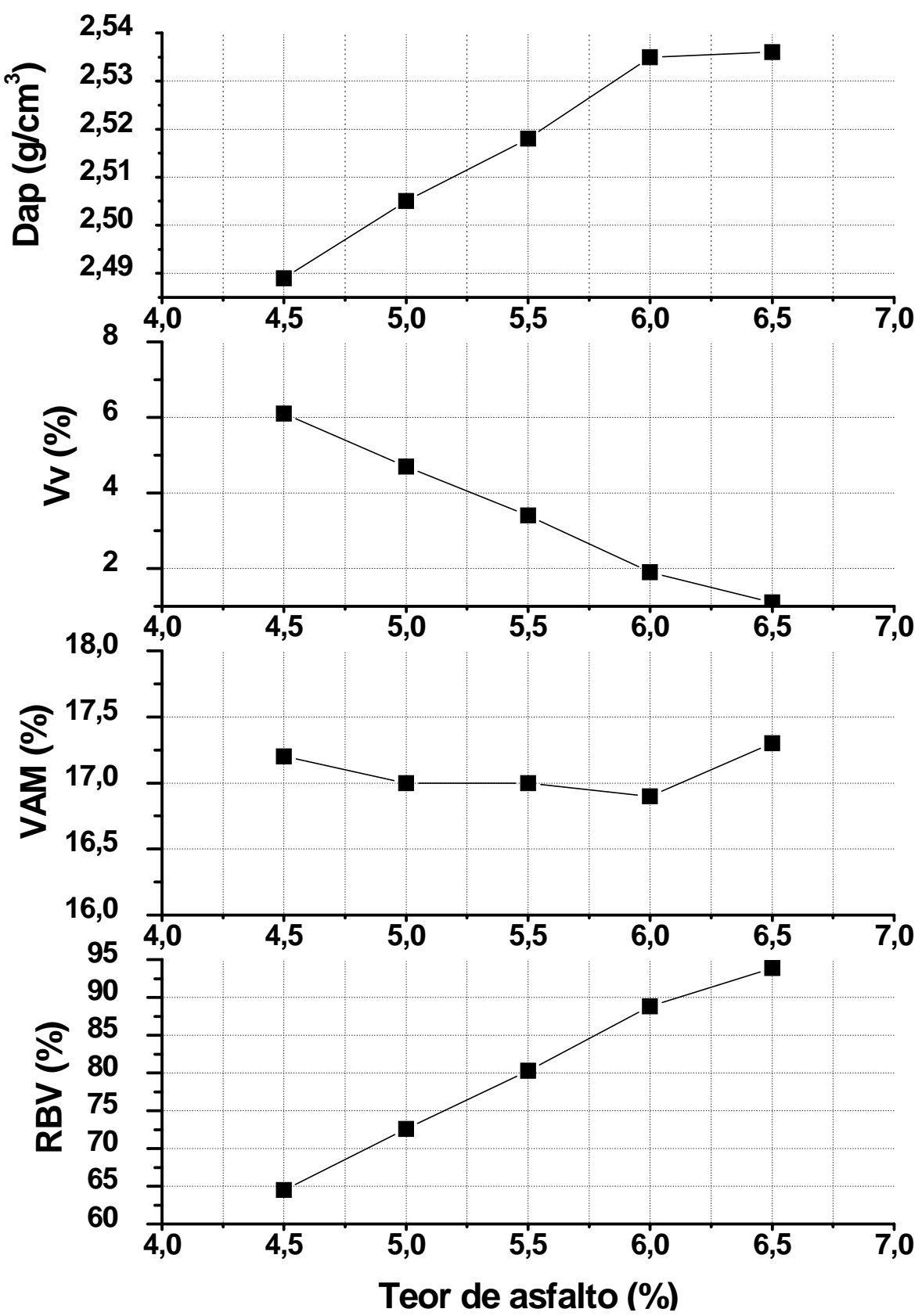

Figura A2: Parâmetros Marshall para mistura 93-0-7 
Planilha de dosagem Marshall - ligante asfáltico 3 (86-0-14)

$\begin{array}{ll}\text { dens. efetiva do agregado } & 2,869 \\ \text { dens. ponderada dos agregados } & 2,869 \\ \text { dens. do ligante asfáltico } & 1,020\end{array}$

Tabela A3: Parâmetros Marshall para mistura 86-0-14

\begin{tabular}{|c|c|c|c|c|c|c|c|c|c|c|c|c|c|}
\hline $\begin{array}{l}\text { número } \\
\text { do CP }\end{array}$ & $\begin{array}{c}\% \\
\text { ligante }\end{array}$ & $\begin{array}{c}\% \\
\text { ligante }\end{array}$ & $\begin{array}{c}\% \\
\text { agreg }\end{array}$ & $\begin{array}{c}\text { massa } \\
\text { ao ar }\end{array}$ & $\begin{array}{l}\text { massa } \\
\text { imersa }\end{array}$ & $\begin{array}{c}\text { massa } \\
\text { SSS }\end{array}$ & $\begin{array}{c}\text { volume } \\
\text { CP }\end{array}$ & $\begin{array}{l}\text { absorção } \\
\text { de água }\end{array}$ & $\begin{array}{l}\text { D } \\
\text { ap }\end{array}$ & $\begin{array}{l}\text { DMM } \\
\text { média }\end{array}$ & $\begin{array}{l}\text { Vv } \\
(\%)\end{array}$ & $\begin{array}{c}\text { VAM } \\
(\%)\end{array}$ & $\begin{array}{l}\text { RBV } \\
(\%)\end{array}$ \\
\hline $1-3 \mathrm{~A}$ & 4,5 & 0,045 & 95,5 & 1203,4 & 712,0 & 1210,8 & 491 & 1,48 & 2,413 & 2,653 & 9,1 & 19,7 & 54,0 \\
\hline $2-3 A$ & 4,5 & 0,045 & 95,5 & 1211,7 & 716,3 & 1219,0 & 495 & 1,45 & 2,410 & 2,653 & 9,1 & 19,8 & 53,8 \\
\hline $3-3 \mathrm{~A}$ & 4,5 & 0,045 & 95,5 & 1214,4 & 719,2 & 1221,9 & 495 & 1,49 & 2,416 & 2,653 & 8,9 & 19,6 & 54,4 \\
\hline $4-3 \mathrm{~A}$ & 4,5 & 0,045 & 95,5 & 1216,4 & 720,4 & 1223,5 & 496 & 1,41 & 2,418 & 2,653 & 8,9 & 19,5 & 54,6 \\
\hline $5-3 \mathrm{~A}$ & 4,5 & 0,045 & 95,5 & 1215,2 & 720,0 & 1222,9 & 495 & 1,53 & 2,416 & 2,653 & 8,9 & 19,6 & 54,5 \\
\hline $6-3 \mathrm{~A}$ & 4,5 & 0,045 & 95,5 & 1205,2 & 715,5 & 1212,4 & 490 & 1,45 & 2,425 & 2,653 & 8,6 & 19,3 & 55,5 \\
\hline $7-3 A$ & 4,5 & 0,045 & 95,5 & 1210,0 & 715,3 & 1217,8 & 495 & 1,55 & 2,408 & 2,653 & 9,2 & 19,8 & 53,5 \\
\hline médias & 4,5 & 0,045 & 95,5 & 1210,9 & 717,0 & 1218,3 & 494 & 1,48 & 2,415 & 2,653 & 9,0 & 19,6 & 54,3 \\
\hline $1-3 B$ & 5,0 & 0,05 & 95 & 1208,7 & 722,0 & 1213,1 & 487 & 0,90 & 2,461 & 2,631 & 6,4 & 18,5 & 65,2 \\
\hline $2-3 B$ & 5,0 & 0,05 & 95 & 1209,8 & 723,9 & 1214,4 & 486 & 0,94 & 2,466 & 2,631 & 6,2 & 18,3 & 65,9 \\
\hline $3-3 B$ & 5,0 & 0,05 & 95 & 1211,3 & 724,0 & 1216,0 & 487 & 0,96 & 2,462 & 2,631 & 6,4 & 18,5 & 65,3 \\
\hline $4-3 B$ & 5,0 & 0,05 & 95 & 1203,0 & 719,5 & 1208,5 & 484 & 1,12 & 2,460 & 2,631 & 6,5 & 18,5 & 65,0 \\
\hline $5-3 B$ & 5,0 & 0,05 & 95 & 1206,7 & 723,7 & 1211,7 & 483 & 1,02 & 2,473 & 2,631 & 6,0 & 18,1 & 66,9 \\
\hline $6-3 B$ & 5,0 & 0,05 & 95 & 1210,9 & 725,3 & 1216,1 & 486 & 1,06 & 2,467 & 2,631 & 6,2 & 18,3 & 66,1 \\
\hline $7-3 B$ & 5,0 & 0,05 & 95 & 1208,1 & 721,4 & 1212,9 & 487 & 0,98 & 2,458 & 2,631 & 6,6 & 18,6 & 64,7 \\
\hline médias & 5,0 & 0,05 & 95 & 1208,4 & 722,8 & 1213,2 & 486 & 1,00 & 2,464 & 2,631 & 6,3 & 18,4 & 65,6 \\
\hline $1-3 C$ & 5,5 & 0,055 & 94,5 & 1208,7 & 731,4 & 1212,2 & 477 & 0,73 & 2,514 & 2,609 & 3,6 & 17,2 & 78,8 \\
\hline $2-3 C$ & 5,5 & 0,055 & 94,5 & 1212,7 & 736,0 & 1215,9 & 477 & 0,67 & 2,527 & 2,609 & 3,1 & 16,8 & 81,2 \\
\hline $3-3 C$ & 5,5 & 0,055 & 94,5 & 1211,8 & 735,9 & 1214,8 & 476 & 0,63 & 2,530 & 2,609 & 3,0 & 16,7 & 81,9 \\
\hline $4-3 C$ & 5,5 & 0,055 & 94,5 & 1207,4 & 732,1 & 1211,4 & 475 & 0,83 & 2,519 & 2,609 & 3,4 & 17,0 & 79,8 \\
\hline $5-3 C$ & 5,5 & 0,055 & 94,5 & 1206,4 & 732,5 & 1209,8 & 474 & 0,71 & 2,528 & 2,609 & 3,1 & 16,7 & 81,4 \\
\hline
\end{tabular}




\begin{tabular}{|c|c|c|c|c|c|c|c|c|c|c|c|c|c|}
\hline $\begin{array}{c}\text { número } \\
\text { do CP }\end{array}$ & $\begin{array}{c}\% \\
\text { ligante } \\
\end{array}$ & $\begin{array}{c}\% \\
\text { ligante } \\
\end{array}$ & $\begin{array}{c}\% \\
\text { agreg }\end{array}$ & $\begin{array}{c}\text { massa } \\
\text { ao ar }\end{array}$ & $\begin{array}{c}\text { massa } \\
\text { imersa }\end{array}$ & $\begin{array}{c}\text { massa } \\
\text { SSS }\end{array}$ & $\begin{array}{c}\text { volume } \\
\text { CP }\end{array}$ & $\begin{array}{l}\text { absorção } \\
\text { de água }\end{array}$ & $\begin{array}{c}\text { D } \\
\text { ap }\end{array}$ & $\begin{array}{l}\text { DMM } \\
\text { média }\end{array}$ & $\begin{array}{l}\text { Vv } \\
(\%)\end{array}$ & $\begin{array}{c}\text { VAM } \\
(\%)\end{array}$ & $\begin{array}{c}\text { RBV } \\
(\%)\end{array}$ \\
\hline $6-3 C$ & 5,5 & 0,055 & 94,5 & 1210,9 & 732,7 & 1214,7 & 478 & 0,79 & 2,512 & 2,609 & 3,7 & 17,3 & 78,5 \\
\hline $7-3 \mathrm{C}$ & 5,5 & 0,055 & 94,5 & 1195,4 & 726,4 & 1198,6 & 469 & 0,68 & 2,532 & 2,609 & 3,0 & 16,6 & 82,1 \\
\hline médias & 5,5 & 0,055 & 94,5 & 1207,6 & 732,4 & 1211,1 & 475 & 0,72 & 2,523 & 2,609 & 3,3 & 16,9 & 80,5 \\
\hline 1-3D & 6,0 & 0,06 & 94 & 1193,7 & 726,6 & 1195,8 & 467 & 0,45 & 2,544 & 2,602 & 2,2 & 16,6 & 86,6 \\
\hline $2-3 D$ & 6,0 & 0,06 & 94 & 1201,5 & 729,8 & 1203,3 & 472 & 0,38 & 2,537 & 2,602 & 2,5 & 16,9 & 85,3 \\
\hline $3-3 D$ & 6,0 & 0,06 & 94 & 1202,4 & 731,8 & 1204,2 & 471 & 0,38 & 2,545 & 2,602 & 2,2 & 16,6 & 86,9 \\
\hline 4-3D & 6,0 & 0,06 & 94 & 1196,7 & 727,9 & 1198,4 & 469 & 0,36 & 2,543 & 2,602 & 2,2 & 16,7 & 86,5 \\
\hline $5-3 D$ & 6,0 & 0,06 & 94 & 1213,5 & 741,1 & 1215,6 & 472 & 0,44 & 2,557 & 2,602 & 1,7 & 16,2 & 89,4 \\
\hline $6-3 D$ & 6,0 & 0,06 & 94 & 1200,8 & 733,1 & 1202,8 & 468 & 0,43 & 2,557 & 2,602 & 1,7 & 16,2 & 89,2 \\
\hline $7-3 \mathrm{D}$ & 6,0 & 0,06 & 94 & 1203,9 & 733,4 & 1205,8 & 471 & 0,40 & 2,548 & 2,602 & 2,1 & 16,5 & 87,5 \\
\hline médias & 6,0 & 0,06 & 94 & 1201,8 & 732,0 & 1203,7 & 470 & 0,41 & 2,548 & 2,602 & 2,1 & 16,5 & 87,4 \\
\hline $1-3 E$ & 6,5 & 0,065 & 93,5 & 1211,0 & 736,7 & 1212,5 & 474 & 0,32 & 2,545 & 2,567 & 0,8 & 17,1 & 95,1 \\
\hline $2-3 E$ & 6,5 & 0,065 & 93,5 & 1219,0 & 741,3 & 1220,8 & 478 & 0,38 & 2,542 & 2,567 & 1,0 & 17,1 & 94,4 \\
\hline $3-3 E$ & 6,5 & 0,065 & 93,5 & 1217,4 & 741,9 & 1219,1 & 476 & 0,36 & 2,551 & 2,567 & 0,6 & 16,9 & 96,4 \\
\hline $4-3 E$ & 6,5 & 0,065 & 93,5 & 1212,6 & 738,4 & 1214,2 & 474 & 0,34 & 2,549 & 2,567 & 0,7 & 16,9 & 95,8 \\
\hline $5-3 E$ & 6,5 & 0,065 & 93,5 & 1205,1 & 734,6 & 1207,1 & 471 & 0,42 & 2,550 & 2,567 & 0,6 & 16,9 & 96,3 \\
\hline $6-3 E$ & 6,5 & 0,065 & 93,5 & 1189,3 & 724,2 & 1190,8 & 465 & 0,32 & 2,549 & 2,567 & 0,7 & 16,9 & 95,9 \\
\hline $7-3 E$ & 6,5 & 0,065 & 93,5 & 1202,6 & 731,3 & 1204,6 & 471 & 0,42 & 2,541 & 2,567 & 1,0 & 17,2 & 94,1 \\
\hline médias & 6,5 & 0,065 & 93,5 & 1208,1 & 735,5 & 1209,9 & 473 & 0,36 & 2,547 & 2,567 & 0,8 & 17,0 & 95,4 \\
\hline
\end{tabular}




\begin{tabular}{c|c|c|c|c}
\hline $\begin{array}{c}\text { Teor } \\
(\mathbf{\%})\end{array}$ & $\begin{array}{c}\text { Dap } \\
\left(\mathbf{g} / \mathbf{c m}^{3}\right)\end{array}$ & $\begin{array}{c}\text { Vv } \\
\mathbf{( \% )}\end{array}$ & $\begin{array}{c}\text { VAM } \\
(\mathbf{\%})\end{array}$ & $\begin{array}{c}\text { RBV } \\
(\mathbf{\%})\end{array}$ \\
\hline 4,5 & 2,415 & 9,0 & 19,6 & 54,3 \\
\hline 5,0 & 2,464 & 6,3 & 18,4 & 65,6 \\
\hline 5,5 & 2,523 & 3,3 & 16,9 & 80,5 \\
\hline 6,0 & 2,548 & 2,1 & 16,5 & 87,5 \\
\hline 6,5 & 2,547 & 0,8 & 17,0 & 95,4 \\
\hline
\end{tabular}

Ensaio Marshall - 86-0-14

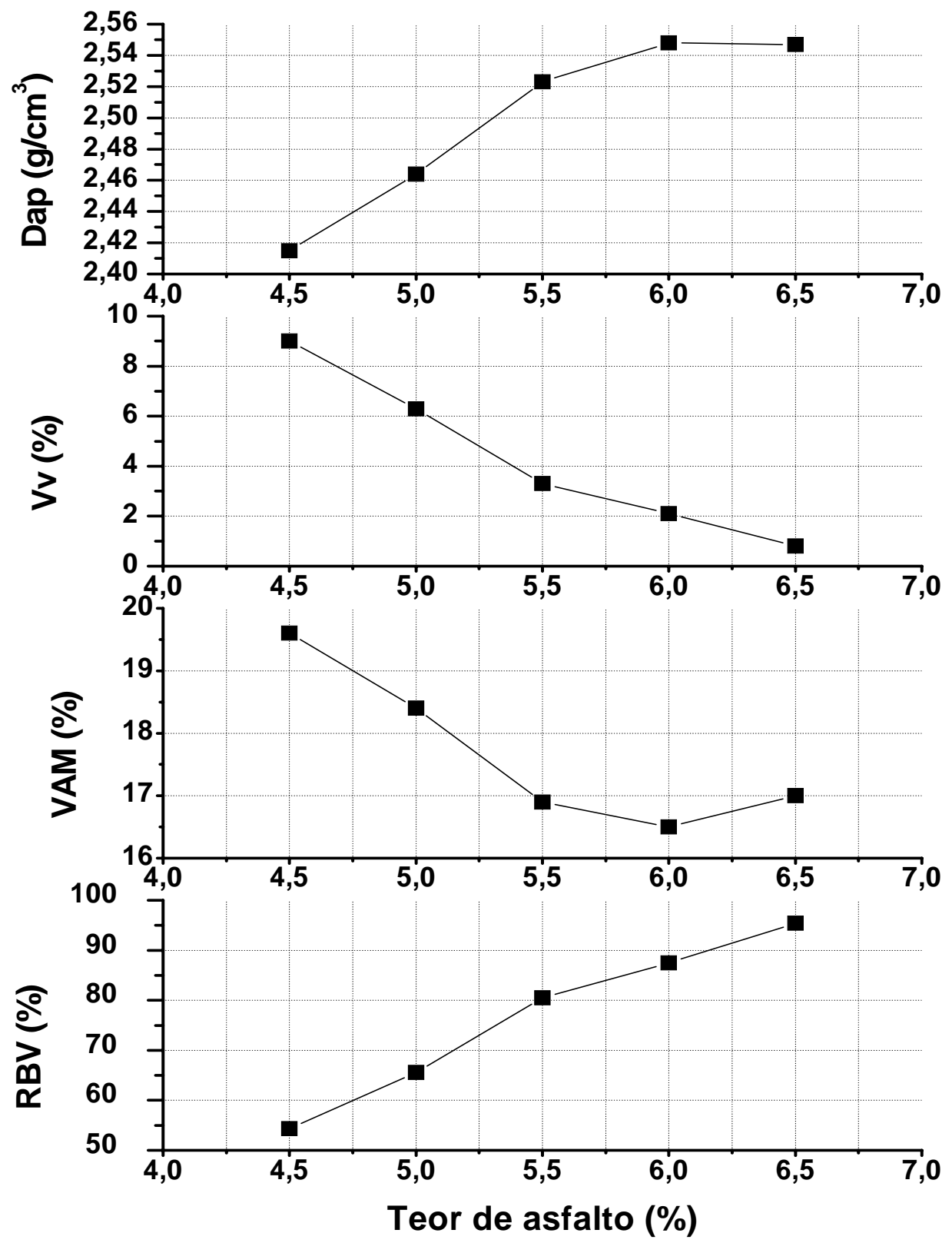

Figura A3: Parâmetros Marshall para mistura 86-0-14 
Planilha de dosagem Marshall - ligante asfáltico 4 (91-9-0)

dens. efetiva do agregado

dens. ponderada dos agregados

dens. do ligante asfáltico

$$
\begin{aligned}
& 2,867 \\
& 2,869 \\
& 1,026
\end{aligned}
$$

\begin{tabular}{|c|c|c|c|c|c|c|c|c|c|c|c|c|c|}
\hline $\begin{array}{c}\text { número } \\
\text { do CP }\end{array}$ & $\begin{array}{c}\% \% \\
\text { ligante } \\
\end{array}$ & $\begin{array}{c}\% \% \\
\text { ligante }\end{array}$ & $\begin{array}{c}\% \\
\text { agreg }\end{array}$ & $\begin{array}{c}\text { massa } \\
\text { ao ar }\end{array}$ & $\begin{array}{l}\text { massa } \\
\text { imersa }\end{array}$ & $\begin{array}{c}\text { massa } \\
\text { SSS }\end{array}$ & $\begin{array}{c}\text { volume } \\
\text { CP }\end{array}$ & $\begin{array}{c}\text { absorção } \\
\text { de água }\end{array}$ & $\begin{array}{c}\text { D } \\
\text { ap }\end{array}$ & $\begin{array}{l}\text { DMM } \\
\text { média }\end{array}$ & $\begin{array}{l}\text { Vv } \\
(\%)\end{array}$ & $\begin{array}{c}\text { VAM } \\
(\%)\end{array}$ & $\begin{array}{r}\text { RBV } \\
(\%)\end{array}$ \\
\hline $1-4 \mathrm{~A}$ & 4,5 & 0,045 & 95,5 & 1203,7 & 702,7 & 1205,1 & 501 & 0,28 & 2,396 & 2,652 & 9,7 & 20,2 & 52,3 \\
\hline $2-4 A$ & 4,5 & 0,045 & 95,5 & 1201,6 & 704,5 & 1203,6 & 497 & 0,40 & 2,408 & 2,652 & 9,2 & 19,9 & 53,5 \\
\hline $3-4 A$ & 4,5 & 0,045 & 95,5 & 1204,6 & 707,3 & 1206,6 & 497 & 0,40 & 2,413 & 2,652 & 9,0 & 19,7 & 54,1 \\
\hline $4-4 \mathrm{~A}$ & 4,5 & 0,045 & 95,5 & 1212,9 & 711,7 & 1214,5 & 501 & 0,32 & 2,412 & 2,652 & 9,1 & 19,7 & 54,1 \\
\hline $5-4 A$ & 4,5 & 0,045 & 95,5 & 1204,0 & 709,8 & 1206,1 & 494 & 0,42 & 2,426 & 2,652 & 8,5 & 19,2 & 55,7 \\
\hline $6-4 A$ & 4,5 & 0,045 & 95,5 & 1206,9 & 713,4 & 1208,3 & 494 & 0,28 & 2,439 & 2,652 & 8,1 & 18,8 & 57,2 \\
\hline $7-4 \mathrm{~A}$ & 4,5 & 0,045 & 95,5 & 1204,2 & 704,6 & 1205,9 & 500 & 0,34 & 2,402 & 2,652 & 9,4 & 20,0 & 52,9 \\
\hline médias & 4,5 & 0,045 & 95,5 & 1205,4 & 707,7 & 1207,2 & 498 & 0,35 & 2,414 & 2,652 & 9,0 & 19,7 & 54,2 \\
\hline $1-4 B$ & 5,0 & 0,05 & 95 & 1204,0 & 715,4 & 1205,2 & 489 & 0,24 & 2,458 & 2,630 & 6,6 & 18,6 & 64,8 \\
\hline $2-4 B$ & 5,0 & 0,05 & 95 & 1207,8 & 714,8 & 1208,7 & 493 & 0,18 & 2,445 & 2,630 & 7,0 & 19,0 & 63,0 \\
\hline $3-4 B$ & 5,0 & 0,05 & 95 & 1205,9 & 716,5 & 1206,7 & 489 & 0,16 & 2,460 & 2,630 & 6,5 & 18,5 & 65,0 \\
\hline 4-4B & 5,0 & 0,05 & 95 & 1211,0 & 718,7 & 1213,6 & 492 & 0,53 & 2,447 & 2,630 & 7,0 & 19,0 & 63,2 \\
\hline $5-4 B$ & 5,0 & 0,05 & 95 & 1201,1 & 716,2 & 1202,9 & 485 & 0,37 & 2,468 & 2,630 & 6,2 & 18,3 & 66,2 \\
\hline $6-4 B$ & 5,0 & 0,05 & 95 & 1202,9 & 720,1 & 1204,8 & 483 & 0,39 & 2,482 & 2,630 & 5,7 & 17,8 & 68,3 \\
\hline $7-4 B$ & 5,0 & 0,05 & 95 & 1207,8 & 722,5 & 1208,9 & 485 & 0,23 & 2,483 & 2,630 & 5,6 & 17,8 & 68,5 \\
\hline médias & 5,0 & 0,05 & 95 & 1205,8 & 717,7 & 1207,3 & 488 & 0,30 & 2,463 & 2,630 & 6,4 & 18,4 & 65,6 \\
\hline $1-4 \mathrm{C}$ & 5,5 & 0,055 & 94,5 & 1205,6 & 714,8 & 1206,9 & 491 & 0,26 & 2,450 & 2,609 & 6,1 & 19,3 & 68,4 \\
\hline $2-4 C$ & 5,5 & 0,055 & 94,5 & 1198,0 & 713,0 & 1198,7 & 485 & 0,14 & 2,467 & 2,609 & 5,5 & 18,8 & 70,9 \\
\hline $3-4 \mathrm{C}$ & 5,5 & 0,055 & 94,5 & 1199,1 & 712,2 & 1200,1 & 487 & 0,20 & 2,458 & 2,609 & 5,8 & 19,0 & 69,6 \\
\hline $4-4 \mathrm{C}$ & 5,5 & 0,055 & 94,5 & 1204,8 & 716,8 & 1205,8 & 488 & 0,20 & 2,464 & 2,609 & 5,6 & 18,8 & 70,5 \\
\hline $5-4 C$ & 5,5 & 0,055 & 94,5 & 1202,5 & 713,0 & 1203,5 & 490 & 0,20 & 2,452 & 2,609 & 6,0 & 19,2 & 68,7 \\
\hline
\end{tabular}

Tabela A4: Parâmetros Marshall para mistura 91-9-0 


\begin{tabular}{|c|c|c|c|c|c|c|c|c|c|c|c|c|c|}
\hline $\begin{array}{l}\text { número } \\
\text { do CP }\end{array}$ & $\begin{array}{c}\% \\
\text { ligante }\end{array}$ & $\begin{array}{c}\% \\
\text { ligante }\end{array}$ & $\begin{array}{c}\% \\
\text { agreg }\end{array}$ & $\begin{array}{c}\text { massa } \\
\text { ao ar }\end{array}$ & $\begin{array}{l}\text { massa } \\
\text { imersa }\end{array}$ & $\begin{array}{c}\text { massa } \\
\text { SSS }\end{array}$ & $\begin{array}{c}\text { volume } \\
\text { CP }\end{array}$ & $\begin{array}{c}\text { absorção } \\
\text { de água }\end{array}$ & $\begin{array}{l}\text { D } \\
\text { ap }\end{array}$ & $\begin{array}{l}\text { DMM } \\
\text { média }\end{array}$ & $\begin{array}{l}\text { Vv } \\
(\%)\end{array}$ & $\begin{array}{c}\text { VAM } \\
(\%)\end{array}$ & $\begin{array}{l}\text { RBV } \\
\text { (\%) }\end{array}$ \\
\hline $6-4 \mathrm{C}$ & 5,5 & 0,055 & 94,5 & 1210,6 & 720,7 & 1211,9 & 490 & 0,26 & 2,465 & 2,609 & 5,5 & 18,8 & 70,6 \\
\hline $7-4 C$ & 5,5 & 0,055 & 94,5 & 1200,1 & 713,9 & 1201,2 & 486 & 0,23 & 2,463 & 2,609 & 5,6 & 18,9 & 70,3 \\
\hline médias & 5,5 & 0,055 & 94,5 & 1203 & 714,9 & 1204 & 488 & 0,22 & 2,460 & 2,609 & 5,7 & 19,0 & 69,8 \\
\hline $1-4 \mathrm{D}$ & 6,0 & 0,06 & 94 & 1206,8 & 728,6 & 1207,4 & 478 & 0,13 & 2,520 & 2,588 & 2,6 & 17,4 & 85,1 \\
\hline $2-4 \mathrm{D}$ & 6,0 & 0,06 & 94 & 1211,8 & 733,2 & 1212,2 & 479 & 0,08 & 2,530 & 2,588 & 2,2 & 17,1 & 86,9 \\
\hline $3-4 \mathrm{D}$ & 6,0 & 0,06 & 94 & 1204,7 & 726,2 & 1205,1 & 479 & 0,08 & 2,516 & 2,588 & 2,8 & 17,6 & 84,1 \\
\hline 4-4D & 6,0 & 0,06 & 94 & 1203,5 & 724,9 & 1204,2 & 479 & 0,15 & 2,511 & 2,588 & 3,0 & 17,7 & 83,2 \\
\hline $5-4 \mathrm{D}$ & 6,0 & 0,06 & 94 & 1196,7 & 722,6 & 1197,3 & 474 & 0,13 & 2,521 & 2,588 & 2,6 & 17,4 & 85,1 \\
\hline $6-4 \mathrm{D}$ & 6,0 & 0,06 & 94 & 1203,5 & 727,6 & 1204,1 & 476 & 0,13 & 2,526 & 2,588 & 2,4 & 17,2 & 86,1 \\
\hline $7-4 \mathrm{D}$ & 6,0 & 0,06 & 94 & 1211,7 & 732,4 & 1212,5 & 479 & 0,17 & 2,524 & 2,588 & 2,5 & 17,3 & 85,7 \\
\hline médias & 6,0 & 0,06 & 94 & 1205,5 & 727,9 & 1206,1 & 478 & 0,12 & 2,521 & 2,588 & 2,6 & 17,4 & 85,2 \\
\hline $1-4 \mathrm{E}$ & 6,5 & 0,065 & 93,5 & 1210,2 & 724,0 & 1211 & 486 & 0,16 & 2,485 & 2,567 & 3,2 & 19,0 & 83,2 \\
\hline $2-4 \mathrm{E}$ & 6,5 & 0,065 & 93,5 & 1203,5 & 717,4 & 1204 & 486 & 0,10 & 2,473 & 2,567 & 3,7 & 19,4 & 81,2 \\
\hline $3-4 \mathrm{E}$ & 6,5 & 0,065 & 93,5 & 1212,9 & 726,3 & 1213,9 & 487 & 0,21 & 2,487 & 2,567 & 3,1 & 18,9 & 83,6 \\
\hline $4-4 \mathrm{E}$ & 6,5 & 0,065 & 93,5 & 1201,6 & 717,6 & 1202,8 & 484 & 0,25 & 2,477 & 2,567 & 3,5 & 19,3 & 81,7 \\
\hline $5-4 E$ & 6,5 & 0,065 & 93,5 & 1206,1 & 719,8 & 1207 & 486 & 0,18 & 2,476 & 2,567 & 3,6 & 19,3 & 81,6 \\
\hline $6-4 E$ & 6,5 & 0,065 & 93,5 & 1205,2 & 718,8 & 1205,8 & 486 & 0,12 & 2,475 & 2,567 & 3,6 & 19,3 & 81,4 \\
\hline $7-4 \mathrm{E}$ & 6,5 & 0,065 & 93,5 & 1204,9 & 719,5 & 1206,1 & 485 & 0,25 & 2,476 & 2,567 & 3,5 & 19,3 & 81,7 \\
\hline médias & 6,5 & 0,065 & 93,5 & 1206,3 & 720,5 & 1207,2 & 486 & 0,18 & 2,478 & 2,567 & 3,5 & 19,2 & 82,0 \\
\hline
\end{tabular}




\begin{tabular}{c|c|c|c|c}
\hline $\begin{array}{c}\text { teor } \\
\mathbf{( \% )}\end{array}$ & $\begin{array}{c}\text { Dap } \\
\left(\mathbf{g} / \mathbf{c m}^{3}\right)\end{array}$ & $\begin{array}{c}\text { Vv } \\
\mathbf{( \% )}\end{array}$ & $\begin{array}{c}\text { VAM } \\
(\mathbf{\%})\end{array}$ & $\begin{array}{c}\text { RBV } \\
(\mathbf{\%})\end{array}$ \\
\hline 4,5 & 2,414 & 9,0 & 19,7 & 54,2 \\
\hline 5,0 & 2,463 & 6,4 & 18,4 & 65,6 \\
\hline 5,5 & 2,460 & 5,7 & 19,0 & 69,8 \\
\hline 6,0 & 2,521 & 2,6 & 17,4 & 85,2 \\
\hline 6,5 & 2,478 & 3,5 & 19,2 & 82,0 \\
\hline
\end{tabular}

\section{Ensaio Marshall - 91-9-0}

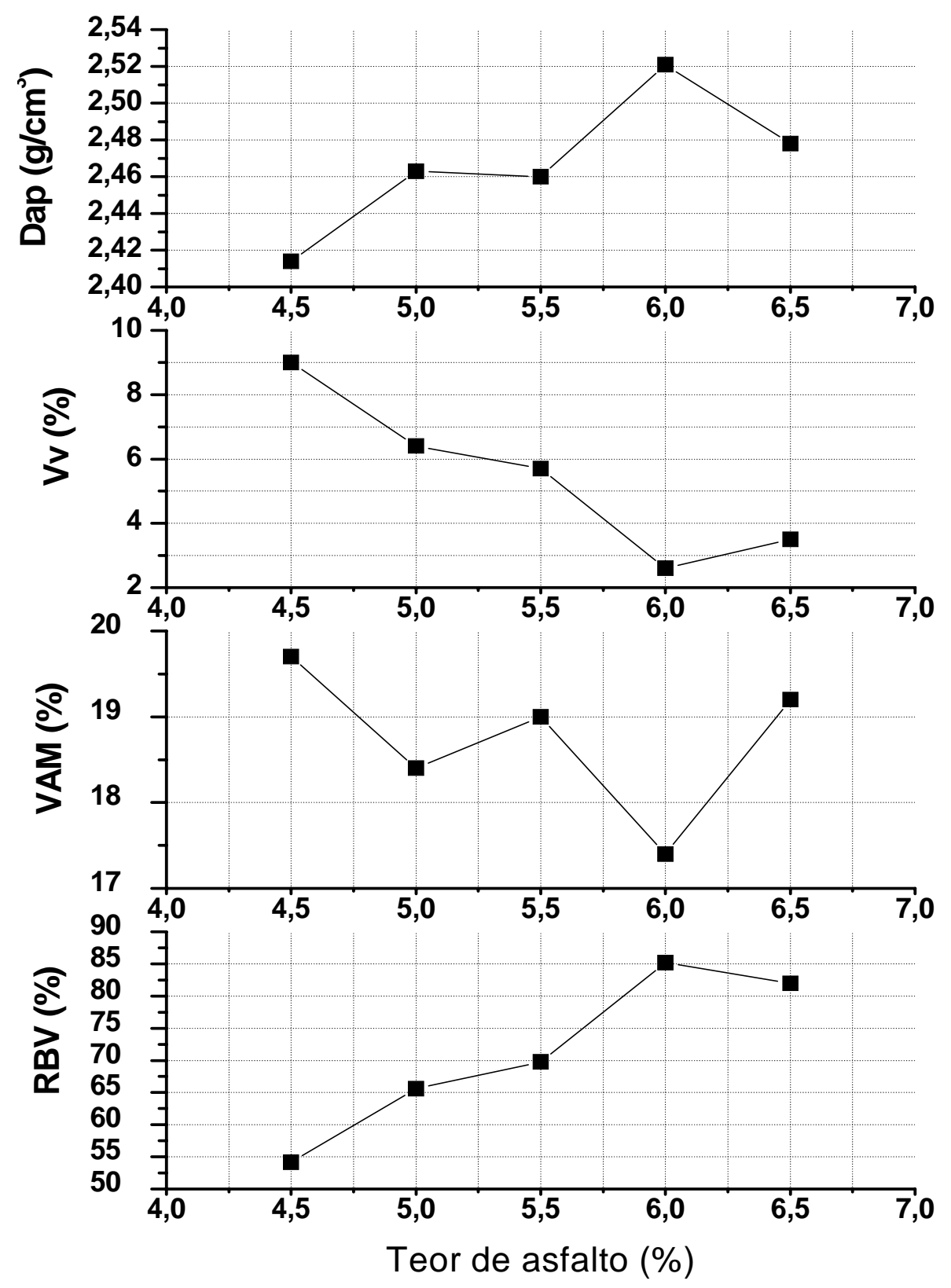

Figura A4: Parâmetros Marshall para mistura 91-9-0 
Planilha de dosagem Marshall - ligante asfáltico 5 (77-9-14)

dens. efetiva do agregado

dens. ponderada dos agregados

dens. do ligante asfáltico
2,867

2,869

1,038

Tabela A5: Parâmetros Marshall para mistura 77-9-14

\begin{tabular}{|c|c|c|c|c|c|c|c|c|c|c|c|c|c|}
\hline $\begin{array}{c}\text { número } \\
\text { do CP }\end{array}$ & $\begin{array}{c}\% \\
\text { ligante }\end{array}$ & $\begin{array}{c}\% \\
\text { ligante }\end{array}$ & $\begin{array}{c}\% \\
\text { agreg }\end{array}$ & $\begin{array}{c}\text { massa } \\
\text { ao ar }\end{array}$ & $\begin{array}{c}\text { massa } \\
\text { imersa }\end{array}$ & $\begin{array}{c}\text { massa } \\
\text { SSS }\end{array}$ & $\begin{array}{c}\text { volume } \\
\text { CP }\end{array}$ & $\begin{array}{c}\text { absorção } \\
\text { de água }\end{array}$ & $\begin{array}{l}\text { D } \\
\text { ap }\end{array}$ & $\begin{array}{l}\text { DMM } \\
\text { média }\end{array}$ & $\begin{array}{r}\mathrm{Vv} \\
(\%)\end{array}$ & $\begin{array}{l}\text { VAM } \\
(\%)\end{array}$ & $\begin{array}{l}\text { RBV } \\
(\%)\end{array}$ \\
\hline $1-5 \mathrm{~A}$ & 4,5 & 0,045 & 95,5 & 1206,4 & 719,7 & 1207,8 & 487 & 0,29 & 2,472 & 2,657 & 7,0 & 17,7 & 60,7 \\
\hline $2-5 \mathrm{~A}$ & 4,5 & 0,045 & 95,5 & 1207,0 & 718,8 & 1208,0 & 488 & 0,20 & 2,467 & 2,657 & 7,1 & 17,9 & 60,1 \\
\hline $3-5 \mathrm{~A}$ & 4,5 & 0,045 & 95,5 & 1210,6 & 722,8 & 1211,9 & 488 & 0,27 & 2,475 & 2,657 & 6,8 & 17,6 & 61,2 \\
\hline $4-5 \mathrm{~A}$ & 4,5 & 0,045 & 95,5 & 1207,6 & 720,8 & 1208,7 & 487 & 0,23 & 2,475 & 2,657 & 6,8 & 17,6 & 61,2 \\
\hline $5-5 A$ & 4,5 & 0,045 & 95,5 & 1210,3 & 723,9 & 1211,6 & 486 & 0,27 & 2,482 & 2,657 & 6,6 & 17,4 & 62,1 \\
\hline $6-5 \mathrm{~A}$ & 4,5 & 0,045 & 95,5 & 1204,9 & 719,5 & 1207,5 & 485 & 0,53 & 2,469 & 2,657 & 7,1 & 17,8 & 60,3 \\
\hline $7-5 \mathrm{~A}$ & 4,5 & 0,045 & 95,5 & 1227,0 & 730,2 & 1229,9 & 497 & 0,58 & 2,455 & 2,657 & 7,6 & 18,3 & 58,5 \\
\hline médias & 4,5 & 0,045 & 95,5 & 1210,54 & 722,2 & 1212 & 488 & 0,34 & 2,471 & 2,657 & 7,0 & 17,8 & 60,6 \\
\hline $1-5 B$ & 5,0 & 0,050 & 95,0 & 1211,6 & 726,6 & 1212,7 & 485 & 0,23 & 2,492 & 2,635 & 5,4 & 17,5 & 69,0 \\
\hline $2-5 B$ & 5,0 & 0,050 & 95,0 & 1203,8 & 721,2 & 1205,0 & 483 & 0,25 & 2,488 & 2,635 & 5,6 & 17,6 & 68,3 \\
\hline $3-5 B$ & 5,0 & 0,050 & 95,0 & 1215,0 & 730,4 & 1215,7 & 485 & 0,14 & 2,504 & 2,635 & 5,0 & 17,1 & 70,8 \\
\hline $4-5 B$ & 5,0 & 0,050 & 95,0 & 1178,6 & 708,2 & 1180,0 & 470 & 0,30 & 2,498 & 2,635 & 5,2 & 17,3 & 69,9 \\
\hline $5-5 B$ & 5,0 & 0,050 & 95,0 & 1208,6 & 727,5 & 1209,7 & 481 & 0,23 & 2,506 & 2,635 & 4,9 & 17,0 & 71,3 \\
\hline $6-5 B$ & 5,0 & 0,050 & 95,0 & 1204,9 & 723,4 & 1205,8 & 482 & 0,19 & 2,498 & 2,635 & 5,2 & 17,3 & 69,8 \\
\hline $7-5 B$ & 5,0 & 0,050 & 95,0 & 1206,2 & 726,2 & 1207,2 & 480 & 0,21 & 2,508 & 2,635 & 4,8 & 17,0 & 71,5 \\
\hline médias & 5,0 & 0,050 & 95,0 & 1204,1 & 723,4 & 1205 & 481 & 0,22 & 2,499 & 2,635 & 5,2 & 17,2 & 70,1 \\
\hline $1-5 \mathrm{C}$ & 5,5 & 0,055 & 94,5 & 1216,9 & 731,4 & 1217,7 & 486 & 0,16 & 2,502 & 2,614 & 4,3 & 17,6 & 75,7 \\
\hline
\end{tabular}




\begin{tabular}{|c|c|c|c|c|c|c|c|c|c|c|c|c|c|}
\hline $\begin{array}{c}\text { número } \\
\text { do CP }\end{array}$ & $\begin{array}{c}\% \\
\text { ligante }\end{array}$ & $\begin{array}{c}\% \\
\text { ligante }\end{array}$ & $\begin{array}{c}\% \\
\text { agreg }\end{array}$ & $\begin{array}{c}\text { massa } \\
\text { ao ar }\end{array}$ & $\begin{array}{l}\text { massa } \\
\text { imersa }\end{array}$ & $\begin{array}{c}\text { massa } \\
\text { SSS }\end{array}$ & $\begin{array}{c}\text { volume } \\
\text { CP }\end{array}$ & $\begin{array}{c}\text { absorção } \\
\text { de água }\end{array}$ & $\begin{array}{c}\text { D } \\
\text { ap }\end{array}$ & $\begin{array}{l}\text { DMM } \\
\text { média }\end{array}$ & $\begin{array}{l}\mathrm{Vv} \\
(\%)\end{array}$ & $\begin{array}{l}\text { VAM } \\
(\%)\end{array}$ & $\begin{array}{l}\text { RBV } \\
(\%)\end{array}$ \\
\hline $2-5 \mathrm{C}$ & 5,5 & 0,055 & 94,5 & 1199,2 & 721,6 & 1199,8 & 478 & 0,13 & 2,508 & 2,614 & 4,1 & 17,4 & 76,6 \\
\hline $3-5 \mathrm{C}$ & 5,5 & 0,055 & 94,5 & 1206,4 & 723,2 & 1207,1 & 483 & 0,14 & 2,493 & 2,614 & 4,6 & 17,9 & 74,1 \\
\hline $4-5 \mathrm{C}$ & 5,5 & 0,055 & 94,5 & 1207,0 & 722,6 & 1203,0 & 484 & $-0,83$ & 2,512 & 2,614 & 3,9 & 17,2 & 77,5 \\
\hline $5-5 \mathrm{C}$ & 5,5 & 0,055 & 94,5 & 1206,2 & 724,3 & 1208,0 & 482 & 0,37 & 2,494 & 2,614 & 4,6 & 17,9 & 74,2 \\
\hline $6-5 \mathrm{C}$ & 5,5 & 0,055 & 94,5 & 1206,3 & 727,1 & 1206,8 & 479 & 0,10 & 2,515 & 2,614 & 3,8 & 17,2 & 77,9 \\
\hline $7-5 \mathrm{C}$ & 5,5 & 0,055 & 94,5 & 1208,2 & 727,0 & 1209,7 & 481 & 0,31 & 2,503 & 2,614 & 4,2 & 17,6 & 75,8 \\
\hline médias & 5,5 & 0,055 & 94,5 & 1207,17 & 725,3 & 1207 & 482 & 0,06 & 2,504 & 2,614 & 4,2 & 17,5 & 76,0 \\
\hline $1-5 \mathrm{D}$ & 6,0 & 0,060 & 94,0 & 1210,4 & 732,4 & 1211,0 & 478 & 0,13 & 2,529 & 2,593 & 2,5 & 17,1 & 85,5 \\
\hline $2-5 \mathrm{D}$ & 6,0 & 0,060 & 94,0 & 1204,5 & 729,7 & 1205,0 & 475 & 0,11 & 2,534 & 2,593 & 2,3 & 17,0 & 86,6 \\
\hline $3-5 \mathrm{D}$ & 6,0 & 0,060 & 94,0 & 1204,1 & 731,2 & 1204,6 & 473 & 0,11 & 2,544 & 2,593 & 1,9 & 16,7 & 88,5 \\
\hline $4-5 \mathrm{D}$ & 6,0 & 0,060 & 94,0 & 1205,4 & 728,7 & 1205,9 & 477 & 0,10 & 2,526 & 2,593 & 2,6 & 17,2 & 84,9 \\
\hline $5-5 \mathrm{D}$ & 6,0 & 0,060 & 94,0 & 1207,4 & 731,6 & 1208,1 & 476 & 0,15 & 2,534 & 2,593 & 2,3 & 17,0 & 86,5 \\
\hline $6-5 \mathrm{D}$ & 6,0 & 0,060 & 94,0 & 1208,4 & 731,2 & 1208,9 & 477 & 0,10 & 2,530 & 2,593 & 2,5 & 17,1 & 85,7 \\
\hline $7-5 \mathrm{D}$ & 6,0 & 0,060 & 94,0 & 1204,8 & 727,4 & 1205,1 & 477 & 0,06 & 2,522 & 2,593 & 2,7 & 17,4 & 84,2 \\
\hline médias & 6,0 & 0,060 & 94,0 & 1206,43 & 730,3 & 1207 & 476 & $\mathbf{0 , 1 1}$ & 2,531 & 2,593 & 2,4 & 17,1 & 86,0 \\
\hline $1-5 \mathrm{E}$ & 6,5 & 0,065 & 93,5 & 1214,2 & 735,1 & 1214,6 & 479 & 0,08 & 2,532 & 2,573 & 1,6 & 17,5 & 91,0 \\
\hline $2-5 \mathrm{E}$ & 6,5 & 0,065 & 93,5 & 1202,5 & 724,8 & 1202,9 & 478 & 0,08 & 2,515 & 2,573 & 2,2 & 18,0 & 87,6 \\
\hline $3-5 \mathrm{E}$ & 6,5 & 0,065 & 93,5 & 1208,9 & 729,1 & 1209,6 & 480 & 0,15 & 2,516 & 2,573 & 2,2 & 18,0 & 87,7 \\
\hline $4-5 \mathrm{E}$ & 6,5 & 0,065 & 93,5 & 1200,7 & 722,7 & 1201,4 & 478 & 0,15 & 2,508 & 2,573 & 2,5 & 18,3 & 86,3 \\
\hline $5-5 \mathrm{E}$ & 6,5 & 0,065 & 93,5 & 1213,0 & 731,9 & 1214,7 & 481 & 0,35 & 2,512 & 2,573 & 2,3 & 18,1 & 87,1 \\
\hline $6-5 \mathrm{E}$ & 6,5 & 0,065 & 93,5 & 1202,5 & 725,4 & 1203,2 & 477 & 0,15 & 2,517 & 2,573 & 2,2 & 18,0 & 87,9 \\
\hline $7-5 \mathrm{E}$ & 6,5 & 0,065 & 93,5 & 1211,9 & 729,2 & 1212,4 & 483 & 0,10 & 2,508 & 2,573 & 2,5 & 18,3 & 86,2 \\
\hline médias & 6,5 & 0,065 & 93,5 & 1207,67 & 728,3 & 1208 & 479 & 0,15 & 2,516 & 2,573 & 2,2 & 18,0 & 87,7 \\
\hline
\end{tabular}




\begin{tabular}{c|c|c|c|c}
\hline $\begin{array}{c}\text { Teor } \\
(\%)\end{array}$ & $\begin{array}{c}\text { Dap } \\
\left(\mathbf{g} / \mathbf{c m}^{3}\right)\end{array}$ & $\begin{array}{c}\text { Vv } \\
(\mathbf{\%})\end{array}$ & $\begin{array}{c}\text { VAM } \\
\mathbf{( \% )}\end{array}$ & $\begin{array}{c}\text { RBV } \\
\mathbf{( \% )}\end{array}$ \\
\hline 4,5 & 2,471 & 7,0 & 17,8 & 60,6 \\
\hline 5,0 & 2,499 & 5,2 & 17,2 & 70,1 \\
\hline 5,5 & 2,504 & 4,2 & 17,5 & 76,0 \\
\hline 6,0 & 2,531 & 2,4 & 17,1 & 86,0 \\
\hline 6,5 & 2,516 & 2,2 & 18,0 & 87,7 \\
\hline
\end{tabular}

Ensaio Marshall - 77-9-14

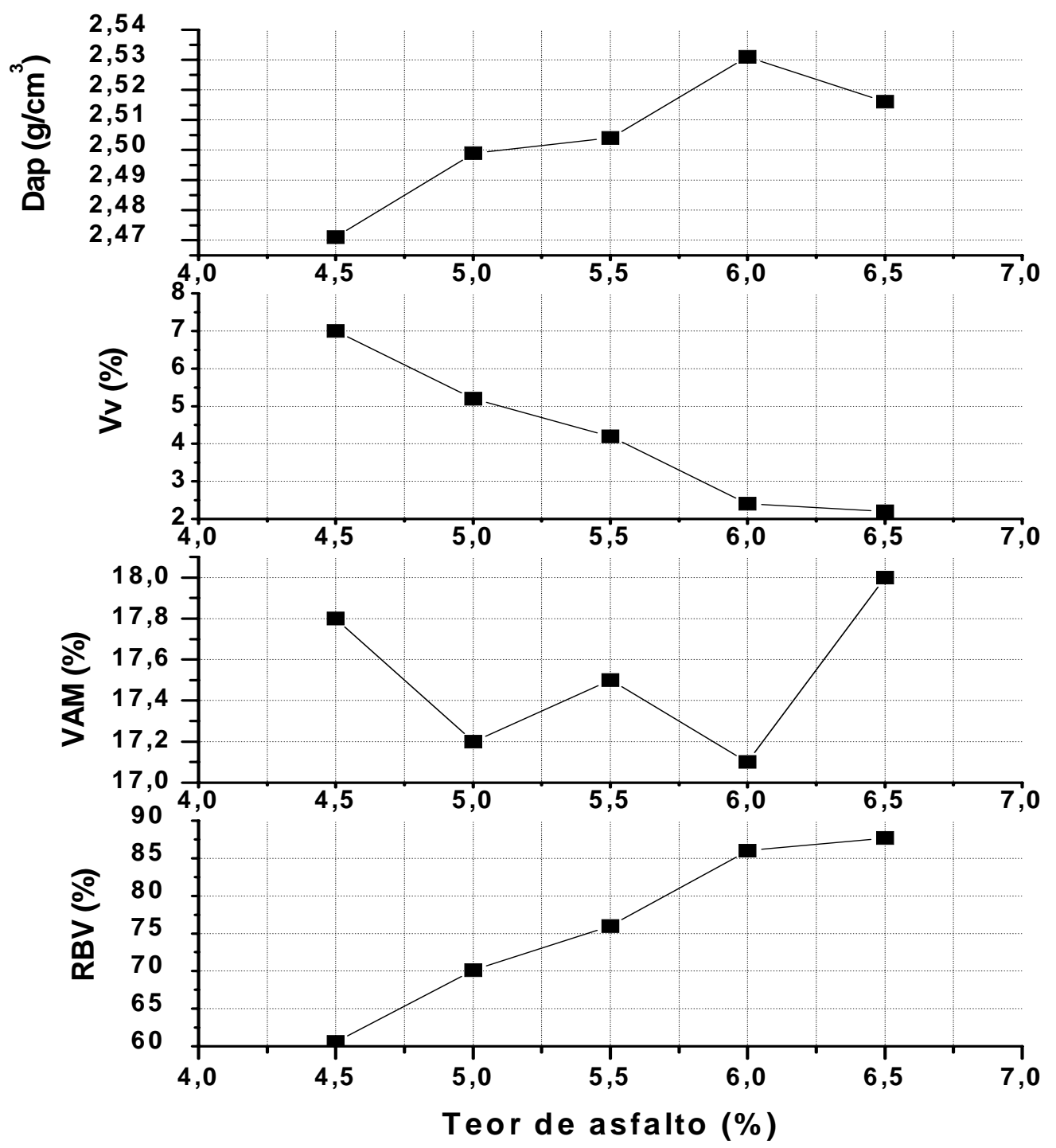

Figura A5: Parâmetros Marshall para mistura 77-9-14 
Planilha de dosagem Marshall - ligante asfáltico 6 (82-18-0)

dens. efetiva do agregado $\quad 2,869$

dens. ponderada dos agregados $\quad 2,869$

dens. do ligante asfáltico $\quad 1,041$

Tabela A6: Parâmetros Marshall para mistura 82-18-0

\begin{tabular}{|c|c|c|c|c|c|c|c|c|c|c|c|c|c|}
\hline $\begin{array}{c}\text { número } \\
\text { do CP }\end{array}$ & $\begin{array}{c}\% \\
\text { ligante }\end{array}$ & $\begin{array}{c}\% \\
\text { ligante }\end{array}$ & $\begin{array}{c}\% \\
\text { agreg } \\
\end{array}$ & $\begin{array}{c}\text { massa } \\
\text { ao ar }\end{array}$ & $\begin{array}{c}\text { massa } \\
\text { imersa }\end{array}$ & $\begin{array}{c}\text { massa } \\
\text { SSS }\end{array}$ & $\begin{array}{c}\text { volume } \\
\text { CP } \\
\end{array}$ & $\begin{array}{c}\text { absorção } \\
\text { de água }\end{array}$ & $\begin{array}{c}\text { D } \\
\text { ap }\end{array}$ & $\begin{array}{l}\text { DMM } \\
\text { média }\end{array}$ & $\begin{array}{l}\mathrm{Vv} \\
(\%)\end{array}$ & $\begin{array}{c}\text { VAM } \\
(\%)\end{array}$ & $\begin{array}{r}\text { RBV } \\
(\%)\end{array}$ \\
\hline $1-6 \mathrm{~A}$ & 4,5 & 0,045 & 95,5 & 1206,4 & 714,3 & 1208,0 & 492 & 0,32 & 2,444 & 2,659 & 8,1 & 18,7 & 56,7 \\
\hline $2-6 A$ & 4,5 & 0,045 & 95,5 & 1216,1 & 720,4 & 1217,5 & 496 & 0,28 & 2,446 & 2,659 & 8,0 & 18,6 & 57,0 \\
\hline $3-6 \mathrm{~A}$ & 4,5 & 0,045 & 95,5 & 1215,9 & 727,5 & 1227,3 & 488 & 2,28 & 2,433 & 2,659 & 8,5 & 19,0 & 55,3 \\
\hline $4-6 \mathrm{~A}$ & 4,5 & 0,045 & 95,5 & 1217,7 & 724,4 & 1219,8 & 493 & 0,42 & 2,458 & 2,659 & 7,5 & 18,2 & 58,5 \\
\hline $5-6 \mathrm{~A}$ & 4,5 & 0,045 & 95,5 & 1232,1 & 731,8 & 1233,5 & 500 & 0,28 & 2,456 & 2,659 & 7,6 & 18,3 & 58,2 \\
\hline $6-6 \mathrm{~A}$ & 4,5 & 0,045 & 95,5 & 1229,3 & 730,4 & 1231,3 & 499 & 0,40 & 2,454 & 2,659 & 7,7 & 18,3 & 58,0 \\
\hline $7-6 \mathrm{~A}$ & 4,5 & 0,045 & 95,5 & 1220,4 & 724,2 & 1222,4 & 496 & 0,40 & 2,450 & 2,659 & 7,9 & 18,5 & 57,4 \\
\hline médias & 4,5 & 0,045 & 95,5 & 1219,7 & 724,71 & 1222,8 & 495 & 0,63 & 2,449 & 2,659 & 7,9 & 18,5 & 57,3 \\
\hline $1-6 \mathrm{~B}$ & 5,0 & 0,05 & 95 & 1222,2 & 729,4 & 1223,8 & 493 & 0,32 & 2,472 & 2,637 & 6,3 & 18,1 & 65,5 \\
\hline $2-6 B$ & 5,0 & 0,05 & 95 & 1215,7 & 723,3 & 1216,9 & 492 & 0,24 & 2,463 & 2,637 & 6,6 & 18,4 & 64,2 \\
\hline $3-6 \mathrm{~B}$ & 5,0 & 0,05 & 95 & 1207,4 & 717,0 & 1208,7 & 490 & 0,26 & 2,456 & 2,637 & 6,9 & 18,7 & 63,2 \\
\hline $4-6 \mathrm{~B}$ & 5,0 & 0,05 & 95 & 1235,7 & 731,7 & 1238,1 & 504 & 0,47 & 2,440 & 2,637 & 7,5 & 19,2 & 61,1 \\
\hline $5-6 \mathrm{~B}$ & 5,0 & 0,05 & 95 & 1228,8 & 731,2 & 1230,4 & 498 & 0,32 & 2,462 & 2,637 & 6,7 & 18,5 & 64,0 \\
\hline 6-6B & 5,0 & 0,05 & 95 & 1226,1 & 732,4 & 1227,4 & 494 & 0,26 & 2,477 & 2,637 & 6,1 & 18,0 & 66,2 \\
\hline $7-6 B$ & 5,0 & 0,05 & 95 & 1220,8 & 724,3 & 1221,8 & 497 & 0,20 & 2,454 & 2,637 & 6,9 & 18,7 & 62,9 \\
\hline médias & 5,0 & 0,05 & 95 & 1222,4 & 727,04 & 1223,9 & 495 & 0,30 & 2,460 & 2,637 & 6,7 & 18,5 & 63,9 \\
\hline $1-6 \mathrm{C}$ & 5,5 & 0,055 & 94,5 & 1236,9 & 739,9 & 1237,6 & 497 & 0,14 & 2,485 & 2,616 & 5,0 & 18,1 & 72,4 \\
\hline
\end{tabular}




\begin{tabular}{|c|c|c|c|c|c|c|c|c|c|c|c|c|c|}
\hline $\begin{array}{l}\text { número } \\
\text { do } \mathrm{CP}\end{array}$ & $\begin{array}{c}\% \\
\text { ligante }\end{array}$ & $\begin{array}{c}\% \\
\text { ligante } \\
\end{array}$ & $\begin{array}{c}\% \\
\text { agreg }\end{array}$ & $\begin{array}{c}\text { massa } \\
\text { ao ar }\end{array}$ & $\begin{array}{l}\text { massa } \\
\text { imersa }\end{array}$ & $\begin{array}{c}\text { massa } \\
\text { SSS }\end{array}$ & $\begin{array}{c}\text { volume } \\
\text { CP } \\
\end{array}$ & $\begin{array}{c}\text { absorção } \\
\text { de água }\end{array}$ & $\begin{array}{c}\text { D } \\
\text { ap }\end{array}$ & $\begin{array}{l}\text { DMM } \\
\text { média }\end{array}$ & $\begin{array}{l}\text { Vv } \\
(\%)\end{array}$ & $\begin{array}{c}\text { VAM } \\
(\%)\end{array}$ & $\begin{array}{l}\text { RBV } \\
(\%)\end{array}$ \\
\hline $2-6 \mathrm{C}$ & 5,5 & 0,055 & 94,5 & 1226,6 & 736,9 & 1227,9 & 490 & 0,26 & 2,498 & 2,616 & 4,5 & 17,7 & 74,6 \\
\hline $3-6 \mathrm{C}$ & 5,5 & 0,055 & 94,5 & 1217,4 & 733,7 & 1218,9 & 484 & 0,31 & 2,509 & 2,616 & 4,1 & 17,4 & 76,4 \\
\hline $4-6 \mathrm{C}$ & 5,5 & 0,055 & 94,5 & 1221,2 & 733,8 & 1222,6 & 487 & 0,29 & 2,498 & 2,616 & 4,5 & 17,7 & 74,6 \\
\hline $6-6 \mathrm{C}$ & 5,5 & 0,055 & 94,5 & 1239,0 & 737,3 & 1225,3 & 502 & $-2,81$ & 2,539 & 2,616 & 2,9 & 16,4 & 82,0 \\
\hline $7-6 \mathrm{C}$ & 5,5 & 0,055 & 94,5 & 1224,4 & 741,6 & 1241,1 & 483 & 3,34 & 2,451 & 2,616 & 6,3 & 19,3 & 67,3 \\
\hline médias & 5,5 & 0,055 & 94,5 & 1226,9 & 737,17 & 1228,1 & 490 & 0,25 & 2,499 & 2,616 & 4,5 & 17,7 & 74,9 \\
\hline $1-6 \mathrm{D}$ & 6,0 & 0,06 & 94 & 1229,2 & 741,5 & 1230,6 & 488 & 0,29 & 2,513 & 2,595 & 3,2 & 17,7 & 82,1 \\
\hline $2-6 \mathrm{D}$ & 6,0 & 0,06 & 94 & 1209,0 & 730,4 & 1209,6 & 479 & 0,13 & 2,523 & 2,595 & 2,8 & 17,3 & 83,9 \\
\hline $3-6 \mathrm{D}$ & 6,0 & 0,06 & 94 & 1221,9 & 740,0 & 1222,6 & 482 & 0,15 & 2,532 & 2,595 & 2,4 & 17,0 & 85,7 \\
\hline $4-6 \mathrm{D}$ & 6,0 & 0,06 & 94 & 1225,4 & 739,8 & 1226,2 & 486 & 0,16 & 2,519 & 2,595 & 2,9 & 17,5 & 83,2 \\
\hline $5-6 \mathrm{D}$ & 6,0 & 0,06 & 94 & 1220,5 & 739,1 & 1221,8 & 481 & 0,27 & 2,528 & 2,595 & 2,6 & 17,2 & 85,0 \\
\hline $6-6 \mathrm{D}$ & 6,0 & 0,06 & 94 & 1228,6 & 739,0 & 1232,0 & 490 & 0,69 & 2,492 & 2,595 & 4,0 & 18,3 & 78,3 \\
\hline $7-6 \mathrm{D}$ & 6,0 & 0,06 & 94 & 1225,7 & 739,2 & 1226,3 & 487 & 0,12 & 2,516 & 2,595 & 3,0 & 17,6 & 82,7 \\
\hline médias & 6,0 & 0,06 & 94 & 1222,9 & 738,43 & 1224,2 & 484 & 0,26 & 2,518 & 2,595 & 3,0 & 17,5 & 83,0 \\
\hline $1-6 \mathrm{E}$ & 6,5 & 0,065 & 93,5 & 1216,7 & 728,6 & 1217,4 & 488 & 0,14 & 2,489 & 2,575 & 3,3 & 18,9 & 82,4 \\
\hline $2-6 \mathrm{E}$ & 6,5 & 0,065 & 93,5 & 1226,0 & 736,6 & 1226,6 & 489 & 0,12 & 2,502 & 2,575 & 2,8 & 18,5 & 84,7 \\
\hline $3-6 \mathrm{E}$ & 6,5 & 0,065 & 93,5 & 1227,6 & 737,2 & 1228,2 & 490 & 0,12 & 2,500 & 2,575 & 2,9 & 18,5 & 84,4 \\
\hline $4-6 \mathrm{E}$ & 6,5 & 0,065 & 93,5 & 1231,9 & 743,4 & 1232,5 & 489 & 0,12 & 2,519 & 2,575 & 2,2 & 17,9 & 87,8 \\
\hline $5-6 \mathrm{E}$ & 6,5 & 0,065 & 93,5 & 1221,5 & 733,8 & 1222,9 & 488 & 0,29 & 2,497 & 2,575 & 3,0 & 18,6 & 83,9 \\
\hline $6-6 \mathrm{E}$ & 6,5 & 0,065 & 93,5 & 1225,8 & 737,2 & 1226,8 & 489 & 0,20 & 2,504 & 2,575 & 2,8 & 18,4 & 85,0 \\
\hline $7-6 \mathrm{E}$ & 6,5 & 0,065 & 93,5 & 1218,3 & 730,4 & 1219,4 & 488 & 0,22 & 2,491 & 2,575 & 3,2 & 18,8 & 82,8 \\
\hline médias & 6,5 & 0,065 & 93,5 & 1224 & 735,31 & 1224,8 & 489 & 0,18 & 2,500 & 2,575 & 2,9 & 18,5 & 84,4 \\
\hline
\end{tabular}




\begin{tabular}{c|c|c|c|c}
\hline $\begin{array}{c}\text { Teor } \\
(\mathbf{\%})\end{array}$ & $\begin{array}{c}\text { Dap } \\
\left(\mathbf{g} / \mathbf{c m}^{3}\right)\end{array}$ & $\begin{array}{c}\text { Vv } \\
(\mathbf{\%})\end{array}$ & $\begin{array}{c}\text { VAM } \\
(\mathbf{\%})\end{array}$ & $\begin{array}{c}\text { RBV } \\
(\mathbf{\%})\end{array}$ \\
\hline 4,5 & 2,423 & 7,9 & 19,3 & 57,3 \\
\hline 5,0 & 2,460 & 6,7 & 18,5 & 63,9 \\
\hline 5,5 & 2,499 & 4,5 & 17,7 & 74,9 \\
\hline 6,0 & 2,518 & 3,0 & 17,5 & 83,0 \\
\hline 6,5 & 2,500 & 2,9 & 18,5 & 84,4 \\
\hline
\end{tabular}

\section{Ensaio Marshall - 82-18-0}

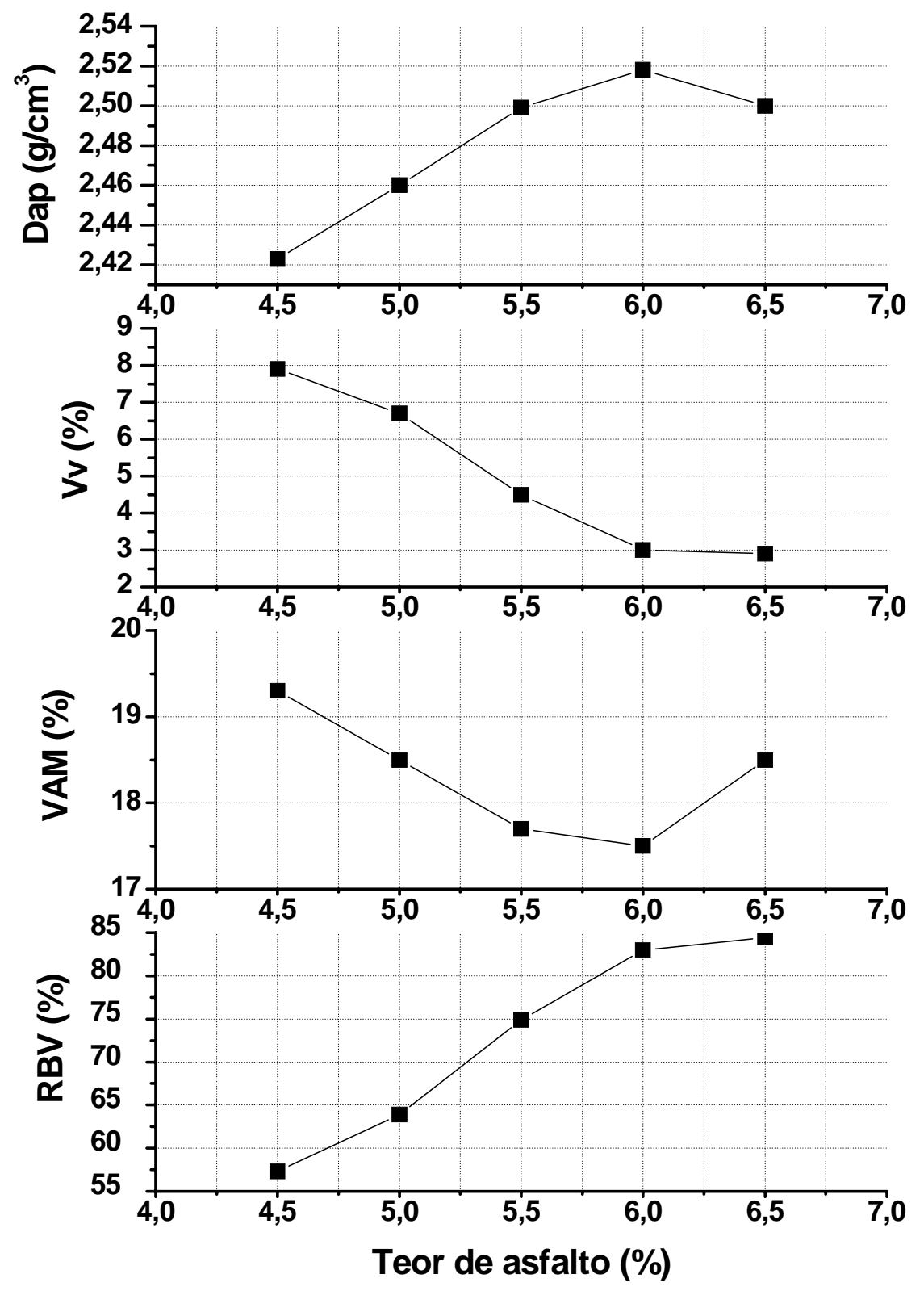

Figura A6: Parâmetros Marshall para mistura 82-18-0 
Planilha de dosagem Marshall - ligante asfáltico 7 (75-18-7)

dens. efetiva do agregado $\quad 2,867$

dens. ponderada dos agregados $\quad 2,869$

dens. do ligante asfáltico $\quad 1,048$

Tabela A7: Parâmetros Marshall para mistura 75-18-7

\begin{tabular}{|c|c|c|c|c|c|c|c|c|c|c|c|c|c|}
\hline $\begin{array}{l}\text { número } \\
\text { do } \mathrm{CP}\end{array}$ & $\begin{array}{c}\% \\
\text { ligante }\end{array}$ & $\begin{array}{c}\% \\
\text { ligante }\end{array}$ & $\begin{array}{c}\% \\
\text { agreg }\end{array}$ & $\begin{array}{c}\text { massa } \\
\text { ao ar }\end{array}$ & $\begin{array}{l}\text { massa } \\
\text { imersa }\end{array}$ & $\begin{array}{c}\text { massa } \\
\text { SSS }\end{array}$ & $\begin{array}{c}\text { volume } \\
\text { CP }\end{array}$ & $\begin{array}{c}\text { absorção } \\
\text { de água }\end{array}$ & $\begin{array}{l}\text { D } \\
\text { ap }\end{array}$ & $\begin{array}{l}\text { DMM } \\
\text { média }\end{array}$ & $\begin{array}{l}\text { Vv } \\
(\%)\end{array}$ & $\begin{array}{l}\text { VAM } \\
(\%)\end{array}$ & $\begin{array}{l}\text { RBV } \\
(\%)\end{array}$ \\
\hline $1-7 \mathrm{~A}$ & 4,5 & 0,045 & 95,5 & 1232,3 & 735,2 & 1233,8 & 497 & 0,30 & 2,472 & 2,659 & 7,1 & 17,7 & 60,2 \\
\hline $2-7 \mathrm{~A}$ & 4,5 & 0,045 & 95,5 & 1228,9 & 733,5 & 1231,7 & 495 & 0,56 & 2,467 & 2,659 & 7,2 & 17,9 & 59,6 \\
\hline $3-7 \mathrm{~A}$ & 4,5 & 0,045 & 95,5 & 1222,4 & 731,3 & 1225,5 & 491 & 0,63 & 2,473 & 2,659 & 7,0 & 17,7 & 60,5 \\
\hline $4-7 \mathrm{~A}$ & 4,5 & 0,045 & 95,5 & 1225,9 & 729,8 & 1228,8 & 496 & 0,58 & 2,457 & 2,659 & 7,6 & 18,2 & 58,2 \\
\hline $5-7 \mathrm{~A}$ & 4,5 & 0,045 & 95,5 & 1232,4 & 736,2 & 1234,8 & 496 & 0,48 & 2,472 & 2,659 & 7,0 & 17,7 & 60,2 \\
\hline $6-7 \mathrm{~A}$ & 4,5 & 0,045 & 95,5 & 1218,3 & 728,1 & 1221,5 & 490 & 0,65 & 2,469 & 2,659 & 7,1 & 17,8 & 59,9 \\
\hline $7-7 \mathrm{~A}$ & 4,5 & 0,045 & 95,5 & 1226,0 & 730,6 & 1229,7 & 495 & 0,74 & 2,456 & 2,659 & 7,6 & 18,2 & 58,2 \\
\hline médias & 4,5 & 0,045 & 95,5 & 1226,6 & 732,1 & 1229,4 & 495 & 0,56 & 2,467 & 2,659 & 7,2 & 17,9 & 59,5 \\
\hline $1-7 \mathrm{~B}$ & 5,0 & 0,050 & 95 & 1221,9 & 735,5 & 1223,0 & 486 & 0,23 & 2,506 & 2,638 & 5,0 & 17,0 & 70,7 \\
\hline $2-7 \mathrm{~B}$ & 5,0 & 0,050 & 95 & 1223,7 & 736,1 & 1224,6 & 488 & 0,18 & 2,505 & 2,638 & 5,0 & 17,1 & 70,5 \\
\hline $3-7 \mathrm{~B}$ & 5,0 & 0,050 & 95 & 1221,2 & 736,4 & 1222,8 & 485 & 0,33 & 2,511 & 2,638 & 4,8 & 16,9 & 71,4 \\
\hline $4-7 \mathrm{~B}$ & 5,0 & 0,050 & 95 & 1222,2 & 735,2 & 1223,6 & 487 & 0,29 & 2,502 & 2,638 & 5,1 & 17,1 & 70,0 \\
\hline $5-7 \mathrm{~B}$ & 5,0 & 0,050 & 95 & 1218,4 & 733,3 & 1220,2 & 485 & 0,37 & 2,502 & 2,638 & 5,1 & 17,1 & 70,0 \\
\hline $6-7 \mathrm{~B}$ & 5,0 & 0,050 & 95 & 1226,8 & 737,5 & 1229,2 & 489 & 0,49 & 2,495 & 2,638 & 5,4 & 17,4 & 68,8 \\
\hline $7-7 \mathrm{~B}$ & 5,0 & 0,050 & 95 & 1229,7 & 738,9 & 1232,0 & 491 & 0,47 & 2,494 & 2,638 & 5,5 & 17,4 & 68,7 \\
\hline médias & 5,0 & 0,050 & 95 & 1223,4 & 736,1 & 1225,1 & 487 & 0,34 & 2,502 & 2,638 & 5,1 & 17,1 & 70,0 \\
\hline $1-7 \mathrm{C}$ & 5,5 & 0,055 & 94,5 & 1225,0 & 734,7 & 1225,9 & 490 & 0,18 & 2,494 & 2,617 & 4,7 & 17,9 & 73,7 \\
\hline $2-7 \mathrm{C}$ & 5,5 & 0,055 & 94,5 & 1234,2 & 741,0 & 1235,4 & 493 & 0,24 & 2,496 & 2,617 & 4,6 & 17,8 & 74,1 \\
\hline $3-7 C$ & 5,5 & 0,055 & 94,5 & 1228,1 & 735,3 & 1229,8 & 493 & 0,34 & 2,484 & 2,617 & 5,1 & 18,2 & 72,0 \\
\hline
\end{tabular}




\begin{tabular}{|c|c|c|c|c|c|c|c|c|c|c|c|c|c|}
\hline $\begin{array}{c}\text { número } \\
\text { do } \mathrm{CP}\end{array}$ & $\begin{array}{c}\% \\
\text { ligante }\end{array}$ & $\begin{array}{c}\% \\
\text { ligante }\end{array}$ & $\begin{array}{c}\% \\
\text { agreg }\end{array}$ & $\begin{array}{c}\text { massa } \\
\text { ao ar }\end{array}$ & $\begin{array}{l}\text { massa } \\
\text { imersa }\end{array}$ & $\begin{array}{c}\text { massa } \\
\text { SSS }\end{array}$ & $\begin{array}{c}\text { volume } \\
\text { CP }\end{array}$ & $\begin{array}{c}\text { absorção } \\
\text { de água }\end{array}$ & $\begin{array}{c}\text { D } \\
\text { ap }\end{array}$ & $\begin{array}{l}\text { DMM } \\
\text { média }\end{array}$ & $\begin{array}{l}\text { Vv } \\
(\%)\end{array}$ & $\begin{array}{c}\text { VAM } \\
(\%)\end{array}$ & $\begin{array}{l}\text { RBV } \\
(\%)\end{array}$ \\
\hline $4-7 \mathrm{C}$ & 5,5 & 0,055 & 94,5 & 1225,0 & 736,9 & 1225,9 & 488 & 0,18 & 2,505 & 2,617 & 4,3 & 17,5 & 75,5 \\
\hline $5-7 \mathrm{C}$ & 5,5 & 0,055 & 94,5 & 1224,5 & 734,5 & 1225,5 & 490 & 0,20 & 2,494 & 2,617 & 4,7 & 17,9 & 73,7 \\
\hline $6-7 \mathrm{C}$ & 5,5 & 0,055 & 94,5 & 1223,8 & 735,3 & 1225,3 & 489 & 0,31 & 2,498 & 2,617 & 4,6 & 17,7 & 74,3 \\
\hline $7-7 \mathrm{C}$ & 5,5 & 0,055 & 94,5 & 1226,6 & 735,8 & 1228,3 & 491 & 0,35 & 2,491 & 2,617 & 4,8 & 18,0 & 73,1 \\
\hline médias & 5,5 & 0,055 & 94,5 & 1226,7 & 736,2 & 1228 & 491 & 0,26 & 2,494 & 2,617 & 4,7 & 17,8 & 73,8 \\
\hline $1-7 \mathrm{D}$ & 6,0 & 0,060 & 94 & 1221,2 & 736,3 & 1222,1 & 485 & 0,19 & 2,514 & 2,596 & 3,2 & 17,6 & 82,0 \\
\hline $2-7 \mathrm{D}$ & 6,0 & 0,060 & 94 & 1229,3 & 745,2 & 1230,3 & 484 & 0,21 & 2,534 & 2,596 & 2,4 & 17,0 & 85,9 \\
\hline $3-7 \mathrm{D}$ & 6,0 & 0,060 & 94 & 1213,0 & 734,6 & 1213,8 & 478 & 0,17 & 2,531 & 2,596 & 2,5 & 17,1 & 85,3 \\
\hline 4-7D & 6,0 & 0,060 & 94 & 1220,1 & 735,0 & 1221,0 & 485 & 0,19 & 2,510 & 2,596 & 3,3 & 17,7 & 81,3 \\
\hline 5-7D & 6,0 & 0,060 & 94 & 1226,1 & 742,7 & 1227,3 & 483 & 0,25 & 2,530 & 2,596 & 2,6 & 17,1 & 85,1 \\
\hline 6-7D & 6,0 & 0,060 & 94 & 1226,1 & 742,2 & 1227,3 & 484 & 0,25 & 2,528 & 2,596 & 2,7 & 17,2 & 84,6 \\
\hline $7-7 \mathrm{D}$ & 6,0 & 0,060 & 94 & 1226,5 & 739,1 & 1228,9 & 487 & 0,49 & 2,504 & 2,596 & 3,6 & 18,0 & 80,2 \\
\hline médias & 6,0 & 0,060 & 94 & 1223,2 & 739,3 & 1224,4 & 484 & 0,25 & 2,522 & 2,596 & 2,9 & 17,4 & 83,5 \\
\hline $1-7 \mathrm{E}$ & 6,5 & 0,065 & 93,5 & 1229,6 & 741,6 & 1229,9 & 488 & 0,06 & 2,518 & 2,576 & 2,3 & 17,9 & 87,4 \\
\hline $2-7 E$ & 6,5 & 0,065 & 93,5 & 1214,2 & 730,6 & 1214,7 & 484 & 0,10 & 2,508 & 2,576 & 2,6 & 18,3 & 85,5 \\
\hline $3-7 E$ & 6,5 & 0,065 & 93,5 & 1218,5 & 733,6 & 1219,2 & 485 & 0,14 & 2,509 & 2,576 & 2,6 & 18,2 & 85,7 \\
\hline $4-7 E$ & 6,5 & 0,065 & 93,5 & 1214,7 & 731,2 & 1215,4 & 484 & 0,14 & 2,509 & 2,576 & 2,6 & 18,2 & 85,6 \\
\hline $5-7 \mathrm{E}$ & 6,5 & 0,065 & 93,5 & 1215,4 & 729,7 & 1216,0 & 486 & 0,12 & 2,499 & 2,576 & 3,0 & 18,5 & 83,9 \\
\hline $6-7 E$ & 6,5 & 0,065 & 93,5 & 1215,9 & 728,6 & 1216,7 & 487 & 0,16 & 2,491 & 2,576 & 3,3 & 18,8 & 82,4 \\
\hline $7-7 \mathrm{E}$ & 6,5 & 0,065 & 93,5 & 1214,4 & 729,7 & 1215,2 & 485 & 0,16 & 2,501 & 2,576 & 2,9 & 18,5 & 84,3 \\
\hline médias & 6,5 & 0,065 & 93,5 & 1217,5 & 732,1 & 1218,2 & 485 & 0,13 & 2,505 & 2,576 & 2,8 & 18,4 & 85,0 \\
\hline
\end{tabular}




\begin{tabular}{c|c|c|c|c}
\hline $\begin{array}{c}\text { Teor } \\
(\mathbf{\%})\end{array}$ & $\begin{array}{c}\text { Dap } \\
\left(\mathbf{g} / \mathbf{c m}^{3}\right)\end{array}$ & $\begin{array}{c}\text { Vv } \\
\mathbf{( \% )}\end{array}$ & $\begin{array}{c}\text { VAM } \\
(\mathbf{\%})\end{array}$ & $\begin{array}{c}\text { RBV } \\
(\mathbf{\%})\end{array}$ \\
\hline 4,5 & 2,467 & 7,2 & 17,9 & 59,5 \\
\hline 5,0 & 2,502 & 5,1 & 17,1 & 70,0 \\
\hline 5,5 & 2,494 & 4,7 & 17,8 & 73,8 \\
\hline 6,0 & 2,522 & 2,9 & 17,4 & 83,5 \\
\hline 6,5 & 2,505 & 2,8 & 18,4 & 85,0 \\
\hline
\end{tabular}

Ensaio Marshall - 75-18-7

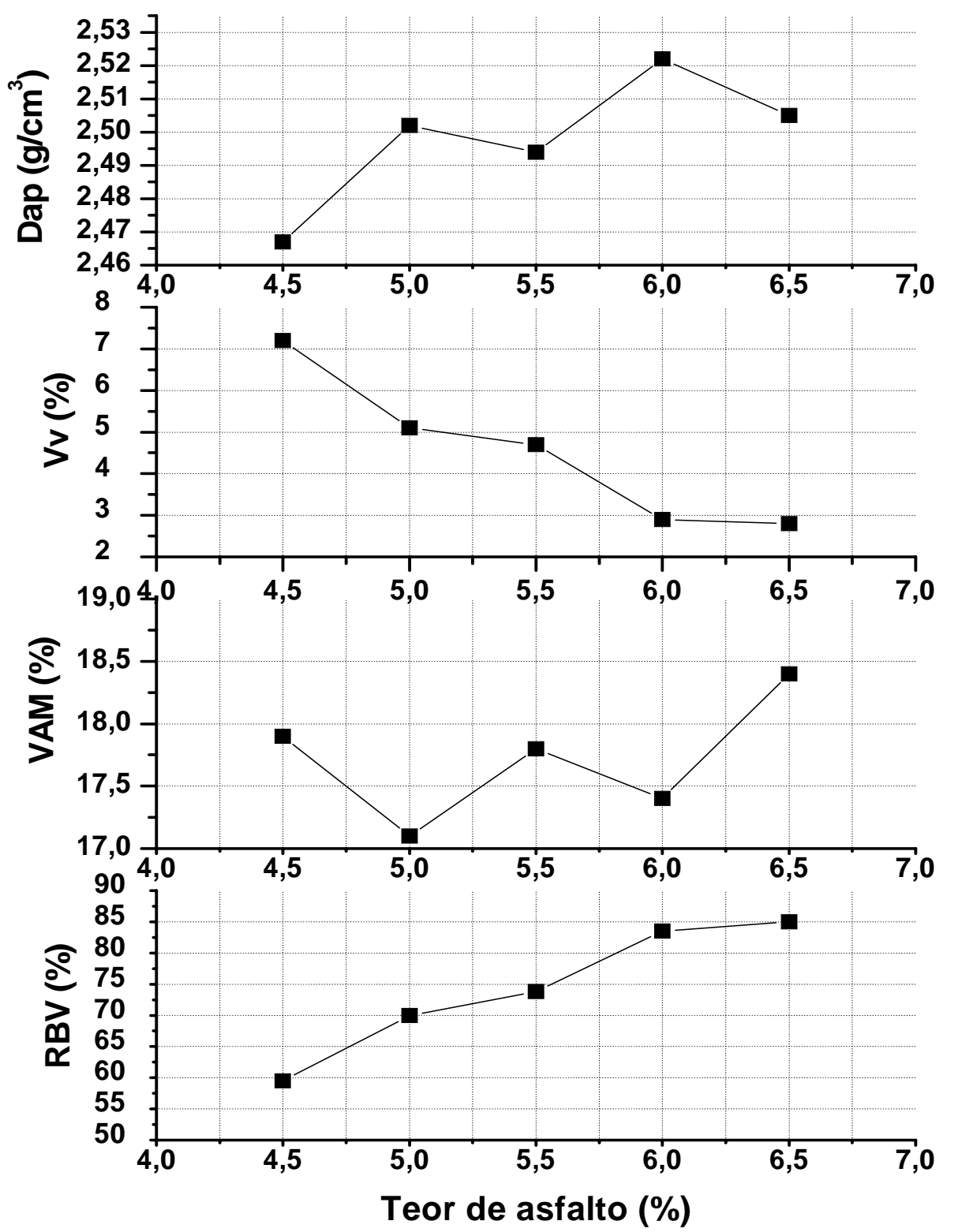

Figura A7: Parâmetros Marshall para mistura 75-18-7 


\section{Planilha de dosagem Marshall - ligante asfáltico 8 (68-18-14)}

dens. efetiva do agregado dens. ponderada dos agregados dens. do ligante asfáltico
2,869

2,869

1,051

Tabela A8: Parâmetros Marshall para mistura 68-18-14

\begin{tabular}{|c|c|c|c|c|c|c|c|c|c|c|c|c|c|}
\hline $\begin{array}{c}\text { número } \\
\text { do CP }\end{array}$ & $\begin{array}{c}\% \\
\text { ligante }\end{array}$ & $\begin{array}{c}\% \\
\text { ligante }\end{array}$ & $\begin{array}{c}\% \\
\text { agreg }\end{array}$ & $\begin{array}{c}\text { massa } \\
\text { ao ar }\end{array}$ & $\begin{array}{l}\text { massa } \\
\text { imersa }\end{array}$ & $\begin{array}{c}\text { massa } \\
\text { SSS }\end{array}$ & $\begin{array}{c}\text { volume } \\
\text { CP }\end{array}$ & $\begin{array}{c}\text { absorção } \\
\text { de água }\end{array}$ & $\begin{array}{c}\text { D } \\
\text { ap }\end{array}$ & $\begin{array}{l}\text { DMM } \\
\text { média }\end{array}$ & $\begin{array}{l}\text { Vv } \\
(\%)\end{array}$ & $\begin{array}{c}\text { VAM } \\
\text { (\%) }\end{array}$ & $\begin{array}{l}\text { RBV } \\
(\%)\end{array}$ \\
\hline $1-8 \mathrm{~A}$ & 4,5 & 0,045 & 95,5 & 1204,3 & 699,4 & 1206,1 & 505 & 0,36 & 2,377 & 2,662 & 10,7 & 20,9 & 48,7 \\
\hline $2-8 \mathrm{~A}$ & 4,5 & 0,045 & 95,5 & 1197,8 & 695,2 & 1199,6 & 503 & 0,36 & 2,375 & 2,662 & 10,8 & 21,0 & 48,5 \\
\hline $3-8 \mathrm{~A}$ & 4,5 & 0,045 & 95,5 & 1202,5 & 701,0 & 1204,4 & 502 & 0,38 & 2,389 & 2,662 & 10,3 & 20,5 & 49,9 \\
\hline $4-8 \mathrm{~A}$ & 4,5 & 0,045 & 95,5 & 1202,4 & 699,5 & 1205,8 & 503 & 0,67 & 2,375 & 2,662 & 10,8 & 20,9 & 48,6 \\
\hline $5-8 \mathrm{~A}$ & 4,5 & 0,045 & 95,5 & 1207,9 & 708,2 & 1210,6 & 500 & 0,54 & 2,404 & 2,662 & 9,7 & 20,0 & 51,6 \\
\hline $6-8 \mathrm{~A}$ & 4,5 & 0,045 & 95,5 & 1202,8 & 702,5 & 1206,2 & 500 & 0,68 & 2,388 & 2,662 & 10,3 & 20,5 & 49,9 \\
\hline $7-8 \mathrm{~A}$ & 4,5 & 0,045 & 95,5 & 1209,2 & 705,2 & 1211,8 & 504 & 0,51 & 2,387 & 2,662 & 10,3 & 20,5 & 49,7 \\
\hline médias & 4,5 & 0,045 & 95,5 & 1204 & 701,6 & 1206 & 502,3 & 0,50 & 2,385 & 2,662 & 10,4 & 20,6 & 49,6 \\
\hline $1-8 \mathrm{~B}$ & 5,0 & 0,050 & 95 & 1204,1 & 703,5 & 1205,5 & 501 & 0,28 & 2,399 & 2,641 & 9,2 & 20,6 & 55,5 \\
\hline $2-8 \mathrm{~B}$ & 5,0 & 0,050 & 95 & 1199,0 & 701,8 & 1200,9 & 497 & 0,38 & 2,402 & 2,641 & 9,0 & 20,5 & 55,9 \\
\hline $3-8 \mathrm{~B}$ & 5,0 & 0,050 & 95 & 1213,3 & 710,8 & 1215,1 & 503 & 0,36 & 2,406 & 2,641 & 8,9 & 20,3 & 56,3 \\
\hline $4-8 \mathrm{~B}$ & 5,0 & 0,050 & 95 & 1204,7 & 702,0 & 1206,5 & 503 & 0,36 & 2,388 & 2,641 & 9,6 & 20,9 & 54,3 \\
\hline $5-8 \mathrm{~B}$ & 5,0 & 0,050 & 95 & 1203,5 & 701,1 & 1205,3 & 502 & 0,36 & 2,387 & 2,641 & 9,6 & 21,0 & 54,2 \\
\hline $6-8 \mathrm{~B}$ & 5,0 & 0,050 & 95 & 1216,4 & 711,6 & 1218,3 & 505 & 0,37 & 2,401 & 2,641 & 9,1 & 20,5 & 55,7 \\
\hline $7-8 \mathrm{~B}$ & 5,0 & 0,050 & 95 & 1209,2 & 707,2 & 1211,8 & 502 & 0,52 & 2,396 & 2,641 & 9,2 & 20,7 & 55,2 \\
\hline médias & 5,0 & 0,050 & 95 & 1207 & 705,4 & 1209 & 501,7 & 0,37 & 2,397 & 2,641 & 9,2 & 20,6 & 55,3 \\
\hline $1-8 \mathrm{C}$ & 5,5 & 0,055 & 94,5 & 1201,8 & 711,0 & 1203,3 & 491 & 0,30 & 2,441 & 2,620 & 6,8 & 19,6 & 65,2 \\
\hline $2-8 \mathrm{C}$ & 5,5 & 0,055 & 94,5 & 1210,4 & 714,8 & 1212,5 & 496 & 0,42 & 2,432 & 2,620 & 7,2 & 19,9 & 64,0 \\
\hline $3-8 \mathrm{C}$ & 5,5 & 0,055 & 94,5 & 1202,0 & 711,2 & 1203,5 & 491 & 0,30 & 2,442 & 2,620 & 6,8 & 19,6 & 65,3 \\
\hline
\end{tabular}




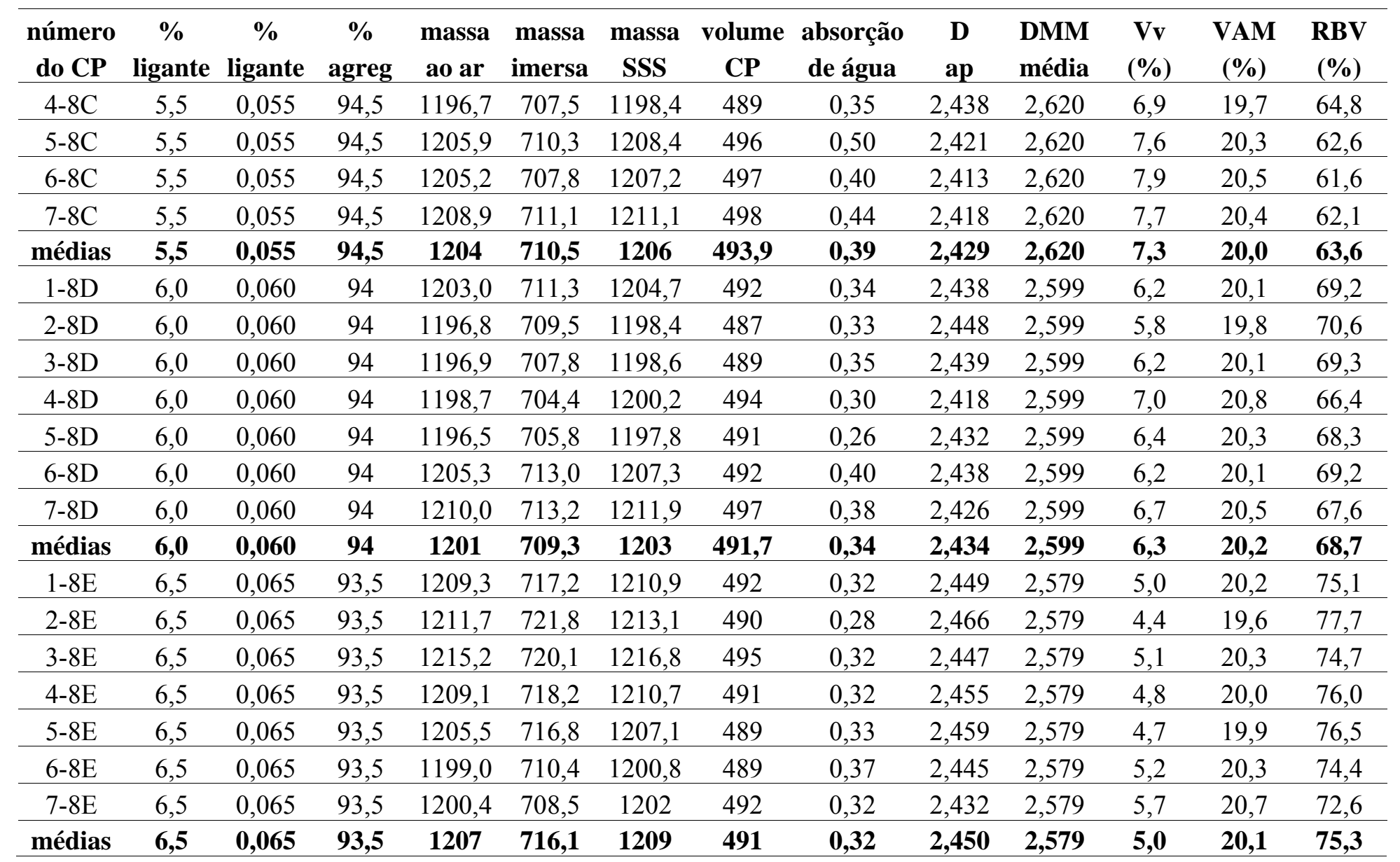




\begin{tabular}{c|c|c|c|c}
\hline $\begin{array}{c}\text { Teor } \\
(\mathbf{\%})\end{array}$ & $\begin{array}{c}\text { Dap } \\
\left(\mathbf{g} / \mathbf{c m}^{3}\right)\end{array}$ & $\begin{array}{c}\text { Vv } \\
\mathbf{( \% )}\end{array}$ & $\begin{array}{c}\text { VAM } \\
\mathbf{( \% )}\end{array}$ & $\begin{array}{c}\text { RBV } \\
(\mathbf{\%})\end{array}$ \\
\hline 4,5 & 2,385 & 10,4 & 20,6 & 49,6 \\
\hline 5,0 & 2,397 & 9,2 & 20,6 & 55,3 \\
\hline 5,5 & 2,429 & 7,3 & 20,0 & 63,6 \\
\hline 6,0 & 2,434 & 6,3 & 20,2 & 68,7 \\
\hline 6,5 & 2,450 & 5,0 & 20,1 & 75,3 \\
\hline
\end{tabular}

Ensaio Marshall - 68-18-14

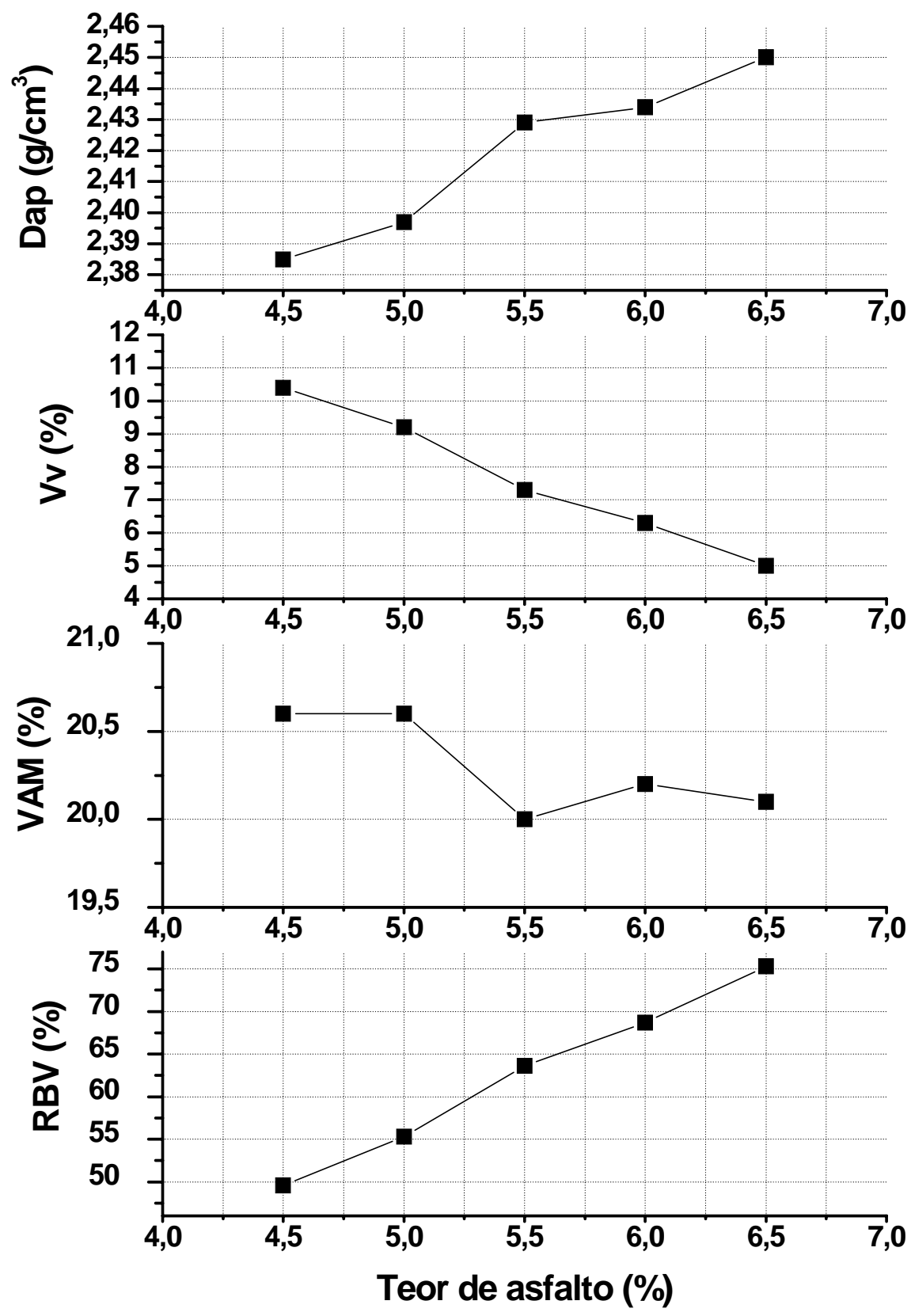

Figura A8: Parâmetros Marshall para mistura 68-18-14 
Tabela B1: Estabilidade e Fluência Marshall para mistura

\begin{tabular}{|c|c|c|c|c|c|}
\hline Corpo-de-prova & E (Kg) & $E(N)$ & $\begin{array}{l}\text { Média } \\
\text { E (N) }\end{array}$ & F (mm) & $\begin{array}{c}\text { Média F } \\
(\mathbf{m m})\end{array}$ \\
\hline $2-1 \mathrm{~A}$ & 1832 & 17972 & \multirow{2}{*}{17741} & 3,59 & \multirow{2}{*}{3,41} \\
\hline $3-1 \mathrm{~A}$ & 1785 & 17511 & & 3,22 & \\
\hline $7-1 \mathrm{~B}$ & 1468 & 14401 & \multirow{2}{*}{14828} & 3,96 & \multirow{2}{*}{3,55} \\
\hline $1-1 \mathrm{~B}$ & 1555 & 15255 & & 3,13 & \\
\hline $3-1 \mathrm{C}$ & 1649 & 16177 & \multirow{2}{*}{15868} & 4,06 & \multirow{2}{*}{3,99} \\
\hline $1-1 \mathrm{C}$ & 1586 & 15559 & & 3,92 & \\
\hline $7-1 \mathrm{D}$ & 1434 & 14068 & \multirow{2}{*}{14166} & 4,16 & \multirow{2}{*}{4,17} \\
\hline $5-1 \mathrm{D}$ & 1454 & 14264 & & 4,17 & \\
\hline $3-1 \mathrm{E}$ & 1328 & 13028 & \multirow{2}{*}{11875} & 5,07 & \multirow{2}{*}{4,86} \\
\hline $7-1 \mathrm{E}$ & 1093 & 10722 & & 4,64 & \\
\hline $2-2 \mathrm{~A}$ & 1499 & 14705 & \multirow{2}{*}{14892} & 2,51 & \multirow{2}{*}{2,73} \\
\hline $5-2 \mathrm{~A}$ & 1537 & 15078 & & 2,95 & \\
\hline $7-2 B$ & 1515 & 14862 & \multirow{2}{*}{13979} & 3,06 & \multirow{2}{*}{2,88} \\
\hline $5-2 \mathrm{~B}$ & 1335 & 13096 & & 2,70 & \\
\hline $5-2 \mathrm{C}$ & 1186 & 11635 & \multirow{2}{*}{13057} & 3,93 & \multirow{2}{*}{4,01} \\
\hline $6-2 \mathrm{C}$ & 1476 & 14480 & & 4,09 & \\
\hline $4-2 \mathrm{D}$ & 1398 & 13714 & \multirow{2}{*}{13450} & 5,17 & \multirow{2}{*}{5,65} \\
\hline $3-2 \mathrm{D}$ & 1344 & 13185 & & 6,12 & \\
\hline $3-2 \mathrm{E}$ & 1008 & 9888 & \multirow{2}{*}{10668} & 4,22 & \multirow{2}{*}{4,53} \\
\hline $1-2 \mathrm{E}$ & 1167 & 11448 & & 4,84 & \\
\hline $6-3 \mathrm{~A}$ & 1234 & 12106 & \multirow{2}{*}{12032} & 2,93 & \multirow{2}{*}{2,94} \\
\hline $2-3 \mathrm{~A}$ & 1219 & 11958 & & 2,94 & \\
\hline $3-3 \mathrm{~B}$ & 1375 & 13489 & \multirow{2}{*}{13592} & 2,74 & \multirow{2}{*}{2,73} \\
\hline $7-3 \mathrm{~B}$ & 1396 & 13695 & & 2,71 & \\
\hline $7-3 \mathrm{C}$ & 1305 & 12802 & \multirow{2}{*}{13018} & 2,98 & \multirow{2}{*}{3,11} \\
\hline $4-3 C$ & 1349 & 13234 & & 3,24 & \\
\hline $1-3 \mathrm{D}$ & 1106 & 10850 & 10094 & 4,21 & 420 \\
\hline $3-3 \mathrm{D}$ & 952 & 9339 & & 4,19 & \\
\hline $3-3 \mathrm{E}$ & 1092 & 10713 & 10570 & 4,18 & 434 \\
\hline $6-3 \mathrm{E}$ & 1063 & 10428 & & 4,49 & \\
\hline $5-4 \mathrm{~A}$ & 1524 & 14950 & 15338 & 3,35 & 3.37 \\
\hline $6-4 \mathrm{~A}$ & 1603 & 15725 & & 3,39 & \\
\hline $6-4 \mathrm{~B}$ & 1811 & 17766 & 15735 & 3,44 & 347 \\
\hline $1-4 \mathrm{~B}$ & 1397 & 13705 & & 3,50 & \\
\hline $4-4 \mathrm{C}$ & 1668 & 16363 & 15710 & 3,45 & 341 \\
\hline $7-4 \mathrm{C}$ & 1541 & 15117 & $15 / 40$ & 3,43 & 5,44 \\
\hline $7-4 \mathrm{D}$ & 1506 & 14774 & 14847 & 3,97 & 4.11 \\
\hline $5-4 \mathrm{D}$ & 1521 & 14921 & & 4,24 & \\
\hline 4-4E & 1503 & 14744 & 14676 & 4,07 & 370 \\
\hline $7-4 \mathrm{E}$ & 1489 & 14607 & & 3,51 & \\
\hline
\end{tabular}




\begin{tabular}{|c|c|c|c|c|c|}
\hline Corpo-de-prova & E (Kg) & $E(N)$ & $\begin{array}{l}\text { Média } \\
\text { E (N) }\end{array}$ & $\begin{array}{c}\mathbf{F} \\
(\mathbf{m m})\end{array}$ & $\begin{array}{c}\text { Média F } \\
\text { (mm) }\end{array}$ \\
\hline $3-5 \mathrm{~A}$ & 2140 & 20993 & \multirow{2}{*}{18575} & 3,35 & \multirow{2}{*}{3,54} \\
\hline $7-5 \mathrm{~A}$ & 1647 & 16157 & & 3,72 & \\
\hline $5-5 \mathrm{~B}$ & 1616 & 15853 & \multirow{2}{*}{15264} & 3,73 & \multirow{2}{*}{3,47} \\
\hline $6-5 B$ & 1496 & 14676 & & 3,21 & \\
\hline $3-5 \mathrm{C}$ & 1437 & 14097 & \multirow{2}{*}{14180} & 3,29 & \multirow{2}{*}{3,40} \\
\hline $1-5 \mathrm{C}$ & 1454 & 14264 & & 3,51 & \\
\hline $7-5 \mathrm{D}$ & 1217 & 11939 & \multirow{2}{*}{12552} & 3,54 & \multirow{2}{*}{3,77} \\
\hline $4-5 \mathrm{D}$ & 1342 & 13165 & & 3,99 & \\
\hline $2-5 \mathrm{E}$ & 1199 & 11762 & \multirow{2}{*}{12675} & 4,24 & \multirow{2}{*}{4,22} \\
\hline $1-5 \mathrm{E}$ & 1385 & 13587 & & 4,20 & \\
\hline $1-6 \mathrm{~A}$ & 1995 & 19571 & \multirow{2}{*}{19321} & 2,74 & \multirow{2}{*}{2,86} \\
\hline $2-6 \mathrm{~A}$ & 1944 & 19071 & & 2,98 & \\
\hline $5-6 \mathrm{~B}$ & 1542 & 15127 & \multirow{2}{*}{18737} & 3,52 & \multirow{2}{*}{3,49} \\
\hline $6-6 \mathrm{~B}$ & 2278 & 22347 & & 3,45 & \\
\hline $6-6 \mathrm{C}$ & 2550 & 25016 & \multirow{2}{*}{23137} & 3,62 & \multirow{2}{*}{3,85} \\
\hline $4-6 \mathrm{C}$ & 2167 & 21258 & & 4,07 & \\
\hline $7-6 \mathrm{D}$ & 1790 & 17560 & \multirow{2}{*}{19630} & 4,17 & \multirow{2}{*}{4,10} \\
\hline $1-6 \mathrm{D}$ & 2212 & 21700 & & 4,02 & \\
\hline $4-6 \mathrm{E}$ & 1825 & 17903 & \multirow{2}{*}{16319} & 4,23 & \multirow{2}{*}{4,21} \\
\hline $2-6 \mathrm{E}$ & 1502 & 14735 & & 4,19 & \\
\hline $4-7 \mathrm{~A}$ & 2157 & 21160 & \multirow{2}{*}{19757} & 3,22 & \multirow{2}{*}{3,02} \\
\hline $7-7 \mathrm{~A}$ & 1871 & 18355 & & 2,82 & \\
\hline $1-7 \mathrm{~B}$ & 2674 & 26232 & \multirow{2}{*}{26693} & 2,95 & \multirow{2}{*}{3,58} \\
\hline $2-7 \mathrm{~B}$ & 2768 & 27154 & & 4,20 & \\
\hline $5-7 \mathrm{C}$ & 2011 & 19728 & \multirow{2}{*}{20312} & 3,67 & \multirow{2}{*}{3,77} \\
\hline $4-7 \mathrm{C}$ & 2130 & 20895 & & 3,87 & \\
\hline $2-7 \mathrm{D}$ & 2442 & 23956 & 21906 & 3,47 & 360 \\
\hline $5-7 \mathrm{D}$ & 2024 & 19855 & & 3,72 & \\
\hline $3-7 \mathrm{E}$ & 1229 & 12056 & 12312 & 5,88 & 615 \\
\hline $1-7 \mathrm{E}$ & 1281 & 12567 & & 6,42 & \\
\hline $3-8 \mathrm{~A}$ & 1238 & 12145 & 11669 & 3,26 & 316 \\
\hline $7-8 \mathrm{~A}$ & 1141 & 11193 & & 3,06 & \\
\hline $2-8 \mathrm{~B}$ & 1256 & 12321 & 11247 & 3,47 & 341 \\
\hline $3-8 \mathrm{~B}$ & 1037 & 10173 & & 3,34 & 5,41 \\
\hline $6-8 \mathrm{C}$ & 1134 & 11125 & 11188 & 3,38 & 333 \\
\hline $7-8 \mathrm{C}$ & 1147 & 11252 & 11100 & 3,27 & נכ,ת \\
\hline $3-8 \mathrm{D}$ & 1446 & 14185 & 13474 & 3,46 & 360 \\
\hline $6-8 \mathrm{D}$ & 1301 & 12763 & & 3,91 & \\
\hline $7-8 \mathrm{E}$ & 1017 & 9977 & 10972 & 4,28 & 403 \\
\hline $1-8 \mathrm{E}$ & 1220 & 11968 & & 3,77 & 4,03 \\
\hline
\end{tabular}


Tabela C1: Módulo de Resiliência das misturas no teor de 4,5\%

* Valores de módulos em MPa.

\begin{tabular}{|c|c|c|c|c|c|}
\hline & \multicolumn{5}{|c|}{ Teor de 4,5\% } \\
\hline Ligante & Ensaio & $\begin{array}{c}\text { Módulo } \\
\text { Total - } \\
\text { DNER* }\end{array}$ & $\begin{array}{c}\text { Módulo } \\
\text { Instantâneo - } \\
\text { DNER* }\end{array}$ & $\begin{array}{c}\text { Módulo } \\
\text { Total - } \\
\text { NCHRP* }\end{array}$ & $\begin{array}{c}\text { Módulo } \\
\text { Instantâneo* } \\
\text { Real - NCHRP }\end{array}$ \\
\hline \multirow{8}{*}{$100-0-0$} & $1-1 \mathrm{~A}$ & 15394 & 23103 & 16506 & 22239 \\
\hline & $2-1 \mathrm{~A}$ & 16111 & 21974 & 15906 & 21667 \\
\hline & $3-1 \mathrm{~A}$ & 18649 & 24019 & 20022 & 24415 \\
\hline & $4-1 \mathrm{~A}$ & 15377 & 21937 & 16198 & 21422 \\
\hline & $5-1 \mathrm{~A}$ & 15292 & 21852 & 16675 & 21907 \\
\hline & $6-1 \mathrm{~A}$ & 16462 & 22356 & 17178 & 22848 \\
\hline & $7-1 \mathrm{~A}$ & 15695 & 24856 & 16806 & 22371 \\
\hline & Média & 16140 & 22871 & 17042 & 22410 \\
\hline \multirow{8}{*}{$93-0-7$} & $1-2 \mathrm{~A}$ & 11549 & 18555 & 12466 & 16934 \\
\hline & $2-2 \mathrm{~A}$ & 12342 & 19810 & 13349 & 17914 \\
\hline & $3-2 \mathrm{~A}$ & 12200 & 19906 & 12015 & 16825 \\
\hline & $4-2 \mathrm{~A}$ & 11947 & 19516 & 13007 & 17371 \\
\hline & $5-2 \mathrm{~A}$ & 14552 & 24816 & 15732 & 21260 \\
\hline & $6-2 \mathrm{~A}$ & 11019 & 18179 & 11826 & 16097 \\
\hline & $7-2 \mathrm{~A}$ & 10813 & 18450 & 11550 & 15703 \\
\hline & Média & 12060 & 19890 & 12849 & 17443 \\
\hline \multirow{8}{*}{$86-0-14$} & $1-3 \mathrm{~A}$ & 7172 & 14057 & 7668 & 10672 \\
\hline & $2-3 \mathrm{~A}$ & 5984 & 11207 & 6053 & 8596 \\
\hline & $3-3 \mathrm{~A}$ & 6661 & 13215 & 6950 & 9708 \\
\hline & $4-3 \mathrm{~A}$ & 6534 & 11748 & 7000 & 9687 \\
\hline & $5-3 A$ & 7150 & 12487 & 7654 & 10477 \\
\hline & $6-3 \mathrm{~A}$ & 7543 & 14123 & 7897 & 11050 \\
\hline & $7-3 \mathrm{~A}$ & 6432 & 11383 & 6664 & 9300 \\
\hline & Média & 6782 & 12603 & 7127 & 9927 \\
\hline \multirow{8}{*}{ 91-9-0 } & $1-4 \mathrm{~A}$ & 11405 & 16498 & 11845 & 15944 \\
\hline & $2-4 \mathrm{~A}$ & 12533 & 18488 & 13238 & 17724 \\
\hline & $3-4 \mathrm{~A}$ & 11277 & 16755 & 11996 & 15967 \\
\hline & $4-4 \mathrm{~A}$ & 10926 & 16500 & 11448 & 15474 \\
\hline & $5-4 A$ & 12942 & 18956 & 13793 & 18265 \\
\hline & $6-4 A$ & 13761 & 20716 & 14808 & 19855 \\
\hline & $7-4 \mathrm{~A}$ & 10899 & 16464 & 11540 & 15545 \\
\hline & Média & 11963 & 17768 & 12667 & 16968 \\
\hline
\end{tabular}




\begin{tabular}{|c|c|c|c|c|c|}
\hline & \multicolumn{5}{|c|}{ Teor de $4,5 \%$} \\
\hline Ligante & Ensaio & $\begin{array}{c}\text { Módulo } \\
\text { Total - } \\
\text { DNER* }\end{array}$ & $\begin{array}{c}\text { Módulo } \\
\text { Instantâneo - } \\
\text { DNER* }\end{array}$ & $\begin{array}{c}\text { Módulo } \\
\text { Total - } \\
\text { NCHRP* }\end{array}$ & $\begin{array}{c}\text { Módulo } \\
\text { Instantâneo } \\
\text { Real - } \\
\text { NCHRP* }\end{array}$ \\
\hline \multirow{8}{*}{ 82-18-0 } & $1-6 \mathrm{~A}$ & 10997 & 16431 & 11738 & 15644 \\
\hline & $2-6 \mathrm{~A}$ & 10281 & 15067 & 10871 & 14565 \\
\hline & 3-6A1 & 12469 & 17275 & 13342 & 17432 \\
\hline & $4-6 \mathrm{~A} 1$ & 16482 & 21581 & 17156 & 21750 \\
\hline & $5-6 \mathrm{~A} 1$ & 18382 & 23511 & 19156 & 23973 \\
\hline & $6-6 \mathrm{~A} 1$ & 18001 & 22595 & 19046 & 23011 \\
\hline & $7-6 \mathrm{~A} 1$ & 17586 & 22995 & 18585 & 22799 \\
\hline & Média & 14885 & 19922 & 15699 & 19882 \\
\hline \multirow{8}{*}{$77-9-14$} & $1-5 \mathrm{~A} 1$ & 11774 & 16617 & 12229 & 16161 \\
\hline & $2-5 \mathrm{~A} 1$ & 10025 & 15297 & 10836 & 14328 \\
\hline & $3-5 \mathrm{~A}$ & 12537 & 17909 & 13257 & 17328 \\
\hline & $4-5 \mathrm{~A} 1$ & 11469 & 16775 & 12275 & 16210 \\
\hline & $5-5 \mathrm{~A} 1$ & 11210 & 16601 & 12134 & 15918 \\
\hline & $6-5 \mathrm{~A} 1$ & 11342 & 16017 & 11707 & 15316 \\
\hline & $7-5 \mathrm{~A} 1$ & 8909 & 13569 & 9469 & 12698 \\
\hline & Média & 11038 & 16112 & 11701 & 15423 \\
\hline \multirow{8}{*}{$75-18-7$} & $1-7 \mathrm{~A}$ & 10741 & 15465 & 11424 & 15056 \\
\hline & $2-7 \mathrm{~A} 1$ & 11516 & 16459 & 12172 & 15920 \\
\hline & $3-7 \mathrm{~A} 1$ & 12486 & 17394 & 13199 & 17277 \\
\hline & 4-7A & 9313 & 13958 & 9846 & 13134 \\
\hline & $5-7 \mathrm{~A}$ & 11380 & 16177 & 12145 & 15894 \\
\hline & 6-7A1 & 11874 & 16778 & 12538 & 16549 \\
\hline & $7-7 \mathrm{~A}$ & 8916 & 13608 & 9371 & 12538 \\
\hline & Média & 10889 & 15691 & 11528 & 15195 \\
\hline \multirow{8}{*}{$\begin{array}{c}\text { 68-18- } \\
14\end{array}$} & $1-8 \mathrm{~A} 1$ & 4955 & 7631 & 5079 & 6990 \\
\hline & $2-8 \mathrm{~A}$ & 5029 & 7676 & 5150 & 7007 \\
\hline & $3-8 \mathrm{~A}$ & 6128 & 9667 & 6275 & 8549 \\
\hline & $4-8 \mathrm{~A}$ & 4924 & 7520 & 4975 & 6907 \\
\hline & 5-8A1 & 5720 & 8914 & 6112 & 8187 \\
\hline & $6-8 \mathrm{~A}$ & 5804 & 8906 & 6052 & 8133 \\
\hline & $7-8 \mathrm{~A} 1$ & 4810 & 7506 & 4887 & 6772 \\
\hline & Média & 5339 & 8260 & 5504 & 7506 \\
\hline
\end{tabular}


Tabela C2: Módulo de Resiliência das misturas no teor de 5,0\%

\begin{tabular}{|c|c|c|c|c|c|}
\hline & \multicolumn{5}{|c|}{ Teor de 5,0\% } \\
\hline Ligante & Ensaio & $\begin{array}{c}\text { Módulo } \\
\text { Total - } \\
\text { DNER* }\end{array}$ & $\begin{array}{c}\text { Módulo } \\
\text { Instantâneo - } \\
\text { DNER* }\end{array}$ & $\begin{array}{c}\text { Módulo } \\
\text { Total - } \\
\text { NCHRP* }\end{array}$ & $\begin{array}{c}\text { Módulo } \\
\text { Instantâneo } \\
\text { Real - } \\
\text { NCHRP* }\end{array}$ \\
\hline \multirow{8}{*}{$100-0-0$} & $1-1 \mathrm{~B}$ & 17266 & 24335 & 18096 & 23840 \\
\hline & $2-1 B$ & 19431 & 24904 & 20471 & 26777 \\
\hline & $3-1 B$ & 19022 & 26342 & 20191 & 26908 \\
\hline & $4-1 \mathrm{~B}$ & 15881 & 24250 & 17570 & 23315 \\
\hline & $5-1 \mathrm{~B}$ & 17515 & 24971 & 18758 & 24513 \\
\hline & $6-1 \mathrm{~B}$ & 17360 & 25295 & 18357 & 24380 \\
\hline & $7-1 B$ & 15596 & 22401 & 16293 & 21907 \\
\hline & Média & 17439 & 24642 & 18534 & 24520 \\
\hline \multirow{8}{*}{ 93-0-7 } & $1-2 \mathrm{~B} 1$ & 11796 & 18338 & 12723 & 17285 \\
\hline & $2-2 B$ & 12308 & 20294 & 13232 & 18014 \\
\hline & $3-2 \mathrm{~B}$ & 12099 & 19456 & 13092 & 17558 \\
\hline & $4-2 B$ & 11959 & 19368 & 13014 & 17815 \\
\hline & $5-2 B$ & 11066 & 17952 & 11637 & 15959 \\
\hline & $6-2 \mathrm{~B} 1$ & 11095 & 18749 & 11687 & 16118 \\
\hline & $7-2 B$ & 10397 & 17428 & 11043 & 15078 \\
\hline & Média & 11531 & 18798 & 12347 & 16832 \\
\hline \multirow{8}{*}{$86-0-14$} & $1-3 \mathrm{~B}$ & 6940 & 13372 & 7115 & 10056 \\
\hline & $2-3 B$ & 7205 & 14254 & 7519 & 10644 \\
\hline & $3-3 B$ & 7711 & 13369 & 8089 & 11087 \\
\hline & $4-3 \mathrm{~B}$ & 6651 & 13330 & 6886 & 9709 \\
\hline & $5-3 \mathrm{~B}$ & 7135 & 14056 & 7388 & 10446 \\
\hline & $6-3 \mathrm{~B}$ & 6785 & 12983 & 6978 & 9960 \\
\hline & $7-3 B$ & 6246 & 10972 & 6537 & 9098 \\
\hline & Média & 6953 & 13191 & 7216 & 10143 \\
\hline \multirow{8}{*}{ 91-9-0 } & $1-4 \mathrm{~B}$ & 16614 & 23625 & 17635 & 23548 \\
\hline & $2-4 B$ & 15758 & 22544 & 16538 & 22331 \\
\hline & $3-4 \mathrm{~B} 1$ & 15577 & 23065 & 16484 & 22050 \\
\hline & 4-4B1 & 14256 & 21355 & 15052 & 20356 \\
\hline & $5-4 \mathrm{~B}$ & 15591 & 22715 & 16650 & 22339 \\
\hline & 6-4B & 16904 & 24296 & 17715 & 23246 \\
\hline & $7-4 \mathrm{~B}$ & 15923 & 22371 & 16265 & 21937 \\
\hline & Média & 15803 & 22853 & 16620 & 22258 \\
\hline
\end{tabular}




\begin{tabular}{|c|c|c|c|c|c|}
\hline & \multicolumn{5}{|c|}{ Teor de 5,0\% } \\
\hline Ligante & Ensaio & $\begin{array}{c}\text { Módulo } \\
\text { Total - } \\
\text { DNER* }\end{array}$ & $\begin{array}{c}\text { Módulo } \\
\text { Instantâneo - } \\
\text { DNER* }\end{array}$ & $\begin{array}{c}\text { Módulo } \\
\text { Total - } \\
\text { NCHRP* }\end{array}$ & $\begin{array}{c}\text { Módulo } \\
\text { Instantâneo } \\
\text { Real - } \\
\text { NCHRP* }\end{array}$ \\
\hline \multirow{8}{*}{ 82-18-0 } & $1-6 \mathrm{~B} 1$ & 10834 & 15965 & 11600 & 15197 \\
\hline & $2-6 \mathrm{~B}$ & 9872 & 15091 & 10517 & 13865 \\
\hline & $3-6 \mathrm{~B}$ & 9400 & 14379 & 9960 & 13154 \\
\hline & $4-6 \mathrm{~B} 1$ & 10421 & 15597 & 11221 & 14836 \\
\hline & $5-6 \mathrm{~B}$ & 8986 & 13263 & 9514 & 12676 \\
\hline & $6-6 \mathrm{~B}$ & 11746 & 16938 & 12406 & 16503 \\
\hline & $7-6 \mathrm{~B} 1$ & 10481 & 14797 & 10990 & 14477 \\
\hline & Média & 10248 & 15147 & 10887 & 14387 \\
\hline \multirow{8}{*}{$77-9-14$} & $1-5 B$ & 9881 & 15236 & 10433 & 14083 \\
\hline & $2-5 B 1$ & 8796 & 13557 & 9232 & 12507 \\
\hline & $3-5 B$ & 9826 & 15239 & 10435 & 14012 \\
\hline & $4-5 \mathrm{~B} 1$ & 10004 & 15633 & 10706 & 14419 \\
\hline & $5-5 \mathrm{~B} 1$ & 11150 & 17380 & 11784 & 15965 \\
\hline & $6-5 B$ & 8827 & 13999 & 9309 & 12537 \\
\hline & $7-5 B$ & 9293 & 14859 & 10275 & 13838 \\
\hline & Média & 9682 & 15129 & 10311 & 13909 \\
\hline \multirow{8}{*}{$75-18-7$} & $1-7 \mathrm{~B}$ & 10217 & 14047 & 10810 & 13728 \\
\hline & $2-7 \mathrm{~B}$ & 10103 & 13928 & 10622 & 13947 \\
\hline & $3-7 \mathrm{~B}$ & 9021 & 12524 & 8882 & 12191 \\
\hline & 4-7B & 10071 & 14298 & 10429 & 13909 \\
\hline & $5-7 \mathrm{~B} 1$ & 9179 & 12963 & 9700 & 12831 \\
\hline & $6-7 \mathrm{~B}$ & 8292 & 12294 & 8812 & 11683 \\
\hline & $7-7 \mathrm{~B} 1$ & 8735 & 12795 & 9433 & 12462 \\
\hline & Média & 9374 & 13264 & 9813 & 12965 \\
\hline \multirow{8}{*}{$\begin{array}{c}\text { 68-18- } \\
14\end{array}$} & $1-8 \mathrm{~B} 1$ & 4603 & 6630 & 4613 & 6298 \\
\hline & $2-8 \mathrm{~B}$ & 4849 & 7318 & 4873 & 6787 \\
\hline & 3-8B1 & 4376 & 6814 & 4510 & 6132 \\
\hline & $4-8 \mathrm{~B}$ & 4623 & 6899 & 4630 & 6473 \\
\hline & $5-8 \mathrm{~B} 1$ & 4667 & 6936 & 4637 & 6495 \\
\hline & $6-8 \mathrm{~B} 1$ & 4612 & 7185 & 4613 & 6400 \\
\hline & $7-8 \mathrm{~B} 1$ & 4624 & 7235 & 4770 & 6549 \\
\hline & Média & 4622 & 7002 & 4664 & 6448 \\
\hline
\end{tabular}


Tabela C3: Módulo de Resiliência das misturas no teor de 5,5\%

\begin{tabular}{|c|c|c|c|c|c|}
\hline & \multicolumn{5}{|c|}{ Teor de 5,5\% } \\
\hline Ligante & Ensaio & $\begin{array}{c}\text { Módulo } \\
\text { Total - } \\
\text { DNER* }\end{array}$ & $\begin{array}{c}\text { Módulo } \\
\text { Instantâneo - } \\
\text { DNER* }\end{array}$ & $\begin{array}{c}\text { Módulo } \\
\text { Total - } \\
\text { NCHRP* }\end{array}$ & $\begin{array}{c}\text { Módulo } \\
\text { Instantâneo } \\
\text { Real - } \\
\text { NCHRP* } \\
\end{array}$ \\
\hline \multirow{8}{*}{$100-0-0$} & $1-1 \mathrm{C}$ & 17222 & 24168 & 18305 & 23990 \\
\hline & $2-1 \mathrm{C}$ & 16126 & 23051 & 17226 & 22521 \\
\hline & $3-1 \mathrm{C}$ & 13551 & 21132 & 14406 & 19506 \\
\hline & $4-1 \mathrm{C}$ & 15140 & 23322 & 17076 & 22645 \\
\hline & $5-1 \mathrm{C}$ & 14801 & 23185 & 15778 & 21369 \\
\hline & $6-1 \mathrm{C}$ & 15071 & 23770 & 16384 & 22091 \\
\hline & $7-1 \mathrm{C}$ & 16716 & 24292 & 17549 & 23483 \\
\hline & Média & 15518 & 23274 & 16675 & 22229 \\
\hline \multirow{8}{*}{ 93-0-7 } & $1-2 \mathrm{C} 1$ & 9736 & 17399 & 10497 & 14278 \\
\hline & $2-2 \mathrm{C}$ & 10697 & 18241 & 11555 & 15571 \\
\hline & $3-2 \mathrm{C}$ & 9344 & 15359 & 9908 & 13644 \\
\hline & $4-2 \mathrm{C}$ & 9695 & 15944 & 10391 & 14163 \\
\hline & $5-2 \mathrm{C}$ & 8038 & 15286 & 8628 & 12011 \\
\hline & $6-2 \mathrm{C}$ & 11452 & 22554 & 12103 & 17176 \\
\hline & $7-2 \mathrm{C}$ & 8800 & 15043 & 9420 & 12957 \\
\hline & Média & 9680 & 17118 & 10357 & 14257 \\
\hline \multirow{8}{*}{$86-0-14$} & $1-3 \mathrm{C}$ & 6900 & 12755 & 7352 & 10234 \\
\hline & $2-3 C$ & 6698 & 14673 & 6988 & 9936 \\
\hline & $3-3 C$ & 6784 & 13802 & 7112 & 9957 \\
\hline & $4-3 C$ & 6906 & 12950 & 7632 & 10326 \\
\hline & $5-3 \mathrm{C}$ & 6247 & 11279 & 6622 & 9099 \\
\hline & $6-3 \mathrm{C}$ & 6629 & 12653 & 6909 & 9844.8 \\
\hline & $7-3 C$ & 6194 & 12179 & 6567 & 9156 \\
\hline & Média & 6623 & 12899 & 7026 & 9785 \\
\hline \multirow{8}{*}{ 91-9-0 } & $1-4 \mathrm{C}$ & 14010 & 19737 & 14770 & 19817 \\
\hline & $2-4 \mathrm{C} 1$ & 14257 & 19716 & 14945 & 19998 \\
\hline & $3-4 \mathrm{C}$ & 13232 & 19337 & 14131 & 18933 \\
\hline & $4-4 \mathrm{C} 1$ & 15720 & 21605 & 16645 & 21153 \\
\hline & $5-4 C 1$ & 14028 & 20177 & 14783 & 19777 \\
\hline & $6-4 \mathrm{C} 1$ & 14263 & 20844 & 15046 & 20296 \\
\hline & $7-4 \mathrm{C} 1$ & 13358 & 19578 & 14184 & 18804 \\
\hline & Média & 14124 & 20142 & 14929 & 19825 \\
\hline
\end{tabular}




\begin{tabular}{|c|c|c|c|c|c|}
\hline & \multicolumn{5}{|c|}{ Teor de 5,5\% } \\
\hline Ligante & Ensaio & $\begin{array}{c}\text { Módulo } \\
\text { Total - } \\
\text { DNER* }\end{array}$ & $\begin{array}{c}\text { Módulo } \\
\text { Instantâneo - } \\
\text { DNER* }\end{array}$ & $\begin{array}{c}\text { Módulo } \\
\text { Total - } \\
\text { NCHRP* }\end{array}$ & $\begin{array}{c}\text { Módulo } \\
\text { Instantâneo } \\
\text { Real - } \\
\text { NCHRP* }\end{array}$ \\
\hline \multirow{8}{*}{ 82-18-0 } & $1-6 \mathrm{C} 1$ & 14349 & 18097 & 14669 & 18352 \\
\hline & $2-6 \mathrm{C}$ & 14450 & 18358 & 15225 & 19097 \\
\hline & $3-6 \mathrm{C}$ & 14075 & 18272 & 14656 & 18512 \\
\hline & $4-6 \mathrm{C} 1$ & 11786 & 16297 & 12984 & 16588 \\
\hline & $5-6 \mathrm{C} 1$ & 13505 & 18019 & 15335 & 18700 \\
\hline & $6-6 \mathrm{C} 1$ & 16009 & 20291 & 16915 & 21015 \\
\hline & $7-6 \mathrm{C}$ & 11501 & 16855 & 12585 & 16339 \\
\hline & Média & 13668 & 18027 & 14624 & 18372 \\
\hline \multirow{8}{*}{ 77-9-14 } & $1-5 \mathrm{C}$ & 7541 & 12484 & 7992 & 10875 \\
\hline & $2-5 \mathrm{C} 1$ & 9887 & 15665 & 10314 & 14111 \\
\hline & $3-5 \mathrm{C}$ & 7989 & 13040 & 8387 & 11537 \\
\hline & $4-5 \mathrm{C} 1$ & 9387 & 14790 & 9764 & 13447 \\
\hline & $5-5 \mathrm{C} 1$ & 8915 & 14079 & 9194 & 12749 \\
\hline & $6-5 \mathrm{C} 1$ & 9409 & 14938 & 9880 & 13544 \\
\hline & $7-5 \mathrm{C}$ & 9191 & 15062 & 9679 & 13190 \\
\hline & Média & 8903 & 14294 & 9316 & 12779 \\
\hline \multirow{8}{*}{$75-18-7$} & $1-7 \mathrm{C} 1$ & 8202 & 11848 & 8570 & 11609 \\
\hline & $2-7 \mathrm{C} 1$ & 7597 & 11511 & 8016 & 10928 \\
\hline & $3-7 \mathrm{C}$ & 8013 & 11712 & 8309 & 11307 \\
\hline & $4-7 \mathrm{C} 1$ & 8898 & 12777 & 9265 & 12487 \\
\hline & $5-7 \mathrm{C}$ & 10024 & 15268 & 10449 & 14356 \\
\hline & $6-7 \mathrm{C}$ & 7758 & 11340 & 8131 & 10944 \\
\hline & $7-7 \mathrm{C} 1$ & 8721 & 13230 & 9125 & 12352 \\
\hline & Média & 8459 & 12526 & 8838 & 11997 \\
\hline \multirow{8}{*}{$\begin{array}{c}\text { 68-18- } \\
14\end{array}$} & $1-8 \mathrm{C} 1$ & 6080 & 9326 & 6368 & 8585 \\
\hline & $2-8 \mathrm{C} 1$ & 5943 & 9137 & 6005 & 8402 \\
\hline & $3-8 \mathrm{C}$ & 6069 & 9191 & 6163 & 8590 \\
\hline & $4-8 \mathrm{C} 1$ & 6281 & 9610 & 6460 & 8840 \\
\hline & $5-8 \mathrm{C}$ & 5402 & 8664 & 5518 & 7593 \\
\hline & $6-8 \mathrm{C} 1$ & 4710 & 7383 & 4838 & 6622 \\
\hline & $7-8 \mathrm{C}$ & 4630 & 7633 & 4777 & 6545 \\
\hline & Média & 5588 & 8706 & 5733 & 7882 \\
\hline
\end{tabular}


Tabela C4: Módulo de Resiliência das misturas no teor de 6,0\%

\begin{tabular}{|c|c|c|c|c|c|}
\hline & \multicolumn{5}{|c|}{ Teor de $6,0 \%$} \\
\hline Ligante & Ensaio & $\begin{array}{c}\text { Módulo } \\
\text { Total - } \\
\text { DNER* }\end{array}$ & $\begin{array}{c}\text { Módulo } \\
\text { Instantâneo - } \\
\text { DNER* }\end{array}$ & $\begin{array}{c}\text { Módulo } \\
\text { Total - } \\
\text { NCHRP* }\end{array}$ & $\begin{array}{c}\text { Módulo } \\
\text { Instantâneo } \\
\text { Real - } \\
\text { NCHRP* }\end{array}$ \\
\hline \multirow{8}{*}{$100-0-0$} & $1-1 D$ & 15390 & 23022 & 16746 & 22239 \\
\hline & $2-1 \mathrm{D}$ & 15230 & 22608 & 16320 & 21728 \\
\hline & 3-1D1 & 15930 & 23724 & 17287 & 23056 \\
\hline & 4-1D & 14761 & 22765 & 15931 & 21692 \\
\hline & 5-1D1 & 13512 & 20346 & 14729 & 19513 \\
\hline & 6-1D & 14763 & 22130 & 16412 & 21711 \\
\hline & $7-1 \mathrm{D} 1$ & 16244 & 24787 & 17879 & 23876 \\
\hline & Média & 15119 & 22769 & 16472 & 21973 \\
\hline \multirow{8}{*}{ 93-0-7 } & $1-2 \mathrm{D}$ & 8255 & 17760 & 8723 & 12340 \\
\hline & $2-2 \mathrm{D}$ & 7908 & 13738 & 8784 & 11802 \\
\hline & $3-2 D$ & 10004 & 17639 & 11088 & 14864 \\
\hline & $4-2 \mathrm{D}$ & 5934 & 12128 & 6289 & 8770 \\
\hline & $5-2 \mathrm{D}$ & 7100 & 13849 & 7503 & 10537 \\
\hline & $6-2 \mathrm{D}$ & 8432 & 14775 & 8811 & 12245 \\
\hline & $7-2 \mathrm{D}$ & 7536 & 15253 & 7676 & 10927 \\
\hline & Média & 7881 & 15020 & 8411 & 11641 \\
\hline \multirow{8}{*}{$86-0-14$} & $1-3 D$ & 3557 & 6887 & 3634 & 5157 \\
\hline & $2-3 D$ & 4376 & 8388 & 4466 & 6334 \\
\hline & $3-3 D$ & 3651 & 7408 & 3734 & 5348 \\
\hline & 4-3D & 4000 & 7878 & 4165 & 5834 \\
\hline & $5-3 D$ & 4302 & 8321 & 4453 & 6206 \\
\hline & $6-3 \mathrm{D}$ & 4187 & 7962 & 4309 & 6021 \\
\hline & $7-3 D$ & 4321 & 8409 & 4422 & 6269 \\
\hline & Média & 4056 & 7893 & 4169 & 5881 \\
\hline \multirow{8}{*}{ 91-9-0 } & $1-4 D$ & 14437 & 21111 & 15308 & 20593 \\
\hline & $2-4 D$ & 12960 & 19065 & 13839 & 18378 \\
\hline & 3-4D1 & 12877 & 18678 & 13553 & 18040 \\
\hline & 4-4D & 13023 & 19224 & 14010 & 18501 \\
\hline & $5-4 D$ & 14481 & 21165 & 15378 & 20729 \\
\hline & $6-4 \mathrm{D}$ & 14023 & 20341 & 14885 & 19836 \\
\hline & $7-4 \mathrm{D}$ & 15263 & 23316 & 16032 & 21663 \\
\hline & Média & 13866 & 20414 & 14715 & 19677 \\
\hline
\end{tabular}




\begin{tabular}{|c|c|c|c|c|c|}
\hline & \multicolumn{5}{|c|}{ Teor de $6,0 \%$} \\
\hline Ligante & Ensaio & $\begin{array}{c}\text { Módulo } \\
\text { Total - } \\
\text { DNER* }\end{array}$ & $\begin{array}{c}\text { Módulo } \\
\text { Instantâneo - } \\
\text { DNER* }\end{array}$ & $\begin{array}{c}\text { Módulo } \\
\text { Total - } \\
\text { NCHRP* }\end{array}$ & $\begin{array}{c}\text { Módulo } \\
\text { Instantâneo } \\
\text { Real - } \\
\text { NCHRP* }\end{array}$ \\
\hline \multirow{8}{*}{ 82-18-0 } & $1-6 \mathrm{D} 1$ & 14941 & 19446 & 16367 & 19713 \\
\hline & $2-6 \mathrm{D}$ & 12071 & 16349 & 12829 & 16501 \\
\hline & $3-6 \mathrm{D} 1$ & 12268 & 16463 & 12818 & 16482 \\
\hline & $4-6 \mathrm{D} 1$ & 11155 & 15751 & 11984 & 15449 \\
\hline & $5-6 \mathrm{D}$ & 11628 & 16224 & 12342 & 16219 \\
\hline & $6-6 \mathrm{D}$ & 11391 & 16321 & 12083 & 15751 \\
\hline & $7-6 \mathrm{D}$ & 10512 & 15273 & 11004 & 14643 \\
\hline & Média & 11995 & 16547 & 12775 & 16394 \\
\hline \multirow{8}{*}{$77-9-14$} & $1-5 \mathrm{D} 1$ & 7350 & 12036 & 7867 & 10609 \\
\hline & $2-5 \mathrm{D} 1$ & 7308 & 12033 & 7783 & 10528 \\
\hline & $3-5 \mathrm{D} 1$ & 7116 & 11375 & 7492 & 10114 \\
\hline & $4-5 \mathrm{D}$ & 6522 & 11116 & 6871 & 9461 \\
\hline & $5-5 \mathrm{D} 1$ & 6771 & 11302 & 7164 & 9722 \\
\hline & $6-5 \mathrm{D} 1$ & 7076 & 11773 & 7446 & 10138 \\
\hline & $7-5 \mathrm{D} 1$ & 6651 & 11248 & 6931 & 9586 \\
\hline & Média & 6970 & 11555 & 7365 & 10023 \\
\hline \multirow{8}{*}{$75-18-7$} & $1-7 \mathrm{D}$ & 9626 & 13271 & 10188 & 13326 \\
\hline & $2-7 \mathrm{D}$ & 11463 & 16000 & 12088 & 15820 \\
\hline & $3-7 \mathrm{D}$ & 9017 & 12485 & 9461 & 12461 \\
\hline & 4-7D & 8788 & 12489 & 9305 & 12307 \\
\hline & 5-7D & 11054 & 16162 & 11692 & 15759 \\
\hline & 6-7D1 & 9647 & 13969 & 10171 & 13649 \\
\hline & $7-7 \mathrm{D}$ & 8478 & 12932 & 8991 & 12011 \\
\hline & Média & 9725 & 13901 & 10271 & 13619 \\
\hline \multirow{8}{*}{$\begin{array}{c}\text { 68-18- } \\
14\end{array}$} & $1-8 \mathrm{D}$ & 7614 & 11660 & 7867 & 10816 \\
\hline & $2-8 D$ & 6718 & 9893 & 6881 & 9343 \\
\hline & 3-8D & 7678 & 11602 & 7967 & 10712 \\
\hline & 4-8D1 & 5345 & 8015 & 5491 & 7450 \\
\hline & 5-8D & 6603 & 9873 & 6753 & 9236 \\
\hline & 6-8D1 & 7539 & 11319 & 7570 & 10450 \\
\hline & $7-8 \mathrm{D} 1$ & 6076 & 9307 & 6239 & 8535 \\
\hline & Média & 6796 & 10239 & 6967 & 9506 \\
\hline
\end{tabular}


Tabela C5: Módulo de Resiliência das misturas no teor de 6,5\%

\begin{tabular}{|c|c|c|c|c|c|}
\hline & \multicolumn{5}{|c|}{ Teor de 6,5\% } \\
\hline Ligante & Ensaio & $\begin{array}{c}\text { Módulo } \\
\text { Total - } \\
\text { DNER* }\end{array}$ & $\begin{array}{c}\text { Módulo } \\
\text { Instantâneo - } \\
\text { DNER* }\end{array}$ & $\begin{array}{c}\text { Módulo } \\
\text { Total - } \\
\text { NCHRP* }\end{array}$ & $\begin{array}{c}\text { Módulo } \\
\text { Instantâneo } \\
\text { Real - } \\
\text { NCHRP* }\end{array}$ \\
\hline \multirow{8}{*}{$100-0-0$} & $1-1 \mathrm{E}$ & 12998 & 20493 & 13526 & 18846 \\
\hline & $2-1 \mathrm{E} 1$ & 14861 & 23110 & 16226 & 22439 \\
\hline & $3-1 \mathrm{E} 1$ & 15781 & 25027 & 16927 & 22795 \\
\hline & $4-1 \mathrm{E}$ & 12276 & 19315 & 13263 & 18044 \\
\hline & $5-1 \mathrm{E}$ & 12793 & 20395 & 13719 & 18628 \\
\hline & $6-1 \mathrm{E}$ & 11269 & 18091 & 12121 & 16262 \\
\hline & $7-1 \mathrm{E} 1$ & 10429 & 16794 & 11064 & 15068 \\
\hline & Média & 12915 & 20461 & 13835 & 18869 \\
\hline \multirow{8}{*}{ 93-0-7 } & $1-2 \mathrm{E}$ & 10717 & 18986 & 11335 & 15718 \\
\hline & $2-2 \mathrm{E}$ & 7997 & 13753 & 8451 & 11602 \\
\hline & $3-2 \mathrm{E}$ & 8812 & 15771 & 9419 & 12909 \\
\hline & $4-2 \mathrm{E}$ & 6392 & 12627 & 6559 & 9325 \\
\hline & $5-2 \mathrm{E}$ & 7718 & 13514 & 8030 & 11198 \\
\hline & $6-2 \mathrm{E}$ & 6594 & 13202 & 6765 & 9606 \\
\hline & $7-2 \mathrm{E}$ & 5796 & 12001 & 6048 & 8499 \\
\hline & Média & 7718 & 14265 & 8087 & 11265 \\
\hline \multirow{8}{*}{ 86-0-14 } & $1-3 \mathrm{E}$ & 4601 & 8491 & 4830 & 6632 \\
\hline & $2-3 \mathrm{E}$ & 4897 & 9372 & 5051 & 7082 \\
\hline & $3-3 \mathrm{E}$ & 5021 & 9657 & 5311 & 7409 \\
\hline & $4-3 \mathrm{E}$ & 4396 & 9277 & 4658 & 6576 \\
\hline & $5-3 E$ & 4970 & 10029 & 5290 & 7381 \\
\hline & $6-3 E$ & 4236 & 7886 & 4411 & 6106 \\
\hline & $7-3 E$ & 4461 & 8496 & 4572 & 6476 \\
\hline & Média & 4655 & 9030 & 4875 & 6809 \\
\hline \multirow{8}{*}{ 91-9-0 } & $1-4 \mathrm{E} 1$ & 12351 & 17552 & 12987 & 17517 \\
\hline & 2-4E1 & 12617 & 18561 & 13319 & 17751 \\
\hline & $3-4 \mathrm{E} 1$ & 12346 & 17561 & 13447 & 17450 \\
\hline & 4-4E1 & 11572 & 16870 & 12197 & 16033 \\
\hline & $5-4 \mathrm{E} 1$ & 12365 & 18068 & 13204 & 17483 \\
\hline & $6-4 \mathrm{E}$ & 12665 & 17772 & 13348 & 17831 \\
\hline & 7-4E1 & 12955 & 19069 & 13461 & 18062 \\
\hline & Média & 12410 & 17922 & 13138 & 17447 \\
\hline
\end{tabular}




\begin{tabular}{|c|c|c|c|c|c|}
\hline & \multicolumn{5}{|c|}{ Teor de 6,5\% } \\
\hline Ligante & Ensaio & $\begin{array}{l}\text { Módulo } \\
\text { Total - } \\
\text { DNER* }\end{array}$ & $\begin{array}{c}\text { Módulo } \\
\text { Instantâneo - } \\
\text { DNER* }\end{array}$ & $\begin{array}{c}\text { Módulo } \\
\text { Total - } \\
\text { NCHRP* }\end{array}$ & $\begin{array}{c}\text { Módulo } \\
\text { Instantâneo } \\
\text { Real - } \\
\text { NCHRP* }\end{array}$ \\
\hline \multirow{8}{*}{ 82-18-0 } & $1-6 \mathrm{E} 1$ & 9197 & 13918 & 9721 & 13009 \\
\hline & $2-6 \mathrm{E} 1$ & 9145 & 13648 & 9678 & 12923 \\
\hline & $3-6 \mathrm{E}$ & 9736 & 14442 & 10520 & 13894 \\
\hline & 4-6E1 & 10784 & 15387 & 11489 & 15089 \\
\hline & $5-6 \mathrm{E}$ & 9985 & 14760 & 10493 & 14175 \\
\hline & $6-6 \mathrm{E}$ & 9416 & 13694 & 10000 & 13341 \\
\hline & $7-6 \mathrm{E} 1$ & 10022 & 15074 & 10545 & 14167 \\
\hline & Média & 9755 & 14418 & 10350 & 13800 \\
\hline \multirow{8}{*}{$77-9-14$} & $1-5 \mathrm{E} 1$ & 6677 & 11257 & 7034 & 9604 \\
\hline & $2-5 \mathrm{E} 1$ & 5690 & 9352 & 5962 & 8118 \\
\hline & $3-5 \mathrm{E} 1$ & 6093 & 9911 & 6464 & 8723 \\
\hline & $4-5 \mathrm{E}$ & 6205 & 10532 & 6509 & 8950 \\
\hline & $5-5 \mathrm{E}$ & 6176 & 10942 & 6377 & 8973 \\
\hline & $6-5 \mathrm{E} 1$ & 6648 & 11284 & 6899 & 9515 \\
\hline & $7-5 \mathrm{E}$ & 6092 & 10277 & 6374 & 8776 \\
\hline & Média & 6226 & 10508 & 6517 & 8951 \\
\hline \multirow{8}{*}{$75-18-7$} & $1-7 \mathrm{E}$ & 6068 & 9183 & 6274 & 8515 \\
\hline & $2-7 \mathrm{E} 1$ & 5500 & 8461 & 5747 & 7793 \\
\hline & $3-7 E$ & 6053 & 8922 & 6194 & 8486 \\
\hline & $4-7 \mathrm{E}$ & 6028 & 9428 & 6251 & 8578 \\
\hline & $5-7 \mathrm{E}$ & 5512 & 8691 & 5801 & 7839 \\
\hline & $6-7 \mathrm{E} 1$ & 5347 & 8294 & 5506 & 7513 \\
\hline & $7-7 E$ & 5891 & 9010 & 6049 & 8294 \\
\hline & Média & 5771 & 8856 & 5974 & 8146 \\
\hline \multirow{8}{*}{$\begin{array}{c}68-18- \\
14\end{array}$} & $1-8 \mathrm{E}$ & 5351 & 8442 & 5526 & 7524 \\
\hline & $2-8 \mathrm{E}$ & 4906 & 7928 & 5015 & 6927 \\
\hline & $3-8 \mathrm{E}$ & 4914 & 7637 & 4956 & 6852 \\
\hline & 4-8E1 & 4854 & 7613 & 4927 & 6822 \\
\hline & $5-8 \mathrm{E}$ & 5155 & 8285 & 5170 & 7138 \\
\hline & $6-8 \mathrm{E}$ & 5466 & 9062 & 5483 & 7794 \\
\hline & $7-8 \mathrm{E} 1$ & 4616 & 6994 & 4584 & 6374 \\
\hline & Média & 5038 & 7994 & 5095 & 7061 \\
\hline
\end{tabular}


Tabela D1: Resistência à tração das misturas estudas

\begin{tabular}{|c|c|c|c|c|c|c|c|}
\hline Ligante & $\begin{array}{c}\text { Corpo-de- } \\
\text { prova }\end{array}$ & Diâmetro & Altura & $\begin{array}{c}\text { Carga } \\
\text { (Kg) }\end{array}$ & $\begin{array}{c}\text { Carga } \\
(\mathrm{N})\end{array}$ & $\begin{array}{c}\text { RT } \\
\text { (Mpa) }\end{array}$ & $\begin{array}{c}\text { Média } \\
\text { RT }\end{array}$ \\
\hline \multirow{10}{*}{$100-0-0$} & $1-1 \mathrm{~A}$ & 10,16 & 6,21 & 2579 & 25300 & 2,55 & \multirow{2}{*}{2,58} \\
\hline & $4-1 \mathrm{~A}$ & 10,19 & 6,19 & 2623 & 25732 & 2,60 & \\
\hline & $5-1 \mathrm{~B}$ & 10,16 & 6,09 & 2790 & 27370 & 2,82 & \multirow{2}{*}{2,66} \\
\hline & $6-1 B$ & 10,17 & 6,12 & 2494 & 24466 & 2,50 & \\
\hline & $2-1 C$ & 10,18 & 6,01 & 2923 & 28675 & 2,99 & \multirow{2}{*}{3,04} \\
\hline & $4-1 \mathrm{C}$ & 10,16 & 6,04 & 3033 & 29754 & 3,09 & \\
\hline & $1-1 \mathrm{D}$ & 10,16 & 5,99 & 2999 & 29420 & 3,08 & \multirow{2}{*}{3,02} \\
\hline & $2-1 \mathrm{D}$ & 10,15 & 5,97 & 2878 & 28233 & 2,97 & \\
\hline & $1-1 \mathrm{E}$ & 10,16 & 5,97 & 2555 & 25065 & 2,63 & \multirow{2}{*}{2,66} \\
\hline & $2-1 E$ & 10,15 & 5,97 & 2607 & 25575 & 2,69 & \\
\hline \multirow{10}{*}{ 93-0-7 } & 60 & & & & 21000 & 200 & \multirow{3}{*}{2,21} \\
\hline & $\frac{0-2 A}{7-2 A}$ & $\frac{10,10}{10 ?}$ & 0,00 & 2242 & 21994 & 2,28 & \\
\hline & $1-2 \mathrm{~B}$ & 1017 & & & & & \\
\hline & $2-2 B$ & 1018 & 504 & 2541 & 24027 & 263 & 2,59 \\
\hline & $2-2 \mathrm{C}$ & 10,18 & 5.99 & 2158 & 21170 & 221 & \multirow[b]{2}{*}{2,26} \\
\hline & $4-2 \mathrm{C}$ & 10,17 & 5,96 & 2243 & 22004 & 2,31 & \\
\hline & $1-2 \mathrm{D}$ & 10,18 & 5,89 & 1745 & 17118 & 1,82 & \multirow{2}{*}{1,80} \\
\hline & $7-2 \mathrm{D}$ & 10,17 & 5,99 & 1743 & 17099 & 1,79 & \\
\hline & $2-2 E$ & 10,16 & 5,92 & 1863 & 18276 & 1,94 & \multirow{2}{*}{1,96} \\
\hline & $6-2 E$ & 10,17 & 5,87 & 1898 & 18619 & 1,99 & \\
\hline \multirow{10}{*}{$86-0-14$} & $4-3 \mathrm{~A}$ & 10,18 & 6,15 & 1453 & 14254 & 1,45 & \multirow{2}{*}{1,48} \\
\hline & $5-3 \mathrm{~A}$ & 10,19 & 6,16 & 1516 & 14872 & 1,51 & \\
\hline & $1-3 B$ & 10,18 & 6,03 & 1642 & 16108 & 1,67 & \multirow{2}{*}{1,62} \\
\hline & $6-3 \mathrm{~B}$ & 10,17 & 6,05 & 1550 & 15206 & 1,57 & \\
\hline & $1-3 \mathrm{C}$ & 10,15 & 5,96 & 1798 & 17638 & 1,86 & \multirow{2}{*}{1,90} \\
\hline & $3-3 \mathrm{C}$ & 10,18 & 5,90 & 1864 & 18286 & 1,94 & \\
\hline & $5-3 \mathrm{D}$ & 10,15 & 5,95 & 1230 & 12066 & 1,27 & \multirow{2}{*}{1,30} \\
\hline & $6-3 \mathrm{D}$ & 10,16 & 5,83 & 1257 & 12331 & 1,33 & \\
\hline & $1-3 \mathrm{E}$ & 10,17 & 5,89 & 1213 & 11900 & 1,27 & \multirow{2}{*}{1,23} \\
\hline & $7-3 \mathrm{E}$ & 10,16 & 5,87 & 1148 & 11262 & 1,20 & \\
\hline \multirow{10}{*}{ 91-9-0 } & $1-4 \mathrm{~A}$ & 10,19 & 6,23 & 2006 & 19679 & 1,97 & \multirow{2}{*}{1,86} \\
\hline & $4-4 \mathrm{~A}$ & 10,17 & 6,28 & 1790 & 17560 & 1,75 & \\
\hline & $4-4 B$ & 10,16 & 6,18 & 2184 & 21425 & 2,17 & \multirow{2}{*}{2,39} \\
\hline & $7-4 B$ & 10,18 & 6,04 & 2563 & 25143 & 2,60 & \\
\hline & $1-4 \mathrm{C}$ & 10,17 & 6,11 & 2415 & 23691 & 2,43 & \multirow{2}{*}{2,30} \\
\hline & $5-4 \mathrm{C}$ & 10,19 & 6,14 & 2180 & 21386 & 2,18 & \\
\hline & $1-4 \mathrm{D}$ & 10,16 & 5,97 & 2840 & 27860 & 2,93 & \multirow{2}{*}{2,97} \\
\hline & $6-4 \mathrm{D}$ & 10,15 & 5,93 & 2899 & 28439 & 3,01 & \\
\hline & $1-4 \mathrm{E}$ & 10,17 & 6,07 & 2472 & 24250 & 2,50 & \multirow{2}{*}{2,45} \\
\hline & $5-4 \mathrm{E}$ & 10,17 & 6,07 & 2373 & 23279 & 2,40 & \\
\hline
\end{tabular}




\begin{tabular}{|c|c|c|c|c|c|c|c|}
\hline Ligante & $\begin{array}{c}\text { Corpo-de- } \\
\text { prova }\end{array}$ & Diâmetro & Altura & $\begin{array}{c}\text { Carga } \\
(\mathrm{Kg})\end{array}$ & $\begin{array}{c}\text { Carga } \\
(\mathrm{N}) \\
\end{array}$ & $\begin{array}{c}\text { RT } \\
\text { (Mpa) }\end{array}$ & $\begin{array}{c}\text { Média } \\
\text { RT }\end{array}$ \\
\hline \multirow{10}{*}{$77-9-14$} & $1-5 \mathrm{~A}$ & 10,18 & 6,11 & 1929 & 18923 & 1,94 & \multirow{2}{*}{1,93} \\
\hline & $6-5 \mathrm{~A}$ & 10,17 & 6,07 & 1890 & 18541 & 1,91 & \\
\hline & $2-5 B$ & 10,16 & 6,04 & 1832 & 17972 & 1,87 & \multirow{2}{*}{1,92} \\
\hline & $4-5 B$ & 10,16 & 5,88 & 1891 & 18551 & 1,98 & \\
\hline & $2-5 \mathrm{C}$ & 10,17 & 5,93 & 1752 & 17187 & 1,82 & \multirow{2}{*}{1,83} \\
\hline & $7-5 \mathrm{C}$ & 10,16 & 6,03 & 1816 & 17815 & 1,85 & \\
\hline & $1-5 \mathrm{D}$ & 10,16 & 5,94 & 1761 & 17275 & 1,82 & \multirow{2}{*}{1,81} \\
\hline & $2-5 \mathrm{D}$ & 10,15 & 5,95 & 1743 & 17099 & 1,80 & \\
\hline & $6-5 \mathrm{E}$ & 10,17 & 5,94 & 1621 & 15902 & 1,68 & \multirow{2}{*}{1,65} \\
\hline & $7-5 \mathrm{E}$ & 10,16 & 6,00 & 1587 & 15568 & 1,63 & \\
\hline & & & & & 0 & & \\
\hline \multirow{10}{*}{ 82-0-18 } & $3-6 \mathrm{~A}$ & 10,18 & 6,20 & 2029 & 19904 & 2,01 & \multirow{2}{*}{2,18} \\
\hline & $4-6 \mathrm{~A}$ & 10,2 & 6,15 & 2359 & 23142 & 2,35 & \\
\hline & $2-6 \mathrm{~B}$ & 10,17 & 6,14 & 2077 & 20375 & 2,08 & \multirow{2}{*}{2,01} \\
\hline & $7-6 \mathrm{~B}$ & 10,18 & 6,20 & 1958 & 19208 & 1,94 & \\
\hline & $3-6 \mathrm{C}$ & 10,18 & 6,04 & 2852 & 27978 & 2,90 & \multirow{2}{*}{2,59} \\
\hline & $7-6 \mathrm{C}$ & 10,16 & 6,18 & 2289 & 22455 & 2,28 & \\
\hline & $3-6 \mathrm{D}$ & 10,17 & 6,02 & 2866 & 28115 & 2,93 & \multirow{2}{*}{2,72} \\
\hline & $4-6 \mathrm{D}$ & 10,16 & 6,08 & 2484 & 24368 & 2,51 & \\
\hline & $3-6 \mathrm{E}$ & 10,16 & 6,11 & 2193 & 21513 & 2,21 & \multirow{2}{*}{2,13} \\
\hline & $5-6 \mathrm{E}$ & 10,17 & 6,10 & 2037 & 19983 & 2,05 & \\
\hline \multirow{10}{*}{ 75-18-7 } & $1-7 \mathrm{~A}$ & 10,19 & 6,17 & 1890 & 18541 & 1,88 & \multirow{2}{*}{2,03} \\
\hline & $6-7 \mathrm{~A}$ & 10,19 & 6,12 & 2186 & 21445 & 2,19 & \\
\hline & $3-7 \mathrm{~B}$ & 10,17 & 6,02 & 2328 & 22838 & 2,38 & \multirow{2}{*}{2,28} \\
\hline & $4-7 \mathrm{~B}$ & 10,18 & 6,05 & 2158 & 21170 & 2,19 & \\
\hline & $2-7 \mathrm{C}$ & 10,18 & 6,13 & 1892 & 18561 & 1,89 & \multirow{2}{*}{1,98} \\
\hline & $6-7 \mathrm{C}$ & 10,17 & 6,08 & 2047 & 20081 & 2,07 & \\
\hline & $6-7 \mathrm{D}$ & 10,16 & 6,05 & 2211 & 21690 & 2,25 & \multirow{2}{*}{2,15} \\
\hline & $7-7 \mathrm{D}$ & 10,15 & 6,12 & 2044 & 20052 & 2,06 & \\
\hline & $5-7 \mathrm{E}$ & 10,16 & 6,08 & 1547 & 15176 & 1,56 & \multirow{2}{*}{1,60} \\
\hline & $7-7 \mathrm{E}$ & 10,15 & 6,08 & 1609 & 15784 & 1,63 & \\
\hline \multirow{10}{*}{ 68-18-14 } & $1-8 \mathrm{~A}$ & 10,18 & 6,30 & 1036 & 10163 & 1,01 & \multirow{2}{*}{1,03} \\
\hline & $2-8 \mathrm{~A}$ & 10,16 & 6,30 & 1071 & 10507 & 1,05 & \\
\hline & $1-8 \mathrm{~B}$ & 10,18 & 6,24 & 1165 & 11429 & 1,15 & \multirow{2}{*}{1,12} \\
\hline & $5-8 \mathrm{~B}$ & 10,18 & 6,26 & 1115 & 10938 & 1,09 & \\
\hline & $2-8 \mathrm{C}$ & 10,16 & 6,20 & 1278 & 12537 & 1,27 & \multirow{2}{*}{1,25} \\
\hline & $5-8 \mathrm{C}$ & 10,17 & 6,21 & 1242 & 12184 & 1,23 & \\
\hline & $1-8 \mathrm{D}$ & 10,17 & 6,14 & 1477 & 14489 & 1,48 & \multirow{2}{*}{1,42} \\
\hline & $4-8 \mathrm{D}$ & 10,17 & 6,16 & 1372 & 13459 & 1,37 & \\
\hline & $5-8 \mathrm{E}$ & 10,17 & 6,08 & 1279 & 12547 & 1,29 & \multirow{2}{*}{1,22} \\
\hline & $6-8 \mathrm{E}$ & 10,14 & 6,11 & 1145 & 11232 & 1,15 & \\
\hline
\end{tabular}


APÊNDICE E 
Tabela E1: MR/RT das misturas estudas

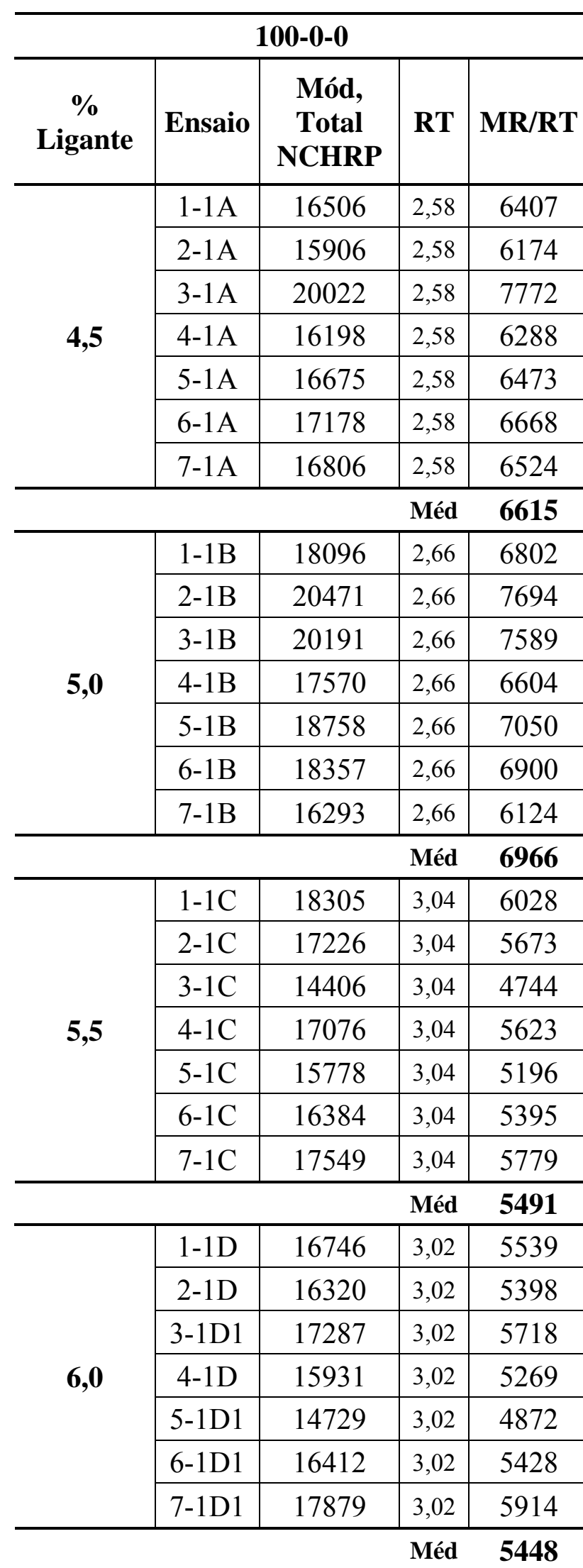

\begin{tabular}{|c|c|c|c|c|}
\hline \multicolumn{5}{|c|}{ 93-0-7 } \\
\hline $\begin{array}{c}\% \\
\text { Ligante }\end{array}$ & Ensaio & $\begin{array}{c}\text { Mód, } \\
\text { Total } \\
\text { NCHRP }\end{array}$ & RT & $\begin{array}{c}\text { MR/ } \\
\text { RT }\end{array}$ \\
\hline \multirow{7}{*}{4,5} & $1-2 \mathrm{~A}$ & 12466 & 2,21 & 5641 \\
\hline & $2-2 \mathrm{~A}$ & 13349 & 2,21 & 6040 \\
\hline & $3-2 \mathrm{~A}$ & 12015 & 2,21 & 5437 \\
\hline & $4-2 \mathrm{~A}$ & 13007 & 2,21 & 5885 \\
\hline & $5-2 A$ & 15732 & 2,21 & 7119 \\
\hline & $6-2 A$ & 11826 & 2,21 & 5351 \\
\hline & $7-2 \mathrm{~A}$ & 11550 & 2,21 & 5226 \\
\hline \multicolumn{5}{|c|}{ Méd } \\
\hline \multirow{7}{*}{5,0} & $1-2 \mathrm{~B} 1$ & 12723 & 2,59 & 4912 \\
\hline & $2-2 B$ & 13232 & 2,59 & 5109 \\
\hline & $3-2 B$ & 13092 & 2,59 & 5055 \\
\hline & $4-2 B$ & 13014 & 2,59 & 5025 \\
\hline & $5-2 B$ & 11637 & 2,59 & 4493 \\
\hline & $6-2 \mathrm{~B} 1$ & 11687 & 2,59 & 4512 \\
\hline & $7-2 B$ & 11043 & 2,59 & 4264 \\
\hline \multicolumn{5}{|r|}{4767} \\
\hline \multirow{7}{*}{5,5} & $1-2 C$ & 10497 & 2,26 & 4645 \\
\hline & $2-2 \mathrm{C}$ & 11555 & 2,26 & 5113 \\
\hline & $3-2 C$ & 9908 & 2,26 & 4384 \\
\hline & $4-2 \mathrm{C} 1$ & 10391 & 2,26 & 4598 \\
\hline & $5-2 \mathrm{C}$ & 8628 & 2,26 & 3818 \\
\hline & $6-2 \mathrm{C}$ & 12103 & 2,26 & 5355 \\
\hline & $7-2 C$ & 9420 & 2,26 & 4168 \\
\hline \multicolumn{5}{|c|}{ Méd } \\
\hline \multirow{7}{*}{6,0} & $1-2 D$ & 8723 & 1,80 & 4846 \\
\hline & $2-2 D$ & 8784 & 1,80 & 4880 \\
\hline & $3-2 D$ & 11088 & 1,80 & 6160 \\
\hline & $4-2 \mathrm{D}$ & 6289 & 1,80 & 3494 \\
\hline & $5-2 \mathrm{D}$ & 7503 & 1,80 & 4168 \\
\hline & 6-2D1 & 8811 & 1,80 & 4895 \\
\hline & $7-2 \mathrm{D}$ & 7676 & 1,80 & 4264 \\
\hline
\end{tabular}




\begin{tabular}{c|c|c|c|c}
\hline \multicolumn{5}{|c}{$\mathbf{1 0 0 - 0 - 0}$} \\
\hline \multirow{4}{*}{ \% Ligante } & Ensaio & $\begin{array}{c}\text { Mód, Total } \\
\text { NCHRP }\end{array}$ & RT & MR/RT \\
\hline \multirow{5}{*}{$\mathbf{6 , 5}$} & 1-1E & 13526 & 2,88 & 4694 \\
\cline { 2 - 5 } & 2-1E1 & 16226 & 2,88 & 5632 \\
\cline { 2 - 5 } & $3-1 \mathrm{E} 1$ & 16927 & 2,88 & 5875 \\
\cline { 2 - 5 } & $4-1 \mathrm{E} 1$ & 13263 & 2,88 & 4603 \\
\cline { 2 - 5 } & $5-1 \mathrm{E}$ & 13719 & 2,88 & 4762 \\
\cline { 2 - 5 } & $6-1 \mathrm{E}$ & 12121 & 2,88 & 4207 \\
\cline { 2 - 5 } & $7-1 \mathrm{E} 1$ & 11064 & 2,88 & 3840 \\
\hline
\end{tabular}

Méd 4802

\begin{tabular}{|c|c|c|c|c|}
\hline \multicolumn{5}{|c|}{$86-0-14$} \\
\hline$\%$ Ligante & Ensaio & $\begin{array}{c}\text { Mód, } \\
\text { Total } \\
\text { NCHRP }\end{array}$ & RT & MR/RT \\
\hline \multirow{7}{*}{4,5} & $1-3 \mathrm{~A}$ & 7668 & 1,48 & 5181 \\
\hline & $2-3 A$ & 6053 & 1,48 & 4090 \\
\hline & $3-3 \mathrm{~A}$ & 6950 & 1,48 & 4696 \\
\hline & $4-3 \mathrm{~A}$ & 7000 & 1,48 & 4730 \\
\hline & $5-3 \mathrm{~A}$ & 7654 & 1,48 & 5171 \\
\hline & $6-3 \mathrm{~A}$ & 7897 & 1,48 & 5336 \\
\hline & $7-3 \mathrm{~A}$ & 6664 & 1,48 & 4503 \\
\hline \multicolumn{5}{|c|}{ Méd } \\
\hline \multirow{7}{*}{5,0} & $1-3 B$ & 7115 & 1,62 & 4392 \\
\hline & $2-3 B$ & 7519 & 1,62 & 4641 \\
\hline & $3-3 B$ & 8089 & 1,62 & 4993 \\
\hline & $4-3 \mathrm{~B}$ & 6886 & 1,62 & 4251 \\
\hline & $5-3 \mathrm{~B}$ & 7388 & 1,62 & 4561 \\
\hline & $6-3 \mathrm{~B}$ & 6978 & 1,62 & 4307 \\
\hline & $7-3 B$ & 6537 & 1,62 & 4035 \\
\hline \multicolumn{5}{|c|}{ Médi } \\
\hline \multirow{5}{*}{5,5} & $1-3 C$ & 7352 & 1,90 & 3869 \\
\hline & $2-3 C$ & 6988 & 1,90 & 3678 \\
\hline & $3-3 C$ & 7112 & 1,90 & 3743 \\
\hline & $4-3 C$ & 7632 & 1,90 & 4017 \\
\hline & $5-3 C$ & 6622 & 1,90 & 3485 \\
\hline
\end{tabular}

\begin{tabular}{|c|c|c|c|c|}
\hline \multicolumn{5}{|c|}{$93-0-7$} \\
\hline $\begin{array}{c}\% \\
\text { Ligante }\end{array}$ & Ensaio & $\begin{array}{l}\text { Mód, Total } \\
\text { NCHRP }\end{array}$ & RT & $\begin{array}{c}\mathrm{MR} / \mathrm{R} \\
\mathrm{T}\end{array}$ \\
\hline \multirow{7}{*}{6,5} & $1-2 \mathrm{E}$ & 11335 & 1,96 & 5783 \\
\hline & $2-2 \mathrm{E}$ & 8451 & 1,96 & 4312 \\
\hline & $3-2 \mathrm{E}$ & 9419 & 1,96 & 4805 \\
\hline & $4-2 \mathrm{E}$ & 6559 & 1,96 & 3346 \\
\hline & $5-2 \mathrm{E}$ & 8030 & 1,96 & 4097 \\
\hline & $6-2 \mathrm{E}$ & 6765 & 1,96 & 3452 \\
\hline & $7-2 \mathrm{E}$ & 6048 & 1,96 & 3086 \\
\hline
\end{tabular}

\begin{tabular}{|c|c|c|c|c|}
\hline \multicolumn{5}{|c|}{ 91-9-0 } \\
\hline $\begin{array}{c}\% \\
\text { Ligante }\end{array}$ & Ensaio & $\begin{array}{c}\text { Mód, } \\
\text { Total } \\
\text { NCHRP }\end{array}$ & RT & MR/RT \\
\hline \multirow{7}{*}{4,5} & $1-4 \mathrm{~A}$ & 11845 & 1,86 & 6368 \\
\hline & $2-4 \mathrm{~A}$ & 13238 & 1,86 & 7117 \\
\hline & $3-4 \mathrm{~A}$ & 11996 & 1,86 & 6449 \\
\hline & $4-4 \mathrm{~A}$ & 11448 & 1,86 & 6155 \\
\hline & $5-4 \mathrm{~A}$ & 13793 & 1,86 & 7415 \\
\hline & $6-4 \mathrm{~A}$ & 14808 & 1,86 & 7961 \\
\hline & $7-4 \mathrm{~A}$ & 11540 & 1,86 & 6204 \\
\hline \multicolumn{5}{|c|}{ Média } \\
\hline \multirow{7}{*}{5,0} & 1-4B & 17635 & 2,39 & 7379 \\
\hline & $2-4 B$ & 16538 & 2,39 & 6920 \\
\hline & $3-4 \mathrm{~B} 1$ & 16484 & 2,39 & 6897 \\
\hline & 4-4B1 & 15052 & 2,39 & 6298 \\
\hline & $5-4 \mathrm{~B}$ & 16650 & 2,39 & 6966 \\
\hline & $6-4 \mathrm{~B} 1$ & 17715 & 2,39 & 7412 \\
\hline & 7-4B1 & 16265 & 2,39 & 6805 \\
\hline \multicolumn{5}{|c|}{ Média } \\
\hline \multirow{5}{*}{5,5} & $1-4 \mathrm{C} 1$ & 14770 & 2,30 & 6422 \\
\hline & $2-4 \mathrm{C}$ & 14945 & 2,30 & 6498 \\
\hline & $3-4 \mathrm{C}$ & 14131 & 2,30 & 6144 \\
\hline & $4-4 \mathrm{C} 1$ & 16645 & 2,30 & 7237 \\
\hline & $5-4 \mathrm{C} 1$ & 14783 & 2,30 & 6428 \\
\hline
\end{tabular}




\begin{tabular}{|c|c|c|c|c|}
\hline & $6-3 \mathrm{C}$ & 6909 & 1,90 & 3636 \\
\hline & $7-3 \mathrm{C}$ & 6567 & 1,90 & 3456 \\
\hline & & \multicolumn{2}{|r|}{ Média } & 3698 \\
\hline \multirow{7}{*}{6,0} & $1-3 \mathrm{D}$ & 3634 & 1,30 & 2795 \\
\hline & $2-3 D$ & 4466 & 1,30 & 3436 \\
\hline & $3-3 D$ & 3734 & 1,30 & 2872 \\
\hline & $4-3 D$ & 4165 & 1,30 & 3204 \\
\hline & $5-3 \mathrm{D}$ & 4453 & 1,30 & 3425 \\
\hline & $6-3 \mathrm{D}$ & 4309 & 1,30 & 3315 \\
\hline & $7-3 \mathrm{D}$ & 4422 & 1,30 & 3402 \\
\hline \multicolumn{4}{|r|}{ Média } & 3207 \\
\hline \multirow{7}{*}{6,5} & $1-3 E$ & 4830 & 1,23 & 3927 \\
\hline & $2-3 E$ & 5051 & 1,23 & 4107 \\
\hline & $3-3 E$ & 5311 & 1,23 & 4318 \\
\hline & $4-3 \mathrm{E}$ & 4658 & 1,23 & 3787 \\
\hline & $5-3 \mathrm{E}$ & 5290 & 1,23 & 4300 \\
\hline & $6-3 E$ & 4411 & 1,23 & 3586 \\
\hline & $7-3 E$ & 4572 & 1,23 & 3717 \\
\hline
\end{tabular}

\begin{tabular}{|c|c|c|c|c|}
\hline & $6-4 \mathrm{C} 1$ & 15046 & 2,30 & 6542 \\
\hline & $7-4 \mathrm{Cl}$ & 14184 & 2,30 & 6167 \\
\hline \multicolumn{4}{|r|}{ Média } & 6491 \\
\hline \multirow{7}{*}{6,0} & $1-4 \mathrm{D}$ & 15308 & 2,97 & 5154 \\
\hline & $2-4 \mathrm{D}$ & 13839 & 2,97 & 4660 \\
\hline & $3-4 \mathrm{D} 1$ & 13553 & 2,97 & 4563 \\
\hline & $4-4 \mathrm{D}$ & 14010 & 2,97 & 4717 \\
\hline & $5-4 \mathrm{D}$ & 15378 & 2,97 & 5178 \\
\hline & $6-4 \mathrm{D}$ & 14885 & 2,97 & 5012 \\
\hline & $7-4 \mathrm{D}$ & 16032 & 2,97 & 5398 \\
\hline \multicolumn{5}{|c|}{ Média } \\
\hline \multirow{7}{*}{6,5} & $1-4 \mathrm{E}$ & 12987 & 2,45 & 5301 \\
\hline & 2-4E1 & 13319 & 2,45 & 5436 \\
\hline & $3-4 \mathrm{E} 1$ & 13447 & 2,45 & 5488 \\
\hline & 4-4E1 & 12197 & 2,45 & 4979 \\
\hline & $5-4 \mathrm{E} 1$ & 13204 & 2,45 & 5390 \\
\hline & $6-4 \mathrm{E}$ & 13348 & 2,45 & 5448 \\
\hline & $7-4 \mathrm{E} 1$ & 13461 & 2,45 & 5494 \\
\hline
\end{tabular}

\begin{tabular}{|c|c|c|c|c|}
\hline \multicolumn{5}{|c|}{ 77-9-14 } \\
\hline $\begin{array}{c}\% \\
\text { Ligante }\end{array}$ & Ensaio & $\begin{array}{l}\text { Mód, Total } \\
\text { NCHRP }\end{array}$ & RT & MR/RT \\
\hline \multirow{7}{*}{4,5} & $1-5 \mathrm{~A} 1$ & 12229 & 1,93 & 6336 \\
\hline & $2-5 \mathrm{~A} 1$ & 10836 & 1,93 & 5615 \\
\hline & $3-5 A$ & 13257 & 1,93 & 6869 \\
\hline & $4-5 \mathrm{~A}$ & 12275 & 1,93 & 6360 \\
\hline & $5-5 \mathrm{~A}$ & 12134 & 1,93 & 6287 \\
\hline & $6-5 \mathrm{~A} 1$ & 11707 & 1,93 & 6066 \\
\hline & $7-5 \mathrm{~A} 1$ & 9469 & 1,93 & 4906 \\
\hline \multicolumn{4}{|r|}{ Média } & 6063 \\
\hline \multirow{7}{*}{5,0} & $1-5 B$ & 10433 & 1,92 & 5434 \\
\hline & $2-5 B$ & 9232 & 1,92 & 4808 \\
\hline & $3-5 B$ & 10435 & 1,92 & 5435 \\
\hline & $4-5 \mathrm{~B} 1$ & 10706 & 1,92 & 5576 \\
\hline & $5-5 \mathrm{~B} 1$ & 11784 & 1,92 & 6138 \\
\hline & $6-5 \mathrm{~B} 1$ & 9309 & 1,92 & 4849 \\
\hline & $7-5 \mathrm{~B} 1$ & 10275 & 1,92 & 5352 \\
\hline
\end{tabular}

\begin{tabular}{c|c|c|c|c}
\hline \multicolumn{5}{|c}{ 82-18-0 } \\
\hline $\begin{array}{c}\text { \% } \\
\text { Ligante }\end{array}$ & Ensaio & $\begin{array}{c}\text { Mód, } \\
\text { Total } \\
\text { NCHRP }\end{array}$ & RT & MR/RT \\
\hline \multirow{4}{*}{4,5} & 1-6A & 11738 & 2,18 & 5384 \\
\cline { 2 - 5 } & 2-6A & 10871 & 2,18 & 4987 \\
\cline { 2 - 5 } & 3-6A1 & 13342 & 2,18 & 6120 \\
\cline { 2 - 5 } & 4-6A & 17156 & 2,18 & 7870 \\
\cline { 2 - 5 } & 5-6A1 & 19156 & 2,18 & 8787 \\
\cline { 2 - 5 } & 6-6A & 19046 & 2,18 & 8737 \\
\cline { 2 - 6 } & 7-6A1 & 18585 & 2,18 & 8525 \\
\hline
\end{tabular}

Média 7201

\begin{tabular}{c|c|c|c|c}
\hline \multirow{4}{*}{5,0} & 1-6B1 & 11600 & 2,01 & 5771 \\
\cline { 2 - 5 } & 2-6B & 10517 & 2,01 & 5232 \\
\cline { 2 - 5 } & 3-6B & 9960 & 2,01 & 4955 \\
\cline { 2 - 5 } & 4-6B1 & 11221 & 2,01 & 5582 \\
\cline { 2 - 5 } & $5-6 \mathrm{~B}$ & 9514 & 2,01 & 4733 \\
\hline & 6-6B & 12406 & 2,01 & 6172 \\
\hline & 7-6B1 & 10990 & 2,01 & 5468 \\
\hline
\end{tabular}


Média 5370

\begin{tabular}{|c|c|c|c|c|}
\hline \multicolumn{5}{|c|}{ 77-9-14 } \\
\hline $\begin{array}{c}\% \\
\text { Ligante }\end{array}$ & Ensaio & $\begin{array}{l}\text { Mód, Total } \\
\text { NCHRP }\end{array}$ & RT & MR/RT \\
\hline \multirow{7}{*}{5,5} & $1-5 \mathrm{C}$ & 7992 & 1,83 & 4367 \\
\hline & $2-5 \mathrm{C} 1$ & 10314 & 1,83 & 5636 \\
\hline & $3-5 C$ & 8387 & 1,83 & 4583 \\
\hline & $4-5 \mathrm{C}$ & 9764 & 1,83 & 5335 \\
\hline & $5-5 \mathrm{C} 1$ & 9194 & 1,83 & 5024 \\
\hline & $6-5 \mathrm{C} 1$ & 9880 & 1,83 & 5399 \\
\hline & $7-5 \mathrm{C} 1$ & 9679 & 1,83 & 5289 \\
\hline \multicolumn{5}{|c|}{ Média } \\
\hline \multirow{7}{*}{6,0} & 1-5D1 & 7867 & 1,81 & 4346 \\
\hline & 2-5D1 & 7783 & 1,81 & 4300 \\
\hline & $3-5 \mathrm{D} 1$ & 7492 & 1,81 & 4139 \\
\hline & $4-5 \mathrm{D}$ & 6871 & 1,81 & 3796 \\
\hline & $5-5 \mathrm{D}$ & 7164 & 1,81 & 3958 \\
\hline & $6-5 \mathrm{D} 1$ & 7446 & 1,81 & 4114 \\
\hline & $7-5 \mathrm{D}$ & 6931 & 1,81 & 3829 \\
\hline \multicolumn{5}{|c|}{ Média } \\
\hline \multirow{7}{*}{6,5} & $1-5 \mathrm{E}$ & 7034 & 1,65 & 4263 \\
\hline & $2-5 \mathrm{E}$ & 5962 & 1,65 & 3613 \\
\hline & $3-5 \mathrm{E}$ & 6464 & 1,65 & 3918 \\
\hline & $4-5 \mathrm{E} 1$ & 6509 & 1,65 & 3945 \\
\hline & $5-5 \mathrm{E} 1$ & 6377 & 1,65 & 3865 \\
\hline & $6-5 \mathrm{E}$ & 6899 & 1,65 & 4181 \\
\hline & $7-5 \mathrm{E}$ & 6374 & 1,65 & 3863 \\
\hline \multicolumn{5}{|c|}{ Média } \\
\hline \multicolumn{5}{|c|}{ 77-18-7 } \\
\hline $\begin{array}{c}\% \\
\text { Ligante }\end{array}$ & Ensaio & $\begin{array}{l}\text { Mód, Total } \\
\text { NCHRP }\end{array}$ & RT & MR/RT \\
\hline \multirow{7}{*}{4,5} & 1-7A1 & 11424 & 2,03 & 5628 \\
\hline & $2-7 \mathrm{~A} 1$ & 12172 & 2,03 & 5996 \\
\hline & 3-7A1 & 13199 & 2,03 & 6502 \\
\hline & $4-7 \mathrm{~A}$ & 9846 & 2,03 & 4850 \\
\hline & 5-7A1 & 12145 & 2,03 & 5983 \\
\hline & 6-7A1 & 12538 & 2,03 & 6177 \\
\hline & 7-7A1 & 9371 & 2,03 & 4616 \\
\hline
\end{tabular}

Média 5416

\begin{tabular}{|c|c|c|c|c|}
\hline \multicolumn{5}{|c|}{ 82-18-0 } \\
\hline $\begin{array}{c}\% \\
\text { Ligante }\end{array}$ & Ensaio & $\begin{array}{c}\text { Mód, } \\
\text { Total } \\
\text { NCHRP }\end{array}$ & RT & MR/RT \\
\hline \multirow{7}{*}{5,5} & $1-6 \mathrm{C} 1$ & 14669 & 2,59 & 5664 \\
\hline & $2-6 C$ & 15225 & 2,59 & 5879 \\
\hline & $3-6 \mathrm{C} 1$ & 14656 & 2,59 & 5659 \\
\hline & $4-6 \mathrm{C} 1$ & 12984 & 2,59 & 5013 \\
\hline & $5-6 \mathrm{C}$ & 15335 & 2,59 & 5921 \\
\hline & $6-6 \mathrm{C} 1$ & 16915 & 2,59 & 6531 \\
\hline & $7-6 C$ & 12585 & 2,59 & 4859 \\
\hline \multicolumn{4}{|r|}{ Média } & 5646 \\
\hline \multirow{7}{*}{6,0} & 1-6D1 & 16367 & 2,72 & 6017 \\
\hline & $2-6 \mathrm{D} 1$ & 12829 & 2,72 & 4717 \\
\hline & $3-6 \mathrm{D} 1$ & 12818 & 2,72 & 4713 \\
\hline & $4-6 \mathrm{D} 1$ & 11984 & 2,72 & 4406 \\
\hline & $5-6 \mathrm{D}$ & 12342 & 2,72 & 4537 \\
\hline & 6-6D & 12083 & 2,72 & 4442 \\
\hline & 7-6D1 & 11004 & 2,72 & 4046 \\
\hline \multicolumn{4}{|r|}{ Média } & 4697 \\
\hline \multirow{7}{*}{6,5} & 1-6E1 & 9721 & 2,13 & 4564 \\
\hline & 2-6E1 & 9678 & 2,13 & 4544 \\
\hline & $3-6 \mathrm{E}$ & 10520 & 2,13 & 4939 \\
\hline & 4-6Е1 & 11489 & 2,13 & 5394 \\
\hline & $5-6 \mathrm{E}$ & 10493 & 2,13 & 4926 \\
\hline & $6-6 \mathrm{E}$ & 10000 & 2,13 & 4695 \\
\hline & 7-6E1 & 10545 & 2,13 & 4951 \\
\hline & & & Média & 4859 \\
\hline
\end{tabular}

68-18-14

\begin{tabular}{c|c|c|c|c}
\hline $\begin{array}{c}\text { \% } \\
\text { Ligante }\end{array}$ & Ensaio & $\begin{array}{c}\text { Mód, } \\
\text { Total } \\
\text { NCHRP }\end{array}$ & RT & MR/RT \\
\hline \multirow{4}{*}{4,5} & $1-8 \mathrm{~A} 1$ & 5079 & 1,03 & 4931 \\
\cline { 2 - 5 } & 2-8A & 5150 & 1,03 & 5000 \\
\cline { 2 - 5 } & 3-8A & 6275 & 1,03 & 6092 \\
\cline { 2 - 5 } & 4-8A & 4975 & 1,03 & 4830 \\
\cline { 2 - 5 } & 5-8A & 6112 & 1,03 & 5933 \\
\cline { 2 - 5 } & 6-8A & 6052 & 1,03 & 5876 \\
\cline { 2 - 5 } & 7-8A & 4887 & 1,03 & 4745 \\
\hline
\end{tabular}


Média 5679

Média

5344

\begin{tabular}{|c|c|c|c|c|}
\hline \multicolumn{5}{|c|}{ 77-18-7 } \\
\hline $\begin{array}{c}\% \\
\text { Ligante }\end{array}$ & Ensaio & $\begin{array}{l}\text { Mód, Total } \\
\text { NCHRP }\end{array}$ & RT & MR/RT \\
\hline \multirow{7}{*}{5,0} & $1-7 \mathrm{~B}$ & 10810 & 2,28 & 4741 \\
\hline & 2-7B1 & 10622 & 2,28 & 4659 \\
\hline & $3-7 B$ & 8882 & 2,28 & 3896 \\
\hline & $4-7 \mathrm{~B}$ & 10429 & 2,28 & 4574 \\
\hline & $5-7 \mathrm{~B}$ & 9700 & 2,28 & 4254 \\
\hline & $6-7 \mathrm{~B}$ & 8812 & 2,28 & 3865 \\
\hline & 7-7B1 & 9433 & 2,28 & 4137 \\
\hline \multicolumn{4}{|r|}{ Média } & 4304 \\
\hline \multirow{7}{*}{5,5} & $1-7 \mathrm{C} 1$ & 8570 & 1,98 & 4328 \\
\hline & $2-7 \mathrm{C} 1$ & 8016 & 1,98 & 4048 \\
\hline & $3-7 \mathrm{C} 1$ & 8309 & 1,98 & 4196 \\
\hline & $4-7 \mathrm{C} 1$ & 9265 & 1,98 & 4679 \\
\hline & $5-7 \mathrm{C}$ & 10449 & 1,98 & 5277 \\
\hline & $6-7 \mathrm{C}$ & 8131 & 1,98 & 4107 \\
\hline & $7-7 \mathrm{C} 1$ & 9125 & 1,98 & 4609 \\
\hline \multicolumn{4}{|r|}{ Média } & 4463 \\
\hline \multirow{7}{*}{6,0} & $1-7 \mathrm{D} 1$ & 10188 & 2,15 & 4739 \\
\hline & $2-7 \mathrm{D}$ & 12088 & 2,15 & 5622 \\
\hline & 3-7D & 9461 & 2,15 & 4400 \\
\hline & 4-7D & 9305 & 2,15 & 4328 \\
\hline & 5-7D & 11692 & 2,15 & 5438 \\
\hline & $6-7 \mathrm{D}$ & 10171 & 2,15 & 4731 \\
\hline & 7-7D1 & 8991 & 2,15 & 4182 \\
\hline \multicolumn{4}{|r|}{ Média } & 4777 \\
\hline \multirow{7}{*}{6,5} & $1-7 \mathrm{E}$ & 6274 & 1,60 & 3921 \\
\hline & 2-7E1 & 5747 & 1,60 & 3592 \\
\hline & $3-7 \mathrm{E}$ & 6194 & 1,60 & 3871 \\
\hline & 4-7E1 & 6251 & 1,60 & 3907 \\
\hline & $5-7 \mathrm{E}$ & 5801 & 1,60 & 3625 \\
\hline & $6-7 \mathrm{E}$ & 5506 & 1,60 & 3441 \\
\hline & $7-7 E$ & 6049 & 1,60 & 3781 \\
\hline
\end{tabular}

\begin{tabular}{|c|c|c|c|c|}
\hline \multicolumn{5}{|c|}{$68-18-14$} \\
\hline $\begin{array}{c}\% \\
\text { Ligante }\end{array}$ & Ensaio & $\begin{array}{c}\text { Mód, } \\
\text { Total } \\
\text { NCHRP }\end{array}$ & RT & MR/RT \\
\hline \multirow{7}{*}{5,0} & $1-8 \mathrm{~B} 1$ & 4613 & 1,12 & 4118 \\
\hline & $2-8 \mathrm{~B}$ & 4873 & 1,12 & 4350 \\
\hline & $3-8 \mathrm{~B} 1$ & 4510 & 1,12 & 4027 \\
\hline & $4-8 \mathrm{~B}$ & 4630 & 1,12 & 4134 \\
\hline & $5-8 \mathrm{~B} 1$ & 4637 & 1,12 & 4140 \\
\hline & 6-8B1 & 4613 & 1,12 & 4118 \\
\hline & $7-8 \mathrm{~B} 1$ & 4770 & 1,12 & 4259 \\
\hline \multicolumn{4}{|r|}{ Média } & 4164 \\
\hline \multirow{7}{*}{5,5} & $1-8 \mathrm{C} 1$ & 6368 & 1,25 & 5094 \\
\hline & $2-8 C$ & 6005 & 1,25 & 4804 \\
\hline & $3-8 \mathrm{C}$ & 6163 & 1,25 & 4930 \\
\hline & $4-8 \mathrm{C} 1$ & 6460 & 1,25 & 5168 \\
\hline & $5-8 \mathrm{C} 1$ & 5518 & 1,25 & 4414 \\
\hline & $6-8 \mathrm{C} 1$ & 4838 & 1,25 & 3870 \\
\hline & $7-8 \mathrm{C}$ & 4777 & 1,25 & 3821 \\
\hline \multicolumn{4}{|r|}{ Média } & 4586 \\
\hline \multirow{7}{*}{6,0} & $1-8 \mathrm{D}$ & 7867 & 1,42 & 5540 \\
\hline & $2-8 \mathrm{D} 1$ & 6881 & 1,42 & 4846 \\
\hline & $3-8 \mathrm{D} 1$ & 7967 & 1,42 & 5611 \\
\hline & $4-8 \mathrm{D} 1$ & 5491 & 1,42 & 3867 \\
\hline & $5-8 \mathrm{D} 1$ & 6753 & 1,42 & 4756 \\
\hline & $6-8 \mathrm{D}$ & 7570 & 1,42 & 5331 \\
\hline & $7-8 \mathrm{D} 1$ & 6239 & 1,42 & 4394 \\
\hline \multicolumn{4}{|r|}{ Média } & 4906 \\
\hline \multirow{7}{*}{6,5} & $1-8 \mathrm{E}$ & 5526 & 1,22 & 4530 \\
\hline & $2-8 \mathrm{E}$ & 5015 & 1,22 & 4111 \\
\hline & $3-8 \mathrm{E} 1$ & 4956 & 1,22 & 4062 \\
\hline & $4-8 \mathrm{E} 1$ & 4927 & 1,22 & 4039 \\
\hline & $5-8 \mathrm{E}$ & 5170 & 1,22 & 4238 \\
\hline & $6-8 \mathrm{E}$ & 5483 & 1,22 & 4494 \\
\hline & 7-8E1 & 4584 & 1,22 & 3758 \\
\hline
\end{tabular}


Tabela F1: Recuperação Retardada das misturas estudas

\begin{tabular}{|c|c|c|c|c|c|c|c|}
\hline \multicolumn{4}{|c|}{$4,5 \%$} & \multicolumn{4}{|c|}{$5,0 \%$} \\
\hline Ligante & Ensaio & $\begin{array}{c}\text { RR } \\
\text { DNER }\end{array}$ & $\begin{array}{c}\text { RR } \\
\text { NCHRP } \\
\end{array}$ & Ligante & Ensaio & $\begin{array}{c}\text { RR } \\
\text { DNER }\end{array}$ & $\begin{array}{c}\text { RR } \\
\text { NCHRP } \\
\end{array}$ \\
\hline \multirow{8}{*}{$100-0-0$} & $1-1 \mathrm{~A}$ & 0,334 & 0,258 & \multirow{8}{*}{$100-0-0$} & $1-1 \mathrm{~B}$ & 0,291 & 0,241 \\
\hline & $2-1 \mathrm{~A}$ & 0,267 & 0,266 & & $2-1 B$ & 0,220 & 0,236 \\
\hline & $3-1 \mathrm{~A}$ & 0,224 & 0,180 & & $3-1 \mathrm{~B}$ & 0,278 & 0,250 \\
\hline & 4-1A & 0,299 & 0,244 & & $4-1 B$ & 0,345 & 0,246 \\
\hline & $5-1 \mathrm{~A}$ & 0,300 & 0,239 & & $5-1 B$ & 0,299 & 0,235 \\
\hline & $6-1 \mathrm{~A}$ & 0,264 & 0,248 & & $6-1 B$ & 0,314 & 0,247 \\
\hline & $7-1 \mathrm{~A}$ & 0,369 & 0,249 & & $7-1 \mathrm{~B}$ & 0,304 & 0,256 \\
\hline & Média & 0,294 & 0,240 & & Média & 0,293 & 0,244 \\
\hline \multirow{8}{*}{ 93-0-7 } & $1-2 \mathrm{~A}$ & 0,378 & 0,264 & \multirow{8}{*}{ 93-0-7 } & $1-2 \mathrm{~B} 1$ & 0,357 & 0,264 \\
\hline & $2-2 \mathrm{~A}$ & 0,377 & 0,255 & & $2-2 B$ & 0,394 & 0,265 \\
\hline & $3-2 \mathrm{~A}$ & 0,387 & 0,286 & & $3-2 B$ & 0,378 & 0,254 \\
\hline & $4-2 \mathrm{~A}$ & 0,388 & 0,251 & & $4-2 B$ & 0,383 & 0,270 \\
\hline & $5-2 \mathrm{~A}$ & 0,414 & 0,260 & & $5-2 B$ & 0,384 & 0,271 \\
\hline & $6-2 \mathrm{~A}$ & 0,394 & 0,265 & & $6-2 \mathrm{~B} 1$ & 0,408 & 0,275 \\
\hline & $7-2 \mathrm{~A}$ & 0,414 & 0,265 & & $7-2 B$ & 0,403 & 0,268 \\
\hline & Média & 0,393 & 0,264 & & Média & $\mathbf{0 , 3 8 7}$ & $\mathbf{0 , 2 6 7}$ \\
\hline \multirow{8}{*}{$86-0-14$} & $1-3 \mathrm{~A}$ & 0,490 & 0,281 & \multirow{8}{*}{$86-0-14$} & $1-3 \mathrm{~B}$ & 0,481 & 0,292 \\
\hline & $2-3 \mathrm{~A}$ & 0,466 & 0,296 & & $2-3 B$ & 0,495 & 0,294 \\
\hline & $3-3 \mathrm{~A}$ & 0,496 & 0,284 & & $3-3 \mathrm{~B}$ & 0,423 & 0,270 \\
\hline & $4-3 \mathrm{~A}$ & 0,444 & 0,277 & & $4-3 B$ & 0,501 & 0,291 \\
\hline & $5-3 \mathrm{~A}$ & 0,427 & 0,270 & & $5-3 \mathrm{~B}$ & 0,492 & 0,293 \\
\hline & $6-3 \mathrm{~A}$ & 0,466 & 0,285 & & $6-3 \mathrm{~B}$ & 0,477 & 0,300 \\
\hline & $7-3 \mathrm{~A}$ & 0,435 & 0,283 & & $7-3 \mathrm{~B}$ & 0,431 & 0,282 \\
\hline & Média & 0,456 & 0,283 & & Média & 0,470 & 0,288 \\
\hline \multirow{8}{*}{ 91-9-0 } & $1-4 \mathrm{~A}$ & 0,309 & 0,257 & \multirow{8}{*}{ 91-9-0 } & $1-4 \mathrm{~B}$ & 0,297 & 0,251 \\
\hline & $2-4 \mathrm{~A}$ & 0,322 & 0,253 & & $2-4 \mathrm{~B}$ & 0,301 & 0,259 \\
\hline & $3-4 \mathrm{~A}$ & 0,327 & 0,249 & & $3-4 \mathrm{~B} 1$ & 0,325 & 0,252 \\
\hline & 4-4A & 0,338 & 0,260 & & 4-4B1 & 0,332 & 0,261 \\
\hline & $5-4 A$ & 0,317 & 0,245 & & $5-4 B$ & 0,314 & 0,255 \\
\hline & $6-4 \mathrm{~A}$ & 0,336 & 0,254 & & $6-4 B$ & 0,304 & 0,238 \\
\hline & $7-4 \mathrm{~A}$ & 0,338 & 0,258 & & $7-4 \mathrm{~B}$ & 0,288 & 0,259 \\
\hline & Média & 0,327 & 0,254 & & Média & 0,309 & 0,254 \\
\hline
\end{tabular}




\begin{tabular}{|c|c|c|c|}
\hline \multicolumn{4}{|c|}{$4,5 \%$} \\
\hline Ligante & Ensaio & $\begin{array}{c}\text { RR } \\
\text { DNER }\end{array}$ & $\begin{array}{c}\text { RR } \\
\text { NCHRP } \\
\end{array}$ \\
\hline \multirow{8}{*}{ 82-18-0 } & $1-6 \mathrm{~A}$ & 0,331 & 0,250 \\
\hline & $2-6 \mathrm{~A}$ & 0,318 & 0,254 \\
\hline & 3-6A1 & 0,278 & 0,235 \\
\hline & $4-6 \mathrm{~A} 1$ & 0,236 & 0,211 \\
\hline & 5-6A1 & 0,218 & 0,201 \\
\hline & 6-6A1 & 0,203 & 0,172 \\
\hline & 7-6A1 & 0,235 & 0,185 \\
\hline & Média & 0,260 & 0,215 \\
\hline
\end{tabular}

\begin{tabular}{|c|c|c|c|}
\hline \multicolumn{4}{|c|}{$5,0 \%$} \\
\hline $\begin{array}{c}\% \\
\text { Ligante }\end{array}$ & Ensaio & $\begin{array}{c}\text { RR } \\
\text { DNER }\end{array}$ & $\begin{array}{c}\text { RR } \\
\text { NCHRP }\end{array}$ \\
\hline \multirow{8}{*}{ 82-18-0 } & $1-6 \mathrm{~B} 1$ & 0,321 & 0,237 \\
\hline & $2-6 B$ & 0,346 & 0,241 \\
\hline & $3-6 B$ & 0,346 & 0,243 \\
\hline & $4-6 \mathrm{~B} 1$ & 0,332 & 0,244 \\
\hline & $5-6 B$ & 0,323 & 0,250 \\
\hline & $6-6 \mathrm{~B}$ & 0,307 & 0,248 \\
\hline & $7-6 \mathrm{~B} 1$ & 0,292 & 0,241 \\
\hline & Média & 0,324 & 0,243 \\
\hline
\end{tabular}

\begin{tabular}{cc|c|c}
\hline & 1-5A1 & 0,292 & 0,243 \\
\cline { 2 - 4 } 2-5A & 0,342 & 0,245 \\
\cline { 2 - 4 } 77-9-14 & 3-5A & 0,300 & 0,235 \\
\cline { 2 - 4 } 4-5A1 & 0,316 & 0,243 \\
\cline { 2 - 4 } 5-5A1 & 0,325 & 0,238 \\
\hline 6-5A1 & 0,292 & 0,236 \\
\hline 7-5A1 & 0,343 & 0,254 \\
\hline \multicolumn{2}{|c}{ Média } & $\mathbf{0 , 3 1 6}$ & $\mathbf{0 , 2 4 2}$ \\
\hline
\end{tabular}

\begin{tabular}{cl|l|l}
\hline 1-5B1 & 0,347 & 0,267 \\
\cline { 2 - 4 } 2-5B1 & 0,351 & 0,262 \\
\cline { 2 - 4 } 77-9-14 & 3-5B & 0,355 & 0,255 \\
\cline { 2 - 4 } & 5-5B1 & 0,360 & 0,258 \\
\hline & 6-5B 1 & 0,359 & 0,262 \\
\hline 7-5B & 0,370 & 0,257 \\
\hline \multicolumn{2}{|c|}{ Média } & 0,375 & 0,258 \\
\hline
\end{tabular}

\begin{tabular}{cl|l|l}
\hline & 1-7A & 0,306 & 0,241 \\
\cline { 2 - 4 } 2-7A1 & 0,300 & 0,235 \\
\cline { 2 - 4 } 75-18-7 & 3-7A1 & 0,282 & 0,236 \\
\cline { 2 - 4 } 4-7A & 0,333 & 0,250 \\
\cline { 2 - 4 } 5-7A & 0,297 & 0,236 \\
\hline & 6-7A1 & 0,292 & 0,242 \\
\hline 7-7A & 0,345 & 0,253 \\
\hline
\end{tabular}

\begin{tabular}{rl|l|l}
\hline 1-7B & 0,273 & 0,213 \\
\cline { 2 - 4 } 2-7B & 0,275 & 0,238 \\
\cline { 2 - 4 } 75-18-7 & 3-7B & 0,280 & 0,271 \\
\cline { 2 - 4 } & 4-7B & 0,296 & 0,250 \\
\cline { 2 - 4 } 5-7B1 & 0,292 & 0,244 \\
\hline 6-7B & 0,326 & 0,246 \\
\hline 7-7B1 & 0,317 & 0,243 \\
\hline
\end{tabular}

\begin{tabular}{|c|c|c|c|}
\hline \multirow{7}{*}{$\begin{array}{c}\text { 68-18- } \\
14\end{array}$} & 1-8A1 & 0,351 & 0,273 \\
\hline & $2-8 \mathrm{~A}$ & 0,345 & 0,265 \\
\hline & $3-8 \mathrm{~A}$ & 0,366 & 0,266 \\
\hline & 4-8A & 0,345 & 0,280 \\
\hline & 5-8A1 & 0,358 & 0,254 \\
\hline & $6-8 \mathrm{~A}$ & 0,348 & 0,256 \\
\hline & $7-8 \mathrm{~A} 1$ & 0,359 & 0,278 \\
\hline & Média & 0,353 & 0,267 \\
\hline
\end{tabular}

\begin{tabular}{|c|c|c|c|}
\hline \multirow{8}{*}{$\begin{array}{c}\text { 68-18- } \\
14\end{array}$} & $1-8 \mathrm{~B} 1$ & 0,306 & 0,268 \\
\hline & $2-8 \mathrm{~B}$ & 0,338 & 0,282 \\
\hline & $3-8 \mathrm{~B} 1$ & 0,358 & 0,265 \\
\hline & $4-8 \mathrm{~B}$ & 0,330 & 0,285 \\
\hline & $5-8 \mathrm{~B} 1$ & 0,327 & 0,286 \\
\hline & $6-8 \mathrm{~B} 1$ & 0,358 & 0,279 \\
\hline & $7-8 \mathrm{~B} 1$ & 0,361 & 0,272 \\
\hline & Média & 0,340 & 0,277 \\
\hline
\end{tabular}




\begin{tabular}{|c|c|c|c|}
\hline \multicolumn{4}{|c|}{$5,5 \%$} \\
\hline Ligante & Ensaio & $\begin{array}{c}\text { RR } \\
\text { DNER }\end{array}$ & $\begin{array}{c}\text { RR } \\
\text { NCHRP } \\
\end{array}$ \\
\hline \multirow{8}{*}{$100-0-0$} & $1-1 \mathrm{C}$ & 0,287 & 0,237 \\
\hline & $2-1 C$ & 0,300 & 0,235 \\
\hline & $3-1 \mathrm{C}$ & 0,359 & 0,262 \\
\hline & $4-1 \mathrm{C}$ & 0,331 & 0,251 \\
\hline & $5-1 \mathrm{C}$ & 0,362 & 0,262 \\
\hline & $6-1 \mathrm{C}$ & 0,366 & 0,258 \\
\hline & $7-1 \mathrm{C}$ & 0,312 & 0,253 \\
\hline & Média & 0,331 & 0,251 \\
\hline
\end{tabular}

\begin{tabular}{c|l|c|c}
\hline \multicolumn{4}{c}{$\mathbf{6 , 0 \%}$} \\
\hline \multirow{2}{*}{ Ligante } & Ensaio & $\begin{array}{c}\text { RR } \\
\text { DNER }\end{array}$ & $\begin{array}{c}\text { RR } \\
\text { NCHRP }\end{array}$ \\
\hline & 1-1D & 0,332 & 0,247 \\
\cline { 2 - 4 } 2-1D & 0,326 & 0,249 \\
\cline { 2 - 4 } $\mathbf{1 0 0 - 0 - 0}$ & 3-1D1 & 0,329 & 0,250 \\
\cline { 2 - 4 } & $4-1 D$ & 0,352 & 0,266 \\
\cline { 2 - 4 } & 5-1D1 & 0,336 & 0,245 \\
\cline { 2 - 4 } & 6-1D & 0,333 & 0,244 \\
\cline { 2 - 4 } & $7-1 D 1$ & 0,345 & 0,251 \\
\hline \multicolumn{2}{c}{ Média } & $\mathbf{0 , 3 3 6}$ & $\mathbf{0 , 2 5 0}$ \\
\cline { 2 - 4 } & & &
\end{tabular}

\begin{tabular}{cc|c|c}
\hline & $1-2 \mathrm{C}$ & 0,436 & 0,271 \\
\cline { 2 - 4 } 93-0-7 & 2-2 & 0,414 & 0,258 \\
\cline { 2 - 4 } 3-2C & 0,392 & 0,274 \\
\cline { 2 - 4 } & 4-2C & 0,392 & 0,266 \\
\cline { 2 - 4 } 5-2C & 0,474 & 0,282 \\
\cline { 2 - 4 } 6-2C & 0,492 & 0,295 \\
\cline { 2 - 4 } 7-2C & 0,415 & 0,273 \\
\hline
\end{tabular}

\begin{tabular}{cc|c|c}
\hline & $1-2 \mathrm{D}$ & 0,535 & 0,293 \\
\cline { 2 - 4 } 2-2D & 0,424 & 0,256 \\
\cline { 2 - 4 } $\mathbf{9 3 - 0 - 7}$ & 3-2D & 0,433 & 0,254 \\
\cline { 2 - 4 } & 4-2D & 0,511 & 0,283 \\
\cline { 2 - 4 } & 5-2D & 0,487 & 0,288 \\
\hline & 6-2D & 0,429 & 0,280 \\
\hline 7-2D & 0,506 & 0,298 \\
\hline
\end{tabular}

\begin{tabular}{rl|l|l}
\hline & $1-3 C$ & 0,459 & 0,282 \\
\cline { 2 - 4 } 2-3C & 0,544 & 0,297 \\
\cline { 2 - 4 } 86-0-14 3 -3C & 0,509 & 0,286 \\
\cline { 2 - 4 } & 4-3C & 0,467 & 0,261 \\
\cline { 2 - 4 } 5-3C & 0,446 & 0,272 \\
\cline { 2 - 4 } 6-3C & 0,476 & 0,298 \\
\cline { 2 - 4 } 7-3C & 0,491 & 0,283 \\
\hline
\end{tabular}

\begin{tabular}{cc|c|c}
\hline & $1-3 D$ & 0,483 & 0,295 \\
\cline { 2 - 4 } $\mathbf{8 6 - 3 D - 1 4}$ & 0,478 & 0,295 \\
\cline { 2 - 4 } $\mathbf{8 - 3 D}$ & 0,507 & 0,302 \\
\cline { 2 - 4 } & 4-3D & 0,492 & 0,286 \\
\cline { 2 - 4 } 5-3D & 0,483 & 0,283 \\
\cline { 2 - 4 } 6-3D & 0,474 & 0,284 \\
\hline & 7-3D & 0,486 & 0,295 \\
\hline & Média & $\mathbf{0 , 4 8 7}$ & $\mathbf{0 , 2 9 1}$ \\
\hline
\end{tabular}

\begin{tabular}{cl|l|l}
\hline & $1-4 \mathrm{C}$ & 0,290 & 0,255 \\
\cline { 2 - 4 } 91-9-0 1 & 0,277 & 0,253 \\
\cline { 2 - 4 } & 3-4C & 0,316 & 0,254 \\
\cline { 2 - 4 } & 4-4C1 & 0,272 & 0,213 \\
\cline { 2 - 4 } 5-4C1 & 0,305 & 0,253 \\
\hline & 6-4C1 & 0,316 & 0,259 \\
\hline 7-4C1 & 0,318 & 0,246 \\
\hline & Média & $\mathbf{0 , 2 9 9}$ & $\mathbf{0 , 2 4 7}$ \\
\hline
\end{tabular}

\begin{tabular}{cl|l|l}
\hline & 1-4D & 0,316 & 0,257 \\
\cline { 2 - 4 } 2-4D & 0,320 & 0,247 \\
\cline { 2 - 4 } 91-9-0 & 3-4D1 & 0,311 & 0,249 \\
\cline { 2 - 4 } & 4-4D & 0,323 & 0,243 \\
\cline { 2 - 4 } 5-4D & 0,316 & 0,258 \\
\cline { 2 - 4 } & 6-4D & 0,311 & 0,250 \\
\hline & 7-4D & 0,345 & 0,260 \\
\hline
\end{tabular}




\begin{tabular}{|c|c|c|c|}
\hline \multicolumn{4}{|c|}{$5,5 \%$} \\
\hline Ligante & Ensaio & $\begin{array}{c}\text { RR } \\
\text { DNER }\end{array}$ & $\begin{array}{c}\text { RR } \\
\text { NCHRP }\end{array}$ \\
\hline \multirow{8}{*}{$82-18-0$} & $1-6 \mathrm{C} 1$ & 0,207 & 0,201 \\
\hline & $2-6 C$ & 0,213 & 0,203 \\
\hline & $3-6 C$ & 0,230 & 0,208 \\
\hline & $4-6 \mathrm{C} 1$ & 0,277 & 0,217 \\
\hline & $5-6 \mathrm{C} 1$ & 0,251 & 0,180 \\
\hline & $6-6 \mathrm{C} 1$ & 0,211 & 0,195 \\
\hline & $7-6 C$ & 0,318 & 0,230 \\
\hline & Média & 0,244 & 0,205 \\
\hline
\end{tabular}

\begin{tabular}{|c|c|c|c|}
\hline \multicolumn{4}{|c|}{$6,0 \%$} \\
\hline Ligante & Ensaio & $\begin{array}{c}\text { RR } \\
\text { DNER }\end{array}$ & $\begin{array}{c}\text { RR } \\
\text { NCHRP }\end{array}$ \\
\hline \multirow{8}{*}{ 82-18-0 } & $1-6 \mathrm{D} 1$ & 0,232 & 0,170 \\
\hline & $2-6 D$ & 0,262 & 0,223 \\
\hline & $3-6 \mathrm{D} 1$ & 0,255 & 0,222 \\
\hline & $4-6 \mathrm{D} 1$ & 0,292 & 0,224 \\
\hline & $5-6 D$ & 0,283 & 0,239 \\
\hline & $6-6 \mathrm{D}$ & 0,302 & 0,233 \\
\hline & $7-6 \mathrm{D}$ & 0,312 & 0,249 \\
\hline & Média & 0,277 & 0,223 \\
\hline
\end{tabular}

\begin{tabular}{cl|l|l}
\hline & $1-5 \mathrm{C}$ & 0,396 & 0,265 \\
\cline { 2 - 4 } 2-5C1 & 0,369 & 0,269 \\
\cline { 2 - 4 } 77-9-14 & 3-5C & 0,387 & 0,273 \\
\cline { 2 - 4 } 4-5C1 & 0,365 & 0,274 \\
\cline { 2 - 4 } 5-5C1 & 0,367 & 0,279 \\
\hline 6-5C1 & 0,370 & 0,271 \\
\hline 7-5C & 0,390 & 0,266 \\
\hline \multicolumn{2}{c}{ Média } & $\mathbf{0 , 3 7 8}$ & $\mathbf{0 , 2 7 1}$ \\
\hline
\end{tabular}

\begin{tabular}{|c|c|c|c|}
\hline \multirow{8}{*}{$77-9-14$} & $1-5 \mathrm{D} 1$ & 0,389 & 0,259 \\
\hline & $2-5 \mathrm{D} 1$ & 0,393 & 0,261 \\
\hline & $3-5 \mathrm{D} 1$ & 0,375 & 0,259 \\
\hline & 4-5D & 0,413 & 0,274 \\
\hline & 5-5D1 & 0,401 & 0,263 \\
\hline & 6-5D1 & 0,399 & 0,266 \\
\hline & $7-5 \mathrm{D} 1$ & 0,409 & 0,277 \\
\hline & Média & 0,397 & 0,265 \\
\hline \multirow{8}{*}{$75-18-7$} & $1-7 \mathrm{D}$ & 0,275 & 0,236 \\
\hline & $2-7 \mathrm{D}$ & 0,284 & 0,236 \\
\hline & $3-7 \mathrm{D}$ & 0,278 & 0,241 \\
\hline & 4-7D & 0,296 & 0,244 \\
\hline & $5-7 \mathrm{D}$ & 0,316 & 0,258 \\
\hline & 6-7D1 & 0,309 & 0,255 \\
\hline & $7-7 \mathrm{D}$ & 0,344 & 0,252 \\
\hline & Média & 0,300 & 0,246 \\
\hline
\end{tabular}

\begin{tabular}{cc|c|c}
\hline & 1-7C1 & 0,308 & 0,262 \\
\cline { 2 - 4 } 2-7C1 & 0,340 & 0,267 \\
\cline { 2 - 4 } 75-18-7 & 3-7C & 0,316 & 0,265 \\
\cline { 2 - 4 } 4-7C1 & 0,304 & 0,258 \\
\cline { 2 - 4 } 5-7C & 0,344 & 0,272 \\
\hline 6-7C & 0,316 & 0,257 \\
\hline 7-7C1 & 0,341 & 0,261 \\
\hline Média & $\mathbf{0 , 3 2 4}$ & $\mathbf{0 , 2 6 3}$ \\
\hline
\end{tabular}

\begin{tabular}{cc|c|c}
\hline & $1-8 \mathrm{D}$ & 0,347 & 0,273 \\
\cline { 2 - 4 } $\begin{array}{c}\mathbf{6 8 - 1 8} \\
\mathbf{1 4}\end{array}$ & 2-8D & 0,321 & 0,264 \\
\cline { 2 - 4 } & 3-8D & 0,338 & 0,256 \\
\cline { 2 - 4 } & 4-8D1 & 0,333 & 0,263 \\
\hline & 5-8D & 0,331 & 0,269 \\
\hline & 6-8D1 & 0,334 & 0,276 \\
\hline & 7-8D1 & 0,347 & 0,269 \\
\hline & Média & $\mathbf{0 , 3 3 6}$ & $\mathbf{0 , 2 6 7}$ \\
\hline
\end{tabular}




\begin{tabular}{|c|c|c|c|}
\hline \multicolumn{4}{|c|}{$6,5 \%$} \\
\hline Ligante & Ensaio & $\begin{array}{c}\text { RR } \\
\text { DNER }\end{array}$ & $\begin{array}{c}\text { RR } \\
\text { NCHRP }\end{array}$ \\
\hline \multirow{8}{*}{$100-0-0$} & $1-1 \mathrm{E}$ & 0,366 & 0,282 \\
\hline & $2-1 \mathrm{E} 1$ & 0,357 & 0,277 \\
\hline & 3-1E1 & 0,369 & 0,257 \\
\hline & 4-1E & 0,364 & 0,265 \\
\hline & $5-1 \mathrm{E}$ & 0,373 & 0,264 \\
\hline & $6-1 \mathrm{E}$ & 0,377 & 0,255 \\
\hline & $7-1 \mathrm{E} 1$ & 0,379 & 0,266 \\
\hline & Média & 0,369 & 0,267 \\
\hline \multirow{8}{*}{$93-0-7$} & $1-2 \mathrm{E}$ & 0,436 & 0,279 \\
\hline & $2-2 \mathrm{E}$ & 0,419 & 0,272 \\
\hline & $3-2 \mathrm{E}$ & 0,441 & 0,270 \\
\hline & $4-2 \mathrm{E}$ & 0,494 & 0,297 \\
\hline & $5-2 \mathrm{E}$ & 0,429 & 0,283 \\
\hline & $6-2 \mathrm{E}$ & 0,501 & 0,296 \\
\hline & $7-2 \mathrm{E}$ & 0,517 & 0,288 \\
\hline & Média & 0,462 & 0,284 \\
\hline \multirow{8}{*}{ 86-0-14 } & $1-3 E$ & 0,458 & 0,272 \\
\hline & $2-3 E$ & 0,478 & 0,287 \\
\hline & $3-3 E$ & 0,480 & 0,283 \\
\hline & 4-3E & 0,526 & 0,292 \\
\hline & $5-3 E$ & 0,504 & 0,283 \\
\hline & $6-3 E$ & 0,463 & 0,278 \\
\hline & $7-3 \mathrm{E}$ & 0,475 & 0,294 \\
\hline & Média & 0,488 & 0,286 \\
\hline \multirow{8}{*}{ 91-9-0 } & $1-4 \mathrm{E} 1$ & 0,296 & 0,259 \\
\hline & $2-4 \mathrm{E} 1$ & 0,320 & 0,250 \\
\hline & $3-4 \mathrm{E} 1$ & 0,297 & 0,229 \\
\hline & 4-4E1 & 0,314 & 0,239 \\
\hline & $5-4 \mathrm{E} 1$ & 0,316 & 0,245 \\
\hline & $6-4 \mathrm{E}$ & 0,287 & 0,251 \\
\hline & $7-4 \mathrm{E} 1$ & 0,321 & 0,255 \\
\hline & Média & $\mathbf{0 , 3 0 7}$ & 0,247 \\
\hline
\end{tabular}

\begin{tabular}{|c|c|c|c|}
\hline \multicolumn{4}{|c|}{$6,5 \%$} \\
\hline Ligante & Ensaio & $\begin{array}{c}\text { RR } \\
\text { DNER }\end{array}$ & $\begin{array}{c}\text { RR } \\
\text { NCHRP }\end{array}$ \\
\hline \multirow{8}{*}{ 82-18-0 } & $1-6 \mathrm{E} 1$ & 0,339 & 0,253 \\
\hline & $2-6 \mathrm{E} 1$ & 0,330 & 0,251 \\
\hline & $3-6 \mathrm{E}$ & 0,326 & 0,243 \\
\hline & $4-6 \mathrm{E} 1$ & 0,299 & 0,239 \\
\hline & $5-6 \mathrm{E}$ & 0,324 & 0,260 \\
\hline & $6-6 \mathrm{E}$ & 0,312 & 0,250 \\
\hline & $7-6 \mathrm{E} 1$ & 0,335 & 0,256 \\
\hline & Média & 0,324 & 0,250 \\
\hline \multirow{8}{*}{$77-9-14$} & $1-5 \mathrm{E} 1$ & 0,407 & 0,268 \\
\hline & $2-5 \mathrm{E} 1$ & 0,392 & 0,266 \\
\hline & $3-5 \mathrm{E} 1$ & 0,385 & 0,259 \\
\hline & $4-5 E$ & 0,411 & 0,273 \\
\hline & $5-5 \mathrm{E}$ & 0,436 & 0,289 \\
\hline & $6-5 \mathrm{E} 1$ & 0,411 & 0,275 \\
\hline & $7-5 E$ & 0,407 & 0,274 \\
\hline & Média & 0,407 & 0,272 \\
\hline \multirow{8}{*}{$75-18-7$} & $1-7 \mathrm{E}$ & 0,339 & 0,263 \\
\hline & $2-7 \mathrm{E} 1$ & 0,350 & 0,263 \\
\hline & $3-7 \mathrm{E}$ & 0,322 & 0,270 \\
\hline & $4-7 \mathrm{E}$ & 0,361 & 0,271 \\
\hline & $5-7 \mathrm{E}$ & 0,366 & 0,260 \\
\hline & 6-7E1 & 0,355 & 0,267 \\
\hline & $7-7 \mathrm{E}$ & 0,346 & 0,271 \\
\hline & Média & 0,348 & 0,266 \\
\hline \multirow{8}{*}{ 68-18-14 } & $1-8 \mathrm{E}$ & 0,366 & 0,266 \\
\hline & $2-8 E$ & 0,381 & 0,276 \\
\hline & $3-8 \mathrm{E}$ & 0,357 & 0,277 \\
\hline & $\begin{array}{l}4-8 \mathrm{E} 1 \\
\end{array}$ & 0,362 & 0,278 \\
\hline & $5-8 \mathrm{E}$ & 0,378 & 0,276 \\
\hline & $6-8 \mathrm{E}$ & 0,397 & 0,297 \\
\hline & $7-8 \mathrm{E} 1$ & 0,340 & 0,281 \\
\hline & Média & 0,369 & 0,278 \\
\hline
\end{tabular}


Tabela G1: Módulo de Resiliência condicionados das misturas estudadas

LIGANTE 1 (100-0-0)

\begin{tabular}{|c|c|c|c|}
\hline $\begin{array}{l}\text { Teor } \\
(\%)\end{array}$ & $\begin{array}{c}\text { Corpo-de- } \\
\text { prova }\end{array}$ & $\begin{array}{c}\text { MR }_{\text {I }} \\
\text { NCHRP } \\
\text { (MPa) }\end{array}$ & $\begin{array}{c}\mathbf{M R}_{\mathrm{T}}- \\
\text { NCHRP } \\
\text { (MPa) }\end{array}$ \\
\hline \multirow{3}{*}{4,5} & $5-1 \mathrm{~A}$ & 14895 & 11172 \\
\hline & $6-1 \mathrm{~A}$ & 18072 & 13415 \\
\hline & $7-1 \mathrm{~A}$ & 15238 & 10992 \\
\hline \multirow{3}{*}{5,0} & $1-1 \mathrm{~B}$ & 19433 & 14412 \\
\hline & $3-1 \mathrm{~B}$ & 18671 & 13835 \\
\hline & 4-1B & 16902 & 12370 \\
\hline \multirow{3}{*}{5,5} & $5-1 \mathrm{C}$ & 33465 & 19317 \\
\hline & $6-1 \mathrm{C}$ & 23564 & 17647 \\
\hline & $7-1 \mathrm{C}$ & 25721 & 19803 \\
\hline \multirow{3}{*}{6,0} & $3-1 \mathrm{D}$ & 26319 & 18821 \\
\hline & $4-1 \mathrm{D}$ & 21474 & 15882 \\
\hline & 6-1D & 22013 & 15724 \\
\hline \multirow{3}{*}{6,5} & $4-1 \mathrm{E}$ & 16941 & 12511 \\
\hline & $5-1 \mathrm{E}$ & 19821 & 14539 \\
\hline & $6-1 \mathrm{E}$ & 15263 & 11241 \\
\hline \multicolumn{4}{|c|}{ LIGANTE 2 (93-0-7) } \\
\hline $\begin{array}{l}\text { Teor } \\
(\%)\end{array}$ & $\begin{array}{c}\text { Corpo-de- } \\
\text { prova }\end{array}$ & $\begin{array}{c}\text { MR }_{\mathbf{I}}^{-} \\
\text {NCHRP } \\
\text { (MPa) }\end{array}$ & $\begin{array}{c}\mathbf{M R}_{\mathrm{T}}- \\
\text { NCHRP } \\
\text { (MPa) }\end{array}$ \\
\hline \multirow{3}{*}{4,5} & $1-2 \mathrm{~A}$ & 13201 & 9696 \\
\hline & $3-2 \mathrm{~A}$ & 12327 & 8934 \\
\hline & $4-2 \mathrm{~A}$ & 13434 & 9698 \\
\hline \multirow{3}{*}{5,0} & $3-2 \mathrm{~B}$ & 16507 & 12044 \\
\hline & $4-2 \mathrm{~B}$ & 17844 & 13221 \\
\hline & $6-2 \mathrm{~B}$ & 18412 & 13632 \\
\hline \multirow{3}{*}{5,5} & $1-2 \mathrm{C}$ & $*$ & $*$ \\
\hline & $3-2 \mathrm{C}$ & $*$ & $*$ \\
\hline & $7-2 \mathrm{C}$ & $*$ & $*$ \\
\hline \multirow{3}{*}{6,0} & $2-2 \mathrm{D}$ & $*$ & * \\
\hline & $5-2 \mathrm{D}$ & $*$ & $*$ \\
\hline & 6-2D & $*$ & $*$ \\
\hline \multirow{3}{*}{6,5} & $4-2 \mathrm{E}$ & $*$ & $*$ \\
\hline & $5-2 \mathrm{E}$ & $*$ & $*$ \\
\hline & $7-2 \mathrm{E}$ & $*$ & * \\
\hline
\end{tabular}

LIGANTE 5(77-9-14)

\begin{tabular}{|c|c|c|c|}
\hline $\begin{array}{l}\text { Teor } \\
(\%)\end{array}$ & $\begin{array}{c}\text { Corpo-de- } \\
\text { prova }\end{array}$ & $\begin{array}{c}\text { MR }_{\mathbf{I}} \\
\text { NCHRP } \\
\text { (MPa) }\end{array}$ & $\begin{array}{c}\mathbf{M R}_{\mathrm{T}}- \\
\text { NCHRP } \\
\text { (MPa) }\end{array}$ \\
\hline \multirow{3}{*}{4,5} & $2-5 \mathrm{~A}$ & 12634 & 9263 \\
\hline & $4-5 \mathrm{~A}$ & 10140 & 7443 \\
\hline & $5-5 \mathrm{~A}$ & 9493 & 6923 \\
\hline \multirow{3}{*}{5,0} & $1-5 B$ & 7183 & 5132 \\
\hline & $3-5 B$ & 7556 & 5450 \\
\hline & $7-5 B$ & 7618 & 5440 \\
\hline \multirow{3}{*}{5,5} & $4-5 \mathrm{C}$ & $*$ & $*$ \\
\hline & $5-5 \mathrm{C}$ & 6885 & 4950 \\
\hline & $6-5 C$ & 7656 & 5457 \\
\hline \multirow{3}{*}{6,0} & $3-5 \mathrm{D}$ & $*$ & $*$ \\
\hline & $5-5 \mathrm{D}$ & $*$ & $*$ \\
\hline & $7-5 \mathrm{D}$ & $*$ & $*$ \\
\hline \multirow{3}{*}{6,5} & $3-5 \mathrm{E}$ & $*$ & $*$ \\
\hline & $4-5 \mathrm{E}$ & $*$ & $*$ \\
\hline & $5-5 \mathrm{E}$ & 6192 & 4367 \\
\hline \multicolumn{4}{|c|}{$6(82-18-0)$} \\
\hline
\end{tabular}

\begin{tabular}{|c|c|c|c|}
\hline Teor (\%) & $\begin{array}{c}\text { Corpo- } \\
\text { de- } \\
\text { prova }\end{array}$ & $\begin{array}{c}\text { MR }_{\mathbf{I}}^{-} \\
\text {NCHRP } \\
\text { (MPa) }\end{array}$ & $\begin{array}{c}\mathrm{MR}_{\mathrm{T}}- \\
\text { NCHRP } \\
\text { (MPa) } \\
\text { (cond) }\end{array}$ \\
\hline \multirow{3}{*}{4,5} & $5-6 \mathrm{~A}$ & 10198 & 7752 \\
\hline & $6-6 \mathrm{~A}$ & 11825 & 9109 \\
\hline & $7-6 \mathrm{~A}$ & 12249 & 9250 \\
\hline \multirow{3}{*}{5,0} & $1-6 \mathrm{~B}$ & 9294 & 6850 \\
\hline & $3-6 B$ & 10444 & 7678 \\
\hline & $4-6 \mathrm{~B}$ & 8711 & 6329 \\
\hline \multirow{3}{*}{5,5} & $1-6 \mathrm{C}$ & 16134 & 12266 \\
\hline & $2-6 \mathrm{C}$ & $*$ & $*$ \\
\hline & $5-6 \mathrm{C}$ & $*$ & $*$ \\
\hline \multirow{3}{*}{6,0} & $2-6 \mathrm{D}$ & $*$ & $*$ \\
\hline & $5-6 \mathrm{D}$ & $*$ & $*$ \\
\hline & $6-6 \mathrm{D}$ & $*$ & $*$ \\
\hline \multirow{3}{*}{6,5} & $1-6 \mathrm{E}$ & $*$ & $*$ \\
\hline & $6-6 \mathrm{E}$ & $*$ & $*$ \\
\hline & $7-6 \mathrm{E}$ & $*$ & $*$ \\
\hline
\end{tabular}


LIGANTE 3 (86-0-14)

\begin{tabular}{|c|c|c|c|}
\hline $\begin{array}{l}\text { Teor } \\
(\%)\end{array}$ & $\begin{array}{c}\text { Corpo-de- } \\
\text { prova }\end{array}$ & $\begin{array}{c}\text { MR }_{\mathbf{I}}^{-} \\
\text {NCHRP } \\
\text { (MPa) }\end{array}$ & $\begin{array}{c}\mathrm{MR}_{\mathrm{T}}- \\
\text { NCHRP } \\
\text { (MPa) } \\
\text { (cond) }\end{array}$ \\
\hline \multirow{3}{*}{4,5} & $1-3 A$ & 5191 & 3677 \\
\hline & $3-3 \mathrm{~A}$ & 6607 & 4660 \\
\hline & $7-3 \mathrm{~A}$ & 7120 & 5094 \\
\hline \multirow{3}{*}{5,0} & $2-3 B$ & 10120 & 7252 \\
\hline & 4-3B & 10252 & 7347 \\
\hline & $5-3 B$ & 10314 & 7430 \\
\hline \multirow{3}{*}{5,5} & $2-3 C$ & $*$ & $*$ \\
\hline & $5-3 C$ & $*$ & $*$ \\
\hline & $6-3 \mathrm{C}$ & $*$ & $*$ \\
\hline \multirow{3}{*}{6,0} & $2-3 \mathrm{D}$ & $*$ & $*$ \\
\hline & 4-3D & $*$ & $*$ \\
\hline & $7-3 \mathrm{D}$ & $*$ & $*$ \\
\hline \multirow{3}{*}{6,5} & $2-3 \mathrm{E}$ & $*$ & $*$ \\
\hline & $4-3 \mathrm{E}$ & $*$ & $*$ \\
\hline & $6-3 \mathrm{E}$ & $*$ & $*$ \\
\hline \multicolumn{4}{|c|}{ LIGANTE 4(91-9-0) } \\
\hline $\begin{array}{l}\text { Teor } \\
(\%)\end{array}$ & $\begin{array}{l}\text { Corpo-de- } \\
\text { prova }\end{array}$ & $\begin{array}{c}\text { MR }_{\mathbf{I}}^{-} \\
\text {NCHRP } \\
\text { (MPa) }\end{array}$ & $\begin{array}{c}\mathrm{MR}_{\mathrm{T}}- \\
\mathrm{NCHRP} \\
\text { (MPa) } \\
\text { (cond) }\end{array}$ \\
\hline \multirow{3}{*}{4,5} & $2-4 \mathrm{~A}$ & 9062 & 6605 \\
\hline & $3-4 \mathrm{~A}$ & 9757 & 6996 \\
\hline & $7-4 \mathrm{~A}$ & 8310 & 6024 \\
\hline \multirow{3}{*}{5,0} & $2-4 B$ & 13077 & 9665 \\
\hline & $3-4 \mathrm{~B}$ & 12521 & 9286 \\
\hline & 5-4B & 16673 & 12276 \\
\hline \multirow{3}{*}{5,5} & $2-4 C$ & 12872 & 9566 \\
\hline & $3-4 \mathrm{C}$ & 13981 & 10405 \\
\hline & $6-4 \mathrm{C}$ & 17554 & 12924 \\
\hline \multirow{3}{*}{6,0} & $2-4 \mathrm{D}$ & $*$ & $*$ \\
\hline & $3-4 \mathrm{D}$ & $*$ & $*$ \\
\hline & $4-4 \mathrm{D}$ & $*$ & $*$ \\
\hline \multirow{3}{*}{6,5} & $2-4 \mathrm{E}$ & $*$ & $*$ \\
\hline & $3-4 \mathrm{E}$ & 12477 & 9233 \\
\hline & $6-4 \mathrm{E}$ & 11163 & 8120 \\
\hline
\end{tabular}

LIGANTE 7(75-18-7)

\begin{tabular}{|c|c|c|c|}
\hline Teor (\%) & $\begin{array}{c}\text { Corpo- } \\
\text { de- } \\
\text { prova }\end{array}$ & $\begin{array}{c}\text { MR }_{\mathbf{I}}^{-} \\
\text {NCHRP } \\
\text { (MPa) }\end{array}$ & $\begin{array}{c}\mathrm{MR}_{\mathrm{T}}- \\
\text { NCHRP } \\
\text { (MPa) } \\
\text { (cond) }\end{array}$ \\
\hline \multirow{3}{*}{4,5} & $2-7 \mathrm{~A}$ & 8264 & 6145 \\
\hline & $3-7 \mathrm{~A}$ & 9406 & 7042 \\
\hline & $5-7 \mathrm{~A}$ & 8906 & 6536 \\
\hline \multirow{3}{*}{5,0} & $5-7 \mathrm{~B}$ & $*$ & $*$ \\
\hline & $6-7 \mathrm{~B}$ & 8183 & 6076 \\
\hline & $7-7 \mathrm{~B}$ & 8973 & 6580 \\
\hline \multirow{3}{*}{5,5} & $1-7 \mathrm{C}$ & $*$ & $*$ \\
\hline & $3-7 \mathrm{C}$ & 6787 & 4872 \\
\hline & $7-7 \mathrm{C}$ & 6964 & 5024 \\
\hline \multirow{3}{*}{6,0} & $1-7 \mathrm{D}$ & $*$ & $*$ \\
\hline & $3-7 D$ & $*$ & * \\
\hline & 4-7D & $*$ & $*$ \\
\hline \multirow{3}{*}{6,5} & $2-7 \mathrm{E}$ & $*$ & $*$ \\
\hline & $4-7 \mathrm{E}$ & $*$ & $*$ \\
\hline & $7-7 \mathrm{E}$ & $*$ & $*$ \\
\hline
\end{tabular}

\section{LIGANTE 8(68-18-14)}

\begin{tabular}{|c|c|c|c|}
\hline Teor (\%) & $\begin{array}{c}\text { Corpo- } \\
\text { de- } \\
\text { prova }\end{array}$ & $\begin{array}{c}\text { MR }_{\mathbf{I}}^{-} \\
\text {NCHRP } \\
\text { (MPa) }\end{array}$ & $\begin{array}{c}\mathrm{MR}_{\mathrm{T}}- \\
\mathrm{NCHRP} \\
\text { (MPa) } \\
\text { (cond) }\end{array}$ \\
\hline \multirow{3}{*}{4,5} & 4-8A & 2482 & 1792 \\
\hline & $5-8 \mathrm{~A}$ & 4174 & 3020 \\
\hline & $6-8 \mathrm{~A}$ & 4356 & 3138 \\
\hline \multirow{3}{*}{5,0} & $4-8 \mathrm{~B}$ & 2991 & 2154 \\
\hline & $6-8 \mathrm{~B}$ & 3690 & 2726 \\
\hline & $7-8 B$ & 3340 & 2411 \\
\hline \multirow{3}{*}{5,5} & $1-8 \mathrm{C}$ & 6279 & 4559 \\
\hline & $3-8 \mathrm{C}$ & 6601 & 4709 \\
\hline & $4-8 \mathrm{C}$ & 5449 & 4013 \\
\hline \multirow{3}{*}{6,0} & $2-8 \mathrm{D}$ & 6971 & 4982 \\
\hline & $5-8 \mathrm{D}$ & 5562 & 4027 \\
\hline & $7-8 \mathrm{D}$ & 5849 & 4193 \\
\hline \multirow{3}{*}{6,5} & $2-8 \mathrm{E}$ & 5814 & 4187 \\
\hline & $3-8 \mathrm{E}$ & 5622 & 4055 \\
\hline & $4-8 \mathrm{E}$ & 6483 & 4656 \\
\hline
\end{tabular}


Tabela G2: Relação dos módulos de resiliência das misturas estudadas

LIGANTE 1 (100-0-0)

\begin{tabular}{|c|c|c|c|}
\hline Teor (\%) & Corpo-de-prova & $\begin{array}{c}\mathrm{MR}_{\mathrm{T}}-\mathrm{NCHRP} \\
(\mathrm{MPa})\end{array}$ & $\begin{array}{c}\mathrm{MR}_{\mathrm{T}}-\underset{\text { (cond) }}{\mathrm{NCHRP}} \\
\text { (MPa) }\end{array}$ \\
\hline \multirow{3}{*}{4,5} & $5-1 \mathrm{~A}$ & 16675 & 11172 \\
\hline & $6-1 \mathrm{~A}$ & 17178 & 13415 \\
\hline & $7-1 \mathrm{~A}$ & 16806 & 10992 \\
\hline \multirow{3}{*}{5,0} & $1-1 \mathrm{~B}$ & 18096 & 14412 \\
\hline & $3-1 \mathrm{~B}$ & 20191 & 13835 \\
\hline & 4-1B & 17570 & 12370 \\
\hline \multirow{3}{*}{5,5} & $5-1 C$ & 15778 & 19317 \\
\hline & $6-1 \mathrm{C}$ & 16384 & 17647 \\
\hline & $7-1 \mathrm{C}$ & 17549 & 19803 \\
\hline \multirow{3}{*}{6,0} & $3-1 D$ & 17231 & 18821 \\
\hline & 4-1D & 15931 & 15882 \\
\hline & $6-1 \mathrm{D}$ & 16412 & 15724 \\
\hline \multirow{3}{*}{6,5} & $4-1 E$ & 13682 & 12511 \\
\hline & $5-1 E$ & 13719 & 14539 \\
\hline & $6-1 \mathrm{E}$ & 12121 & 11241 \\
\hline \multicolumn{4}{|c|}{ LIGANTE 2 (93-0-7) } \\
\hline Teor (\%) & Corpo-de-prova & $\begin{array}{c}\mathrm{MR}_{\mathrm{T}}-\mathrm{NCHRP} \\
\text { (MPa) }\end{array}$ & $\underset{\text { (cond) }}{\mathrm{MR}_{\mathrm{T}}-\underset{\mathrm{NCHRP}}{\mathrm{N}}}$ \\
\hline \multirow{3}{*}{4,5} & $1-2 \mathrm{~A}$ & 12466 & 9696 \\
\hline & $3-2 \mathrm{~A}$ & 12015 & 8934 \\
\hline & $4-2 \mathrm{~A}$ & 12537 & 9698 \\
\hline \multirow{3}{*}{5,0} & $3-2 B$ & 13092 & 12044 \\
\hline & $4-2 B$ & 13014 & 13221 \\
\hline & $6-2 B$ & 11946 & 13632 \\
\hline \multirow{3}{*}{5,5} & $1-2 \mathrm{C}$ & $*$ & $*$ \\
\hline & $3-2 \mathrm{C}$ & $*$ & $*$ \\
\hline & $7-2 \mathrm{C}$ & $*$ & $*$ \\
\hline \multirow{3}{*}{6,0} & $2-2 \mathrm{D}$ & $*$ & $*$ \\
\hline & $5-2 \mathrm{D}$ & $*$ & $*$ \\
\hline & $6-2 \mathrm{D}$ & $*$ & $*$ \\
\hline \multirow{3}{*}{6,5} & $4-2 E$ & $*$ & $*$ \\
\hline & $5-2 \mathrm{E}$ & $*$ & $*$ \\
\hline & $7-2 \mathrm{E}$ & $*$ & $*$ \\
\hline
\end{tabular}

LIGANTE 3 (86-0-14)

\begin{tabular}{cccc}
\hline \multirow{2}{*}{ Teor (\%) } & Corpo-de-prova & $\begin{array}{c}\mathbf{M R}_{\mathbf{T}}-\mathbf{N C H R P} \\
\text { (MPa) }\end{array}$ & $\begin{array}{c}\mathbf{M R}_{\mathbf{T}}-\mathbf{N C H R P ( M P a )} \\
\text { (cond) }\end{array}$ \\
\hline \multirow{3}{*}{4,5} & $1-3 \mathrm{~A}$ & 7668 & 3677 \\
\cline { 2 - 4 } & $3-3 \mathrm{~A}$ & 6950 & 4660 \\
\cline { 2 - 4 } & $7-3 \mathrm{~A}$ & 6664 & 5094 \\
\hline
\end{tabular}




\begin{tabular}{|c|c|c|c|}
\hline Teor (\%) & Corpo-de-prova & $\begin{array}{c}\mathrm{MR}_{\mathrm{T}}-\mathrm{NCHRP} \\
\text { (MPa) }\end{array}$ & $\mathrm{MR}_{\mathrm{T}}-\underset{\text { (cond) }}{\operatorname{NCHRP}(\mathrm{MPa})}$ \\
\hline \multirow{3}{*}{5,0} & $2-3 B$ & 7519 & 7252 \\
\hline & $4-3 \mathrm{~B}$ & 6886 & 7347 \\
\hline & $5-3 B$ & 7388 & 7430 \\
\hline \multirow{3}{*}{5,5} & $2-3 \mathrm{C}$ & $*$ & $*$ \\
\hline & $5-3 \mathrm{C}$ & $*$ & $*$ \\
\hline & $6-3 C$ & $*$ & $*$ \\
\hline \multirow{3}{*}{6,0} & $2-3 \mathrm{D}$ & $*$ & $*$ \\
\hline & 4-3D & $*$ & $*$ \\
\hline & $7-3 \mathrm{D}$ & $*$ & $*$ \\
\hline \multirow{3}{*}{6,5} & $2-3 \mathrm{E}$ & $*$ & $*$ \\
\hline & $4-3 \mathrm{E}$ & $*$ & $*$ \\
\hline & $6-3 \mathrm{E}$ & $*$ & $*$ \\
\hline \multicolumn{4}{|c|}{ LIGANTE 4(91-9-0) } \\
\hline Teor (\%) & Corpo-de-prova & $\begin{array}{c}\mathrm{MR}_{\mathrm{T}}-\mathrm{NCHRP} \\
(\mathrm{MPa})\end{array}$ & $\begin{array}{c}\mathrm{MR}_{\mathrm{T}}-\mathrm{NCHRP}^{\mathrm{NCHPa}} \text { (cond) } \\
\end{array}$ \\
\hline \multirow{3}{*}{4,5} & $2-4 \mathrm{~A}$ & 13238 & 6605 \\
\hline & $3-4 \mathrm{~A}$ & 11996 & 6996 \\
\hline & $7-4 \mathrm{~A}$ & 11540 & 6024 \\
\hline \multirow{3}{*}{5,0} & $2-4 B$ & 16538 & 9665 \\
\hline & $3-4 B$ & 16484 & 9286 \\
\hline & $5-4 B$ & 16650 & 12276 \\
\hline \multirow{3}{*}{5,5} & $2-4 \mathrm{C}$ & 15964 & 9566 \\
\hline & $3-4 \mathrm{C}$ & 14131 & 10405 \\
\hline & $6-4 \mathrm{C}$ & 15097 & 12924 \\
\hline \multirow{3}{*}{6,0} & $2-4 \mathrm{D}$ & $*$ & $*$ \\
\hline & $3-4 \mathrm{D}$ & $*$ & $*$ \\
\hline & $4-4 \mathrm{D}$ & $*$ & $*$ \\
\hline \multirow{3}{*}{6,5} & $2-4 \mathrm{E}$ & $*$ & $*$ \\
\hline & $3-4 \mathrm{E}$ & 12869 & 9233 \\
\hline & $6-4 \mathrm{E}$ & 13139 & 8120 \\
\hline \multicolumn{4}{|c|}{ LIGANTE 5(77-9-14) } \\
\hline
\end{tabular}

\begin{tabular}{cccc}
\hline \multirow{2}{*}{ Teor (\%) } & Corpo-de-prova & $\begin{array}{c}\mathbf{M R}_{\mathbf{T}}-\mathbf{N C H R P} \\
\text { (MPa) }\end{array}$ & $\begin{array}{c}\mathbf{M R}_{\mathbf{T}}-\mathbf{N C H R P ( M P a )} \\
\text { (cond) }\end{array}$ \\
\hline \multirow{3}{*}{4,5} & $2-5 \mathrm{~A}$ & 10829 & 9263 \\
\cline { 2 - 4 } & $4-5 \mathrm{~A}$ & 12242 & 7443 \\
\cline { 2 - 4 } & $5-5 \mathrm{~A}$ & 11862 & 6923 \\
\cline { 2 - 4 } 5,0 & $1-5 \mathrm{~B}$ & 10433 & 5132 \\
\cline { 2 - 4 } & $3-5 \mathrm{~B}$ & 10435 & 5450 \\
\hline \multirow{2}{*}{5,5} & $7-5 \mathrm{~B}$ & 10275 & 5440 \\
\cline { 2 - 4 } & $4-5 \mathrm{C}$ & $*$ & 4950 \\
\cline { 2 - 4 } & $5-5 \mathrm{C}$ & 8966 & 5457 \\
\hline
\end{tabular}




\begin{tabular}{|c|c|c|c|}
\hline Teor (\%) & Corpo-de-prova & $\begin{array}{c}\mathbf{M R}_{\mathrm{T}}-\mathbf{N C H R P} \\
\text { (MPa) }\end{array}$ & $\begin{array}{c}\mathrm{MR}_{\mathrm{T}}-\underset{\text { (cond) }}{\mathrm{NCHRP}} \\
\text { (MPa) }\end{array}$ \\
\hline \multirow{3}{*}{6,0} & $3-5 \mathrm{D}$ & $*$ & $*$ \\
\hline & $5-5 \mathrm{D}$ & $*$ & $*$ \\
\hline & $7-5 \mathrm{D}$ & $*$ & $*$ \\
\hline \multirow{3}{*}{6,5} & $3-5 \mathrm{E}$ & $*$ & $*$ \\
\hline & $4-5 \mathrm{E}$ & $*$ & $*$ \\
\hline & $5-5 \mathrm{E}$ & 6377 & 4367 \\
\hline \multicolumn{4}{|c|}{ LIGANTE 6(82-18-0) } \\
\hline
\end{tabular}

\begin{tabular}{|c|c|c|c|}
\hline Teor (\%) & Corpo-de-prova & $\begin{array}{c}\mathrm{MR}_{\mathrm{T}}-\mathrm{NCHRP} \\
\text { (MPa) }\end{array}$ & $\mathrm{MR}_{\mathrm{T}}-\underset{\text { (cond) }}{\operatorname{NCHRP}(\mathrm{MPa})}$ \\
\hline \multirow{3}{*}{4,5} & $5-6 A$ & 20549 & 7752 \\
\hline & $6-6 \mathrm{~A}$ & 19262 & 9109 \\
\hline & $7-6 \mathrm{~A}$ & 19478 & 9250 \\
\hline \multirow{3}{*}{5,0} & $1-6 \mathrm{~B}$ & 11707 & 6850 \\
\hline & $3-6 \mathrm{~B}$ & 9960 & 7678 \\
\hline & $4-6 \mathrm{~B}$ & 11221 & 6329 \\
\hline \multirow{3}{*}{5,5} & $1-6 \mathrm{C}$ & 14669 & 12266 \\
\hline & $2-6 \mathrm{C}$ & $*$ & $*$ \\
\hline & $5-6 C$ & $*$ & $*$ \\
\hline \multirow{3}{*}{6,0} & $2-6 \mathrm{D}$ & $*$ & $*$ \\
\hline & $5-6 \mathrm{D}$ & $*$ & $*$ \\
\hline & $6-6 \mathrm{D}$ & $*$ & $*$ \\
\hline \multirow{3}{*}{6,5} & $1-6 E$ & $*$ & $*$ \\
\hline & $6-6 \mathrm{E}$ & $*$ & $*$ \\
\hline & $7-6 \mathrm{E}$ & $*$ & $*$ \\
\hline
\end{tabular}

LIGANTE 7(75-18-7)

Teor (\%) Corpo-de-prova $\quad$ MR $_{\mathrm{T}}-\mathrm{NCHRP} \quad \mathrm{MR}_{\mathrm{T}}-\mathrm{NCHRP(MPa)}$

\begin{tabular}{|c|c|c|c|}
\hline \multirow{3}{*}{4,5} & $2-7 \mathrm{~A}$ & 12172 & 6145 \\
\hline & $3-7 \mathrm{~A}$ & 13199 & 7042 \\
\hline & $5-7 \mathrm{~A}$ & 11890 & 6536 \\
\hline \multirow{3}{*}{5,0} & $5-7 \mathrm{~B}$ & $*$ & $*$ \\
\hline & $6-7 \mathrm{~B}$ & 8812 & 6076 \\
\hline & $7-7 B$ & 8941 & 6580 \\
\hline \multirow{3}{*}{5,5} & $1-7 \mathrm{C}$ & $*$ & $*$ \\
\hline & $3-7 \mathrm{C}$ & 8309 & 4872 \\
\hline & $7-7 C$ & 9286 & 5024 \\
\hline \multirow{3}{*}{6,0} & 1-7D & $*$ & $*$ \\
\hline & $3-7 D$ & * & $*$ \\
\hline & $44-7 \mathrm{D}$ & * & * \\
\hline \multirow{3}{*}{6,5} & $2-7 \mathrm{E}$ & $*$ & $*$ \\
\hline & $4-7 \mathrm{E}$ & $*$ & $*$ \\
\hline & $7-7 \mathrm{E}$ & * & $*$ \\
\hline
\end{tabular}


LIGANTE 8(68-18-14)

\begin{tabular}{cccc}
\hline \multirow{2}{*}{ Teor (\%) } & Corpo-de-prova & $\begin{array}{c}\mathbf{M R}_{\mathbf{T}}-\mathbf{N C H R P} \\
\text { (MPa) }\end{array}$ & $\begin{array}{c}\mathbf{M R}_{\mathbf{T}}-\mathbf{N C H R P ( M P a )} \\
\text { (cond) }\end{array}$ \\
\hline \multirow{3}{*}{4,5} & $4-8 \mathrm{~A}$ & 5165 & 1792 \\
\cline { 2 - 4 } & $5-8 \mathrm{~A}$ & 6005 & 3020 \\
\cline { 2 - 4 } 5,0 & $6-8 \mathrm{~A}$ & 6052 & 3138 \\
\cline { 2 - 4 } & $4-8 \mathrm{~B}$ & 4630 & 2154 \\
\cline { 2 - 4 } & $6-8 \mathrm{~B}$ & 4613 & 2726 \\
\hline \multirow{3}{*}{5,5} & $7-8 \mathrm{~B}$ & 4733 & 2411 \\
\cline { 2 - 4 } & $1-8 \mathrm{C}$ & 6368 & 4559 \\
\cline { 2 - 4 } 6,0 & $3-8 \mathrm{C}$ & 6163 & 4709 \\
\cline { 2 - 4 } & $4-8 \mathrm{C}$ & 6642 & 4013 \\
\cline { 2 - 4 } & $2-8 \mathrm{D}$ & 6875 & 4982 \\
\hline \multirow{3}{*}{6,5} & $5-8 \mathrm{D}$ & 6753 & 4027 \\
\cline { 2 - 4 } & $7-8 \mathrm{D}$ & 6084 & 4193 \\
\cline { 2 - 4 } & $2-8 \mathrm{E}$ & 5015 & 4055 \\
\hline
\end{tabular}

Tabela G3: Resistência à tração condicionada das misturas estudadas

\begin{tabular}{|c|c|c|c|c|c|c|c|}
\hline Ligante & $\begin{array}{c}\text { Corpo-de- } \\
\text { prova } \\
\end{array}$ & $\begin{array}{c}\text { Diâmetro } \\
(\mathrm{cm})\end{array}$ & $\begin{array}{c}\text { Altura } \\
(\mathbf{c m})\end{array}$ & Carga (Kg) & $\begin{array}{c}\text { Carga } \\
\text { (N) }\end{array}$ & $\begin{array}{c}\text { RT } \\
(\mathrm{MPa})\end{array}$ & Média RT \\
\hline \multirow{15}{*}{$100-0-0$} & 5-1A & 10,18 & 6,18 & 1864 & 18286 & 1,85 & \\
\hline & $6-1 \mathrm{~A}$ & 10,17 & 6,20 & 2018 & 19797 & 2,00 & 1,90 \\
\hline & $7-1 \mathrm{~A}$ & 10,18 & 6,18 & 1875 & 18394 & 1,86 & \\
\hline & $1-1 \mathrm{~B}$ & 10,15 & 6,17 & 2310 & 22661 & 2,30 & \\
\hline & $3-1 \mathrm{~B}$ & 10,17 & 6,13 & 2345 & 23004 & 2,35 & 2,36 \\
\hline & $4-1 B$ & 10,17 & 6,14 & 2428 & 23819 & 2,43 & \\
\hline & $5-1 \mathrm{C}$ & 10,17 & 6,05 & 3053 & 29950 & 3,10 & \\
\hline & $6-1 \mathrm{C}$ & 10,18 & 5,98 & 2960 & 29038 & 3,04 & 3,09 \\
\hline & $7-1 \mathrm{C}$ & 10,17 & 6,06 & 3081 & 30225 & 3,12 & \\
\hline & $3-1 \mathrm{D}$ & 10,16 & 6,02 & 2972 & 29155 & 3,04 & \\
\hline & 4-1D & 10,16 & 6,01 & 3216 & 31549 & 3,29 & 3,10 \\
\hline & 6-1D & 10,16 & 6,11 & 2945 & 28890 & 2,96 & \\
\hline & $4-1 \mathrm{E}$ & 10,16 & 5,93 & 2766 & 27134 & 2,87 & \\
\hline & $5-1 \mathrm{E}$ & 10,15 & 5,99 & 2832 & 27782 & 2,91 & 2,88 \\
\hline & $6-1 \mathrm{E}$ & 10,16 & 5,87 & 2734 & 26821 & 2,86 & \\
\hline \multirow{8}{*}{ 93-0-7 } & $1-2 \mathrm{~A}$ & 10,19 & 6,02 & 2161 & 21199 & 2,20 & \\
\hline & $3-2 \mathrm{~A}$ & 10,18 & 6,00 & 2230 & 21876 & 2,28 & 2,29 \\
\hline & $4-2 \mathrm{~A}$ & 10,17 & 6,01 & 2326 & 22818 & 2,38 & \\
\hline & $3-2 B$ & 10,17 & 6,03 & 2514 & 24662 & 2,56 & \\
\hline & $4-2 B$ & 10,16 & 6,03 & 2429 & 23828 & 2,48 & 2,48 \\
\hline & $6-2 B$ & 10,17 & 6,00 & 2359 & 23142 & 2,42 & \\
\hline & $1-2 \mathrm{C}$ & 10,17 & 5,98 & $*$ & $*$ & $*$ & \\
\hline & $3-2 C$ & 10,16 & 6,03 & $*$ & $*$ & $*$ & - \\
\hline
\end{tabular}




\begin{tabular}{|c|c|c|c|c|c|c|c|}
\hline & $\begin{array}{c}\text { Corpo-de- } \\
\text { prova }\end{array}$ & $\begin{array}{c}\text { Diâmetro } \\
\text { (cm) }\end{array}$ & $\begin{array}{l}\text { Altura } \\
\text { (cm) }\end{array}$ & Carga (Kg) & $\begin{array}{c}\text { Carga } \\
\text { (N) }\end{array}$ & $\begin{array}{c}\text { RT } \\
\text { (MPa) }\end{array}$ & Média RT \\
\hline & $7-2 \mathrm{C}$ & 10,18 & 5,95 & $*$ & $*$ & $*$ & \\
\hline & $2-2 \mathrm{D}$ & 10,14 & 5,95 & $*$ & $*$ & $*$ & \\
\hline & $5-2 \mathrm{D}$ & 10,15 & 5,93 & $*$ & $*$ & $*$ & - \\
\hline & $6-2 \mathrm{D}$ & 10,16 & 5,90 & $*$ & $*$ & $*$ & \\
\hline & $4-2 \mathrm{E}$ & 10,16 & 5,96 & $*$ & $*$ & $*$ & \\
\hline & $5-2 \mathrm{E}$ & 10,15 & 5,94 & $*$ & $*$ & $*$ & - \\
\hline & $7-2 \mathrm{E}$ & 10,14 & 5,96 & $*$ & $*$ & $*$ & \\
\hline & & & & & & & \\
\hline \multirow{15}{*}{ 86-0-14 } & $1-3 \mathrm{~A}$ & 10,18 & 6,11 & 1168 & 11458 & 1,17 & \\
\hline & $3-3 \mathrm{~A}$ & 10,19 & 6,16 & 1334 & 13087 & 1,33 & 1,24 \\
\hline & $7-3 \mathrm{~A}$ & 10,17 & 6,15 & 1213 & 11900 & 1,21 & \\
\hline & $2-3 \mathrm{~B}$ & 10,18 & 6,04 & 1552 & 15225 & 1,58 & \\
\hline & $4-3 \mathrm{~B}$ & 10,18 & 6,07 & 1499 & 14705 & 1,52 & 1,59 \\
\hline & $5-3 \mathrm{~B}$ & 10,16 & 6,04 & 1636 & 16049 & 1,67 & \\
\hline & $2-3 C$ & 10,16 & 5,96 & $*$ & $*$ & $*$ & \\
\hline & $5-3 \mathrm{C}$ & 10,17 & 5,88 & $*$ & $*$ & $*$ & - \\
\hline & $6-3 \mathrm{C}$ & 10,16 & 5,98 & $*$ & $*$ & $*$ & \\
\hline & $2-3 \mathrm{D}$ & 10,15 & 5,91 & $*$ & $*$ & * & \\
\hline & $4-3 \mathrm{D}$ & 10,15 & 5,90 & $*$ & $*$ & $*$ & - \\
\hline & $7-3 \mathrm{D}$ & 10,17 & 5,89 & $*$ & $*$ & $*$ & \\
\hline & $2-3 \mathrm{E}$ & 10,13 & 6,00 & $*$ & $*$ & $*$ & \\
\hline & $4-3 \mathrm{E}$ & 10,16 & 5,93 & $*$ & $*$ & $*$ & - \\
\hline & $6-3 \mathrm{E}$ & 10,15 & 5,80 & $*$ & $*$ & $*$ & \\
\hline \multirow{15}{*}{ 91-9-0 } & $2-4 \mathrm{~A}$ & 10,18 & 6,20 & 1142 & 11203 & 1,13 & \\
\hline & $3-4 \mathrm{~A}$ & 10,16 & 6,20 & 1161 & 11389 & 1,15 & 1,12 \\
\hline & $7-4 \mathrm{~A}$ & 10,18 & 6,20 & 1085 & 10644 & 1,07 & \\
\hline & $2-4 \mathrm{~B}$ & 10,19 & 6,13 & 1793 & 17589 & 1,79 & \\
\hline & $3-4 \mathrm{~B}$ & 10,17 & 6,11 & 1898 & 18619 & 1,91 & 1,98 \\
\hline & $5-4 \mathrm{~B}$ & 10,18 & 6,04 & 2205 & 21631 & 2,24 & \\
\hline & $2-4 \mathrm{C}$ & 10,17 & 6,04 & 1894 & 18580 & 1,93 & \\
\hline & $3-4 \mathrm{C}$ & 10,17 & 6,10 & 1792 & 17580 & 1,80 & 1,80 \\
\hline & $6-4 \mathrm{C}$ & 10,19 & 6,14 & 1661 & 16294 & 1,66 & \\
\hline & $2-4 \mathrm{D}$ & 10,14 & 5,99 & $*$ & $*$ & $*$ & \\
\hline & $3-4 \mathrm{D}$ & 10,17 & 5,95 & $*$ & $*$ & $*$ & - \\
\hline & $4-4 \mathrm{D}$ & 10,15 & 5,98 & $*$ & $*$ & $*$ & \\
\hline & $2-4 \mathrm{E}$ & 10,17 & 6,04 & $*$ & $*$ & $*$ & \\
\hline & $3-4 \mathrm{E}$ & 10,17 & 6,06 & 2432 & 23858 & 2,47 & 2,34 \\
\hline & $6-4 \mathrm{E}$ & 10,17 & 6,03 & 2171 & 21298 & 2,21 & \\
\hline \multirow{10}{*}{$77-9-14$} & $2-5 \mathrm{~A}$ & 10,16 & 6,12 & 1586 & 15559 & 1,59 & \\
\hline & $4-5 \mathrm{~A}$ & 10,17 & 6,07 & 1673 & 16412 & 1,69 & 1,71 \\
\hline & $5-5 \mathrm{~A}$ & 10,18 & 6,06 & 1805 & 17707 & 1,83 & \\
\hline & $1-5 \mathrm{~B}$ & 10,17 & 6,07 & 1515 & 14862 & 1,53 & \\
\hline & $3-5 \mathrm{~B}$ & 10,18 & 6,03 & 1486 & 14578 & 1,51 & 1,53 \\
\hline & $7-5 B$ & 10,18 & 5,96 & 1490 & 14617 & 1,53 & \\
\hline & $4-5 \mathrm{C}$ & 10,18 & 5,95 & $*$ & $*$ & $*$ & \\
\hline & $5-5 \mathrm{C}$ & 10,17 & 6,02 & 1431 & 14038 & 1,46 & 1,50 \\
\hline & $6-5 \mathrm{C}$ & 10,18 & 5,95 & 1489 & 14607 & 1,54 & \\
\hline & $3-5 \mathrm{D}$ & 10,15 & 5,90 & $*$ & $*$ & $*$ & \\
\hline
\end{tabular}




\begin{tabular}{|c|c|c|c|c|c|c|c|}
\hline & $\begin{array}{c}\text { Corpo-de- } \\
\text { prova }\end{array}$ & $\begin{array}{c}\text { Diâmetro } \\
\text { (cm) }\end{array}$ & $\begin{array}{l}\text { Altura } \\
\text { (cm) }\end{array}$ & Carga (Kg) & $\begin{array}{c}\text { Carga } \\
(\mathrm{N})\end{array}$ & $\begin{array}{c}\text { RT } \\
\text { (MPa) }\end{array}$ & Média RT \\
\hline & $5-5 \mathrm{D}$ & 10,17 & 5,93 & $*$ & $*$ & $*$ & - \\
\hline & $6-5 \mathrm{D}$ & 10,16 & 5,92 & $*$ & $*$ & $*$ & \\
\hline & $3-5 E$ & 10,17 & 5,99 & $*$ & $*$ & $*$ & \\
\hline & $4-5 \mathrm{E}$ & 10,15 & 5,98 & $*$ & $*$ & $*$ & 1,22 \\
\hline & $5-5 \mathrm{E}$ & 10,18 & 6,03 & 1197 & 11743 & 1,22 & \\
\hline \multirow{15}{*}{ 82-18-0 } & $5-6 \mathrm{~A}$ & 10,18 & 6,21 & 1531 & 15019 & 1,51 & \\
\hline & $6-6 \mathrm{~A}$ & 10,17 & 6,22 & 1650 & 16187 & 1,63 & 1,56 \\
\hline & $7-6 \mathrm{~A}$ & 10,16 & 6,20 & 1563 & 15333 & 1,55 & \\
\hline & $1-6 \mathrm{~B}$ & 10,18 & 6,16 & 1559 & 15294 & 1,55 & \\
\hline & $3-6 \mathrm{~B}$ & 10,15 & 6,15 & 1394 & 13675 & 1,40 & 1,43 \\
\hline & $4-6 B$ & 10,19 & 6,30 & 1372 & 13459 & 1,34 & \\
\hline & $1-6 \mathrm{C}$ & 10,16 & 6,19 & 2249 & 22063 & 2,23 & \\
\hline & $2-6 \mathrm{C}$ & 10,16 & 6,18 & $*$ & $*$ & $*$ & 2,23 \\
\hline & $5-6 \mathrm{C}$ & 10,18 & 6,03 & $*$ & $*$ & $*$ & \\
\hline & $2-6 \mathrm{D}$ & 10,17 & 5,99 & $*$ & $*$ & $*$ & \\
\hline & $5-6 \mathrm{D}$ & 10,15 & 6,07 & $*$ & $*$ & $*$ & - \\
\hline & $6-6 \mathrm{D}$ & 10,16 & 6,15 & $*$ & $*$ & $*$ & \\
\hline & $1-6 \mathrm{E}$ & 10,17 & 6,07 & $*$ & $*$ & $*$ & \\
\hline & $6-6 \mathrm{E}$ & 10,19 & 6,08 & $*$ & $*$ & $*$ & - \\
\hline & $7-6 \mathrm{E}$ & 10,17 & 6,09 & $*$ & $*$ & $*$ & \\
\hline \multirow{15}{*}{$75-18-7$} & $2-7 \mathrm{~A}$ & 10,19 & 6,18 & 1455 & 14274 & 1,44 & \\
\hline & $3-7 \mathrm{~A}$ & 10,18 & 6,12 & 1493 & 14646 & 1,50 & 1,49 \\
\hline & $5-7 \mathrm{~A}$ & 10,18 & 6,17 & 1530 & 15009 & 1,52 & \\
\hline & $5-7 \mathrm{~B}$ & 10,19 & 6,02 & $*$ & $*$ & $*$ & \\
\hline & $6-7 \mathrm{~B}$ & 10,17 & 6,12 & 1552 & 15225 & 1,56 & 1,60 \\
\hline & $7-7 \mathrm{~B}$ & 10,18 & 6,10 & 1624 & 15931 & 1,63 & \\
\hline & $1-7 \mathrm{C}$ & 10,17 & 6,10 & $*$ & $*$ & $*$ & \\
\hline & $3-7 \mathrm{C}$ & 10,16 & 6,14 & 1403 & 13763 & 1,41 & 1,38 \\
\hline & $7-7 \mathrm{C}$ & 10,18 & 6,10 & 1338 & 13126 & 1,35 & \\
\hline & $1-7 \mathrm{D}$ & 10,16 & 6,05 & $*$ & $*$ & $*$ & \\
\hline & 3-7D & 10,17 & 5,96 & $*$ & $*$ & $*$ & - \\
\hline & $4-7 \mathrm{D}$ & 10,17 & 6,06 & $*$ & $*$ & $*$ & \\
\hline & $2-7 \mathrm{E}$ & 10,17 & 6,05 & $*$ & $*$ & $*$ & \\
\hline & 4-7E & 10,15 & 6,03 & $*$ & $*$ & $*$ & - \\
\hline & $7-7 \mathrm{E}$ & 10,15 & 6,08 & $*$ & $*$ & $*$ & \\
\hline \multirow{13}{*}{ 68-18-14 } & $4-8 \mathrm{~A}$ & 10,17 & 6,28 & 597 & 5857 & 0,58 & \\
\hline & $5-8 \mathrm{~A}$ & 10,18 & 6,24 & 675 & 6622 & 0,66 & 0,65 \\
\hline & $6-8 \mathrm{~A}$ & 10,18 & 6,25 & 711 & 6975 & 0,70 & \\
\hline & $4-8 \mathrm{~B}$ & 10,19 & 6,26 & 665 & 6524 & 0,65 & \\
\hline & $6-8 \mathrm{~B}$ & 10,17 & 6,30 & 684 & 6710 & 0,67 & 0,66 \\
\hline & $7-8 \mathrm{~B}$ & 10,18 & 6,30 & 693 & 6798 & 0,68 & \\
\hline & $1-8 \mathrm{C}$ & 10,17 & 6,13 & 1154 & 11321 & 1,16 & \\
\hline & $3-8 \mathrm{C}$ & 10,18 & 6,12 & 1085 & 10644 & 1,09 & 1,12 \\
\hline & $4-8 \mathrm{C}$ & 10,18 & 6,11 & 1113 & 10919 & 1,12 & \\
\hline & $2-8 \mathrm{D}$ & 10,17 & 6,09 & 1259 & 12351 & 1,27 & \\
\hline & $5-8 \mathrm{D}$ & 10,17 & 6,12 & 1169 & 11468 & 1,17 & 1,19 \\
\hline & $7-8 \mathrm{D}$ & 10,16 & 6,20 & 1150 & 11282 & 1,14 & \\
\hline & $2-8 \mathrm{E}$ & 10,16 & 6,08 & 1212 & 11890 & 1,23 & \\
\hline
\end{tabular}




\begin{tabular}{c|c|c|c|c|c|c|c}
\hline & $\begin{array}{c}\text { Corpo-de- } \\
\text { prova }\end{array}$ & $\begin{array}{c}\text { Diâmetro } \\
\mathbf{( c m )}\end{array}$ & $\begin{array}{c}\text { Altura } \\
\mathbf{( c m )}\end{array}$ & Carga (Kg) & $\begin{array}{c}\text { Carga } \\
\mathbf{( N )}\end{array}$ & $\begin{array}{c}\text { RT } \\
\text { (MPa) }\end{array}$ & Média RT \\
\cline { 2 - 7 } & $3-8 \mathrm{E}$ & 10,17 & 6,16 & 1175 & 11527 & 1,17 & $\mathbf{1 , 2 2}$ \\
\hline & $4-8 \mathrm{E}$ & 10,15 & 6,15 & 1258 & 12341 & 1,26 & \\
\hline
\end{tabular}

Tabela G4: Relação da resistência à tração condicionada das misturas estudadas

\begin{tabular}{|c|c|c|c|c|c|c|}
\hline $\begin{array}{l}\text { Teor } \\
\text { (\%) }\end{array}$ & Ligante & $\begin{array}{c}\text { RT (cond) } \\
\text { (MPa) }\end{array}$ & $\begin{array}{c}\text { RT } \\
\text { (cond) } \\
\text { Média }\end{array}$ & $\begin{array}{c}\text { RT } \\
\text { (MPa) }\end{array}$ & $\begin{array}{c}\text { RRT } \\
\text { (\%) }\end{array}$ & $\begin{array}{l}\text { RRT (\%) } \\
\text { médio }\end{array}$ \\
\hline \multirow{24}{*}{4,5} & \multirow{3}{*}{$(100-0-0)$} & 1,85 & & & & \\
\hline & & 2,00 & 1,90 & 2,58 & 73,82 & 73,82 \\
\hline & & 1,86 & & & & \\
\hline & \multirow{3}{*}{$(93-0-7)$} & 2,20 & & & & \\
\hline & & 2,28 & 2,29 & 2,21 & 103,47 & 103,47 \\
\hline & & 2,38 & & & & \\
\hline & \multirow{3}{*}{$(86-0-14)$} & 1,17 & & & & \\
\hline & & 1,33 & 1,24 & 1,48 & 83,63 & 83,63 \\
\hline & & 1,21 & & & & \\
\hline & \multirow{3}{*}{$(91-9-0)$} & 1,13 & & & & \\
\hline & & 1,15 & 1,12 & 1,86 & 60,15 & 60,15 \\
\hline & & 1,07 & & & & \\
\hline & \multirow{3}{*}{$(77-9-14)$} & 1,59 & & & & \\
\hline & & 1,69 & 1,71 & 1,93 & 88,35 & 88,35 \\
\hline & & 1,83 & & & & \\
\hline & \multirow{3}{*}{$(82-18-0)$} & 1,51 & & & & \\
\hline & & 1,63 & 1,56 & 2,18 & 71,77 & 71,77 \\
\hline & & 1,55 & & & & \\
\hline & \multirow{3}{*}{$(75-18-7)$} & 1,44 & & & & \\
\hline & & 1,50 & 1,49 & 2,03 & 73,29 & 73,29 \\
\hline & & 1,52 & & & & \\
\hline & \multirow{3}{*}{$(68-18-14)$} & 0,58 & & & & \\
\hline & & 0,66 & 0,65 & 1,03 & 62,99 & 62,99 \\
\hline & & 0,70 & & & & \\
\hline \multirow{13}{*}{5,0} & \multirow{3}{*}{$(100-0-0)$} & 2,30 & & & & \\
\hline & & 2,35 & 2,36 & 2,66 & 88,78 & 88,78 \\
\hline & & 2,43 & & & & \\
\hline & \multirow{3}{*}{$(93-0-7)$} & 2,56 & & & & \\
\hline & & 2,48 & 2,48 & 2,59 & 95,94 & 95,94 \\
\hline & & 2,42 & & & & \\
\hline & \multirow{3}{*}{$(86-0-14)$} & 1,58 & & & & \\
\hline & & 1,52 & 1,59 & 1,62 & 97,92 & 97,92 \\
\hline & & 1,67 & & & & \\
\hline & \multirow{3}{*}{$(91-9-0)$} & 1,79 & & & & \\
\hline & & 1,91 & 1,98 & 2,39 & 82,89 & 82,89 \\
\hline & & 2,24 & & & & \\
\hline & $(77-9-14)$ & 1,53 & & & & \\
\hline
\end{tabular}




\begin{tabular}{|c|c|c|c|c|c|c|}
\hline & & 1,51 & 1,53 & 1,92 & 79,52 & 79,52 \\
\hline & & 1,53 & & & & \\
\hline & \multirow{3}{*}{$(82-18-0)$} & 1,55 & & & & \\
\hline & & 1,40 & 1,43 & 2,01 & 71,05 & 71,05 \\
\hline & & 1,34 & & & & \\
\hline & Ligante & $\begin{array}{c}\text { RT (cond) } \\
\text { (MPa) }\end{array}$ & $\begin{array}{c}\text { RT } \\
\text { (cond) } \\
\text { Média }\end{array}$ & $\begin{array}{c}\text { RT } \\
\text { (MPa) }\end{array}$ & $\begin{array}{c}\text { RRT } \\
(\%)\end{array}$ & $\begin{array}{c}\text { RRT (\%) } \\
\text { médio }\end{array}$ \\
\hline & \multirow{3}{*}{$(75-18-7)$} & $*$ & & $*$ & $*$ & \\
\hline & & 1,56 & 1,60 & 2,28 & 70,00 & 70,00 \\
\hline & & 1,63 & & & & \\
\hline & \multirow{3}{*}{$(68-18-14)$} & 0,65 & & & & \\
\hline & & 0,67 & 0,66 & 1,12 & 59,33 & 59,33 \\
\hline & & 0,68 & & & & \\
\hline \multirow{24}{*}{5,5} & \multirow{3}{*}{$(100-0-0)$} & 3,10 & & & & \\
\hline & & 3,04 & 3,09 & 3,04 & 101,56 & 101,56 \\
\hline & & 3,12 & & & & \\
\hline & & $*$ & & $*$ & $*$ & \\
\hline & $(93-0-7)$ & $*$ & \#DIV/0! & $*$ & $*$ & * \\
\hline & & $*$ & & $*$ & $*$ & \\
\hline & & $*$ & & $*$ & * & \\
\hline & $(86-0-14)$ & $*$ & \#DIV/0! & $*$ & $*$ & $*$ \\
\hline & & $*$ & & $*$ & $*$ & \\
\hline & & $*$ & & $*$ & $*$ & \\
\hline & $(91-9-0)$ & 1,46 & 1,50 & 1,83 & 81,87 & 81,87 \\
\hline & & 1,54 & & & & \\
\hline & & 1,53 & & & & \\
\hline & $(77-9-14)$ & 1,51 & 1,53 & 1,92 & 79,52 & 79,52 \\
\hline & & 1,53 & & & & \\
\hline & & 2,23 & & & & \\
\hline & $(82-18-0)$ & $*$ & 2,23 & 2,59 & 86,27 & 86,27 \\
\hline & & $*$ & & $*$ & $*$ & \\
\hline & & $*$ & & $*$ & $*$ & \\
\hline & $(75-18-7)$ & 1,41 & 1,38 & 1,98 & 69,48 & 69,48 \\
\hline & & 1,35 & & & & \\
\hline & & 0,65 & & & & \\
\hline & $(68-18-14)$ & 0,67 & 0,66 & 1,12 & 59,33 & 59,33 \\
\hline & & 0,68 & & & & \\
\hline & & 2,87 & & & & \\
\hline & $(100-0-0)$ & 2,91 & 2,88 & 2,66 & 108,32 & 108,32 \\
\hline & & 2,86 & & & & \\
\hline 60 & & $*$ & & $*$ & $*$ & \\
\hline 0,0 & $(93-0-7)$ & $*$ & $*$ & $*$ & $*$ & $*$ \\
\hline & $(95-0-1)$ & $*$ & & * & $*$ & \\
\hline
\end{tabular}




\begin{tabular}{|c|c|c|c|c|c|c|}
\hline & Ligante & $\begin{array}{c}\text { RT (cond) } \\
\text { (MPa) }\end{array}$ & $\begin{array}{c}\text { RT } \\
\text { (cond) } \\
\text { Média } \\
\end{array}$ & $\begin{array}{c}\text { RT } \\
\text { (MPa) }\end{array}$ & $\begin{array}{c}\text { RRT } \\
(\%)\end{array}$ & $\begin{array}{c}\text { RRT (\%) } \\
\text { médio }\end{array}$ \\
\hline & \multirow{4}{*}{$(86-0-14)$} & $*$ & & $*$ & $*$ & \\
\hline & & & & & & \\
\hline & & $*$ & $*$ & $*$ & $*$ & $*$ \\
\hline & & $*$ & & $*$ & * & \\
\hline & \multirow{3}{*}{$(91-9-0)$} & $*$ & & $*$ & $*$ & \\
\hline & & $*$ & $*$ & $*$ & $*$ & $*$ \\
\hline & & $*$ & & $*$ & * & \\
\hline & \multirow{4}{*}{$(77-9-14)$} & $*$ & & $*$ & $*$ & \\
\hline & & & & & & \\
\hline & & $*$ & $*$ & $*$ & $*$ & $*$ \\
\hline & & $*$ & & $*$ & $*$ & \\
\hline & \multirow{3}{*}{$(82-18-0)$} & $*$ & & $*$ & $*$ & \\
\hline & & $*$ & $*$ & $*$ & $*$ & $*$ \\
\hline & & $*$ & & $*$ & $*$ & \\
\hline & \multirow{3}{*}{$(75-18-7)$} & $*$ & & $*$ & $*$ & \\
\hline & & $*$ & $*$ & $*$ & $*$ & $*$ \\
\hline & & $*$ & & $*$ & $*$ & \\
\hline & \multirow{3}{*}{$(68-18-14)$} & 1,27 & & & & \\
\hline & & 1,17 & 1,19 & 1,42 & 84,14 & 84,14 \\
\hline & & 1,14 & & & & \\
\hline \multirow{24}{*}{6,5} & \multirow{3}{*}{$(100-0-0)$} & 3,04 & & & & \\
\hline & & 3,29 & 3,10 & 3,02 & 102,55 & 102,55 \\
\hline & & 2,96 & & & & \\
\hline & \multirow{3}{*}{$(93-0-7)$} & $*$ & & $*$ & $*$ & \\
\hline & & $*$ & $*$ & $*$ & $*$ & $*$ \\
\hline & & $*$ & & $*$ & $*$ & \\
\hline & \multirow{3}{*}{$(86-0-14)$} & $*$ & & $*$ & $*$ & \\
\hline & & $*$ & $*$ & $*$ & $*$ & $*$ \\
\hline & & $*$ & & $*$ & $*$ & \\
\hline & \multirow{3}{*}{$(91-9-0)$} & $*$ & & $*$ & $*$ & \\
\hline & & 2,47 & 2,34 & 2,45 & 95,46 & 95,46 \\
\hline & & 2,21 & & & & \\
\hline & \multirow{3}{*}{$(77-9-14)$} & $*$ & & $*$ & $*$ & \\
\hline & & $*$ & 1,22 & $*$ & 73,84 & 73,84 \\
\hline & & 1,22 & & 1,65 & & \\
\hline & \multirow{3}{*}{$(82-18-0)$} & $*$ & & $*$ & $*$ & \\
\hline & & $*$ & $*$ & $*$ & $*$ & * \\
\hline & & $*$ & & $*$ & $*$ & \\
\hline & \multirow{3}{*}{$(75-18-7)$} & $*$ & & $*$ & $*$ & \\
\hline & & $*$ & $*$ & $*$ & $*$ & $*$ \\
\hline & & $*$ & & $*$ & $*$ & \\
\hline & \multirow{3}{*}{$(68-18-14)$} & 1,23 & & & & \\
\hline & & 1,17 & 1,22 & 1,22 & 99,92 & 99,92 \\
\hline & & 1,26 & & & & \\
\hline
\end{tabular}


